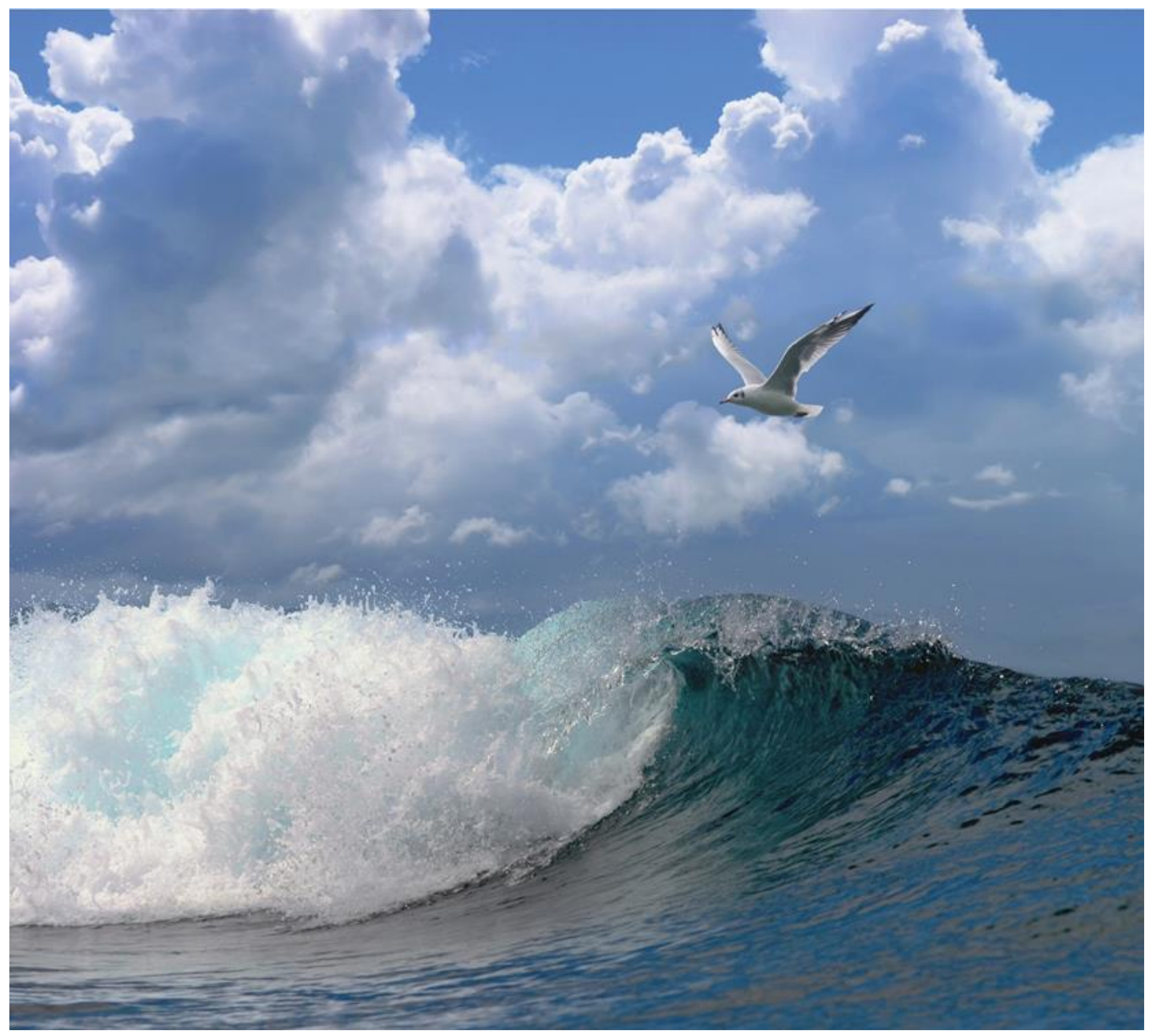

Cumulative population-level effects of habitat loss on seabirds 'Kader Ecologie en Cumulatie 4.0' 


\section{Cumulative population-level effects of habitat loss on seabirds 'Kader Ecologie en Cumulatie 4.0'}

Author(s): F.H. Soudijn, V. Hin, J.T. van der Wal, S. van Donk

Wageningen Marine Research 
Keywords: habitat loss, seabirds, KEC, population effects, ALI

Client: $\quad$ Rijkswaterstaat Water, Verkeer en Leefomgeving

Attn.: K. Portegies

Lange Kleiweg 34

2288GK Rijswijk

This report can be downloaded for free from https://doi.org/10.18174/553775

Wageningen Marine Research provides no printed copies of reports

Wageningen Marine Research is ISO 9001:2015 certified.

\section{(C) Wageningen Marine Research}

Wageningen Marine Research, an institute within the legal entity Stichting Wageningen Research (a foundation under Dutch private law) represented by

Drs.ir. M.T. van Manen, Director Operations

KvK nr. 09098104,

WMR BTW nr. NL 8113.83.696.B16.

Code BIC/SWIFT address: RABONL2U

IBAN code: NL 73 RABO 0373599285
Wageningen Marine Research accepts no liability for consequential damage, nor for damage resulting from applications of the results of work or other data obtained from Wageningen Marine Research. Client indemnifies Wageningen Marine Research from claims of third parties in connection with this application.

All rights reserved. No part of this publication may be reproduced and / or published, photocopied or used in any other way without the written permission of the publisher or author.

A_4_3_2 V31 (2021) 


\section{Contents}

$\begin{array}{lr}\text { Summary } & \mathbf{5}\end{array}$

1 Introduction $\quad 6$

$2 \quad$ Study outline $\quad 7$

2.1.1 Bird dot and density maps $\quad 7$

2.1.2 Population models $\quad 8$

2.1.3 Habitat loss mortality per scenario $\quad 8$

$\begin{array}{ll}\text { 2.1.4 Population-level effects } & 9\end{array}$

$3 \quad$ Materials and Methods $r$

$\begin{array}{lll}3.1 & \text { Data preparation } & 10\end{array}$

$\begin{array}{ll}3.1 .1 & \text { Data sources }\end{array}$

$\begin{array}{ll}3.1 .2 & \text { Data selection }\end{array}$

3.1.3 Distance sampling 13

3.1.4 Count methods \& species counted 13

3.2 Density maps and dot maps 14

3.2.1 Dot maps 14

3.2.2 Density maps 14

3.3 Casualties per wind farm area $\quad 15$

$\begin{array}{lll}3.4 & \text { Mortality calculation } & 17\end{array}$

$\begin{array}{lll}3.5 & \text { Matrix population models } & 17\end{array}$

$\begin{array}{ll}\text { 3.5.1 General model structure } & 18\end{array}$

3.5.2 Habitat loss mortality per life stage $\quad 19$

3.6 Population level effects and acceptable levels of impacts 19

$4 \quad$ Results

4.1 Population level effects $\quad 21$

4.2 Habitat loss casualties $\quad 22$

4.2.1 Casualties per OWF area $\quad 22$

4.2.2 Casualties and mortality estimates per scenario $\quad 28$

4.3 Diver sp. (Gavia sp.) $\quad 29$

4.3.1 Diver sp. habitat loss casualties and mortality 29

$\begin{array}{lll}\text { 4.3.2 Diver sp. population level effects } & 30\end{array}$

4.4 Northern fulmar (Fulmarus glacialis) 32

4.4.1 Northern fulmar habitat loss casualties and mortality 32

4.4.2 Northern fulmar population level effects 33

$\begin{array}{lll}4.5 & \text { Northern gannet (Morus bassanus) } & 35\end{array}$

4.5.1 Northern gannet habitat loss casualties and mortality $\quad 35$

4.5.2 Northern gannet population level effects 38

$\begin{array}{lll}4.6 & \text { Great cormorant (Phalacrocorax carbo) } & 39\end{array}$

4.6.1 Great cormorant habitat loss casualties and mortality 39

4.7 Common eider (Somateria mollissima) 41

4.7.1 Common eider habitat loss casualties and mortality $\quad 41$

4.8 Common scoter (Melanitta nigra) 42

4.8.1 Common scoter habitat loss casualties and mortality $\quad 42$

4.9 Sandwich tern (Thalasseus sandvicensis) $\quad 44$

4.9.1 Sandwich tern habitat loss casualties and mortality 44

$\begin{array}{lll}4.9 .2 & \text { Sandwich tern population level effects } & 47\end{array}$

\begin{tabular}{ll}
4.10 & Common guillemot (Uria aalge) \\
\hline
\end{tabular} 
4.10.1 Common guillemot habitat loss casualties and mortality 48

4.10.2 Common guillemot population-level effects $\quad 51$

4.11 Razorbill (Alca torda)

4.11.1 Razorbill habitat loss casualties and mortality 52

4.11.2 Razorbill population level effects $\quad 53$

4.12 Atlantic puffin (Fratercula arctica)

4.12.1 Atlantic puffin habitat loss casualties and mortality $\quad 54$

4.12.2 Atlantic puffin population level effects $\quad 57$

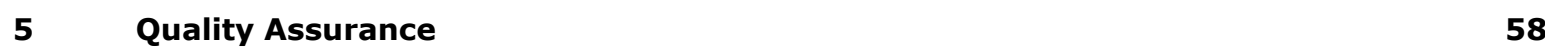

$\begin{array}{lr}\text { References } & 59\end{array}$

$\begin{array}{lr}\text { Justification } & 65\end{array}$

$\begin{array}{llr}\text { Annex } 1 & \text { Population models } & 66\end{array}$

Diver sp. (Gavia sp.) $\quad 66$

$\begin{array}{ll}\text { Northern gannet (Morus bassanus) } & 67\end{array}$

$\begin{array}{ll}\text { Sandwich tern (Thalasseus sandvicensis) } & 68\end{array}$

Razorbill (Alca torda) $\quad 69$

$\begin{array}{ll}\text { Common guillemot (Uria aalge) } & 70\end{array}$

Northern fulmar (Fulmarus glacialis)

Atlantic puffin (Fratercula arctica)

$\begin{array}{lll}\text { Annex } 2 & \text { Number of casualties for Dutch OWF areas } & 75\end{array}$ 


\section{Summary}

In the programme 'Programma Noordzee 2022-2027', new areas at sea will be appointed as development areas for wind energy. An assessment was made of the effect of habitat loss due to the potential new offshore wind farms on seabirds, the diver spec., the northern fulmar, the great cormorant, the common eider, the common scoter, the common guillemot, the razorbill and the Atlantic puffin. For the great cormorant, the common eider and the common scoter, the effects of habitat loss were assessed based on estimated numbers of casualties. For the other species, population models were used to assess the effect of habitat loss on the population level. For the northern gannet and the sandwich tern, both the effects of habitat loss as well as the effects of collision mortality were tested together in the population models. Here, the method and calculation of the numbers of casualties due to habitat loss are described. The estimation of the numbers of casualties due to collision mortality were described by Potiek et al. (2021a). The population effects of offshore wind farms on seabirds were considered within six different scenarios:

- $\quad$ No offshore wind farms

- $\quad$ All offshore wind farms planned up to 2030

- $\quad$ 'Rekenvariant I' (+10.7 GW)

- $\quad$ 'Rekenvariant II' (+12.7 GW)

- $\quad$ 'Rekenvariant III' (+16.7 GW)

- International wind farms and Rekenvariant III

The assessment of the effect of offshore wind farms on the ten seabird species considered here consisted of the following steps:

1. Data preparation of seabird observations at sea.

2. Calculation of density and dot maps for the seabird species, the choice of map type depends on the data availability.

3. Calculation of the number of casualties due to habitat loss based on the overlap between the bird maps and the wind farm development areas.

4. Development of two new population models and an update of the life history parameters of the other five population models

5. Calculation of annual mortality probabilities due to habitat loss for all species.

6. Test of the population level effects of annual mortality due to habitat loss and collision mortality for the northern gannet and the sandwich tern and habitat loss only for the other species. Population level effects were tested against the Acceptable Level of Impact (ALI) thresholds (Potiek et al. 2021a) of which values were defined in a working document by LNV.

For the great cormorant, the common eider and the common scoter, the effects of habitat loss of the new national wind farm areas seem negligible as the number of casualties does not increase for the scenarios with new OWF areas compared to the scenario with the OWFs that are already planned. The estimated total annual numbers of casualties for the great cormorant, the common eider and the common scoter were respectively 3.3,4.3 and 7.1 for the national scenarios (Table 12). Most habitat loss casualties in the national scenarios were predicted for the common guillemot (annual totals of 588.4-1418.6) and the razorbill (annual totals of 165-371.9), followed by the northern fulmar (annual totals of 11.6-33.1). For the seven species for which population models were used, no ALI thresholds were violated due to habitat loss casualties. The population dynamics of the razorbills and common guillemots were predicted to be most negatively affected by habitat loss. 


\section{Introduction}

Offshore wind farms (OWF) form an important part of the Dutch strategy to comply with the agreements on reducing $\mathrm{CO}_{2}$ emissions, such as defined in the Paris Agreement. In the programme 'Programma Noordzee 2022-2027', new areas at sea will be appointed as development areas for wind energy (about $27 \mathrm{GW}$ ). These areas will be used for the purpose of the government plan 'routekaart 2040'. There is a need for the assessment of the cumulative ecological effects on seabirds of the development of wind energy in these areas following the framework 'Kader Ecologie en Cumulatie' (KEC), such as previously described by Leopold et al. (KEC 2.0, 2014) and Van der Wal et al. (KEC $3.0,2018$ ). Within KEC, the cumulative effects of wind farms are assessed on species with a protected status in nature legislation. The assessment entails existing as well as suggested future wind farms.

The main adverse effects of offshore wind farms on seabirds are thought to stem from mortality due to collisions with turbines and displacement from wind farm areas, which may lead to a loss of foraging habitat or barriers to both daily and seasonal movements of birds (Drewitt \& Langston, 2006; Masden et al., 2010). Here, the focus lies on potential adverse effects of wind farms on seabirds in relation to displacement and habitat loss. Another part of KEC 4.0 focuses on the effects of collision mortality. The potential adverse effects of wind farms as barriers to movement are not under consideration within KEC. The species that are assessed for the effects of collision mortality and displacement were chosen based on previous studies of avoidance behaviour and flight altitudes of seabirds (e.g. Dierschke et al., 2016) and expert elicitation regarding the potential locations of the future wind farms. Species that show high avoidance are thought to be more sensitive to displacement and habitat loss, while the species that show low avoidance and typically fly at altitudes within the rotor areas of the turbines are thought to be more sensitive to collision mortality. In the current assessment, the sandwich tern and the northern gannet are assessed for potential adverse effects of both factors.

In the previous assessments the cumulative population-level effects were tested against speciesspecific Potential Biological Removal (PBR) reference points. The PBR approach was criticized because it implies a fixed level of density dependence in the populations that leads to compensation of mortality which may not actually occur (O'Brien et al., 2017). Thresholds based on actual population models that explicitly consider the population dynamics of species are considered more reliable (Potiek et al., 2019). Therefore, thresholds were developed, in the form of Acceptable Levels of Impacts (ALIs) that are based on Leslie Matrix population models (Potiek et al., 2021). The current KEC assessment will test the population-level effects of offshore wind farms on seabirds against the species-specific ALI values defined by LNV in a working document. All other steps in the assessment follow the methodology previously described by Leopold et al. (KEC 2.0, 2014) and Van der Wal et al. (KEC 3.0, 2018). 


\section{Study outline}

The study focuses on the assessment of the effects of habitat loss on ten seabird species (Table 1). This memo describes four parts of the study:

a. The dot and density maps for the seabirds that are assessed for the effects of habitat loss and, in addition, collision mortality;

b. The population models for seven of the ten specie, of which two were newly developed;

c. The estimated numbers of casualties of habitat loss per offshore wind farm;

d. The estimated population level effects of habitat loss for five of the ten species. The estimated population level effects of habitat loss and collision mortality for two species, the sandwich tern and the northern gannet.

Each step is described in more detail in the following paragraphs.

\subsubsection{Bird dot and density maps}

Data from the ESAS and MWTL databases were used to create bird dot and density maps for the species under assessment for habitat loss (Table 1) and collision mortality (Table 2). The density maps were created based on the methodology previously described by Leopold et al. (2014) and Van der Wal et al. (2018). Dot maps were created for all species for which the available data were insufficient for full coverage density maps. Note that the northern gannet and sandwich tern were included in both tables as they were assessed for the effects of both habitat loss and collision mortality.

Table 1. Data of the seabird species that are under evaluation for habitat loss, including EUring, names and type of density map (*, dot map; 0, basic density map, 1, density map with medium spreading of data over an area of $5 \times 5$ grid cells, or $625 \mathrm{~km}^{2} ; 2$, density map with medium spreading of data over an area of $11 \times 11$ grid cells, or $3025 \mathrm{~km}^{2}$ ).

\begin{tabular}{|c|c|c|c|c|c|}
\hline EUring & Scientific Name & NL name & EN name & Type & Population model \\
\hline 59 & Gavia sp. & Duiker spec. & Diver sp. & 0 & $\begin{array}{l}\text { (Van Kooten et al., } \\
\text { 2019) }\end{array}$ \\
\hline 220 & Fulmarus glacialis & Noordse stormvogel & Northern fulmar & 1 & This study \\
\hline 710 & Morus bassanus & Jan-van-gent & Northern gannet & 1 & $\begin{array}{l}\text { (Van Kooten et al., } \\
\text { 2019) }\end{array}$ \\
\hline 720 & Phalacrocorax carbo & Aalscholver & Great cormorant & 0 & - \\
\hline 2060 & Somateria mollissima & Eider & Common eider & 0 & - \\
\hline 2130 & Melanitta nigra & Zwarte Zeeëend & Common scoter & 0 & - \\
\hline 6110 & Thalasseus sandvicensis & Grote stern & Sandwich tern & 0 & $\begin{array}{l}\text { (Van Kooten et al., } \\
\text { 2019) }\end{array}$ \\
\hline 6340 & Uria aalge & Zeekoet & Common guillemot & 0 & $\begin{array}{l}\text { (Van Kooten et al., } \\
\text { 2019) }\end{array}$ \\
\hline 6360 & Alca torda & Alk & Razorbill & 0 & $\begin{array}{l}\text { (Van Kooten et al., } \\
\text { 2019) }\end{array}$ \\
\hline 6540 & Fratercula arctica & Papegaaiduiker & Atlantic puffin & 0 & This study \\
\hline
\end{tabular}


Table 2. Data of the seabird species that are under evaluation for collision mortality, including EUring, names and type of density map (*, dot map; 0, basic density map, 1, density map with medium spreading of data over an area of $5 \times 5$ grid cells, or $625 \mathrm{~km}^{2} ; 2$, density map with medium spreading of data over an area of $11 \times 11$ grid cells, or $3025 \mathrm{~km}^{2}$ ).

\begin{tabular}{|c|c|c|c|c|}
\hline Euring & Scientific Name & NL name & EN name & Type \\
\hline 710 & Morus bassanus & Jan-van-gent & Northern gannet & 1 \\
\hline 800 & Phalacrocorax aristotelis & Kuifaalscholver & European shag & $*$ \\
\hline 1530 & Cygnus columbianus & Kleine zwaan & Tundra swan & $*$ \\
\hline 1680 & Branta bernicla & Rotgans & Brent goose & $*$ \\
\hline 1730 & Tadorna tadorna & Bergeend & Shelduck & $*$ \\
\hline 4960 & Calidris canutus & Kanoet & Red knot & $*$ \\
\hline 5320 & Limosa limosa & Grutto & Black-tailed godwit & $*$ \\
\hline 5340 & Limosa lapponica & Rosse grutto & Bar-tailed godwit & $*$ \\
\hline 5410 & Numenius arquata & Wulp & Eurasian curlew & $*$ \\
\hline 6270 & Chlidonias niger & Zwarte stern & Black tern & $*$ \\
\hline 15820 & Sturnus vulgaris & Spreeuw & Common starling & $0 *$ \\
\hline 5670 & Stercorarius parasiticus & Kleine Jager & Arctic skua & 0 \\
\hline 5690 & Stercorarius skua & Grote jager & Great skua & 0 \\
\hline 5780 & Hydrocoloeus minutus & Dwergmeeuw & Little gull & 0 \\
\hline 6110 & Thalasseus sandvicensis & Grote stern & Sandwich tern & 0 \\
\hline 6169 & Sterna paradisaea+hirundo & 'Noordse dief' & 'Commic tern' & 0 \\
\hline 6020 & Rissa tridactyla & Drieteenmeeuw & Kittiwake & 1 \\
\hline 5910 & Larus fuscus & Kleine Mantelmeeuw & Lesser Black-backed gull & 2 \\
\hline 5920 & Larus argentatus & Zilvermeeuw & European herring gull & 2 \\
\hline 6000 & Larus marinus & Grote Mantelmeeuw & Greater Black-backed gull & 2 \\
\hline
\end{tabular}

0* for 15820 , Sturnus vulgaris, both a dot map and a density map were made.

\subsubsection{Population models}

For two out of the ten species, the northern fulmar and the Atlantic puffin, which were assessed for the effect of habitat loss, population models were developed (Table 1). These models have the same structure as the population models previously described by Van Kooten et al. (2019). For five of the ten species that were assessed, population models were taken from the study described by Van Kooten et al. (2019). These five models were updated with the most recently published values for breeding success and survival. Because the remaining three species, the great cormorant, common eider and common scoter, are more restricted to the coast, no population models were developed; little overlap is to be expected between these species' distributions and the Dutch (plans for) offshore wind farms.

\subsubsection{Habitat loss mortality per scenario}

For all ten species, casualties of habitat loss for seabirds were calculated per bimonthly period and OWF area, based on the same assumptions and calculations as the previous assessments described by Van der Wal et al. (KEC 3.0, 2018) and Leopold et al. (KEC 2.0, 2014). Annual mortalities per scenario (Table 3 and Figure 4) were calculated based on the casualties and estimated population sizes (from the density maps) for the seven species for which population models were available.

This study covers four different scenarios for the Dutch EEZ: a basic or base scenario, including operational, under construction, pre-construction and/or authorised OWF for a state of affairs and three other scenarios representing different ambitions that can be aimed for ca. 2030. These scenarios were delivered to WMR by the client (RWS). 
Table 3. Scenario names and wind farms included per scenario

\begin{tabular}{ll} 
Scenario name & Included wind farms \\
Null & No wind farms \\
\hline basic 2030 & existing and permitted wind farms up to $2030(10.8 \mathrm{GW})$ \\
\hline 'Rekenvariant III' & basic $+16.7 \mathrm{GW}$ \\
\hline 'Rekenvariant II' & basic $+12.7 \mathrm{GW}$ \\
\hline 'Rekenvariant I' & basic $+10.7 \mathrm{GW}$ \\
\hline International & existing and expected international farms up to 2030, national \\
& Rekenvariant III scenario included \\
\hline
\end{tabular}

\subsubsection{Population-level effects}

The population-level effects of habitat loss were assessed with species specific population models for five species (Table 1). For two species, the sandwich tern and the northern gannet, the populationlevel effects of both habitat loss and collision mortality were assessed with population models. The collision mortalities that were used for the northern gannet and the sandwich tern were calculated by Potiek et al. (2021b). Using the models, the population growth rates without OWF were compared to the population growth rates with the additional mortality due to OWF. The changes in population growth rates for all seven species were then tested against Acceptable Levels of Impact (ALIs) (Potiek et al., 2021) for which values were defined in a LNV working document. We report whether the estimated additional mortality due to OWFs leads to an exceedance of the ALIs for any of the species. 


\section{$3 \quad$ Materials and Methods}

In short, the methodology to assess the effects of habitat loss on the ten seabird species consists of the following steps:

a. The selection and pre-processing of the data from the in ternational European Seabirds At Sea (ESAS, version 6.1) and Dutch MWTL (Monitoring Waterstaatkundige Toestand des Lands) databases for both the species that are under assessment for collision mortality (Table 2) as well as the species that are under assessment for habitat loss (Table 1).

b. The spatial conversion of the data from the previous step and the creation of dot maps and density maps for both the species that are under assessment for collision mortality (Table 2) as well as the species that are under assessment for habitat loss (Table 1).

c. The development of two new population models and update of the parameter values of five population models

d. The calculation of habitat loss casualties per species, bimonthly period, wind farm area and data subset (national/international)

e. The calculation of annual habitat loss mortality per species and scenario

f. The assessment of the population level effects of the additional mortalities due to habitat loss and testing against the Acceptable Levels of Impact (ALIs).

\subsection{Data preparation}

The selection and pre-processing of data was done in preparation of the creation of dot maps and density maps for both the species that are under assessment for collision mortality (Table 2) as well as for the species that are under assessment for habitat loss (Table 1).

\subsubsection{Data sources}

Two sources of data on seabird counts at sea were used; the European Seabirds At Sea (ESAS) database (version 6.1) that includes mostly ship-based counts of seabirds of the greater North Sea which was recently screened and updated by the Brussels 'Instituut voor Natuur- en Bosonderzoek' (INBO) and the 'Monitoring Waterstaatkundige Toestand des Lands' (MWTL) database that holds aerial surveys covering the Dutch section of the North Sea, provided by Bureau Waardenburg. More in-depth information on seabird counts can be found in previous studies (Camphuysen et al., 2004; Van Roomen et al., 2013; Fijn et al., 2020).

\subsubsection{Data selection}

Counts from 1991 onwards were selected with valid geographical position (latitude and longitude) and a non-zero sampled surface area, until the most recent data available (7-July-2020 for MWTL, 20December-2019 for ESAS). Each count was assigned a "period" (bimonthly periods, Table 4) based on the month of survey, which was later used to merge data (Baptist \& Wolf, 1993). An overview of the spatial effort per data source per bimonthly period can be found in Figure 1. Spatially, counts were selected that fall within the area of "Southern North Sea" \& "Central North Sea" (Figure 2). 
Table 4. Bimonthly periods used for the bird maps.

\begin{tabular}{ll} 
Period & Months \\
1 & August + September \\
\hline 2 & October + November \\
\hline 3 & December + January \\
\hline 4 & February + March \\
\hline 5 & April + May \\
\hline 6 & June + July \\
\hline
\end{tabular}

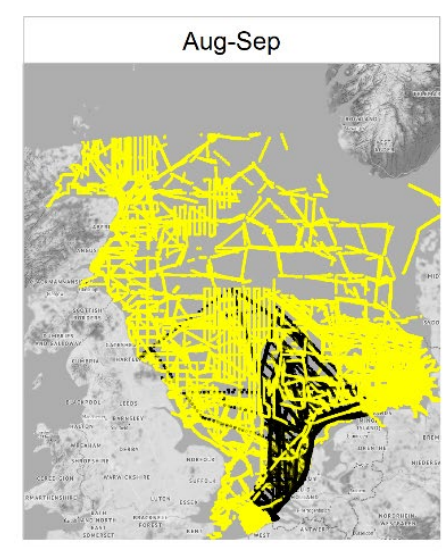

Feb-Mar

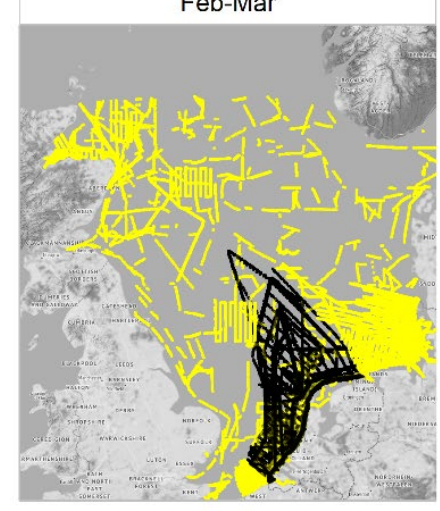

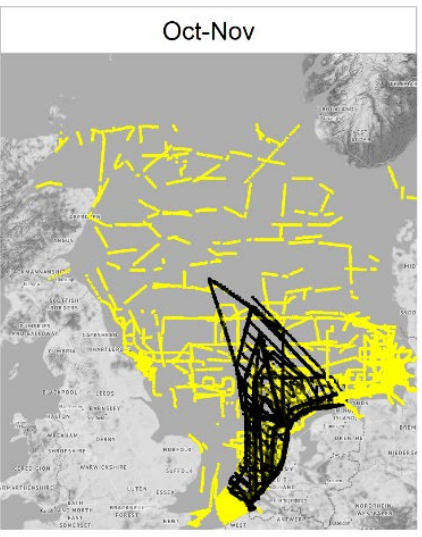

Apr-May

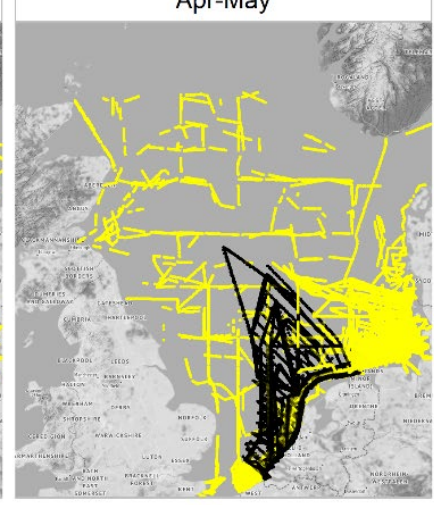

origin ESAS

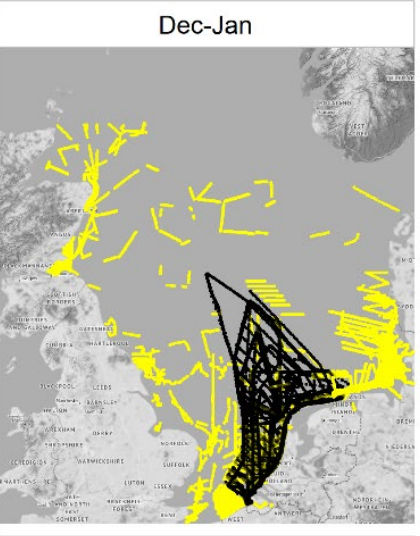

Jun-Jul

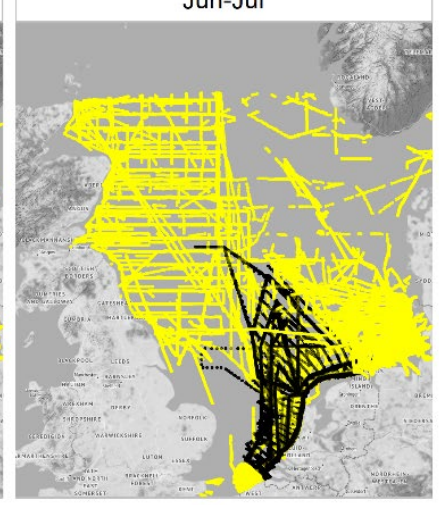

Figure 1. Counting effort of the two data sources used in this study (ESAS in yellow and MWTL in black) per bimonthly period. The background of this map is created with the ggmap package (Kahle \& Wickham, 2013).

In-line with the previous KEC-assessments, a number of (sub)species and observations were merged in the dataset because these were often not identified at species level (Table 5). For instance, redthroated divers and black-throated divers have been merged into "Diver sp.". Other observations were split into the species that are covered by the overarching term (Table 5). For example, the common guillemot/razorbill is the combined observation of common guillemots and razorbills. Counts were split based on the known bird community composition per bimonthly period and position. A grid of 50 by 50 $\mathrm{km}$ was used and all observations from 1991 onwards of relevant species were summed per grid cell per bimonthly period to calculate proportions of occurrence.

Counts were conducted in strips; a predetermined area with a certain length, width and hence, surface. Birds that were counted outside this strip, either flying or on the water, were not selected for further analysis. During ship-based counts (ESAS) the snapshot method was used for flying birds (Tasker et al., 1984). 
Table 5. Overview of overarching EUring codes and in which species counts are split or joined

\begin{tabular}{|c|c|c|c|}
\hline $\begin{array}{l}\text { EUring } \\
\text { code }\end{array}$ & Name & Split in: & Merged as: \\
\hline 6169 & Common tern/Arctic tern & & $\begin{array}{l}\text { Common tern, Arctic tern } \\
\text { ('commic tern') }\end{array}$ \\
\hline 59 & Diver sp. & & $\begin{array}{l}\text { Red-throated diver, black- } \\
\text { throated diver }\end{array}$ \\
\hline 5910 & $\begin{array}{l}\text { Larus fuscus, Larus } \\
\text { fuscus fuscus, Larus } \\
\text { fuscus graellsii }\end{array}$ & & Lesser black-backed gull \\
\hline 5920 & $\begin{array}{l}\text { Larus argentatus, Larus } \\
\text { argentatus argentatus }\end{array}$ & & European herring gull \\
\hline 6345 & $\begin{array}{l}\text { Common } \\
\text { guillemot/razorbill }\end{array}$ & Common guillemot, razorbill & \\
\hline 6549 & Alcidae & $\begin{array}{l}\text { Common guillemot, razorbill, } \\
\text { Atlantic puffin }\end{array}$ & \\
\hline 849 & Cormorant sp. & European shag, great cormorant & \\
\hline 5919 & $\begin{array}{l}\text { Lesser black-backed } \\
\text { gull/European herring } \\
\text { gull }\end{array}$ & $\begin{array}{l}\text { Lesser black-backed gull, } \\
\text { European herring gull }\end{array}$ & \\
\hline 6009 & Unidentified Larus gull & $\begin{array}{l}\text { Lesser black-backed gull, } \\
\text { European herring gull, yellow- } \\
\text { legged gull, Caspian gull, great } \\
\text { black-backed gull, black-headed } \\
\text { gull, common gull }\end{array}$ & \\
\hline 6049 & Unidentified gull & $\begin{array}{l}\text { Lesser black-backed gull, } \\
\text { European herring gull, yellow- } \\
\text { legged gull, Caspian gull, great } \\
\text { black-backed gull, black-headed } \\
\text { gull, common gull, Black-legged } \\
\text { kittiwake }\end{array}$ & \\
\hline 5709 & Unidentified skua & $\begin{array}{l}\text { Pomarine skua, Arctic skua, long- } \\
\text { tailed skua }\end{array}$ & \\
\hline
\end{tabular}

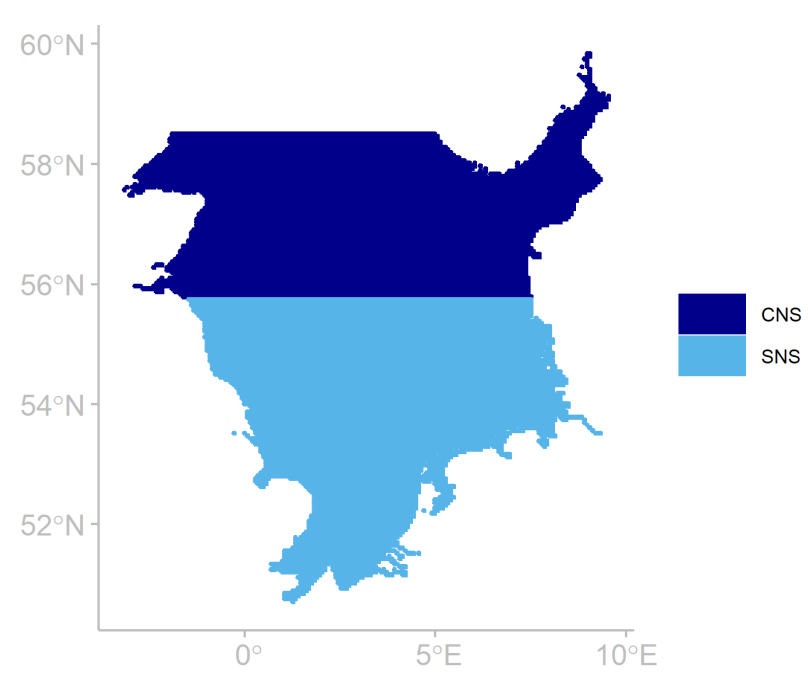

Figure 2. Counts were selected that fall within the area of "Central North Sea" (CNS) \& "Southern North Sea" (SNS) 


\subsubsection{Distance sampling}

Distance sampling is an established method for estimating animal densities (Buckland \& Turnock, 1992). This method assumes that the probability of detecting an animal decreases with distance. To correct for this distance effect, birds are assigned to counting bins. The first bin is the closest to the ship or airplane and the last is the furthest away. Every bin has an estimated standard width. Standard ship-based counts use a standard strip width of 300 meters perpendicular to the ship with four counting bins with widths of $50 \mathrm{~m} / 50 \mathrm{~m} / 100 \mathrm{~m} \mid 100 \mathrm{~m}$ (moving away from the ship). However, there are also counts with strip widths of 100, 150, 200 or 500 meters. All birds in the two closer bins of 50 meter were assumed to be detected, although, in reality there will always be some birds missed. Per species, the potentially missed individuals in the outer bins were estimated by comparing the summed numbers of birds in the first two bins with the numbers seen in the outer two bins. This allowed for a correction of birds missed in these outer bands, depending on the species. For each strip width, a separate correction factor was calculated. When relatively more birds were recorded in the outer two bins, resulting in a correction factor for missed birds that was below 1, the factor was changed to 1 and actual count values were used. For some large species, such as the common eider, which were presumably always detected in all bins, but for which insufficient numbers of observations were available, the correction factor was set at 1 . Ship counts with a transect width of 100 were left uncorrected, as they only include the two closer bins of 50 meter. The corrections were only calculated for birds counted on the water and not for flying birds: these usually moved over several bins and are presumably relatively easily detected.

Aerial surveys were conducted by MWTL and ESAS. MWTL surveys were conducted without distance estimation until mid-2014 and were left uncorrected in the used dataset. Later MWTL aerial counts were conducted with distance estimation. "Effective strip widths" were calculated by Bureau Waardenburg (Fijn et al., 2019; 2020) and were used to correct the area surveyed, instead of the number of observations. For the common eider, common scoter and Arctic skua, no factors were calculated and area surveyed was left uncorrected. Aerial counts conducted by ESAS either used two bins (44 m/91 m|163 m) or three bins (44 m/91 m/163 m/432 m), with the first $44 \mathrm{~m}$ left uncounted as this section was obscured from view (directly under the airplane). Number of birds (per meter strip width) in the first two bins were comparable, therefore only birds in the third bin (163 m-432 m) were corrected and counts with only two bins were left uncorrected. Correction factors were calculated in the same way as for the ship counts described above; expected numbers per species based on the first two bins were divided by the actual counted numbers per species. When the correction factor was below 1 , the factor was set at 1 and actual counts were used.

Number of birds were summed per position key (unique code per position per survey) per species and these sums were, where applicable, multiplied by the calculated correction factors. For ship-based counts, birds within the transect (scored as 'on the water' or 'flying') that were not assigned to a specific bin were added to the totals per position key, after correcting the numbers of birds that were assigned to specific bins. Totals per species per position key were converted to densities (numbers per square kilometer) by dividing the totals by the area surveyed (which is the transect width in kilometers multiplied by the kilometers travelled).

For all species, zeros were added to the dataset at every position where counts had been conducted but where that specific species was not seen.

\subsubsection{Count methods \& species counted}

The ESAS database is collated from surveys with different objectives. In most (standard) surveys, all species were counted. However, some surveys targeted specific species, or groups of species and these are not suitable to evaluate the presence of other species. Furthermore, in ship-based counts, flying birds are not always assigned to a transect ("no snapshot method for flying birds"). For these counting methods, we only included species that are mainly swimming. Within our selection these are the divers, common guillemot, razorbill, Atlantic puffin, common eider and common scoter. All observations of species that were not counted during a specific expedition (including the zeros) were not included in the dataset. 


\subsection{Density maps and dot maps}

Dot maps and density maps were calculated for both the species that are under assessment for collision mortality (Table 2) as well as the species that are under assessment for habitat loss (Table 1).

\subsubsection{Dot maps}

During the pre-processing of the raw data from both ESAS and MWTL, it was noted that for a number of species under evaluation for collision mortality, the available data were insufficient for full cover density maps. To determine which species are seen frequently enough to produce density maps, number of observations per species were plotted geographically. For species with few observations, the actual counts summed per observation key were mapped instead (Table 2).

\subsubsection{Density maps}

Seabird density maps were calculated following the methodology described in the previous assessments (KEC 2.0, Leopold et al., 2014; KEC 3.0, Van der Wal et al., 2018). While the previous assessment used data up to 2017 (Van der Wal et al., 2018), in the current assessment for both the international North Sea (INT) and the Dutch EEZ (NAT) maps (Figure 3), data up to 2020 were used (Table 6). Data from both ESAS and MWTL were used for international density maps, and, in contrast to the previous assessment, only MWTL data were used for the national maps (Table 6). Density maps were calculated both for species that are under assessment for the effect of habitat loss (Table 1) as well as for species that are under assessment for the effects of collision mortality (Table 2). For each bird species a total of fourteen density maps were calculated: a national and international map of each of the six bimonthly periods (Table 4 ) and of a yearly average.

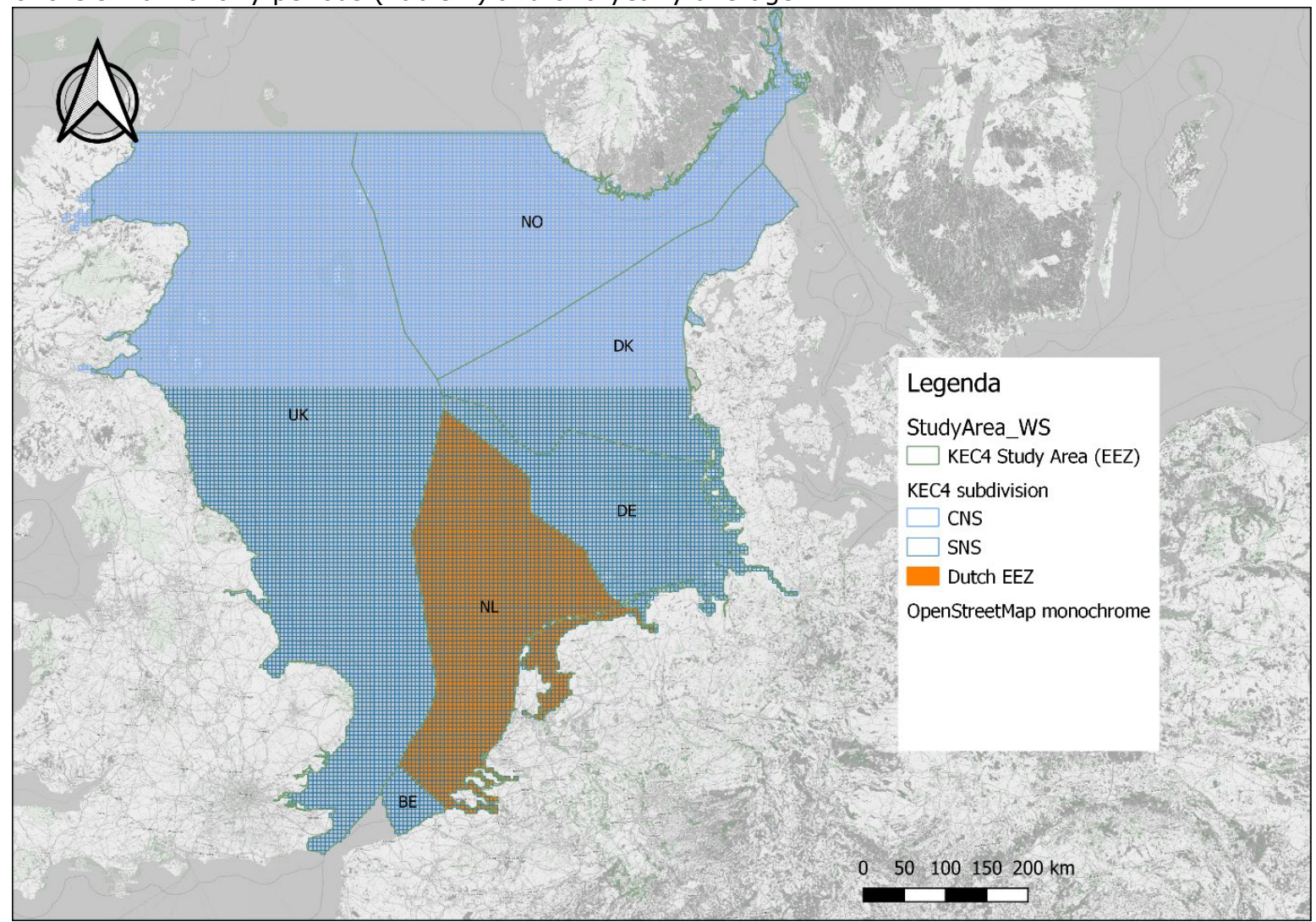

Figure 3. Study area with subdivisions, the Ducth EEZ (NAT, indicated in orange) and the international North Sea (INT, green outline).

The data were converted to grids with grid cell resolutions of $5 \times 5 \mathrm{~km}$. For some species, local densities tend to be too high due to clumping behaviour behind fishing vessels (Leopold et al., 2014). For these species, bird densities $>10$ birds $/ \mathrm{km}^{2}$ were spread at a medium ( $5 \times 5$ grid cells) or high $(11 \times 11 \mathrm{grid}$ 
cells) level before the grid interpolation. Whether such spreading of the data was performed is indicated per species in Table 1 and Table 2.

Values per grid cell were averaged per species and bimonthly period across databases. Interpolated gridded density maps were calculated based on inverse distance weighting (with nearest neighbour). A minimum of 5 cells and a maximum of 15 cells were included in the calculation of the value in each cell and cells at a maximum distance of $317 \mathrm{~km}$ could be included in the calculation. It was noted that for a few species data are scarce near the Scottish coast, as a result some empty areas were left in the Moray Firth and Firth of Forth. To fill those empty areas the nearest available data (to the East) were propagated westward. GIS processing, including inverse distance weighting, was executed with QGIS (version 3.16.6-Hannover) and Python (version 3.7.0).

Table 6. Data sources and periods used in calculating the seabird density maps for the international (International North Sea; INT) and national (Dutch EEZ; NAT) maps.

\begin{tabular}{lll} 
& International & National \\
Source(s) & ESAS + MWTL & MWTL \\
\hline Period (years) & $1991-2020$ & 2000-2020 \\
\hline
\end{tabular}

\subsection{Casualties per wind farm area}

Casualties due to habitat loss were calculated based on the same assumptions as for the previous assessments (KEC 2.0, Leopold et al., 2014; KEC 3.0, van der Wal et al., 2018). Figure 4 represents an overview of the offshore wind farms (OWF) that were included in the assessment (source: RWS). For the calculations of the casualties per national scenario and per Dutch OWF area in the national tables and figures, the national bird density maps were used. For the calculations of the casualties per international scenario, the international OWF areas and the Dutch OWF areas in the international figures, the international bird density maps were used.

The number of casualties $C$ per OWF area and per bimonthly period $i$ due to habitat loss were calculated as:

$$
C_{i}=B_{i} * \mathrm{RDRS} * E,
$$

which depends on the mean bird density in the OWF area $B_{i}$ per bimonthly period, the estimated area occupied by the OWF $E$ and the relative displacement risk score RDRS. 
The provided OWF boundaries delineate the outer edges where an offshore wind turbine can be positioned (Figure 4). For each area occupied/influenced by an OWF, the mean bird densities per bimonthly period $\left(B_{i}\right)$ were calculated based on the density values of the grid cells inside each OWF and inside a $500 \mathrm{~m}$ buffer around each OWF. All vector grid-cells that have some overlap with the buffered OWF were included in this mean. The estimated area occupied by the OWF (E) was calculated by multiplying the known area of the OWF by a scale factor. The scale factors are 1 for e.g. fully commissioned OWF and for most other OWF that are in a late state of development. The OWF in early development stages, labelled as concept/early planning resp. development zone, mostly have a scale factor well below 1 because the area under consideration is far larger than needed for the amount of power that is planned to be installed. The scale factors were calculated by estimating the required area assuming a future density of $10 \mathrm{MW} / \mathrm{km}^{2}$ (as per the direction given by RWS). The species specific relative displacement risk scores (RDRS) are listed in Table 7, the values were taken from Leopold et al. (2014; table 4.21).
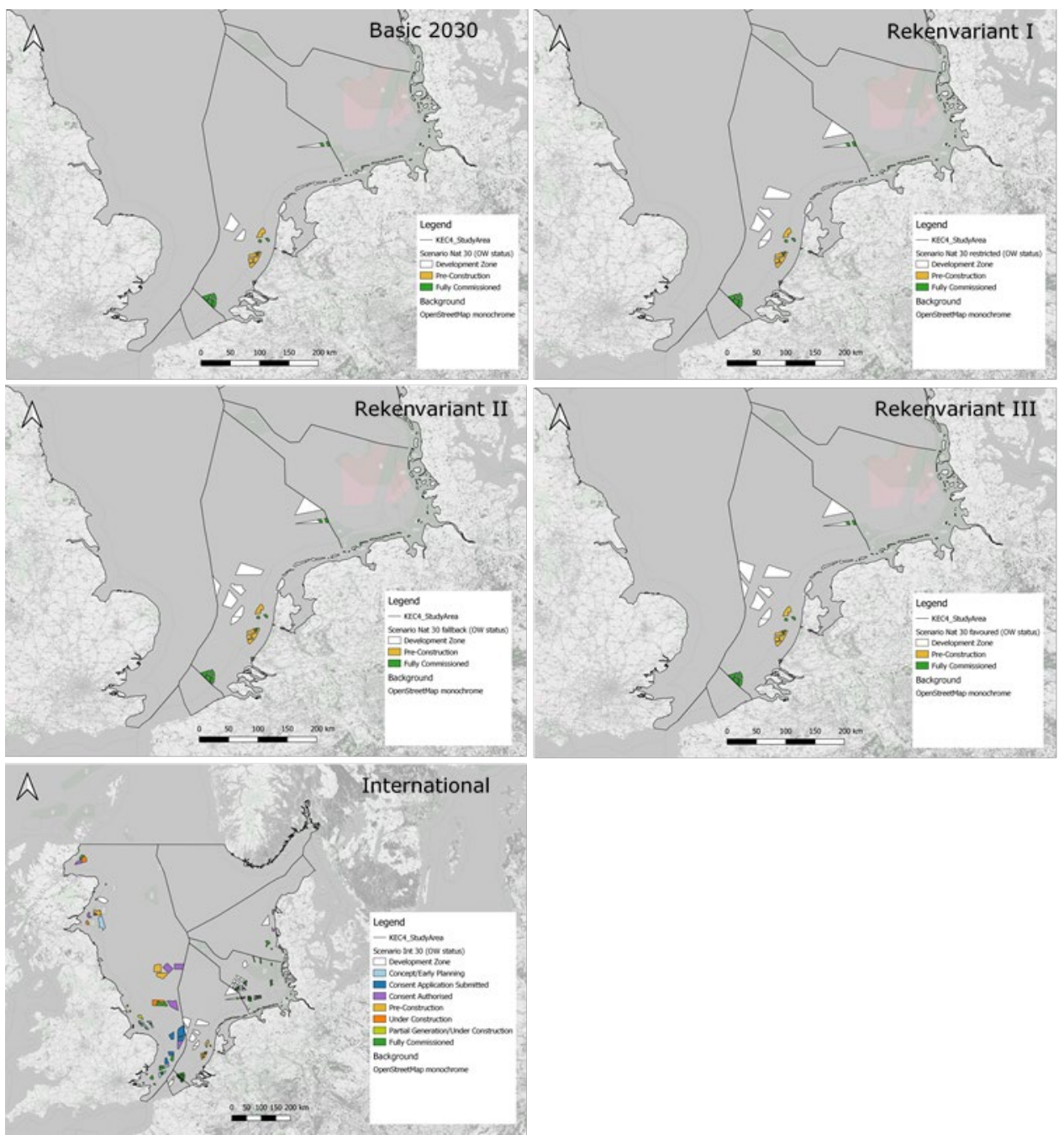

Figure 4. Overview of the OWFs included in the scenarios for the habitat loss calculations. 
Table 7. Relative Displacement Risk Score (RDRS) per seabird species. Values for RDRS were taken from Leopold et al. (2014; table 4.21).

\begin{tabular}{llll} 
EUring & Scientific Name & English name & RDRS \\
59 & Gavia sp. & Diver sp. & 0.080 \\
\hline 220 & Fulmarus glacialis & Northern fulmar & 0.004 \\
\hline 710 & Morus bassanus & Northern gannet & 0.008 \\
\hline 720 & Phalacrocorax carbo & Great cormorant & 0.012 \\
\hline 2060 & Somateria mollissima & Common eider & 0.048 \\
\hline 6130 & Melanitta nigra & Common scoter & 0.080 \\
\hline 6340 & Thalasseus sandvicensis & Sandwich tern & 0.024 \\
\hline 6360 & Uria aalge & Common guillemot & 0.036 \\
\hline 6540 & Fratercula arctica & Razorbill & 0.036 \\
\hline
\end{tabular}

\subsection{Mortality calculation}

Annual mortality probabilities due to habitat loss per scenario (Table 3 and Figure 4) were calculated from the estimated number of casualties per bimonthly period, for each of the species that is under assessment for habitat loss (Table 1). For the northern gannet and the sandwich tern also the collision mortality probabilities per scenario were considered in the population models. The collision mortality probabilities were taken from Potiek et al. (2021b). The effect of habitat loss and collision mortality were considered together in one population model because there is, for both species, only a single North Sea population that is assumed to suffer from both processes. The annual mortality probabilities were used in the population models to assess the population-level effects of the OWF secnarios.

We used the mean number of casualties over the six bimonthly periods to obtain a more robust estimate of the number of casualties. The mean number of casualties per period $\left(M_{\text {period }}\right)$ was divided by the maximum population abundance over all bimonthly periods $\left(N_{\max }\right)$. We assumed that the maximum abundance is most representative for the size of the population that suffers from habitat loss. The resulting mortality figure $m_{\text {period }}=M_{\text {period }} / N_{\max }$ was transposed to the annual mortality rate $m_{\text {annual }}$ as:

$$
m_{\text {annual }}=1-\left(1-m_{\text {period }}\right)^{6}
$$

The parameter $m_{\text {annual }}$ represents the annual mortality that results from habitat loss as a consequence of displacement from OWF areas. For the calculations of the mortality probabilities for the national scenarios, abundances based on the national bird density maps were used. For the calculations of the mortality probabilities for the international scenario, the international bird density maps were used.

\subsection{Matrix population models}

For the population-level assessment we used population models for seven of the ten species that are under assessment for habitat loss (Table 1). For the northern gannet and the sandwich tern, both the effects of habitat loss and collision mortality were assessed using a population model. The KEC 4.0 uses the same type of population models as used by Van Kooten et al. (2019). All model details and parameter derivations are described in Annex 1; the models are described in broad terms here.

The models for all species are stage-structured matrix population models that subdivide the population into different life stages. Consequently, the population is described by the population state vector that holds the number of individuals within each life stage. Individuals within a particular life stage have the same survival probability and reproductive output. A projection of the population into the future is made by multiplying the population state vector with a matrix that contains the stage-specific rates of 
survival and reproduction. This matrix is called the projection matrix. The projection matrix is a square matrix with the number of rows and columns equal to the number of life stages. The entry in the $i^{\text {th }}$ row and $j^{\text {th }}$ column of the projection matrix corresponds to the number of individuals of life stage $i$ that are derived from a single individual in life stage $j$ during one time step. The entries in the projection matrix are derived from species- and age-specific data on reproduction and survival. In KEC 4.0 we use deterministic, density-independent population models, which means that rates of survival and reproduction are independent of time and population abundance. Consequently, the entries of the projection matrix do not change from one time step to the next. Under such conditions, repeatedly multiplying the projection matrix with the population state vector results in an exponentially growing or declining population, with the long-term rate of population growth being solely determined by the projection matrix. This long-term population growth rate, or asymptotic population growth rate, is equal to the dominant eigenvalue of the projection matrix, and denoted by $\lambda$. The value of $\lambda$ indicates the relative change in population abundance; for $\lambda>1$ the population increases exponentially and for $\lambda<1$ the population declines exponentially. A population that grows or declines with a rate equal to $\lambda$ will have a stable stage distribution, i.e. the abundance of each life stage relative to the total population abundance remains constant. The stable stage distribution is equal to the right eigenvector associated with the dominant eigenvalue $\lambda$.

\subsubsection{General model structure}

In (sea)birds, age is an important determinant of survival and reproduction, therefore the categorization of life stages is primarily based on individual age. The number of life stages adopted for each species depends on the available information on age-specific survival and reproduction. A large number of stages can only be used if the available data are of sufficient resolution. Furthermore, it is only useful to consider different life stages if there are sufficiently large differences between those stages in terms of survival or reproduction. Here we describe the setup and analysis of the matrix models in general terms. Per species we discuss the adopted projection matrix and their parameter values.

We follow the matrix models previously described by Van Kooten et al. (2019) and consider separate summer and winter transition matrices. The summer transition matrix $\mathbf{A}_{\mathbf{s}}$ describes reproduction during the breeding season, i.e. the addition of new individuals to the first life stage. During the breeding season individuals do not die or age: there are no transitions between life stages. Therefore, survival of individuals equals 1 . The winter transition matrix $\mathbf{A}_{\mathbf{w}}$ describes survival and transition of individuals during the non-breeding season. If a life stage represents a single age-class, surviving individuals always transit to the next life stage. If a life stage comprises multiple age-classes, surviving individuals can remain in that life stage, although a fraction will transit to the next life stage. For a life stage $i$ that spans multiple ages, $P_{i}$ is the probability that an individual remains in stage $i$ and is derived by assuming a stable age distribution (Crouse et al., 1987):

$$
P_{i}=S_{a} \frac{\left(1-S_{a}^{n_{i}-1}\right)}{\left(1-S_{a}^{n_{i}}\right)},
$$

Here, $S_{a}$ is the annual survival probability and $n_{i}$ is the number of ages covered by life stage $i$. The probability that an individual survives and transits to stage $i+1$ is given by:

$$
G_{i}=\frac{S_{a}^{n_{i}}\left(1-S_{a}\right)}{\left(1-S_{a}^{n_{i}}\right)}
$$

If stage $i$ would comprise a single age class (i.e. $n_{i}=1$ ), $P_{i}$ correctly evaluates to zero and $G_{i}$ to $S_{a}$. The annual projection matrix $\mathbf{A}$ is calculated by a matrix multiplication of the winter and summer projection matrices: $\mathbf{A}=\mathbf{A}_{\mathbf{w}} \cdot \mathbf{A}_{\mathbf{s}}$. The order of the seasonal matrices in the matrix multiplication implies that the annual projection matrix projects the number of birds censused after winter and just before the breeding season begins. At this time, all individuals have just aged and new-born individuals of the previous summer have become 1 year old, but the new-borns of the current breeding season have not been censused yet. Turning the multiplication of the seasonal matrices around would result in a different annual projection matrix and a different stable stage structure, but with an identical population growth rate. It would just be looking at the population at a different moment in the year.

In reality, vital rates (reproduction and survival) vary between years, colonies and individuals and this leads to variation in the population growth rate $(\lambda)$. We allow for such variation by representing each model parameter by a statistical distribution described by a mean value and a standard deviation (SD). In case standard errors (SE) instead of standard deviations were reported, we calculated the 
standard deviation as $S D=S E \cdot \sqrt{n}$, with $n$ the number of samples. Similarly, the range rule, $S D=(\max$ - min) / 4, was used to estimated SD from minimum and maximum values. If 5\% and $95 \%$

confidence intervals were reported, we back-calculated the standard deviation as: $S D=\frac{C I_{95 \%}-C I_{5 \%}}{3.92} \sqrt{n}$.

We adopt the continuous beta distribution for all parameters that can only vary between zero and one. Parameters that can exceed one either follow a normal distribution or a truncated normal distribution. The distribution of the population growth rate is derived by calculating a large number of annual projection matrices. For each matrix, every parameter is sampled from its own distribution. Subsequently we calculate $\lambda$ for every projection matrix. Each parameter is sampled independently and we do not consider covariation between different parameters.

\subsubsection{Habitat loss mortality per life stage}

The habitat loss mortality was calculated per life stage for the seven species for which a population assessment was performed (Table 1). For the northern gannet and the sandwich tern also the life stage specific collision mortality was calculated. First, we assigned an 'OWF vulnerability' to each life stage. The OWF vulnerability $(0-1)$ represents the relative vulnerability of each life stage to OWFinduced mortality and can be used to exclude particular life stages from additional mortality, for example because species do not inhabit the North sea during certain parts of the life cycle. For the sandwich tern, we set the 'OWF vulnerability' to zero for the first two life stages $\left(J_{0}\right.$ and $\left.J_{12}\right)$ because these life stages are not present in the North Sea. This implies that only sandwich terns of $3+$ years old experience OWF-induced mortality. The two adult life stages of the sandwich tern have an OWF vulnerability of 1 . For the northern gannet, the stage-specific OWF vulnerabilities were based on the estimated age-distribution of the casualties of OWF collisions and were taken identical as used for the collision mortality assessment of the northern gannet (Potiek et al., 2021b). The vulnerability to OWFs is low (+/- 0.45) for the first two life stages of the northern gannet (age 0 and 1) and increases from age 2 onwards. For all other species, the 'OWF-vulnerability' was set to 1 for all life stages.

The OWF-induced mortality was applied to the survival parameters ( $S_{a}$, see equations (1) and (2)), and some life stages share the same survival parameter (see parameter derivations in Annex 1 ). The OWF vulnerabilities of the life stages that share a survival parameter were aggregated into an OWF vulnerability per survival parameter. This aggregation involved calculating the mean of the stagespecific OWF vulnerabilities, weighted by the stable distribution of each life stage. Parameter-specific OWF vulnerabilities were multiplied with the calculated OWF-induced additional mortality to arrive at additional mortality rates specific to each survival parameter.

Mortality rates were interpreted as finite probabilities that could vary between zero and one, as opposed to instantaneous rates. Accordingly, survival $\left(S_{a}\right)$ was calculated as the complement of mortality $m=1-S_{a}$. The OWF-affected survival rate, $S_{O W F}$, calculated from the OWF mortality, $m_{O W F}$, and the default survival rate $S$ following:

$$
S_{\text {OWF }}=1-\left((1-S)+m_{O W F}\right)
$$

\subsection{Population level effects and acceptable levels of impacts}

The acceptable levels of impact (ALIs) were defined for each of the species for which population-level effects of habitat loss were calculated (Table 8). For the species without population models (Table 1), no ALI thresholds could be defined. The concept of the ALIs has previously been described by Potiek et al. (2021a) and the values for the ALI thresholds were defined in a LNV working document. The values of $X$ and Pt that define the ALI thresholds (Table 8 ) were defined by LNV based on the IUCN status of the species (Potiek et al., 2021a). 
Table 8. Population-level effects of OWFs are tested against the Acceptable Level of Impact (ALI) thresholds (Potiek et al., 2021a) of which values were defined in a working document by LNV. X signifies how much smaller a population is allowed to be due to the influence of OWFs compared to a population without OWF. More exactly, it defines the population abundance that is deemed unacceptable after three bird generations, as a percentage of the population abundance expected without offshore wind farms. Pt signifies the probability that offshore wind farms are the cause of the violation of the $X$ value that is deemed unacceptable.

\begin{tabular}{|c|c|c|c|c|c|}
\hline EUring & $\begin{array}{l}\text { Scientific } \\
\text { name }\end{array}$ & English name & $\begin{array}{l}X \\
(\%)\end{array}$ & Pt & Population status \\
\hline 59 & Gavia $s p$ & Diver sp & 30 & 0.5 & $\begin{array}{l}\text { IUCN } 27 \text { least concern, NL non breeding } \\
\text { favourable (based on Gavia stellata) }\end{array}$ \\
\hline 220 & $\begin{array}{l}\text { Fulmarus } \\
\text { glacialis }\end{array}$ & Northern fulmar & 15 & 0.1 & IUCN 27 vulnerable, NL non breeding favourable \\
\hline 710 & Morus bassanus & Northern gannet & 30 & 0.5 & $\begin{array}{l}\text { IUCN } 27 \text { least concern, NL non breeding } \\
\text { favourable }\end{array}$ \\
\hline 6110 & $\begin{array}{l}\text { Thalasseus } \\
\text { sandvicensis }\end{array}$ & Sandwich tern & 30 & 0.5 & $\begin{array}{l}\text { IUCN } 27 \text { least concern, NL non breeding } \\
\text { unfavourable, NL breeding very unfavourable }\end{array}$ \\
\hline 6340 & Uria aalge & Common guillemot & 30 & 0.5 & $\begin{array}{l}\text { IUCN } 27 \text { least concern, European population } \\
\text { near threatened, NL non breeding favourable }\end{array}$ \\
\hline 6360 & Alca torda & Razorbill & 30 & 0.5 & $\begin{array}{l}\text { IUCN } 27 \text { least concern, European population } \\
\text { near threatened, NL nonbreeding unknown }\end{array}$ \\
\hline 6540 & $\begin{array}{l}\text { Fratercula } \\
\text { arctica }\end{array}$ & Atlantic puffin & 15 & 0.1 & $\begin{array}{l}\text { IUCN } 27 \text { near threatened, NL non breeding } \\
\text { unknown }\end{array}$ \\
\hline
\end{tabular}

For each species, we generated $1^{\mathrm{e} 5}$ stochastic annual projection matrices per scenario, including the 'null' scenario without additional OWF-induced mortality. The population growth rate $(\lambda)$ was calculated for each annual projection matrix as the real part of the dominant eigenvalue. Several summary statistics were calculated to characterize the resulting distribution of the population growth rates (mean, median, standard deviation and $5 \%$ and $95 \%$ quantiles). Population models were run using R software (R Core Team, 2020) and the 'KEC4popmodels' R-package (Hin, 2021), which was developed for the current project.

Following Potiek et al. (2021a), the ALI threshold that was used to test the effect of the OWFs in the population models was calculated for each species based on two factors:

1. The median population growth rate $\lambda_{X}$ that, over 3 generations, or 10 years, whichever period is longer (Potiek et al., 2021), resulted in a population abundance that is X\% lower than the population abundance with no OWFs (Table 8).

2. The probability that these lower population abundances are the result of the deployment of OWFs, $P_{\text {causality. }}$. The values of $P_{\text {causality }}$ were compared to the Pt values listed in Table 8 and when $P_{\text {causality }}$ was found to be large than Pt, the ALI threshold was exceeded.

To calculate $P_{\text {causality }}$ for each scenario, we determined the proportion of the distribution of population growth rates that is lower than $\lambda_{X}$. This proportion was termed $P_{\text {impact }}$. The $P_{\text {impact }}$ for the null scenario was the probability of a population growth rate lower than $\lambda_{X}$ without an OWF impact and was termed $P_{\text {falsepos }}$. For each scenario, we calculated the odds that a population growth rate lower than $\lambda_{X}$ did result from an OWF impact $\left(O_{\text {impact }}\right)$ as:

$$
O_{\text {impact }}=\frac{P_{\text {impact }}-P_{\text {falsepos }}}{P_{\text {impact }}} .
$$

From $O_{\text {impact }}$, the probability was calculated that the population growth rates lower than $\lambda_{X}$ resulted from the estimated OWF impact as:

$$
P_{\text {causality }}=\frac{O_{\text {impact }}}{1+O_{\text {impact }}}
$$




\section{$4 \quad$ Results}

\subsection{Population level effects}

The effects of habitat loss on the population level were not found to exceed the ALIs except for the northern gannet (Table 9, Morus bassanus). This exceedance is caused by the casualties due to collision mortality that lead to much higher mortality than habitat loss for this species (Table 13).

Table 9. Outcomes of population level assessment of the species under assessment for habitat loss. The effects of the tested scenarios do (TRUE) or do not (FALSE) exceed the species specific ALIs (see Table 8). The sandwich tern (Thalasseus sandvicensis) and the northern gannet (Morus bassanus) are under assessment for both effects of habitat loss and collision mortality and both were taken into consideration simultaneously for the test against the ALI.

$\mid$\begin{tabular}{l|l} 
Effects of both \\
habitat loss and \\
collision mortality
\end{tabular}

\begin{tabular}{|c|c|c|c|c|c|c|c|}
\hline Scenario & 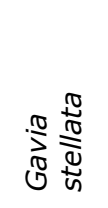 & $\begin{array}{l}\frac{n}{3} \cdot \frac{n}{\pi} \\
\frac{1}{\pi} \cdot \frac{\pi}{U} \\
\frac{1}{5} \frac{\pi}{a}\end{array}$ & $\begin{array}{l}0 \\
\frac{0}{0} \\
0 \\
0 \\
\frac{0}{5} \\
5\end{array}$ & $\begin{array}{l}\frac{\pi}{2} \\
\frac{\pi}{2} \\
\frac{1}{0} \\
\frac{1}{2}\end{array}$ & 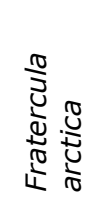 & 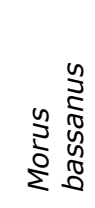 & 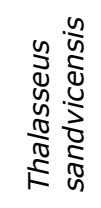 \\
\hline Basic 2030 & FALSE & FALSE & FALSE & FALSE & FALSE & TRUE & FALSE \\
\hline Rekenvariant III & FALSE & FALSE & FALSE & FALSE & FALSE & TRUE & FALSE \\
\hline Rekenvariant II & FALSE & FALSE & FALSE & FALSE & FALSE & TRUE & FALSE \\
\hline Rekenvariant I & FALSE & FALSE & FALSE & FALSE & FALSE & TRUE & FALSE \\
\hline International & FALSE & FALSE & FALSE & FALSE & FALSE & TRUE & FALSE \\
\hline
\end{tabular}




\subsection{Habitat loss casualties}

4.2.1 Casualties per OWF area
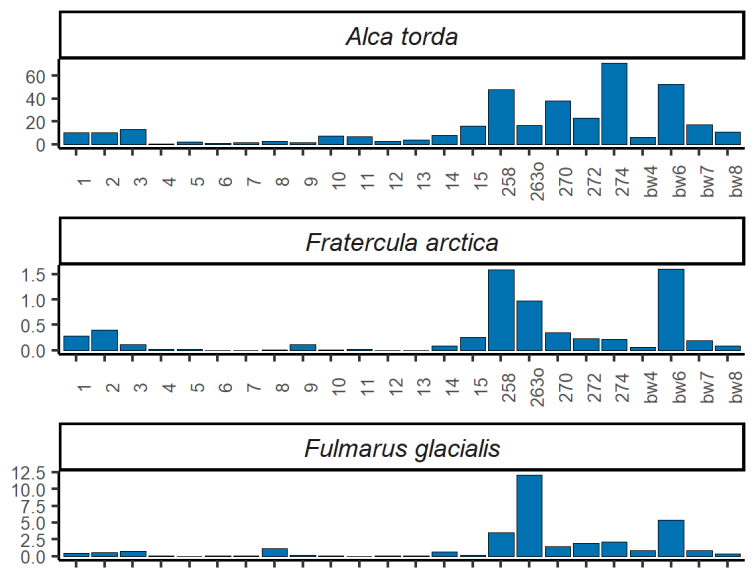

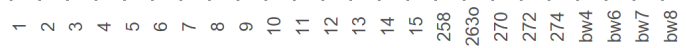

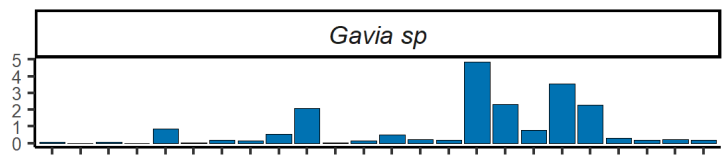

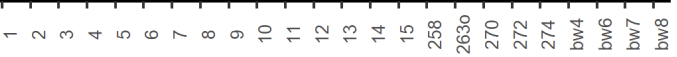
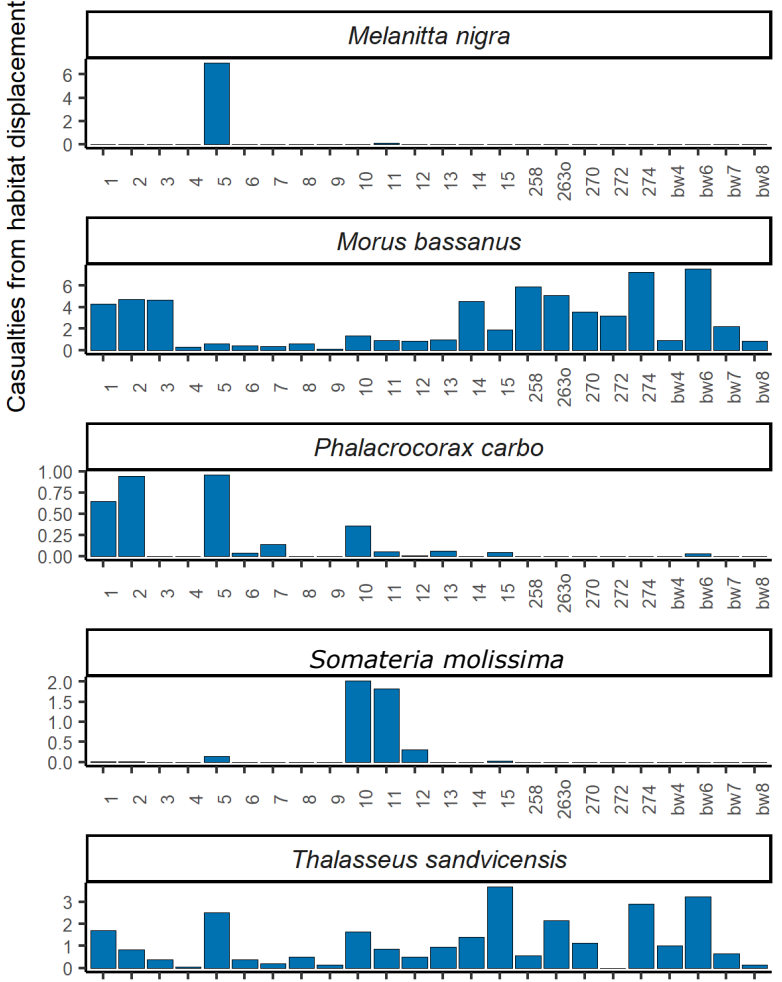

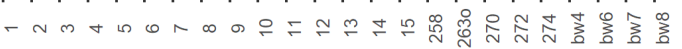

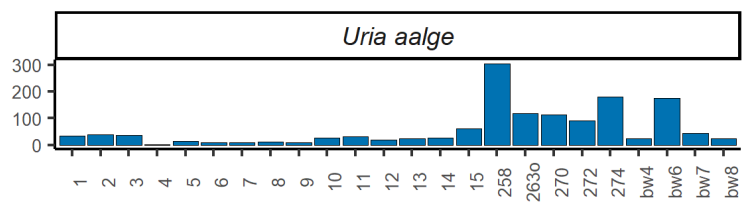

OWF ID

Figure 5. Estimated total number of casualties per year from habitat loss due to Dutch OWFs. Note the different scaling of the vertical axis between the different species. All OWFs are included in the national scenarios. Data represent the national subset (Table 10). Areas corresponding to the OWF IDs are shown in Figure 6 and their names can be found in Table 10. 


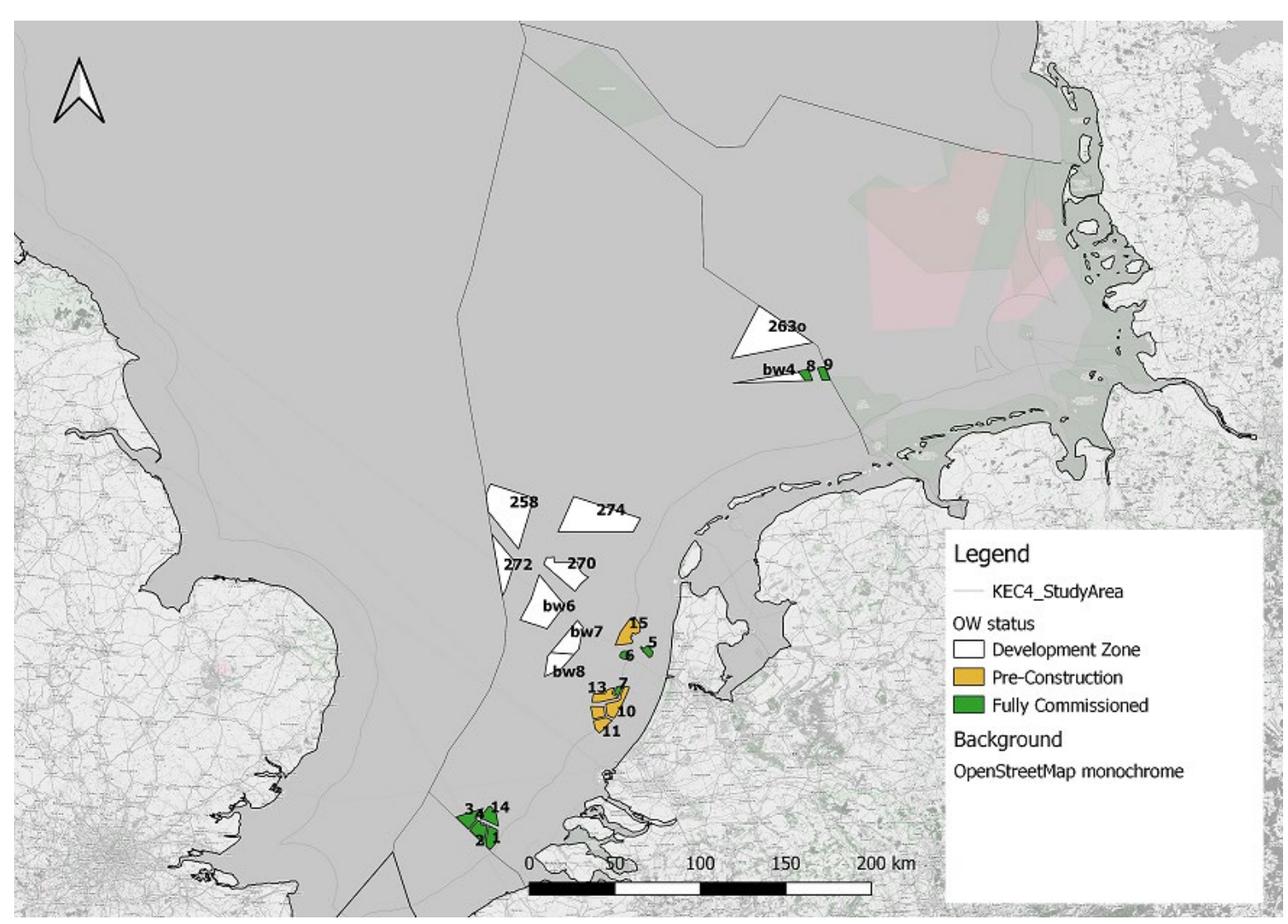

Figure 6. Dutch OWF areas with their OWF IDs

\subsubsection{National}

The estimated annual number of casualties from habitat displacement due to Dutch OWFs is shown per species for each wind farm in Figure $\mathbf{5}$ and Table 10. Appendix Table 38 lists the number of casualties per bimonthly period, species and OWF for all current Dutch OWFs and OWF search areas. There is considerable variation in the annual number of casualties between species and OWF areas. The estimated total number of casualties from habitat displacement across all Dutch OWF areas and species equals 1955 individuals per year for the national subset of the data (Table 10). $72.6 \%$ of the total number of casualties per year across the Dutch OWF areas are common guillemots (Figure 5 and Table 10). The second ranked species is the razorbill with $19.0 \%$. All the other species contribute less than $4 \%$ of the total estimated number of casualties per year.

Most casualties are predicted for OWF area ' Zoekgebied 1 Noord' (OWF id $=258$ ) with 368.9 casualties per annum (Table 10), followed by OWF areas 'Zoekgebied 2 Noord' (OWF id = 274) and 'IJmuiden Ver' (OWF id = bw6). Across all species, OWF area 'Zoekgebied 1 Noord' (OWF id = 258) alone is predicted to result in $18.9 \%$ of the total yearly number of casualties. Per GW, most casualties are predicted in different OWF areas (Table 11). 'Egmond aan Zee' (OWF id = 5), the 'Borssele' OWF areas (OWF ids $=1-4,14$ ) and 'Hollandse Kust Noord' (OWF id $=15$ ) are predicted to cause most casualties per GW. 
Table 10. Estimated total annual number of casualties for Dutch OWF areas per species and OWF area. Areas corresponding to the OWF IDs are shown in Figure 6.

\begin{tabular}{|c|c|c|c|c|c|c|c|c|c|c|c|}
\hline $\begin{array}{l}\text { OWF } \\
\text { id }\end{array}$ & OWF name & हो & 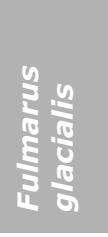 & 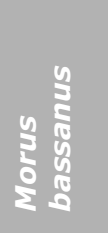 & 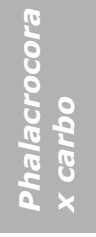 & 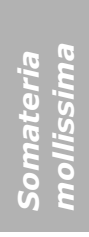 & $\frac{5}{8}$ & 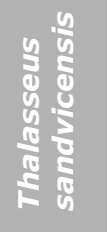 & 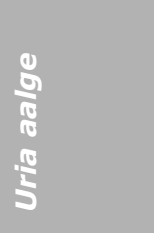 & $\begin{array}{l}\frac{8}{8} \\
\frac{8}{8} \\
\frac{8}{8}\end{array}$ & 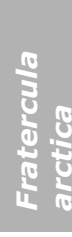 \\
\hline 1 & Borssele 2 & 0.1 & 0.5 & 4.3 & 0.6 & 0.0 & 0.0 & 1.7 & 33.9 & 10.3 & 0.3 \\
\hline 2 & Borssele 3 & 0.0 & 0.6 & 4.7 & 0.9 & 0.0 & 0.0 & 0.8 & 37.7 & 10.5 & 0.4 \\
\hline 3 & $\begin{array}{l}\text { Borssele } 4 \text { - } \\
\text { Blauwwind }\end{array}$ & 0.1 & 0.8 & 4.6 & 0.0 & 0.0 & 0.0 & 0.4 & 34.9 & 13.1 & 0.1 \\
\hline 4 & $\begin{array}{l}\text { Borssele Site V } \\
\text {-Two towers }\end{array}$ & 0.0 & 0.0 & 0.3 & 0.0 & 0.0 & 0.0 & 0.0 & 1.4 & 0.5 & 0.0 \\
\hline 5 & $\begin{array}{l}\text { Egmond aan } \\
\text { Zee }\end{array}$ & 0.8 & 0.0 & 0.6 & 1.0 & 0.1 & 7.0 & 2.5 & 13.1 & 2.1 & 0.0 \\
\hline 6 & $\begin{array}{l}\text { Prinses } \\
\text { Amaliawindpark }\end{array}$ & 0.0 & 0.1 & 0.4 & 0.0 & 0.0 & 0.0 & 0.4 & 7.7 & 1.1 & 0.0 \\
\hline 7 & $\begin{array}{l}\text { Eneco } \\
\text { Luchterduinen }\end{array}$ & 0.2 & 0.0 & 0.3 & 0.1 & 0.0 & 0.0 & 0.2 & 8.5 & 1.7 & 0.0 \\
\hline 8 & $\begin{array}{l}\text { Gemini Zee } \\
\text { energie }\end{array}$ & 0.2 & 1.1 & 0.6 & 0.0 & 0.0 & 0.0 & 0.5 & 10.9 & 2.8 & 0.0 \\
\hline 9 & $\begin{array}{l}\text { Gemini } \\
\text { Buitengaats }\end{array}$ & 0.5 & 0.2 & 0.1 & 0.0 & 0.0 & 0.0 & 0.1 & 9.2 & 1.5 & 0.1 \\
\hline 10 & $\begin{array}{l}\text { Hollandse Kust } \\
\text { Zuid Holland IV }\end{array}$ & 2.1 & 0.1 & 1.3 & 0.4 & 2.0 & 0.0 & 1.6 & 26.4 & 7.5 & 0.0 \\
\hline 11 & $\begin{array}{l}\text { Hollandse Kust } \\
\text { Zuid Holland III }\end{array}$ & 0.0 & 0.0 & 0.9 & 0.1 & 1.8 & 0.1 & 0.9 & 30.9 & 6.7 & 0.0 \\
\hline 12 & $\begin{array}{l}\text { Hollandse Kust } \\
\text { Zuid Holland II }\end{array}$ & 0.2 & 0.1 & 0.8 & 0.0 & 0.3 & 0.0 & 0.5 & 18.9 & 2.7 & 0.0 \\
\hline 13 & $\begin{array}{l}\text { Hollandse Kust } \\
\text { Zuid Holland I }\end{array}$ & 0.5 & 0.1 & 1.0 & 0.1 & 0.0 & 0.0 & 0.9 & 24.3 & 3.7 & 0.0 \\
\hline 14 & Borssele 1 & 0.2 & 0.7 & 4.5 & 0.0 & 0.0 & 0.0 & 1.4 & 26.0 & 8.2 & 0.1 \\
\hline 15 & $\begin{array}{l}\text { Hollandse Kust } \\
\text { Noord }\end{array}$ & 0.2 & 0.2 & 1.9 & 0.0 & 0.0 & 0.0 & 3.7 & 60.2 & 16.0 & 0.3 \\
\hline 258 & $\begin{array}{l}\text { Zoekgebied } 1 \\
\text { Noord }\end{array}$ & 4.9 & 3.5 & 5.9 & 0.0 & 0.0 & 0.0 & 0.6 & 304.6 & 47.8 & 1.6 \\
\hline 2630 & $\begin{array}{l}\text { Zoekgebied } 5 \\
\text { Oost origineel }\end{array}$ & 2.3 & 12.1 & 5.1 & 0.0 & 0.0 & 0.0 & 2.1 & 118.3 & 16.4 & 1.0 \\
\hline 270 & $\begin{array}{l}\text { IJmuiden Ver } \\
\text { Noord }\end{array}$ & 0.8 & 1.4 & 3.5 & 0.0 & 0.0 & 0.0 & 1.1 & 112.2 & 37.9 & 0.3 \\
\hline 272 & $\begin{array}{l}\text { Zoekgebied } 1 \\
\text { Zuid }\end{array}$ & 3.6 & 2.0 & 3.2 & 0.0 & 0.0 & 0.0 & 0.0 & 91.3 & 22.9 & 0.2 \\
\hline 274 & $\begin{array}{l}\text { Zoekgebied } 2 \\
\text { Noord }\end{array}$ & 2.3 & 2.1 & 7.2 & 0.0 & 0.0 & 0.0 & 2.9 & 181.2 & 71.2 & 0.2 \\
\hline bw4 & $\begin{array}{l}\text { Ten noorden } \\
\text { van de } \\
\text { Waddeneilanden }\end{array}$ & 0.3 & 0.8 & 0.9 & 0.0 & 0.0 & 0.0 & 1.0 & 24.3 & 6.2 & 0.1 \\
\hline bw6 & IJmuiden Ver & 0.2 & 5.4 & 7.6 & 0.0 & 0.0 & 0.0 & 3.2 & 175.5 & 52.8 & 1.6 \\
\hline bw7 & $\begin{array}{l}\text { Hollandse Kust } \\
\text { West }\end{array}$ & 0.2 & 0.9 & 2.2 & 0.0 & 0.0 & 0.0 & 0.6 & 44.6 & 17.5 & 0.2 \\
\hline bw8 & $\begin{array}{l}\text { Hollandse Kust } \\
\text { West zuidelijke } \\
\text { punt }\end{array}$ & 0.2 & 0.4 & 0.9 & 0.0 & 0.0 & 0.0 & 0.1 & 22.5 & 10.7 & 0.1 \\
\hline Total & & 19.8 & 33.1 & 62.9 & 3.3 & 4.3 & 7.1 & 27.5 & 1418.6 & 371.9 & 6.6 \\
\hline
\end{tabular}


Table 11. Estimated total annual number of casualties for Dutch OWF areas for all species and OWF areas per GW. Areas corresponding to the OWF IDs are shown in Figure 6.

\begin{tabular}{|c|c|c|c|c|c|c|c|c|c|c|c|}
\hline $\begin{array}{l}\mathrm{J} \\
\mathrm{I} \\
\mathrm{u}\end{array}$ & OWF name & $\begin{array}{l}\text { जे } \\
\text { है } \\
\text { है }\end{array}$ & 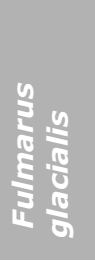 & 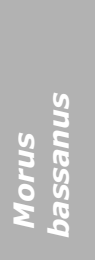 & 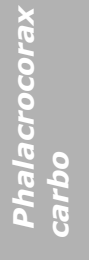 & 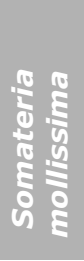 & $\frac{\sqrt{2}}{\frac{2}{2}}$ & 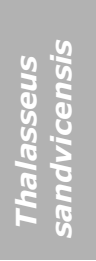 & $\frac{2}{8}$ & $\frac{\sqrt{4}}{8}$ & 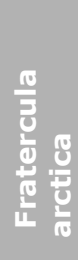 \\
\hline 1 & Borssele 2 & 0.2 & 1.3 & 11.5 & 1.7 & 0.0 & 0.0 & 4.6 & 90.1 & 27.5 & 0.8 \\
\hline 2 & Borssele 3 & 0.0 & 1.5 & 12.9 & 2.6 & 0.0 & 0.0 & 2.3 & 102.9 & 28.7 & 1.1 \\
\hline 3 & Borssele 4 - Blauwwind & 0.2 & 2.1 & 12.7 & 0.0 & 0.0 & 0.0 & 1.0 & 95.4 & 35.8 & 0.3 \\
\hline 4 & $\begin{array}{l}\text { Borssele Site V - } \\
\text { Two towers }\end{array}$ & 0.0 & 2.1 & 15.2 & 0.0 & 0.0 & 0.0 & 2.1 & 71.2 & 26.2 & 1.1 \\
\hline 5 & Egmond aan Zee & 7.8 & 0.2 & 5.7 & 8.9 & 1.3 & 64.8 & 23.4 & 121.3 & 19.4 & 0.3 \\
\hline 6 & $\begin{array}{l}\text { Prinses } \\
\text { Amaliawindpark }\end{array}$ & 0.2 & 0.5 & 3.2 & 0.3 & 0.0 & 0.0 & 3.3 & 64.5 & 9.2 & 0.0 \\
\hline 7 & Eneco Luchterduinen & 1.4 & 0.2 & 2.5 & 1.1 & 0.0 & 0.0 & 1.6 & 66.2 & 13.4 & 0.0 \\
\hline 8 & Gemini Zee energie & 0.5 & 3.7 & 2.0 & 0.0 & 0.0 & 0.0 & 1.7 & 36.4 & 9.3 & 0.0 \\
\hline 9 & Gemini Buitengaats & 1.8 & 0.7 & 0.4 & 0.0 & 0.0 & 0.0 & 0.4 & 30.7 & 5.0 & 0.4 \\
\hline 10 & $\begin{array}{l}\text { Hollandse Kust Zuid } \\
\text { Holland IV }\end{array}$ & 5.5 & 0.3 & 3.4 & 0.9 & 5.3 & 0.0 & 4.3 & 68.6 & 19.5 & 0.0 \\
\hline 11 & $\begin{array}{l}\text { Hollandse Kust Zuid } \\
\text { Holland III }\end{array}$ & 0.0 & 0.1 & 2.3 & 0.1 & 4.7 & 0.2 & 2.2 & 80.2 & 17.4 & 0.1 \\
\hline 12 & $\begin{array}{l}\text { Hollandse Kust Zuid } \\
\text { Holland II }\end{array}$ & 0.4 & 0.1 & 2.2 & 0.0 & 0.8 & 0.0 & 1.3 & 49.1 & 7.0 & 0.0 \\
\hline 13 & $\begin{array}{l}\text { Hollandse Kust Zuid } \\
\text { Holland I }\end{array}$ & 1.3 & 0.3 & 2.6 & 0.2 & 0.0 & 0.0 & 2.4 & 63.2 & 9.5 & 0.0 \\
\hline 14 & Borssele 1 & 0.6 & 1.8 & 12.1 & 0.0 & 0.0 & 0.0 & 3.7 & 69.1 & 21.8 & 0.2 \\
\hline 15 & $\begin{array}{l}\text { Hollandse Kust Noord } \\
\text { (Tender 2019) }\end{array}$ & 0.2 & 0.3 & 2.7 & 0.1 & 0.0 & 0.0 & 5.3 & 86.0 & 22.8 & 0.4 \\
\hline 258 & Zoekgebied 1 Noord & 1.2 & 0.9 & 1.5 & 0.0 & 0.0 & 0.0 & 0.1 & 76.2 & 12.0 & 0.4 \\
\hline 270 & IJmuiden Ver Noord & 0.4 & 0.7 & 1.8 & 0.0 & 0.0 & 0.0 & 0.6 & 56.1 & 18.9 & 0.2 \\
\hline 272 & Zoekgebied 1 Zuid & 1.8 & 1.0 & 1.6 & 0.0 & 0.0 & 0.0 & 0.0 & 45.7 & 11.5 & 0.1 \\
\hline 274 & Zoekgebied 2 Noord & 0.6 & 0.5 & 1.8 & 0.0 & 0.0 & 0.0 & 0.7 & 45.3 & 17.8 & 0.1 \\
\hline 2630 & $\begin{array}{l}\text { Zoekgebied } 5 \text { Oost } \\
\text { origineel }\end{array}$ & 0.6 & 3.0 & 1.3 & 0.0 & 0.0 & 0.0 & 0.5 & 29.6 & 4.1 & 0.2 \\
\hline bw4 & $\begin{array}{l}\text { Ten noorden van de } \\
\text { Waddeneilanden - } \\
\text { (Tender 2022) }\end{array}$ & 0.4 & 1.2 & 1.3 & 0.0 & 0.0 & 0.0 & 1.4 & 34.8 & 8.9 & 0.1 \\
\hline bw6 & IJmuiden Ver & 0.0 & 1.4 & 1.9 & 0.0 & 0.0 & 0.0 & 0.8 & 43.9 & 13.2 & 0.4 \\
\hline bw7 & $\begin{array}{l}\text { Hollandse Kust West - } \\
\text { (Tender 2020/2021) }\end{array}$ & 0.2 & 0.6 & 1.6 & 0.0 & 0.0 & 0.0 & 0.5 & 31.9 & 12.5 & 0.1 \\
\hline bw8 & $\begin{array}{l}\text { Hollandse Kust West } \\
\text { zuidelijke punt }\end{array}$ & 0.2 & 0.6 & 1.2 & 0.0 & 0.0 & 0.0 & 0.2 & 32.2 & 15.3 & 0.1 \\
\hline
\end{tabular}




\subsubsection{International}

Casualties per bimonthly period, species and international OWF area are presented in a separate document (Electronic supplement E1,

E1_Table_KEC4.0_Casualties_IntOWPs_BatchINT_ScenarioOWPs.pdf). The yearly number of casualties per species for all OWF areas are shown in Electronic supplement E2

(E2_Casualties_OWP_Species_INT.pdf), an overview of the casualties per international EEZ in Error! Reference source not found. and per OWF area in Figure 8.

The species with the highest number of estimated victims is the common guillemot in nearly all countries, with the exception of Denmark (Error! Reference source not found.). On the Danish EEZ the diver sp. are the hardest hit species (group). This species (group) is also clearly visible within the German pie diagram. For the Dutch, Belgian and UK EEZ, the species with second most casualties is the razorbill. Also per OWF, the casualties mostly consist of common guillemots for international OWFs (Figure 8). Yet, in the German and Danish OWFs, divers are often the species with most casualties and the same occurs in some northern UK OWFs (Figure 8). In some German and Danish OWFs, the common scoter is the most common casualty. In a few UK OWFs, this is the razorbill (Figure 8 ).

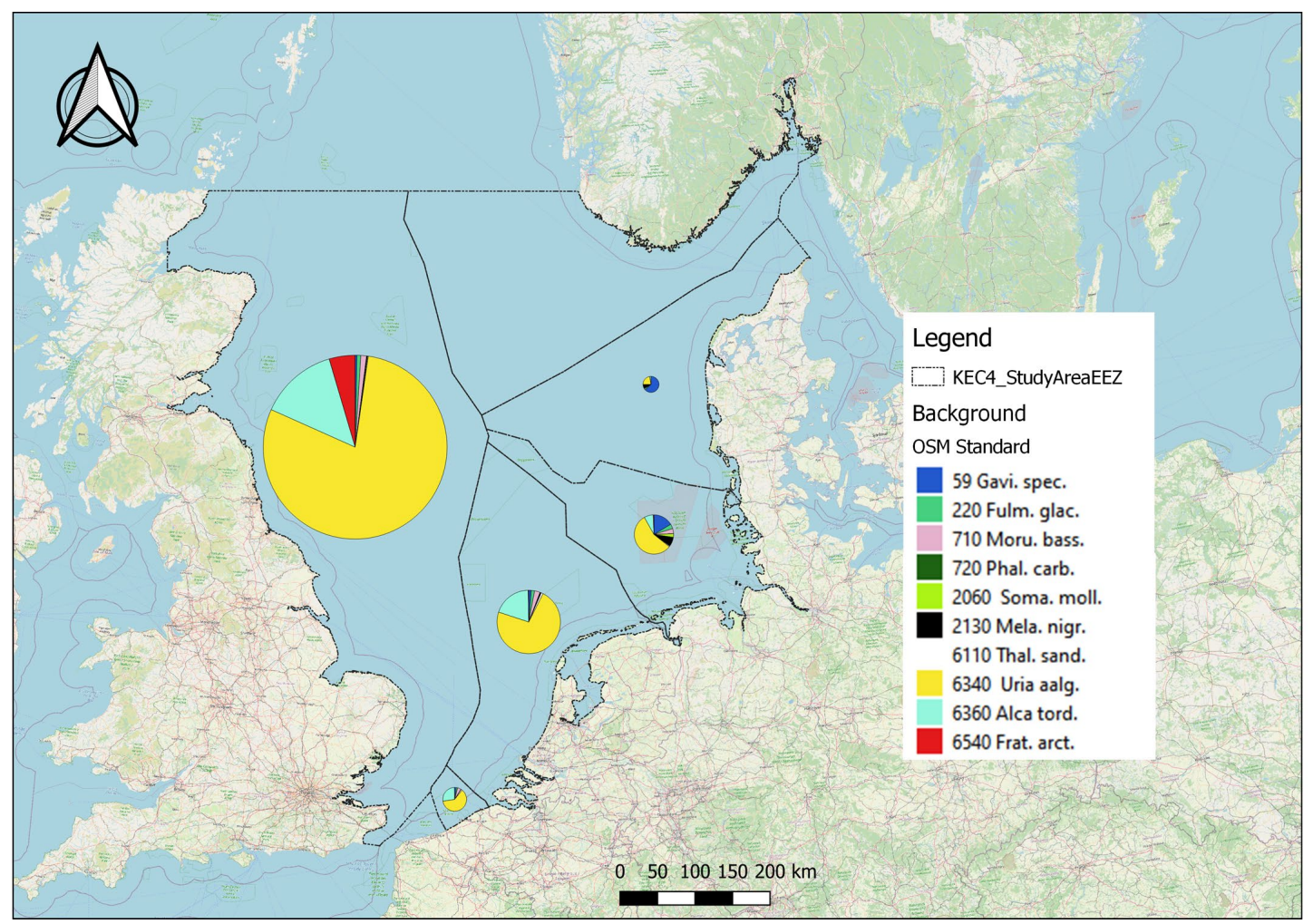

Figure 7. Habitat loss casualties by EEZ. Pie diagram size indicates total number, with segment size representing the proportion per species. The legend indicates the colour per species (EUring and scientific name). 


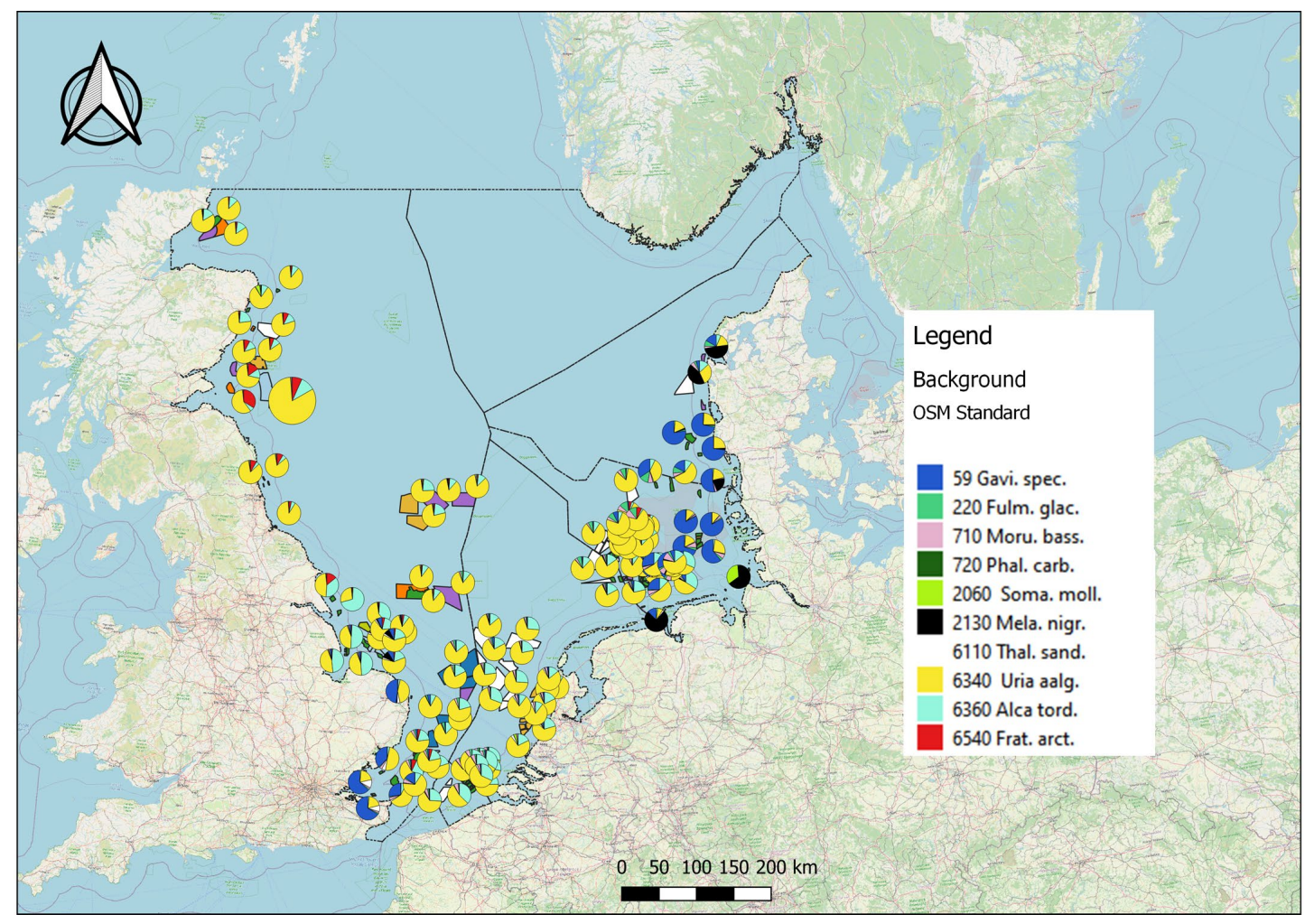

Figure 8. Overview of habitat loss casualties for the international scenario. Size of pie diagrams indicates total number of casualties, segments indicate the proportion per species. The legend indicates the colour per species (EUring and scientific name). 


\subsubsection{Casualties and mortality estimates per scenario}

The total number of casualties of habitat loss per year per OWF scenario are shown in Table 12 for all ten species being evaluated for habitat loss. The total number of casualties across species are lower for the Rekenvariant I and Rekenvariant II scenarios than for Rekenvariant III.

Table 12. Estimated yearly total number of casualties per scenario and species.

\begin{tabular}{|c|c|c|c|c|c|c|c|c|c|c|c|}
\hline Scenario & $\begin{array}{l}\text { के } \\
\text { है } \\
\text { c }\end{array}$ & 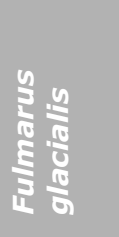 & 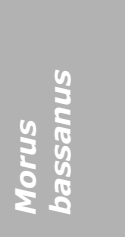 & 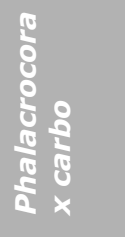 & 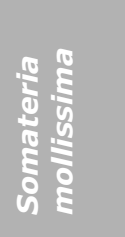 & $\frac{\sqrt{2}}{\frac{10}{2}}$ & 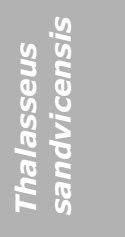 & 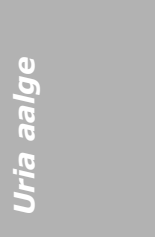 & $\begin{array}{l}\frac{8}{8} \\
\frac{8}{8} \\
8\end{array}$ & 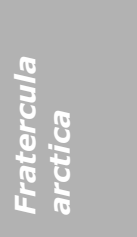 & తి \\
\hline Basic 2030 & 5.8 & 11.6 & 37.1 & 3.3 & 4.3 & 7.1 & 20.6 & 588.4 & 165.0 & 3.2 & 846.3 \\
\hline Rekenvariant II & 14.9 & 29.6 & 57.0 & 3.3 & 4.3 & 7.1 & 26.9 & 1114.0 & 324.1 & 5.0 & 1586.2 \\
\hline Rekenvariant III & 19.8 & 33.1 & 62.9 & 3.3 & 4.3 & 7.1 & 27.5 & 1418.6 & 371.9 & 6.6 & 1955.1 \\
\hline Rekenvariant I & 11.4 & 27.6 & 53.9 & 3.3 & 4.3 & 7.1 & 26.9 & 1022.6 & 301.1 & 4.8 & 1463.1 \\
\hline International & 266.9 & 171.2 & 250.7 & 3.5 & 34.3 & 87.2 & 46.2 & 14148.1 & 2609.6 & 707.8 & 18325.5 \\
\hline
\end{tabular}

Based on the mean numbers of estimated casualties and the maximum population abundances, the proportion mortality due to habitat loss and collision mortality on the population level was calculated for the species that are assessed at the population level (Table 13). Note that for the northern gannet and the sandwich tern, the habitat loss, collision mortality and total mortality are reported. The mortality probabilities are eventually used in the population models.

Because the mortality probabilities are relative to the population size, they give an indication of how strong each population will be affected by the casualties. While the diver spec. were estimated to have less casualties than the northern fulmar, the mortality probability for the diver spec. are estimated to be higher than for the northern fulmar (Table 13). Error! Reference source not found. The estimated values for the habitat loss mortality are highest for the common guillemot and razorbill. Yet, for the northern gannet, the highest OWF mortality probabilities were estimated, due to the addition of the collision mortalities (Table 13).

Table 13. Estimated annual mortality probability per species and scenario. For the northern gannet (Morus bassanus) and the sandwich tern (Thalasseus sandvicensis) mortality due to habitat loss (hab.) and collision mortality (coll.) as well as total (tot.) mortality are reported separately.

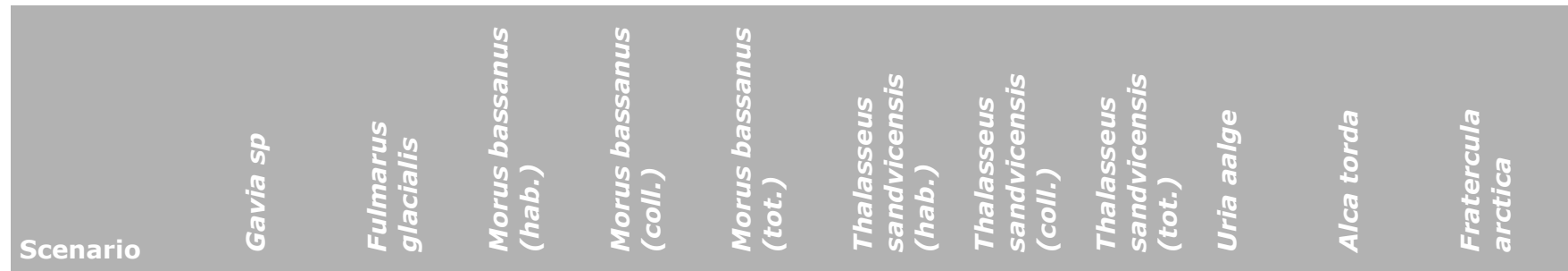

\begin{tabular}{|c|c|c|c|c|c|c|c|c|c|c|c|}
\hline Basic 2030 & 0.00102 & 0.00023 & 0.00116 & 0.03657 & 0.03770 & 0.00091 & 0.00142 & 0.00233 & 0.00258 & 0.00267 & 0.00144 \\
\hline Rekenvariant II & 0.00263 & 0.00059 & 0.00179 & 0.05432 & 0.05603 & 0.00119 & 0.00176 & 0.00294 & 0.00488 & 0.00524 & 0.00228 \\
\hline Rekenvariant III & 0.00348 & 0.00066 & 0.00197 & 0.05893 & 0.06080 & 0.00122 & 0.00183 & 0.00304 & 0.00622 & 0.00602 & 0.00299 \\
\hline Rekenvariant I & 0.00200 & 0.00055 & 0.00169 & 0.05189 & 0.05351 & 0.00119 & 0.00176 & 0.00294 & 0.00448 & 0.00487 & 0.00217 \\
\hline International & 0.00826 & 0.00046 & 0.00154 & 0.04223 & 0.04371 & 0.00178 & 0.00249 & 0.00427 & 0.00841 & 0.01142 & 0.00305 \\
\hline
\end{tabular}




\subsection{Diver sp. (Gavia sp.)}

\subsubsection{Diver sp. habitat loss casualties and mortality}

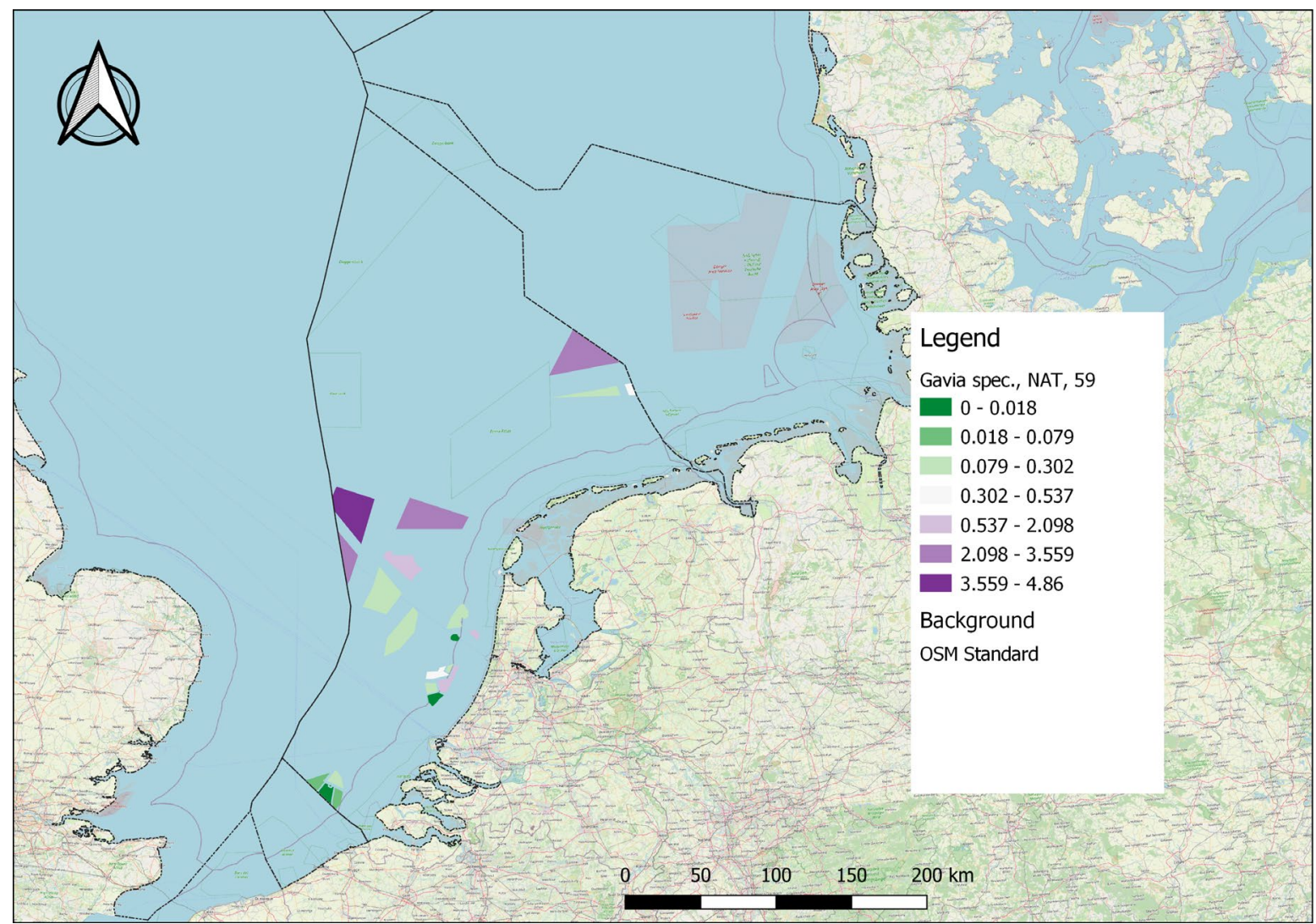

Figure 9. Diver sp. (gavia sp., EUring 59; note that red-throated diver and black-throated diver are considered together Table 5) total annual habitat loss casualties per OWF included in the national scenarios.

The national map (Figure 9) of the numbers of habitat loss diver sp. casualties shows that relatively more casualties are to be expected in the areas that are situated more to the north and further away from the coast. The international map (Figure 10) shows a similar picture for the Dutch EEZ, with relatively fewer casualties closer to the coast and more to the south. Internationally, most casualties are predicted to occur along the German and Danish coasts and in the central and northern part of the UK EEZ. Bird density maps of each bimonthly period and of the annual averages can be found in separate documents (Electronic appendices E3 and E4; respectively E3_DensityMaps_19species_NATINT_period.pdf and E4_DensityMaps_19species_NATINT_yearly.pdf). 


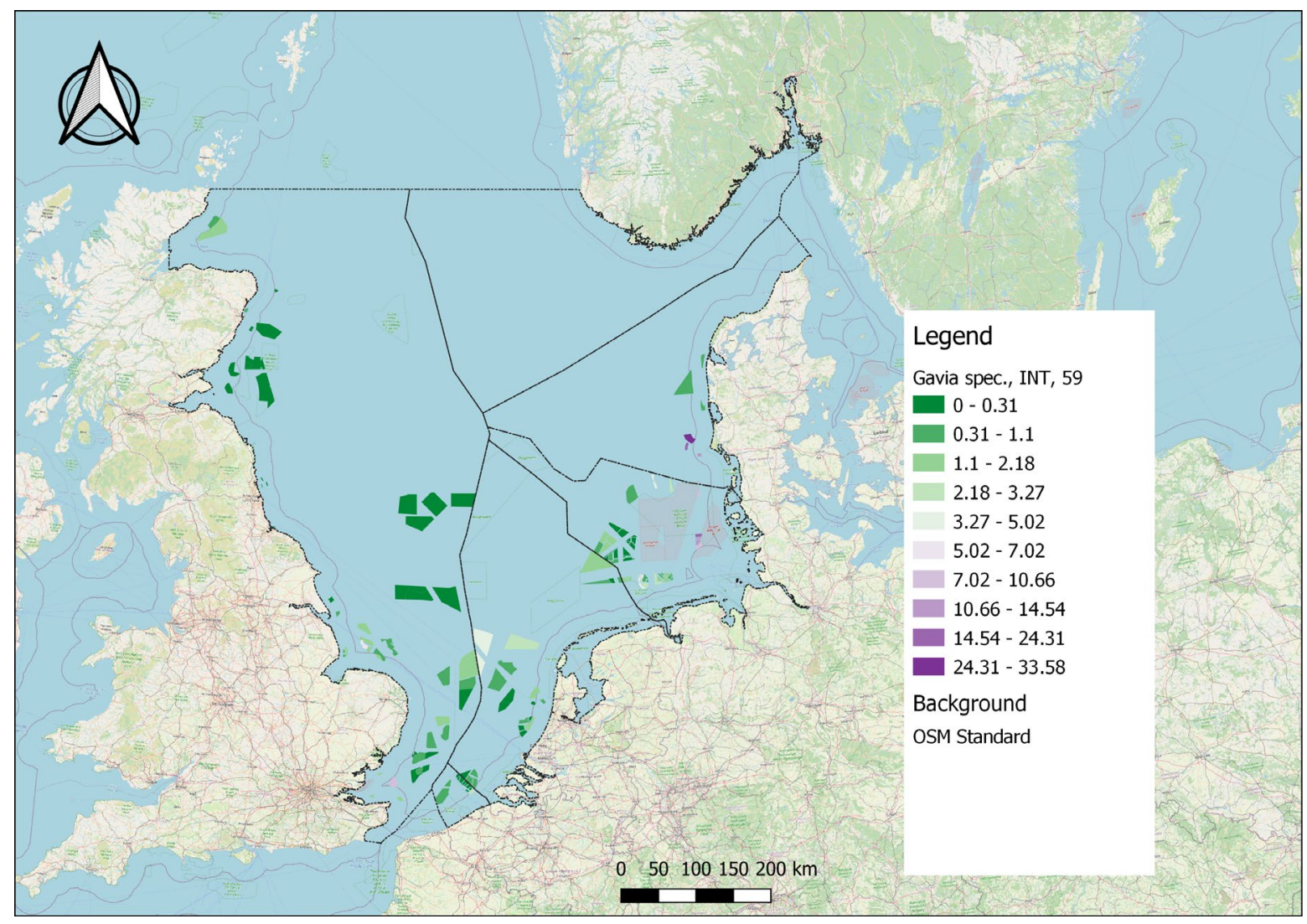

Figure 10. Diver spec. (Gavia sp., EUring 59; note that red-throated diver and black-throated diver are considered together Table 5) total annual habitat loss casualties per OWF included the international scenario.

The estimated number of diver sp. casualties per bimonthly period varies between 1 and 4 for the national scenarios and is highest for the 'Rekenvariant III' scenario (Table 14). Using a maximum estimated abundance of 5680 individuals this corresponds to an additional annual mortality of 0.1 to $0.2 \%$ (Table 14). Both mean number of bimonthly casualties and maximum abundance are higher in the 'International' scenario. The estimated additional annual mortality for the international scenario equals $0.8 \%$ (Table 14). This leads to an estimated decrease of juvenile and adult survival of 1.35 and $0.96 \%$. The number of casualties per bimonthly period for Gavia sp. are shown for each Dutch OWF area in Annex Table 38.

Table 14. Overall, immature (J) and adult (A) mortality (mort) and survival values for diver sp. (Gavia sp., EUring 59; note that red-throated diver and black-throated diver are considered together Table 5) derived from mean numbers of casualties per bimonthly period and maximum abundance.

\begin{tabular}{cccccccc}
$\begin{array}{c}\text { Scenario } \\
\text { null }\end{array}$ & $\begin{array}{c}\text { Mean } \\
\text { casualties }\end{array}$ & $\begin{array}{c}\text { Max } \\
\text { abundance }\end{array}$ & & Mort J & Mort A & Survival J Survival A \\
Basic 2030 & 1 & 5680 & 0.00102 & 0.00102 & 0.00102 & 0.60898 & 0.85998 \\
\hline Rekenvariant II & 3 & 5680 & 0.00263 & 0.00263 & 0.00263 & 0.60737 & 0.85837 \\
\hline Rekenvariant III & 4 & 5680 & 0.00348 & 0.00348 & 0.00348 & 0.60652 & 0.85752 \\
\hline Rekenvariant I & 2 & 5680 & 0.00200 & 0.00200 & 0.00200 & 0.60800 & 0.85900 \\
\hline International & 45 & 32199 & 0.00826 & 0.00826 & 0.00826 & 0.60174 & 0.85274 \\
\hline
\end{tabular}

\subsubsection{Diver sp. population level effects}

The estimated additional mortality from habitat loss due to OWFs does not lead to a violation of the ALI set for the diver species. Population growth rates estimated for the national scenarios are similar to the null scenario (Figure 11) and the probability that population abundances lower than the population abundance threshold result from the impact of OWFs is below $3 \%$ for the national scenarios (Table 15).

Table 15. Population growth rates and ALI statistics for diver sp. (Gavia sp., EUring 59; note that redthroated diver and black-throated diver are considered together Table 5). Median and 5\% and 95\% 
quantiles of the population growth rate ('Lambda') distribution are reported. 'P impact' represents the fraction of the distribution of Lambda that is below the threshold of a $30 \%$ smaller population abundance compared to the median lambda of the null scenario after 3 generations, which occurs for a Lambda of 1.002. 'P causality' is the probability that the violation of the threshold results from the impact. 'ALI 0.5' shows whether P causality exceeds 0.5, the ALI threshold (see Table 8).

\begin{tabular}{|c|c|c|c|c|c|c|}
\hline Scenario & $\begin{array}{l}\text { Lambda } \\
\text { median }\end{array}$ & $\begin{array}{l}\text { Lambda } \\
\text { q05 }\end{array}$ & $\begin{array}{l}\text { Lambda } \\
\text { q95 }\end{array}$ & $\begin{array}{c}P \\
\text { impact }\end{array}$ & $\frac{\text { P }}{\text { causality }}$ & ALI 0.5 \\
\hline Null & 1.015 & 0.724 & 1.123 & 0.4572 & & \\
\hline Basic 2030 & 1.014 & 0.726 & 1.122 & 0.4605 & 0.007 & FALSE \\
\hline Rekenvariant II & 1.011 & 0.720 & 1.121 & 0.4679 & 0.023 & FALSE \\
\hline Rekenvariant III & 1.011 & 0.724 & 1.120 & 0.4707 & 0.029 & FALSE \\
\hline Rekenvariant I & 1.012 & 0.723 & 1.121 & 0.4665 & 0.020 & FALSE \\
\hline International & 1.002 & 0.716 & 1.116 & 0.4998 & 0.085 & FALSE \\
\hline
\end{tabular}

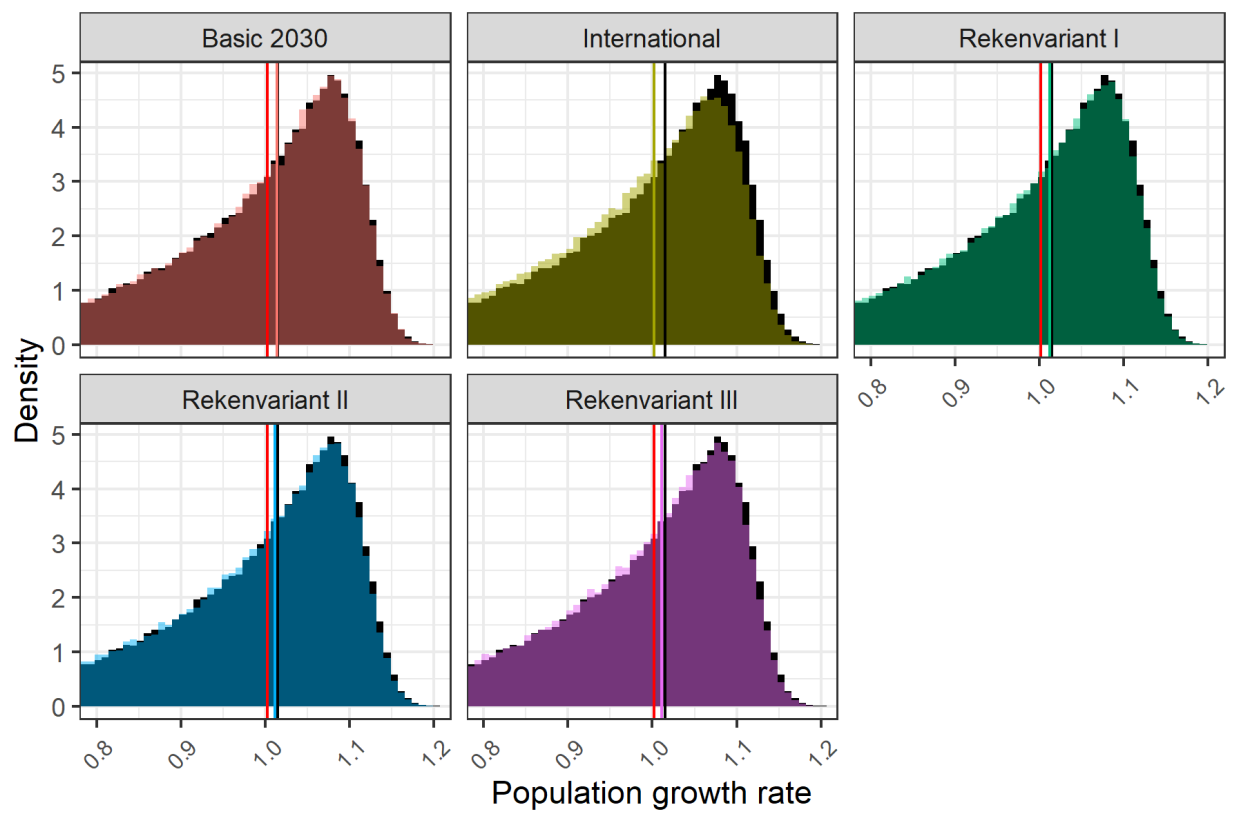

Figure 11. Distribution of population growth rates of diver sp. (Gavia sp., EUring 59; note that redthroated diver and black-throated diver are considered together Table 5) for the different scenarios. Vertical lines indicate the median population growth rates of the ALI threshold (red), the null scenario (black) and each scenario(colours). The distributions for each scenario (in colours) overlay the distribution of the null scenario (in black). 


\subsection{Northern fulmar (Fulmarus glacialis)}

\subsubsection{Northern fulmar habitat loss casualties and mortality}

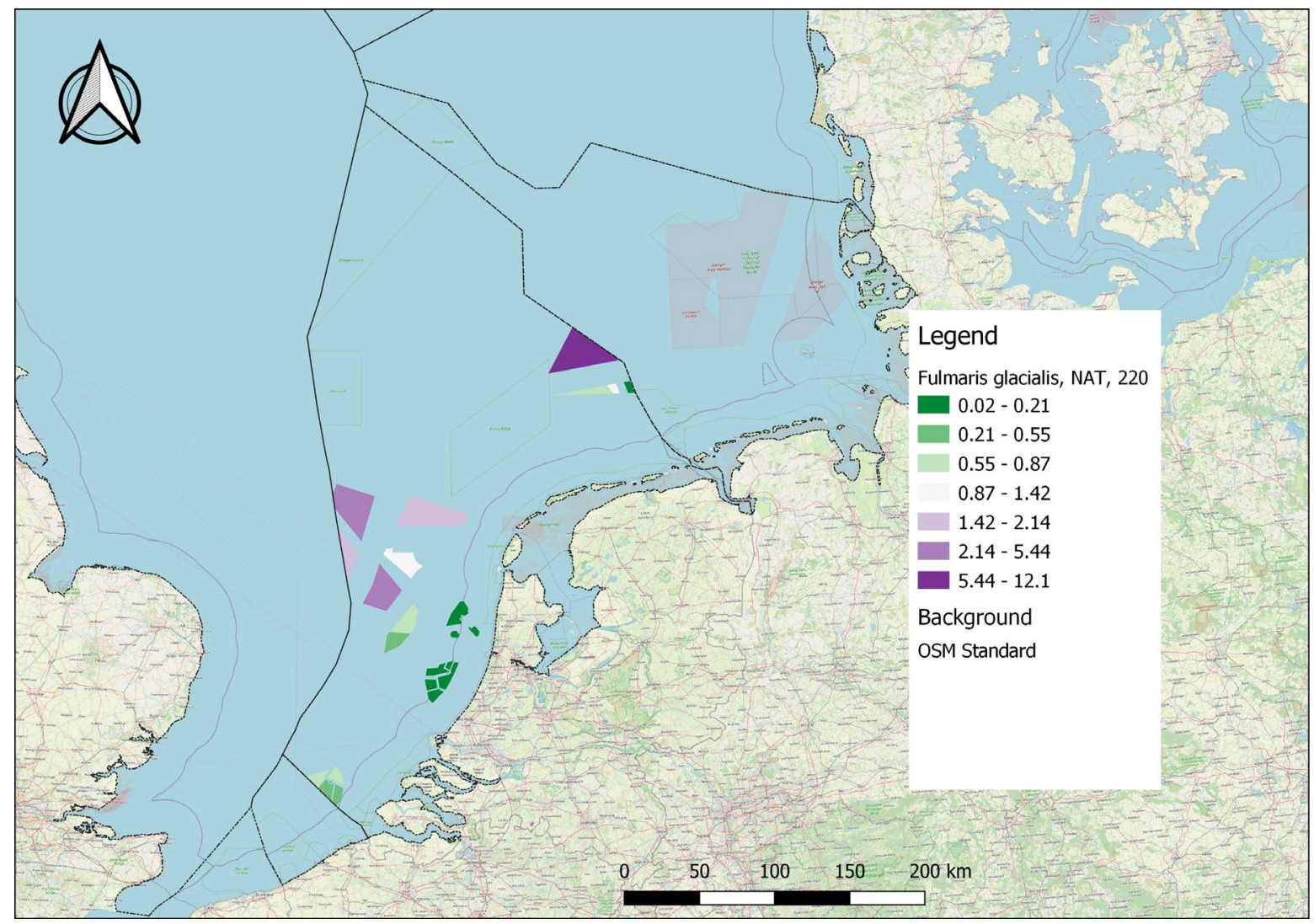

Figure 12. Northern fulmar (Fulmaris glacialis, EUring 220) total annual habitat loss casualties per OWF included in any of the national scenarios.

Most casualties are predicted in the Dutch northern OWF areas further away from the coast (Figure 12). The international map shows a similar picture with most casualties predicted in OWFs far from the coasts towards the central North Sea (Figure 13). Bird density maps of each bimonthly period and of the annual averages can be found in separate documents (Electronic appendices E3 and E4; respectively E3_DensityMaps_19species_NATINT_period.pdf and

E4_DensityMaps_19species_NATINT_yearly.pdf).

The estimated mean number of northern fulmar casualties per bimonthly period varies between 2 and 6 for the national scenarios and is highest for the 'Rekenvariant III' scenario (Table 16). Using the maximum estimated abundance of 50376 individuals, this corresponds to an additional annual mortality of $0.023 \%$ to $0.066 \%$ for the national scenarios (Table 16 ). The estimated mean number of casualties is higher for the 'International' scenario, but because of the large number of northern fulmars in the entire North Sea $(368,439$ individuals), the estimated annual mortality for the international scenario $(0.046 \%$; Table 16$)$ is similar to that of the national scenarios. The number of casualties per bimonthly period for the northern fulmar are shown for each Dutch OWF area in Annex Table 38. 


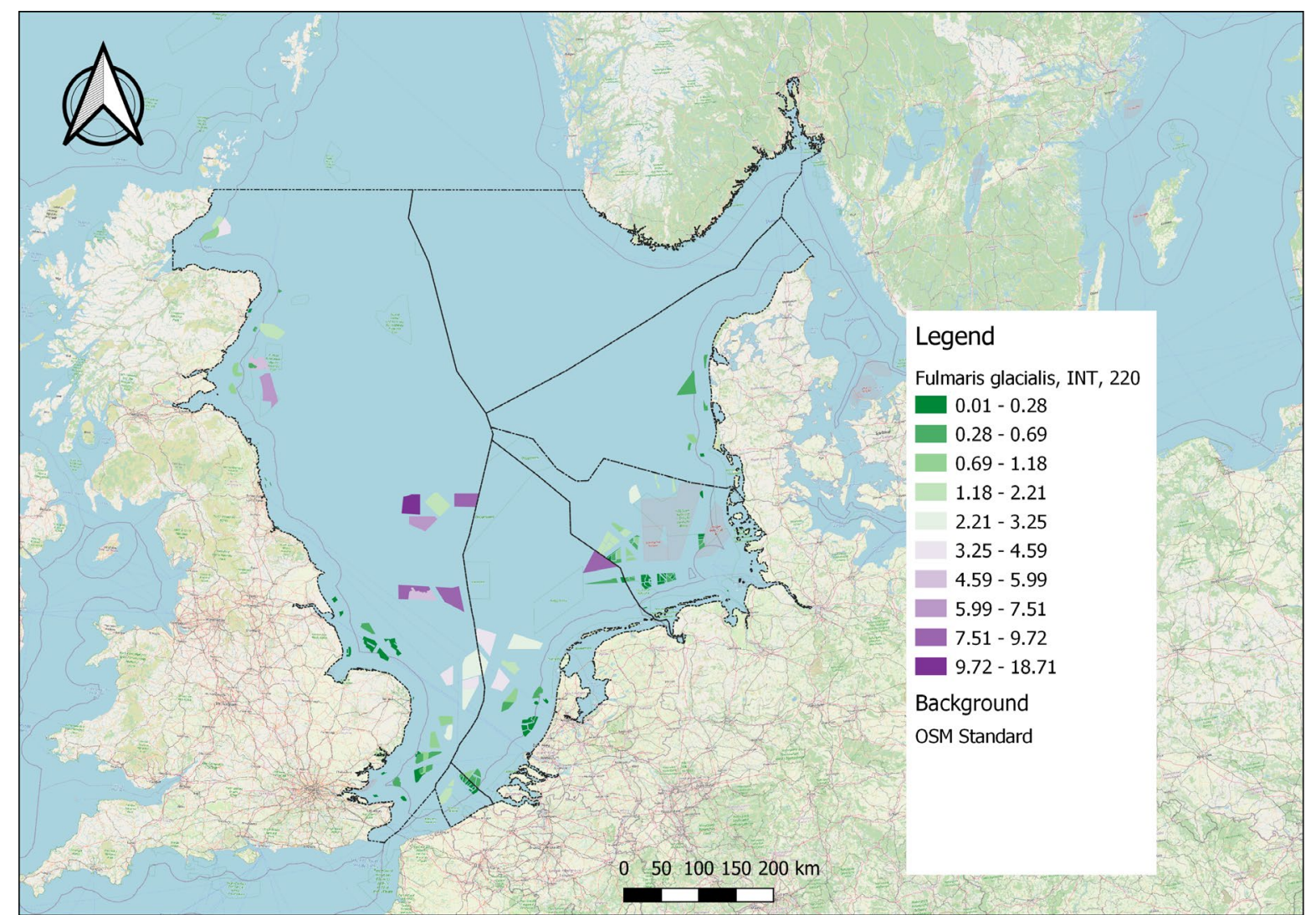

Figure 13. Northern fulmar (Fulmaris glacialis, EUring 220) total annual habitat loss casualties per OWF included in the International scenario.

Table 16. Overall, immature (J) and adult (A) mortality (mort) and survival values mortality and survival values for the northern fulmar (Fulmaris glacialis, EUring 220) derived from mean numbers of casualties per bimonthly period and max abundance

\begin{tabular}{|c|c|c|c|c|c|c|c|}
\hline Scenario & $\begin{array}{l}\text { Mean } \\
\text { casualties }\end{array}$ & $\begin{array}{c}\text { Max } \\
\text { abundance }\end{array}$ & Mort & Mort J & Mort A & Survival & Survival \\
\hline null & & & & & & 0.88400 & 0.93600 \\
\hline Basic 2030 & 2 & 50376 & 0.00023 & 0.00023 & 0.00023 & 0.88377 & 0.93577 \\
\hline Rekenvariant II & 5 & 50376 & 0.00059 & 0.00059 & 0.00059 & 0.88341 & 0.93541 \\
\hline Rekenvariant III & 6 & 50376 & 0.00066 & 0.00066 & 0.00066 & 0.88334 & 0.93534 \\
\hline Rekenvariant I & 5 & 50376 & 0.00055 & 0.00055 & 0.00055 & 0.88345 & 0.93545 \\
\hline International & 29 & 368439 & 0.00046 & 0.00046 & 0.00046 & 0.88354 & 0.93554 \\
\hline
\end{tabular}

\subsubsection{Northern fulmar population level effects}

The estimated additional mortality from habitat loss due to OWFs does not lead to a violation of the ALIs set for the northern fulmar. Population growth rates estimated for all scenarios are similar to the null scenario (Error! Reference source not found.) and the probability that population abundances lower than the population abundance threshold result from the impact of OWFs is below $1.7 \%$ for all scenarios (Table 17). 


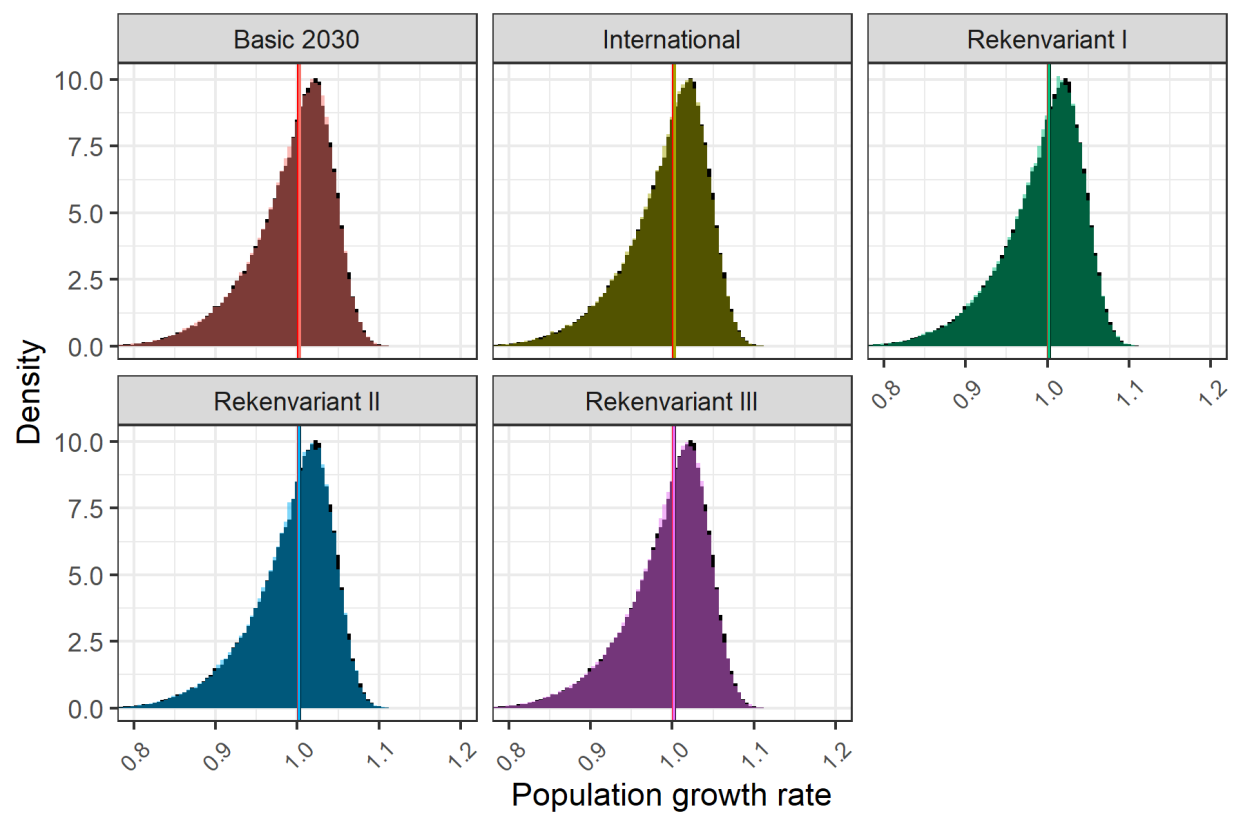

Figure 14. Distribution of population growth rates of the northern fulmar (Fulmaris glacialis, EUring 220) for the different scenarios. Vertical lines indicate the median population growth rates of the ALI threshold (red), the null scenario (black) and each scenario(colours). The distributions for each scenario (in colours) overlay the distribution of the null scenario (in black).

Table 17. Population growth rates and ALI statistics for the northern fulmar (Fulmaris glacialis, EUring 220). Median and $5 \%$ and $95 \%$ quantiles of the population growth rate ('Lambda') distribution are reported. ' $P$ impact' represents the fraction of the distribution of Lambda that is below the threshold of a 15\% smaller population abundance compared to the median lambda of the null scenario after 3 generations, which occurs for a Lambda of 1.001. 'P causality' is the probability that the violation of the population abundance threshold results from the OWF impact. 'ALI 0.1 ' shows whether $P$ causality exceeds 0.1 , the ALI threshold (see Table 8).

\begin{tabular}{ccccccc} 
Scenario & $\begin{array}{c}\text { Lambda } \\
\text { median }\end{array}$ & $\begin{array}{c}\text { Lambda } \\
\text { q } 05\end{array}$ & $\begin{array}{c}\text { Lambda } \\
\text { N } 95\end{array}$ & P impact & P causality & ALI 0.1 \\
\hline Basic 2030 & 1.003 & 0.896 & 1.058 & 0.4808 & & \\
\hline Rekenvariant II & 1.003 & 0.895 & 1.057 & 0.4850 & 0.008 & FALSE \\
\hline Rekenvariant III & 1.002 & 0.896 & 1.057 & 0.4891 & 0.017 & FALSE \\
\hline Rekenvariant I & 1.002 & 0.895 & 1.057 & 0.4888 & 0.016 & FALSE \\
\hline International & 1.002 & 0.897 & 1.057 & 0.4878 & 0.014 & FALSE \\
\hline
\end{tabular}




\subsection{Northern gannet (Morus bassanus)}

\subsubsection{Northern gannet habitat loss casualties and mortality}

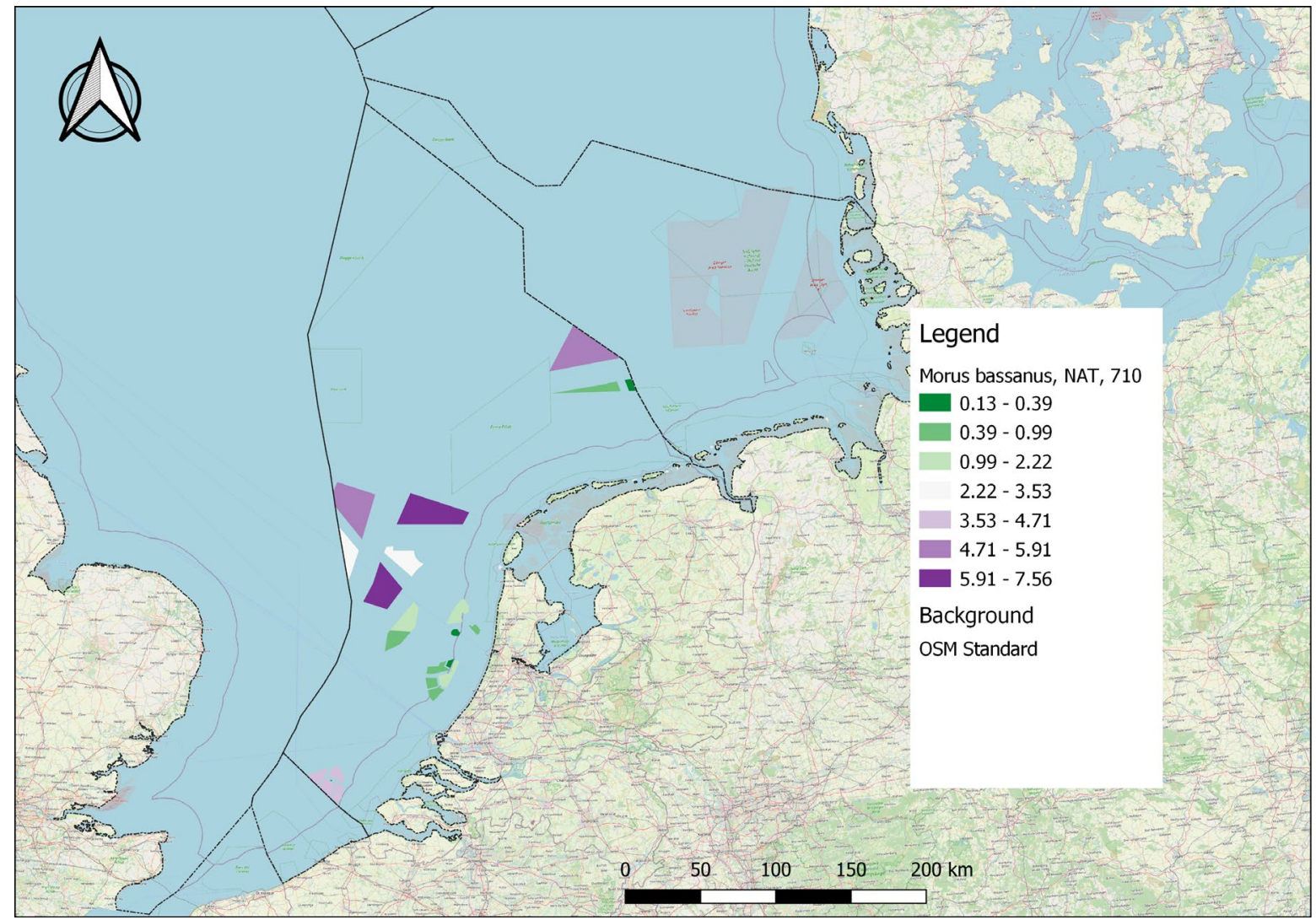

Figure 15. Northern gannet (Morus bassanus, EUring 710) total annual habitat loss casualties per OWF included in the national scenarios.

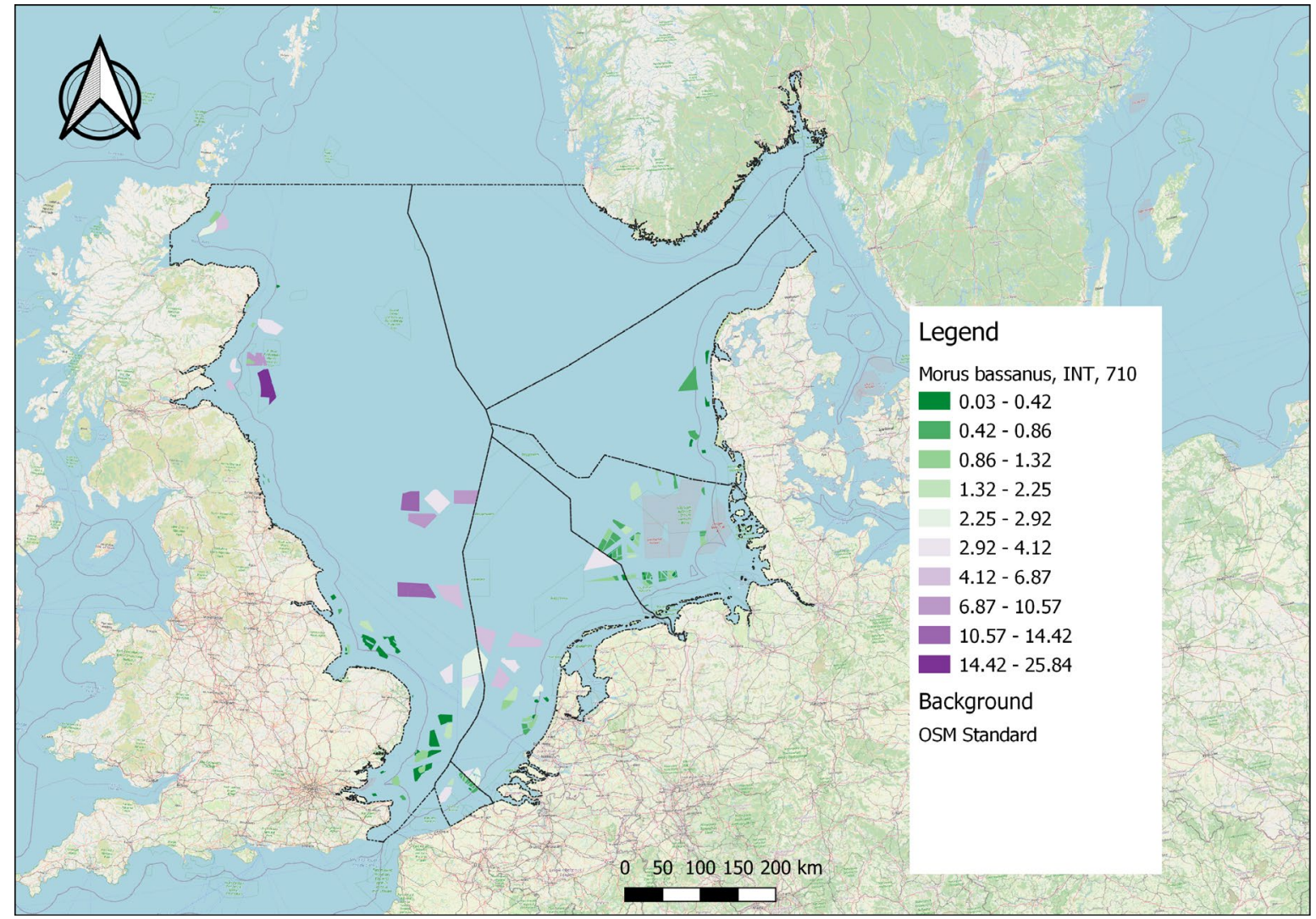

Figure 16. Northern gannet (Morus bassanus, EUring 710) total annual habitat loss casualties per OWF included in the international scenario. 
For the northern gannet, most casualties are predicted in in the Dutch northern OWF areas further away from the coast (Figure 15). The international map shows a similar picture with most casualties predicted in OWF far from the coasts towards the central North Sea (Figure 16). Bird density maps of each bimonthly period and of the annual averages can be found in separate documents (Electronic appendices E3 and E4; respectively E3_DensityMaps_19species_NATINT_period.pdf and E4_DensityMaps_19species_NATINT_yearly.pdf).

The number of northern gannet casualties from both habitat loss and collision risk are presented in Table 18. There are on average between 204 and 332 casualties per bimonthly period from both habitat loss (this study) and collisions (Potiek et al., 2021b) for the national scenarios. For habitat loss alone, this ranges from 7 to 11 . Most casualties are predicted in the 'Rekenvariant III' scenario. The average estimate for the international scenario is 1209 casualties per two months, of which $97 \%$ are collision victims. The number of casualties from habitat loss per bimonthly period for the northern gannet are shown for each Dutch OWF area in Annex Table 38.

The estimated maximum abundance used for the national scenarios equals 31,859 individuals, which leads to an estimated additional mortality rate in between $3.7 \%$ ('Basic 2030') and 6.1\% ('Rekenvariant III') per year, considering both habitat loss and collision risk (Table 18). For the international scenario a maximum abundance of 162,868 individuals is used, which results in an estimated additional mortality of $4.4 \%$ per year. 


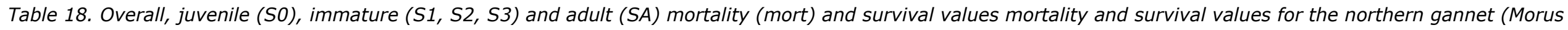

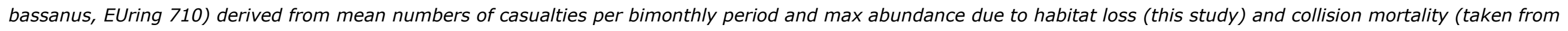

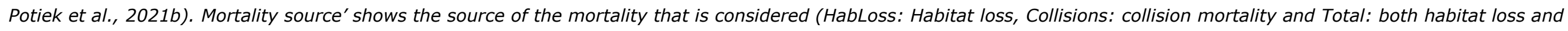
collision mortality together).

\begin{tabular}{|c|c|c|c|c|c|c|c|c|c|c|c|c|c|c|}
\hline Scenario & $\begin{array}{l}\text { Mortality } \\
\text { source }\end{array}$ & $\begin{array}{c}\text { Mean } \\
\text { casua } \\
\text { Ities }\end{array}$ & $\begin{array}{c}\text { Max } \\
\text { abunda } \\
\text { nce }\end{array}$ & Mort & Mort SO & Mort S1 & Mort S2 & Mort S3 & Mort SA & $\begin{array}{c}\text { Survival } \\
\text { S0 }\end{array}$ & $\begin{array}{l}\text { Survival } \\
\text { S1 }\end{array}$ & $\begin{array}{c}\text { Survival } \\
\text { S2 }\end{array}$ & $\begin{array}{c}\text { Survival } \\
\text { S3 }\end{array}$ & $\begin{array}{c}\text { Surviva } \\
\text { SA }\end{array}$ \\
\hline null & & & & & & & & & & 0.48100 & 0.81600 & 0.88400 & 0.88700 & 0.91800 \\
\hline Basic 2030 & $\begin{array}{c}\text { Collision } \\
\mathrm{s}\end{array}$ & 198 & 31859 & 0.03657 & 0.01432 & 0.01372 & 0.02743 & 0.02713 & 0.03570 & 0.46668 & 0.80228 & 0.85657 & 0.85987 & 0.88230 \\
\hline $\begin{array}{l}\text { Basic } 2030 \\
\text { Basic } 2030\end{array}$ & $\begin{array}{l}\text { HabLoss } \\
\text { Total }\end{array}$ & $\begin{array}{c}7 \\
204\end{array}$ & $\begin{array}{l}31859 \\
31859\end{array}$ & $\begin{array}{l}0.00116 \\
0.03770\end{array}$ & $\begin{array}{l}0.00046 \\
0.01477\end{array}$ & $\begin{array}{l}0.00044 \\
0.01414\end{array}$ & $\begin{array}{l}0.00087 \\
0.02828\end{array}$ & $\begin{array}{l}0.00086 \\
0.02796\end{array}$ & $\begin{array}{l}0.00114 \\
0.03680\end{array}$ & $\begin{array}{l}0.48054 \\
0.46623\end{array}$ & $\begin{array}{l}0.81556 \\
0.80186\end{array}$ & $\begin{array}{l}0.88313 \\
0.85572\end{array}$ & $\begin{array}{l}0.88614 \\
0.85904\end{array}$ & $\begin{array}{l}0.91686 \\
0.88120\end{array}$ \\
\hline Rekenvariant II & Collision & 296 & 31859 & 0.05432 & 0.02128 & 0.02037 & 0.04074 & 0.04029 & 0.05302 & 0.45972 & 0.79563 & 0.84326 & 0.84671 & 0.86498 \\
\hline $\begin{array}{l}\text { Rekenvariant II } \\
\text { Rekenvariant II }\end{array}$ & $\begin{array}{l}\text { HabLoss } \\
\text { Total }\end{array}$ & $\begin{array}{c}10 \\
305\end{array}$ & $\begin{array}{l}31859 \\
31859\end{array}$ & $\begin{array}{l}0.00179 \\
0.05603\end{array}$ & $\begin{array}{l}0.00070 \\
0.02195\end{array}$ & $\begin{array}{l}0.00067 \\
0.02101\end{array}$ & $\begin{array}{l}0.00134 \\
0.04202\end{array}$ & $\begin{array}{l}0.00133 \\
0.04156\end{array}$ & $\begin{array}{l}0.00175 \\
0.05469\end{array}$ & $\begin{array}{l}0.48030 \\
0.45905\end{array}$ & $\begin{array}{l}0.81533 \\
0.79499\end{array}$ & $\begin{array}{l}0.88266 \\
0.84198\end{array}$ & $\begin{array}{l}0.88567 \\
0.84544\end{array}$ & $\begin{array}{l}0.91625 \\
0.86331\end{array}$ \\
\hline Rekenvariant III & Collision & 321 & 31859 & 0.05893 & 0.02308 & 0.02210 & 0.04420 & 0.04370 & 0.05751 & 0.45792 & 0.79390 & 0.83980 & 0.84330 & 0.86049 \\
\hline $\begin{array}{l}\text { Rekenvariant III } \\
\text { Rekenvariant III }\end{array}$ & $\begin{array}{l}\text { HabLoss } \\
\text { Total }\end{array}$ & $\begin{array}{l}11 \\
332\end{array}$ & $\begin{array}{l}31859 \\
31859\end{array}$ & $\begin{array}{l}0.00197 \\
0.06080\end{array}$ & $\begin{array}{l}0.00077 \\
0.02381\end{array}$ & $\begin{array}{l}0.00074 \\
0.02280\end{array}$ & $\begin{array}{l}0.00148 \\
0.04560\end{array}$ & $\begin{array}{l}0.00146 \\
0.04510\end{array}$ & $\begin{array}{l}0.00193 \\
0.05935\end{array}$ & $\begin{array}{l}0.48023 \\
0.45719\end{array}$ & $\begin{array}{l}0.81526 \\
0.79320\end{array}$ & $\begin{array}{l}0.88252 \\
0.83840\end{array}$ & $\begin{array}{l}0.88554 \\
0.84190\end{array}$ & $\begin{array}{l}0.91607 \\
0.85865\end{array}$ \\
\hline Rekenvariant I & $\begin{array}{c}\text { Collision } \\
\mathrm{s}\end{array}$ & 282 & 31859 & 0.05189 & 0.02033 & 0.01946 & 0.03892 & 0.03849 & 0.05065 & 0.46067 & 0.79654 & 0.84508 & 0.84851 & 0.86735 \\
\hline $\begin{array}{l}\text { Rekenvariant I } \\
\text { Rekenvariant I }\end{array}$ & $\begin{array}{l}\text { HabLoss } \\
\text { Total }\end{array}$ & $\begin{array}{c}9 \\
291\end{array}$ & $\begin{array}{l}31859 \\
31859\end{array}$ & $\begin{array}{l}0.00169 \\
0.05351\end{array}$ & $\begin{array}{l}0.00066 \\
0.02096\end{array}$ & $\begin{array}{l}0.00063 \\
0.02007\end{array}$ & $\begin{array}{l}0.00127 \\
0.04013\end{array}$ & $\begin{array}{l}0.00125 \\
0.03969\end{array}$ & $\begin{array}{l}0.00165 \\
0.05223\end{array}$ & $\begin{array}{l}0.48034 \\
0.46004\end{array}$ & $\begin{array}{l}0.81537 \\
0.79593\end{array}$ & $\begin{array}{l}0.88273 \\
0.84387\end{array}$ & $\begin{array}{l}0.88575 \\
0.84731\end{array}$ & $\begin{array}{l}0.91635 \\
0.86577\end{array}$ \\
\hline International & $\begin{array}{c}\text { Collision } \\
\mathrm{s}\end{array}$ & 116 & $\begin{array}{c}1628 \\
68\end{array}$ & 0.04223 & 0.01654 & 0.01583 & 0.03167 & 0.03132 & 0.04121 & 0.46446 & 0.80017 & 0.85233 & 0.85568 & 0.87679 \\
\hline International & HabLoss & 42 & $\begin{array}{c}1628 \\
68\end{array}$ & 0.00154 & 0.00060 & 0.00058 & 0.00115 & 0.00114 & 0.00150 & 0.48040 & 0.81542 & 0.88285 & 0.88586 & 0.91650 \\
\hline International & Total & $\begin{array}{c}120 \\
9\end{array}$ & $\begin{array}{c}1628 \\
68\end{array}$ & 0.04371 & 0.01712 & 0.01639 & 0.03278 & 0.03242 & 0.04266 & 0.46388 & 0.79961 & 0.85122 & 0.85458 & 0.87534 \\
\hline
\end{tabular}




\subsubsection{Northern gannet population level effects}
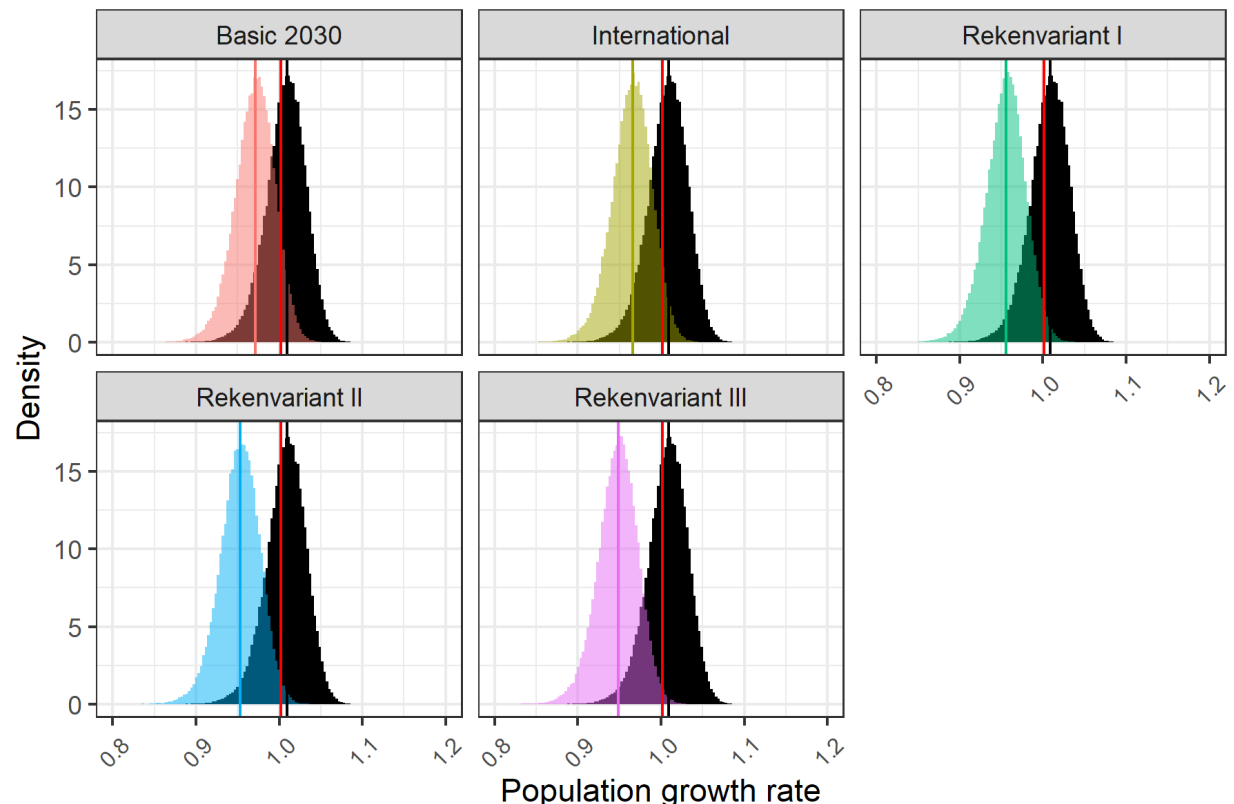

Population growth rate

Figure 17. Distribution of population growth rate of the northern gannet (Morus bassanus, EUring 710) for the different scenarios. Vertical lines indicate the median population growth rates of the ALI threshold (red), the null scenario (black) and each scenario(colours). The distributions for each scenario (in colours) overlay the distribution of the null scenario (in black).

The estimated additional mortality from habitat loss and collisions due to OWFs leads to a violation of the ALI set for the northern gannet (Morus bassanus) for all scenarios (Table 19; Figure 17). The population abundance threshold for the northern gannet is defined as a $30 \%$ smaller population abundance over 3 generations, approximately 46.9 years, compared to a population with no OWFs. The probability that an OWF impact leads to population abundances lower than the population abundance threshold equals $58.8 \%$ for the 'Basic 2030 ' scenario, $62.2 \%$ for the 'Rekenvariant III' scenario and $60.4 \%$ for the 'International' scenario. The acceptable probability is defined at $50 \%$ (Table 8), and the scenario that considers only the OWFs that are already planned thus also exceeds the ALI. With only casualties from habitat loss, violation of the ALI does not occur for any scenario. Considering collision victims alone would already lead to the violation of the ALI for all scenarios. 
Table 19. Population growth rates and ALI statistics for the northern gannet (Morus bassanus, EUring 710). 'Source' shows the source of the OWP effect that is considered (HabLoss: Habitat loss,

Collisions: collision mortality and Total: both habitat loss and collision mortality together). Median and $5 \%$ and $95 \%$ quantiles of the population growth rate ('Lambda') distribution are reported. 'P impact' represents the fraction of the distribution of Lambda that is below the threshold of a 30\% smaller population abundance compared to the median lambda of the null scenario after 3 generations, which occurs for a Lambda of 1.002. ' $P$ causality' is the probability that the violation of the population abundance threshold results from the OWF impact. 'ALI $0.5^{\prime}$ shows whether $P$ causality exceeds 0.5 , the ALI threshold (see Table 8).

\begin{tabular}{cccccccc} 
Scenario & Source & $\begin{array}{c}\text { Lambda } \\
\text { median }\end{array}$ & q05 & q95 & P & P & A A II \\
mull & null & 1.009 & 0.966 & 1.045 & 0.3751 & & \\
\hline Basic 2030 & Collisions & 0.973 & 0.930 & 1.009 & 0.9036 & 0.585 & TRUE \\
\hline Basic 2030 & HabLoss & 1.008 & 0.965 & 1.044 & 0.3944 & 0.049 & FALSE \\
\hline Basic 2030 & Total & 0.972 & 0.929 & 1.008 & 0.9113 & 0.588 & TRUE \\
\hline Rekenvariant II & Collisions & 0.955 & 0.913 & 0.992 & 0.9830 & 0.618 & TRUE \\
\hline Rekenvariant II & HabLoss & 1.007 & 0.964 & 1.043 & 0.4036 & 0.071 & FALSE \\
\hline Rekenvariant II & Total & 0.953 & 0.912 & 0.990 & 0.9860 & 0.620 & TRUE \\
\hline Rekenvariant III & Collisions & 0.951 & 0.908 & 0.987 & 0.9899 & 0.621 & TRUE \\
\hline Rekenvariant III & HabLoss & 1.007 & 0.964 & 1.043 & 0.4076 & 0.080 & FALSE \\
\hline Rekenvariant III & Total & 0.949 & 0.906 & 0.985 & 0.9922 & 0.622 & TRUE \\
\hline Rekenvariant I & Collisions & 0.958 & 0.915 & 0.994 & 0.9766 & 0.616 & TRUE \\
\hline Rekenvariant I & HabLoss & 1.007 & 0.964 & 1.043 & 0.4041 & 0.072 & FALSE \\
\hline Rekenvariant I & Total & 0.956 & 0.914 & 0.993 & 0.9808 & 0.618 & TRUE \\
\hline International & Collisions & 0.967 & 0.925 & 1.004 & 0.9397 & 0.601 & TRUE \\
\hline International & HabLoss & 1.008 & 0.965 & 1.043 & 0.3999 & 0.062 & FALSE \\
\hline International & Total & 0.966 & 0.924 & 1.002 & 0.9474 & 0.604 & TRUE \\
\hline
\end{tabular}

\subsection{Great cormorant (Phalacrocorax carbo)}

\subsubsection{Great cormorant habitat loss casualties and mortality}

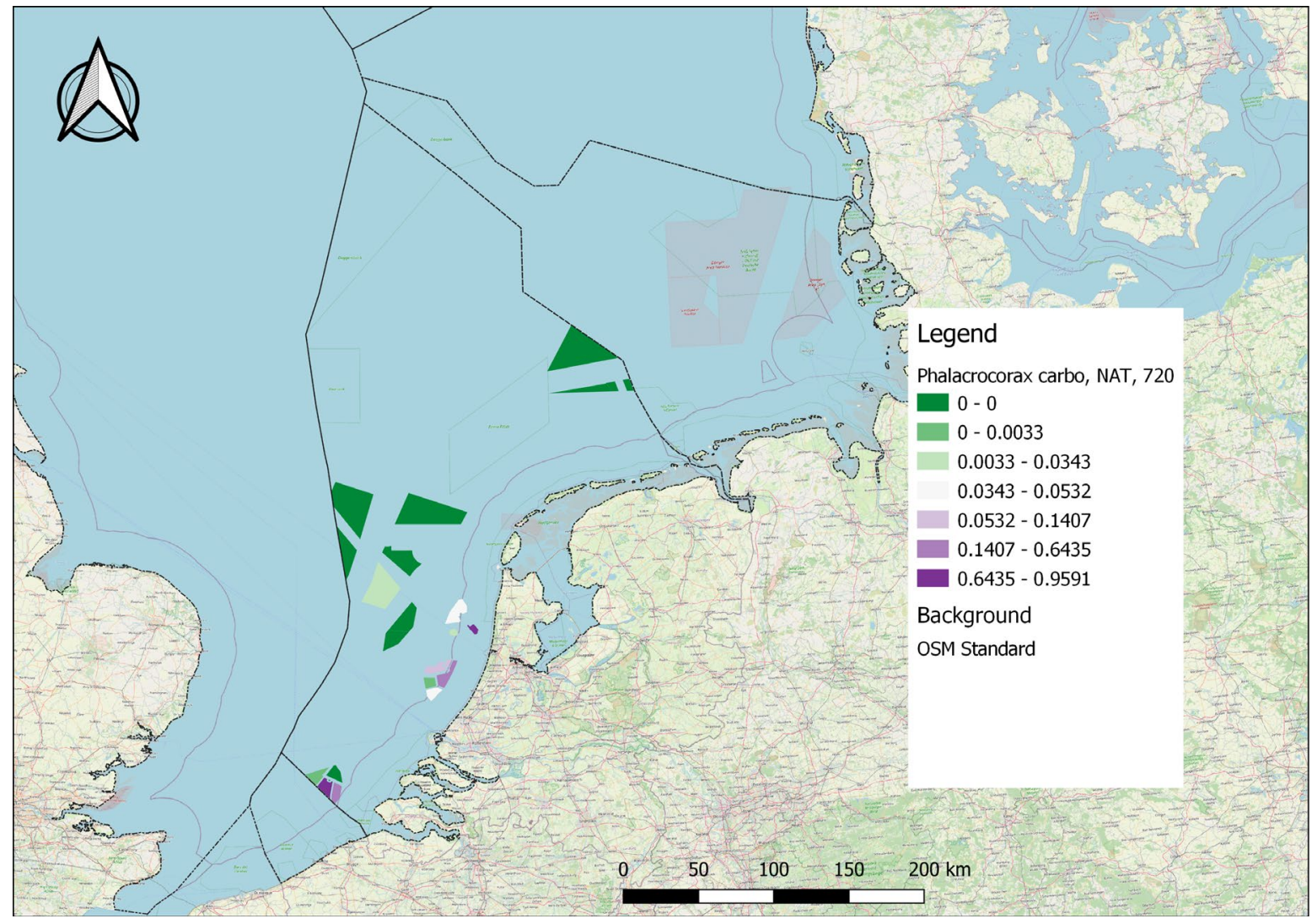

Figure 18. Great cormorant (Phalacrocorax carbo, EUring 720) total annual habitat loss casualties per OWF included in the national scenarios. 


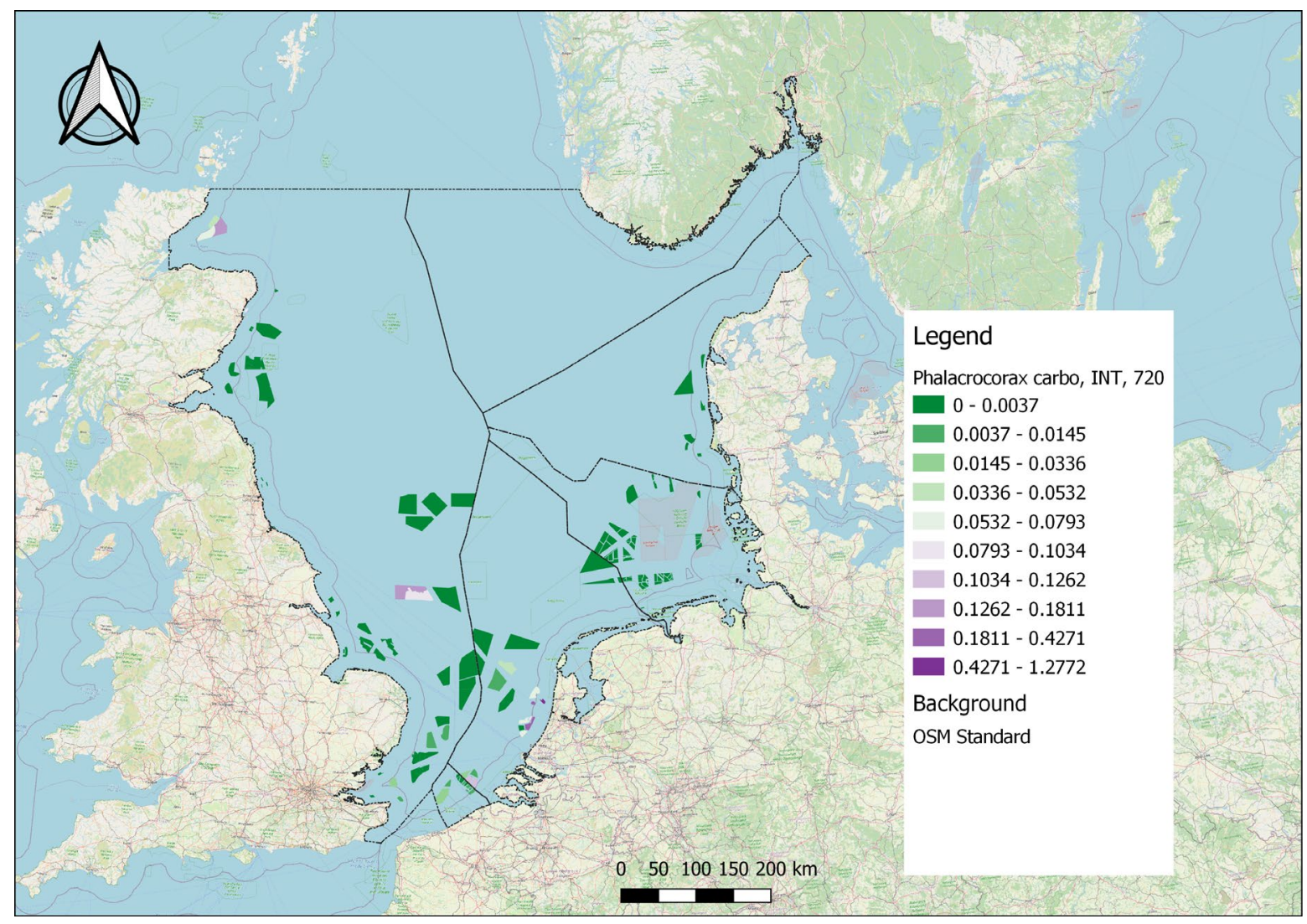

Figure 19. Great cormorant (Phalacrocorax carbo, EUring 720) total annual habitat loss casualties per OWF included in the international scenario.

For the great cormorant, predicted casualties are overall very low. Most Dutch casualties are predicted in the Dutch OWF areas along the coast (Figure 18). In an international context, the spatial pattern is similar (Figure 19), with few victims in most areas and slightly more predicted victims in small areas along the Scottish coast, one area central to the UK EEZ and along the Dutch coast. Bird density maps of each bimonthly period and of the annual averages can be found in separate documents (Electronic appendices E3 and E4; respectively E3_DensityMaps_19species_NATINT_period.pdf and E4_DensityMaps_19species_NATINT_yearly.pdf).

The estimated mean number of great cormorant casualties per bimonthly period is around 1 individual for all scenarios (Table 20). Note that there is no difference in the number of casualties between the national scenarios. Thus, the effect of the new national OWF areas on habitat loss seems negligible as the mean number of casualties does not increase for the scenarios with new OWF areas compared to the scenario with the OWFs that are already planned. With the maximum estimated abundances, the estimated numbers of casualties correspond to an additional mortality rate of $0.12 \%$ and $0.09 \%$ per year for the national and international scenarios, respectively (Table 20). The number of casualties per bimonthly period for the great cormorant are shown for each Dutch OWF area in Annex Table 38.

Table 20. mortality for the great cormorant (Phalacrocorax carbo, EUring 720) derived from mean numbers of casualties per bimonthly period and maximum abundance.

\begin{tabular}{cccc} 
Scenario & Mean casualties & Max abundance & mort \\
Basic 2030 & 1 & 2621 & 0.0012462 \\
\hline Rekenvariant II & 1 & 2621 & 0.0012462 \\
\hline Rekenvariant III & 1 & 2621 & 0.0012462 \\
\hline Rekenvariant I & 1 & 2621 & 0.0012462 \\
\hline International & 1 & 3822 & 0.0009098
\end{tabular}




\subsection{Common eider (Somateria mollissima)}

\subsubsection{Common eider habitat loss casualties and mortality}

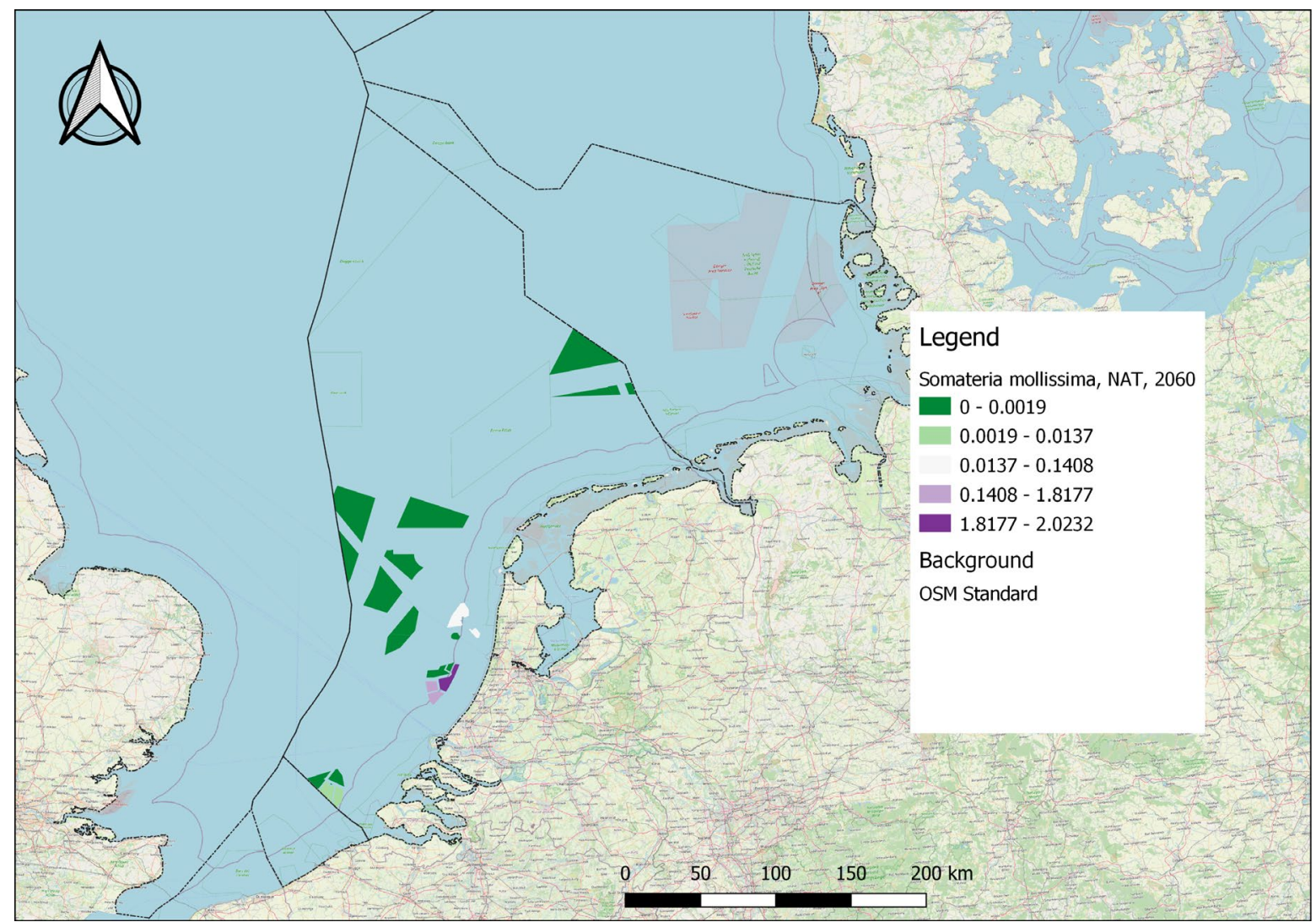

Figure 20. Common eider (Somateria mollissima, EUring 2060) total annual habitat loss casualties per OWF included in the national scenarios.

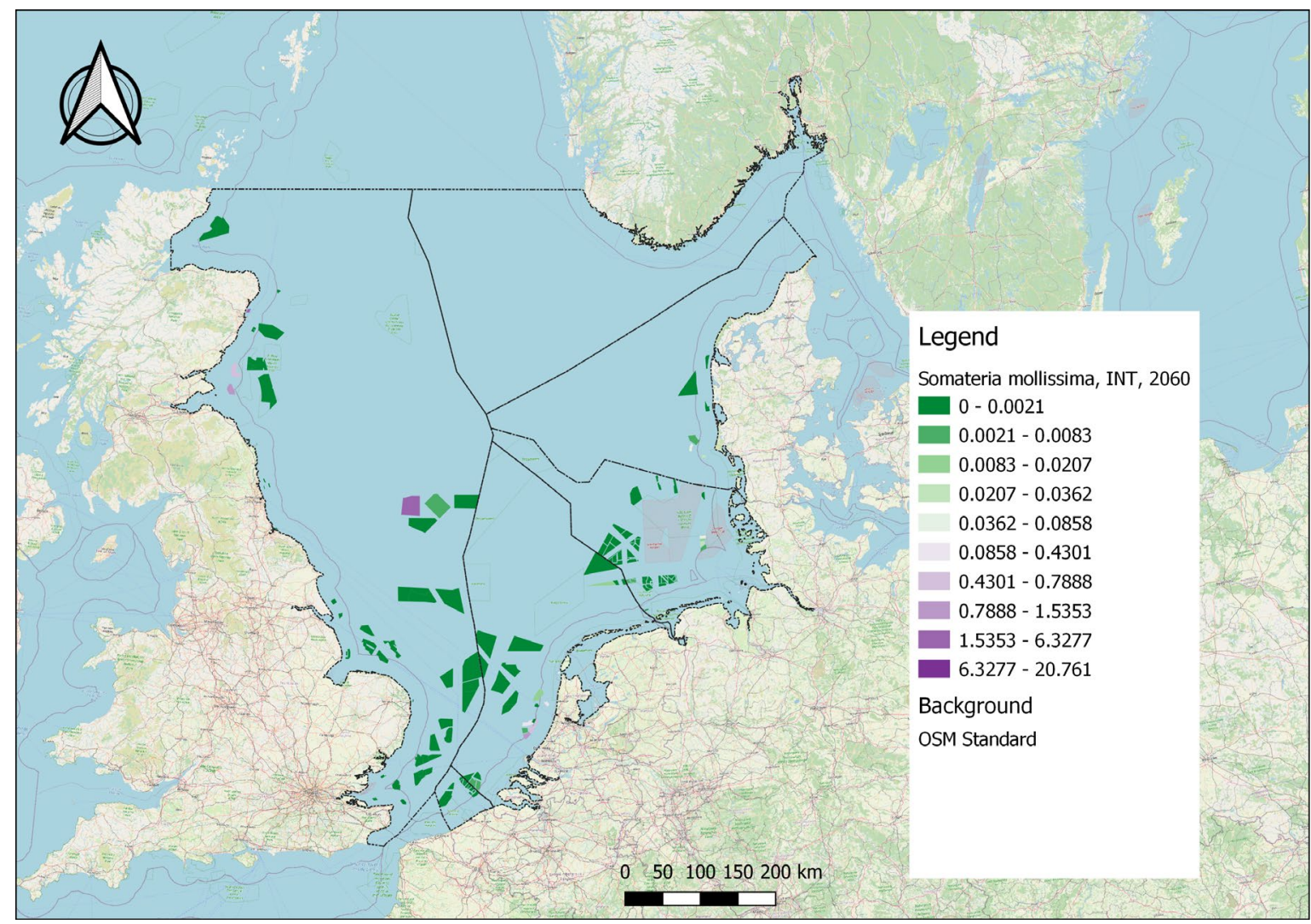

Figure 21. Common eider (Somateria mollissima, EUring 2060) total annual habitat loss casualties per OWF included in the international scenario. 
For the common eider, predicted casualties are overall very low. Most Dutch casualties are predicted in the Dutch OWF areas along the coast (Figure 20). In an international context, the spatial pattern is similar (Figure 21), with few victims in most areas and slightly more predicted victims in small areas along the southern Scottish coast, one area central to the UK EEZ and along the German and Dutch coasts. Bird density maps of each bimonthly period and of the annual averages can be found in separate documents (Electronic appendices E3 and E4; respectively

E3_DensityMaps_19species_NATINT_period.pdf and E4_DensityMaps_19species_NATINT_yearly.pdf).

The estimated mean number of common eider casualties per bimonthly period is around 0.7 individuals for the national scenarios and 5.7 for the international scenario (Table 21). Note that there is no difference in the number of casualties between the national scenarios. Thus, the effect of the new national OWF areas on habitat loss seems negligible as the mean number of casualties does not increase for the scenarios with new OWF areas compared to the scenario with the OWFs that are already planned. With the maximum estimated abundance the estimated number of casualties results in an additional mortality rate for the national scenarios of $0.019 \%$ per year (Table 21 ). For the international scenario the estimated additional mortality is $0.03 \%$ per year. The number of casualties per bimonthly period for the common eider are shown for each Dutch OWF area in Annex Table 38.

Table 21. Mortality for the common eider (Somateria mollissima, EUring 2060) derived from mean numbers of casualties per bimonthly period and maximum abundance

\begin{tabular}{cccc} 
Scenario & Mean casualties & Max abundance & mort \\
Basic 2030 & 1 & 22134 & 0.0001958 \\
\hline Rekenvariant II & 1 & 22134 & 0.0001958 \\
\hline Rekenvariant III & 1 & 22134 & 0.0001958 \\
\hline Rekenvariant I & 1 & 22134 & 0.0001958 \\
\hline International & 6 & 96653 & 0.0003546
\end{tabular}

\subsection{Common scoter (Melanitta nigra)}

\subsubsection{Common scoter habitat loss casualties and mortality}

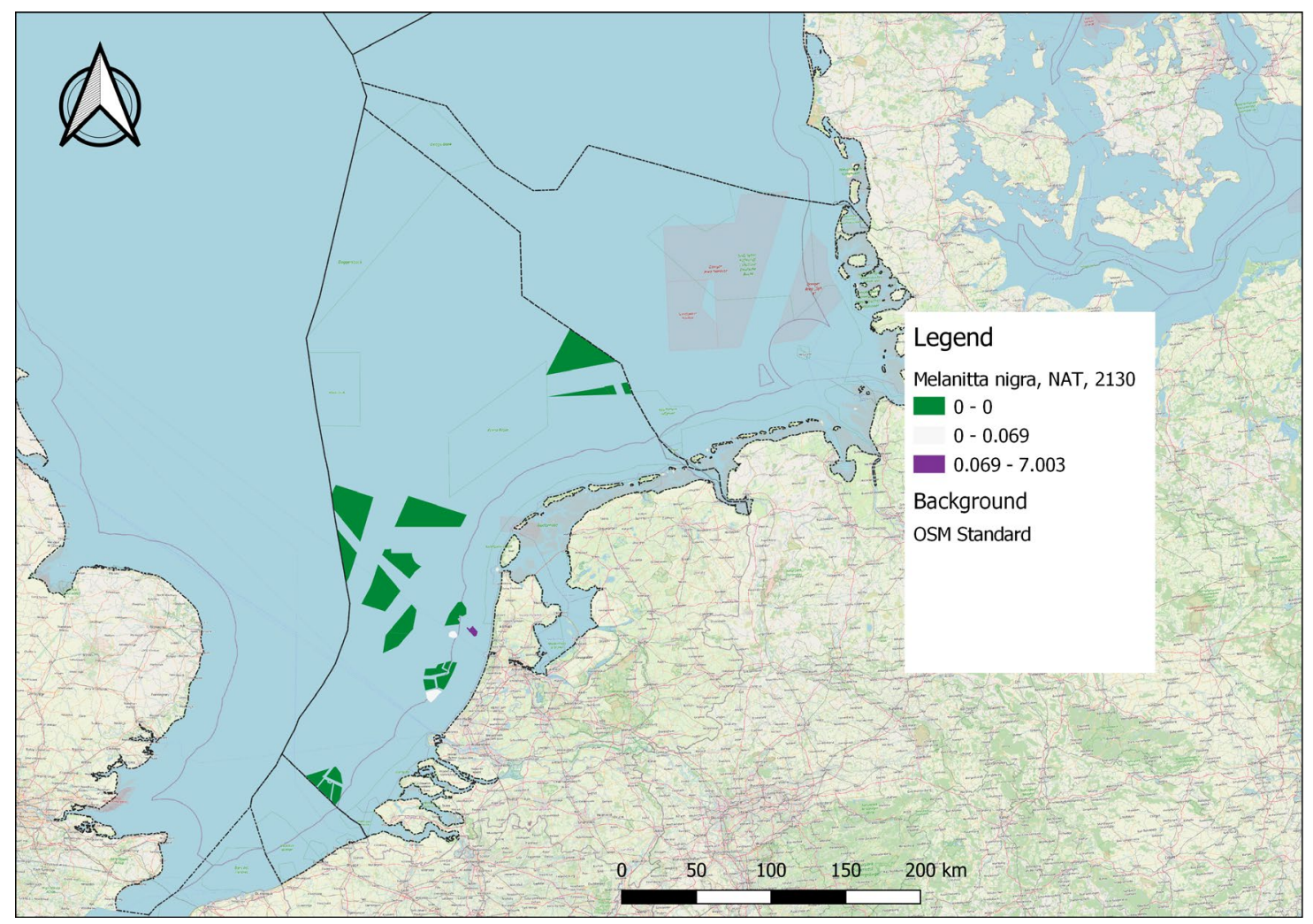

Figure 22. Common scoter (Melanitta nigra, EUring 2130) total annual habitat loss casualties per OWF included in the national scenarios. 


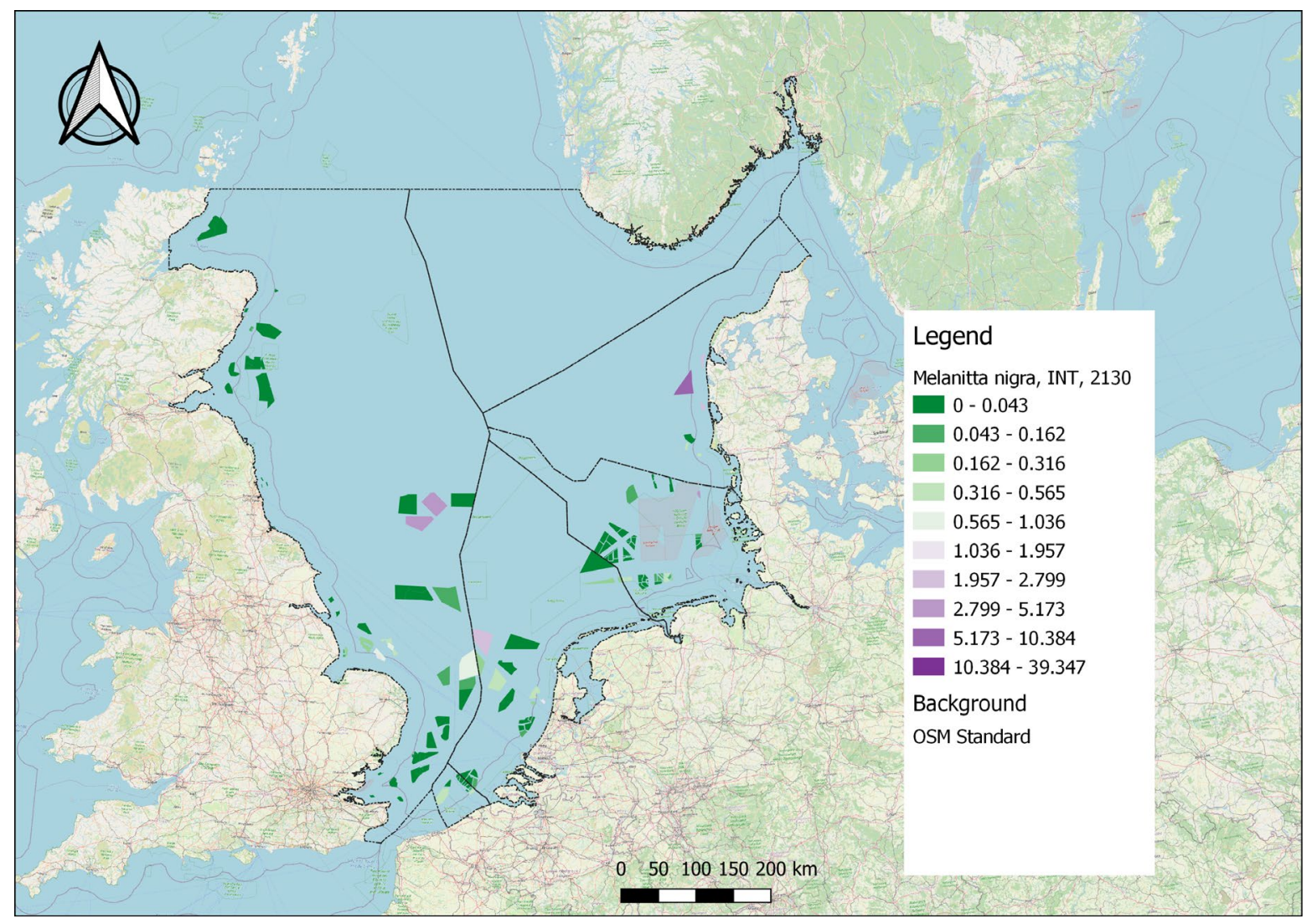

Figure 23. Common scoter (Melanitta nigra, EUring 2130) total annual habitat loss casualties per OWF included in the international scenario.

For the common scoter, predicted casualties are overall very low. Most Dutch casualties are predicted in some Dutch OWF areas along the coast (Figure 22). In an international context, the spatial pattern is slightly different (Figure 23), few victims are predicted in most areas and some areas have more predicted victims, mostly central to the North Sea and at one spot along the Danish coast. Bird density maps of each bimonthly period and of the annual averages can be found in separate documents (Electronic appendices E3 and E4; respectively E3_DensityMaps_19species_NATINT_period.pdf and E4_DensityMaps_19species_NATINT_yearly.pdf).

The estimated mean number of common scoter casualties per bimonthly period is around 2 individuals for the national scenarios and 15 for the international scenario (Table 22). Note that there is no difference in the number of casualties between the national scenarios. Thus, the effect of the new national OWF areas on habitat loss seems negligible as the mean number of casualties does not increase for the scenarios with new OWF areas compared to the scenario with the OWFs that are already planned. With the maximum estimated abundance (Table 22), the estimated number of casualties results in an additional mortality rate for the national scenarios of $0.014 \%$ per year (Table 22 ). For the international scenario the estimated addition mortality is $0.015 \%$ per year. The number of casualties per bimonthly period for the common scoter are shown for each Dutch OWF area in Annex Table 38.

Table 22. Mortality for the common scoter (Melanitta nigra, EUring 2130) derived from mean numbers of casualties per bimonthly period and maximum abundance

\begin{tabular}{cccc} 
Scenario & Mean casualties & Max abundance & mort \\
Basic 2030 & 2 & 51166 & 0.0001382 \\
\hline Rekenvariant II & 2 & 51166 & 0.0001382 \\
\hline Rekenvariant III & 2 & 51166 & 0.0001382 \\
\hline Rekenvariant I & 2 & 51166 & 0.0001382 \\
International & 15 & 598905 & 0.0001456 \\
\hline
\end{tabular}




\subsection{Sandwich tern (Thalasseus sandvicensis)}

4.9.1 Sandwich tern habitat loss casualties and mortality

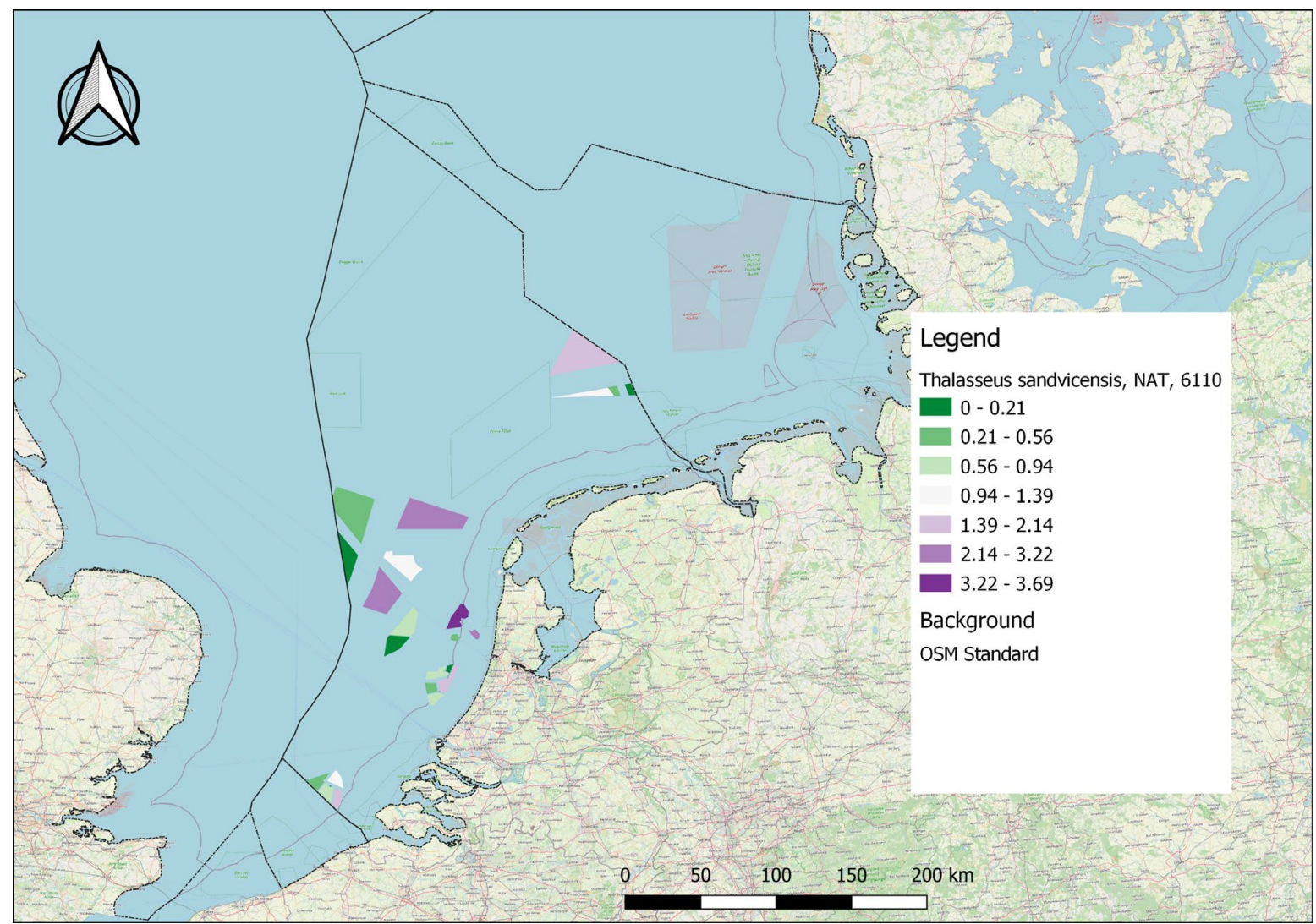

Figure 24. Sandwich tern (Thalasseus sandvicensis, EUring 6110) total annual habitat loss casualties per OWF included in the national scenarios. 


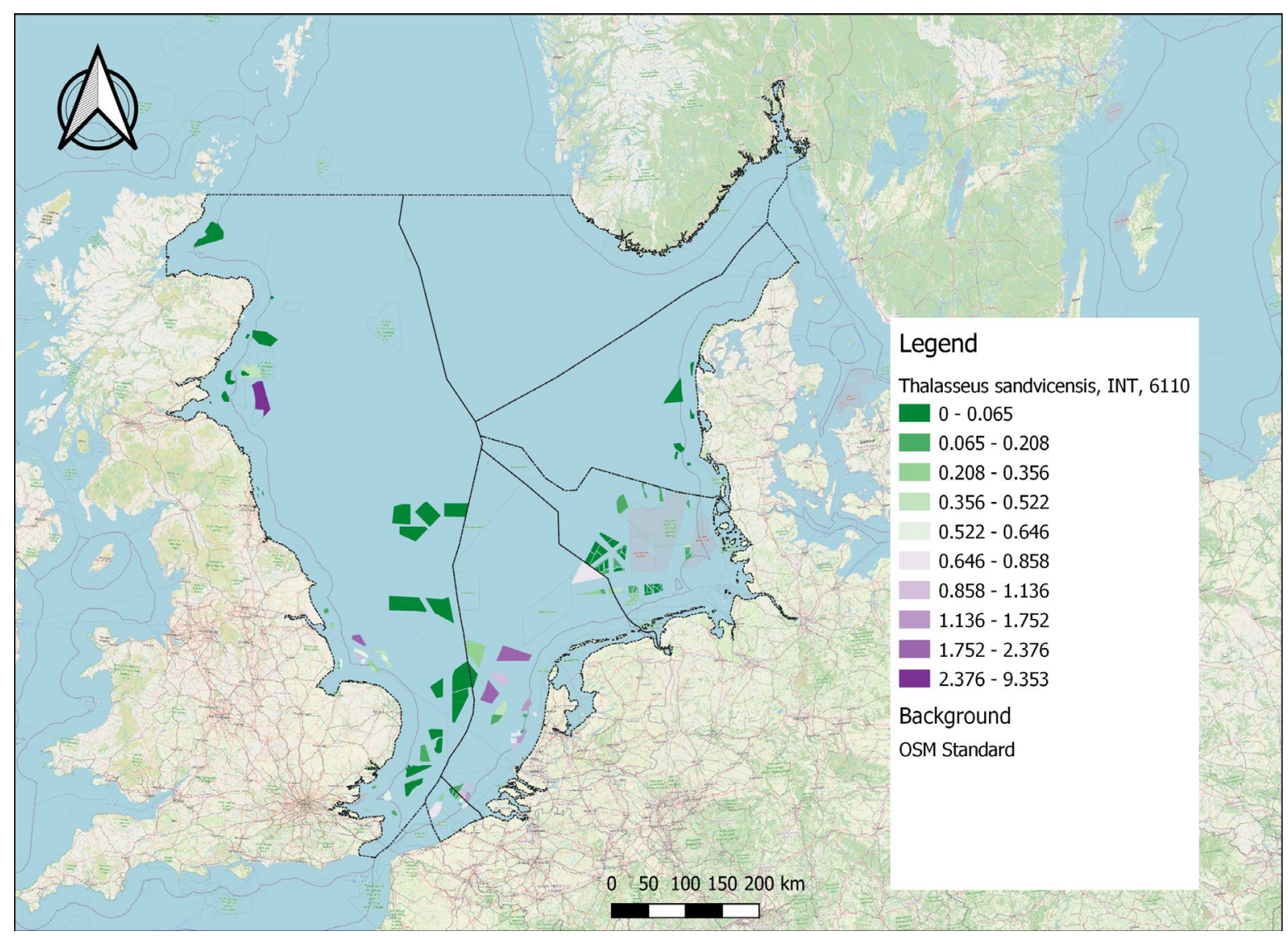

Figure 25. Sandwich tern (Thalasseus sandvicensis, EUring 6110) total annual habitat loss casualties per OWF included in the international scenario.

For the sandwich tern, most Dutch casualties are predicted in the Dutch OWF areas along the coast (Figure 24), but also in some of the areas further from the coast, such as "IJmuiden Ver" (OWF bw6), "Zoekgebied 5 Oost" (OWF - 2630) and "Hollandse Kust Noord" (OWF - 15). The international map shows a similar pattern, with few casualties predicted in international waters except for some areas along the UK and Belgian coasts (Figure 25). Bird density maps of each bimonthly period and of the annual averages can be found in separate documents (Electronic appendices E3 and E4; respectively E3_DensityMaps_19species_NATINT_period.pdf and E4_DensityMaps_19species_NATINT_yearly.pdf).

The number of sandwich tern casualties from both habitat loss (this study) and collision risk (Potiek et al., 2021b) are presented in Table 23. There are on average in between 9 and 12 casualties per bimonthly period from both habitat loss and collisions for the national scenarios, with most casualties in the 'Rekenvariant III' scenario. The average estimate for the international scenario is 19 casualties per two months, of which $58 \%$ are collision victims. The number of casualties from habitat loss per bimonthly period for the sandwich tern are shown for each Dutch OWF area in Annex Table 38.

The estimated maximum abundance used for the national scenarios equals 22,603 individuals, which leads to an estimated additional mortality rate in between $0.23 \%$ ('Basic 2030') and $0.30 \%$ ('Rekenvariant III') per year, for both habitat loss and collision risk (Table 23). The international scenario uses maximum abundance of 25,882 individuals, which results in an estimated additional mortality of $0.43 \%$ per year. From Table 23 it can be seen that the additional OWF mortality is only applied to the adult life stages $A_{34}$ and $A_{B}$, which share survival parameter $S_{A}$. Survival of the immature life stages (age $0-2$ ) is unaffected by OWF-induced mortality in the geographical context of the southern North Sea. 


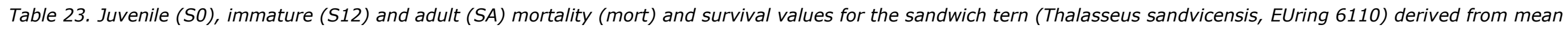

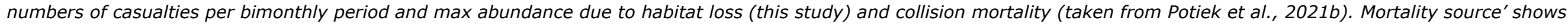

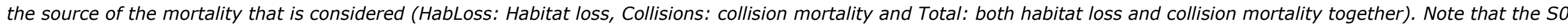
and $\mathrm{S} 12$ survival do not change and were therefore not included in the table.

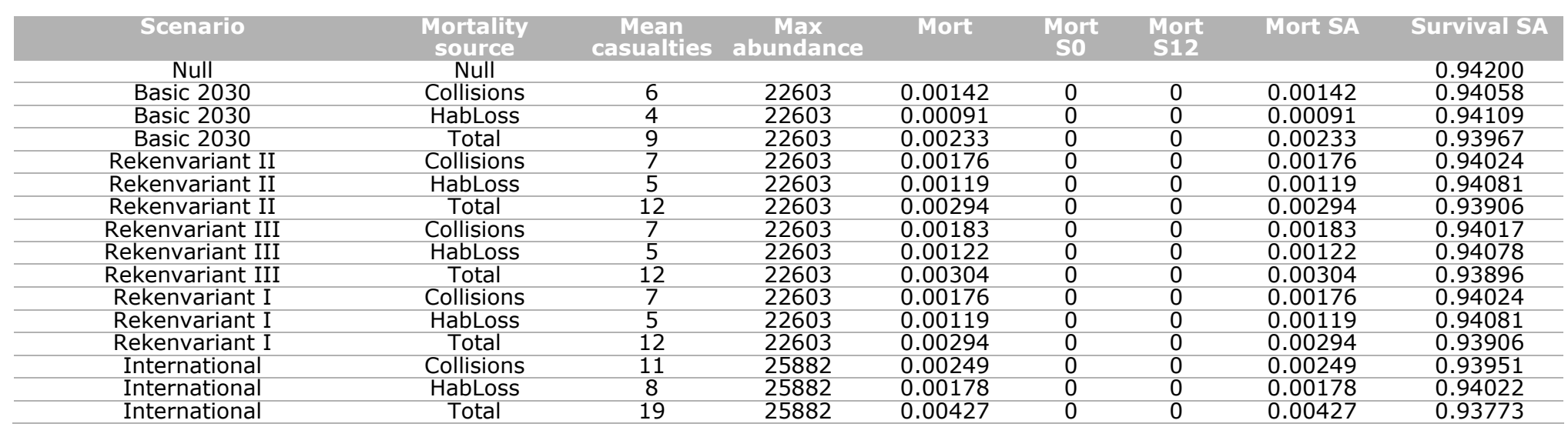




\subsubsection{Sandwich tern population level effects}

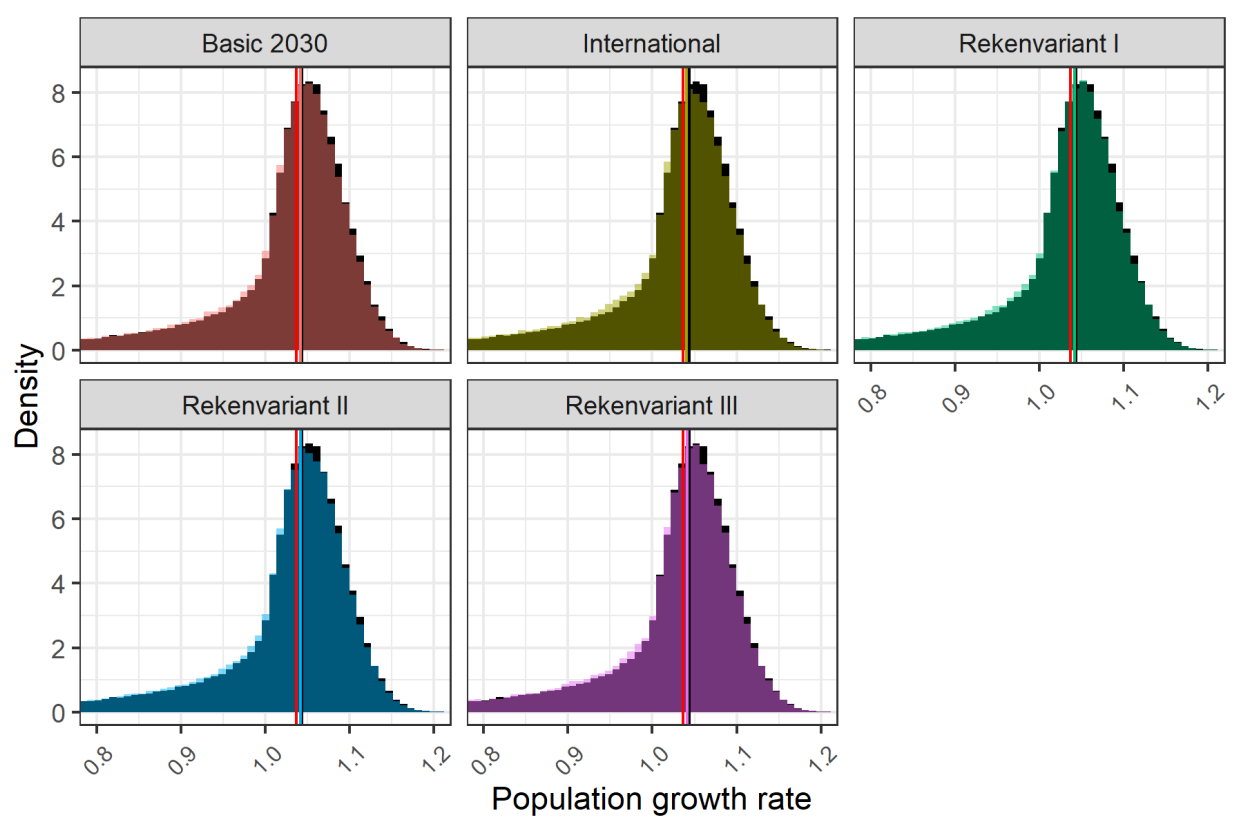

Figure 26. Distribution of population growth rate of the sandwich tern (Thalasseus sandvicensis, EUring 6110) for the different scenarios. Vertical lines indicate the median population growth rates of the ALI threshold (red), the null scenario (black) and each scenario(colours). The distributions for each scenario (in colours) overlay the distribution of the null scenario (in black).

The estimated additional mortality from habitat loss and collision mortality due to OWFs does not lead to a violation of the ALI set for the sandwich tern. Median population growth rates estimated for the national scenarios range between 1.040 and 1.043 (Table 24). Population growth rates estimated for all scenarios are similar to the null scenario (Figure 26). The probability that a violation of the population abundance threshold results from an OWF-induced impact ranges between 3.7 to $4.1 \%$ for the national scenarios and equals $5.7 \%$ for the international scenario (Table 24 ).

Table 24. Population growth rate and ALI statistics for the sandwich tern (Thalasseus sandvicensis, EUring 6110). Source' shows the source of the OWP effect that is considered (HabLoss: Habitat loss, Collisions: collision mortality and Total: both habitat loss and collision mortality together). Median and $5 \%$ and $95 \%$ quantiles of the population growth rate ('Lambda') distribution are reported. ' $P$ impact' represents the fraction of the distribution of Lambda that is below the threshold of a 30\% smaller population abundance compared to the median lambda of the null scenario after 3 generations, which occurs for a Lambda of 1.037. ' $P$ causality' is the probability that the violation of the population abundance threshold results from the OWF impact. 'ALI $0.5^{\prime}$ shows whether $P$ causality exceeds 0.5 , the ALI threshold (see Table 8).

\begin{tabular}{|c|c|c|c|c|c|c|c|}
\hline Scenarto & Source & Lambda median & 905 & q95 & P impact & P causality & ALI 0.5 \\
\hline Null & null & 1.044 & 0.805 & 1.118 & 0.4436 & & \\
\hline Basic 2030 & Collisions & 1.043 & 0.805 & 1.117 & 0.4530 & 0.021 & FALSE \\
\hline Basic 2030 & HabLoss & 1.043 & 0.798 & 1.118 & 0.4512 & 0.017 & FALSE \\
\hline Basic 2030 & Total & 1.041 & 0.801 & 1.117 & 0.4610 & 0.038 & FALSE \\
\hline Rekenvariant II & Collisions & 1.042 & 0.803 & 1.117 & 0.4561 & 0.027 & FALSE \\
\hline Rekenvariant II & HabLoss & 1.043 & 0.802 & 1.117 & 0.4528 & 0.020 & FALSE \\
\hline Rekenvariant II & Total & 1.041 & 0.804 & 1.117 & 0.4628 & 0.041 & FALSE \\
\hline Rekenvariant III & Collisions & 1.042 & 0.803 & 1.117 & 0.4566 & 0.028 & FALSE \\
\hline Rekenvariant III & HabLoss & 1.042 & 0.801 & 1.117 & 0.4535 & 0.022 & FALSE \\
\hline Rekenvariant III & Total & 1.042 & 0.803 & 1.117 & 0.4609 & 0.037 & FALSE \\
\hline Rekenvariant I & Collisions & 1.042 & 0.803 & 1.117 & 0.4538 & 0.022 & FALSE \\
\hline Rekenvariant I & HabLoss & 1.043 & 0.803 & 1.118 & 0.4521 & 0.019 & FALSE \\
\hline Rekenvariant I & Total & 1.042 & 0.804 & 1.117 & 0.4606 & 0.037 & FALSE \\
\hline International & Collisions & 1.042 & 0.805 & 1.117 & 0.4596 & 0.035 & FALSE \\
\hline International & HabLoss & 1.042 & 0.802 & 1.118 & 0.4549 & 0.025 & FALSE \\
\hline International & Total & 1.040 & 0.800 & 1.116 & 0.4703 & 0.057 & FALSE \\
\hline
\end{tabular}




\subsection{Common guillemot (Uria aalge)}

4.10.1 Common guillemot habitat loss casualties and mortality

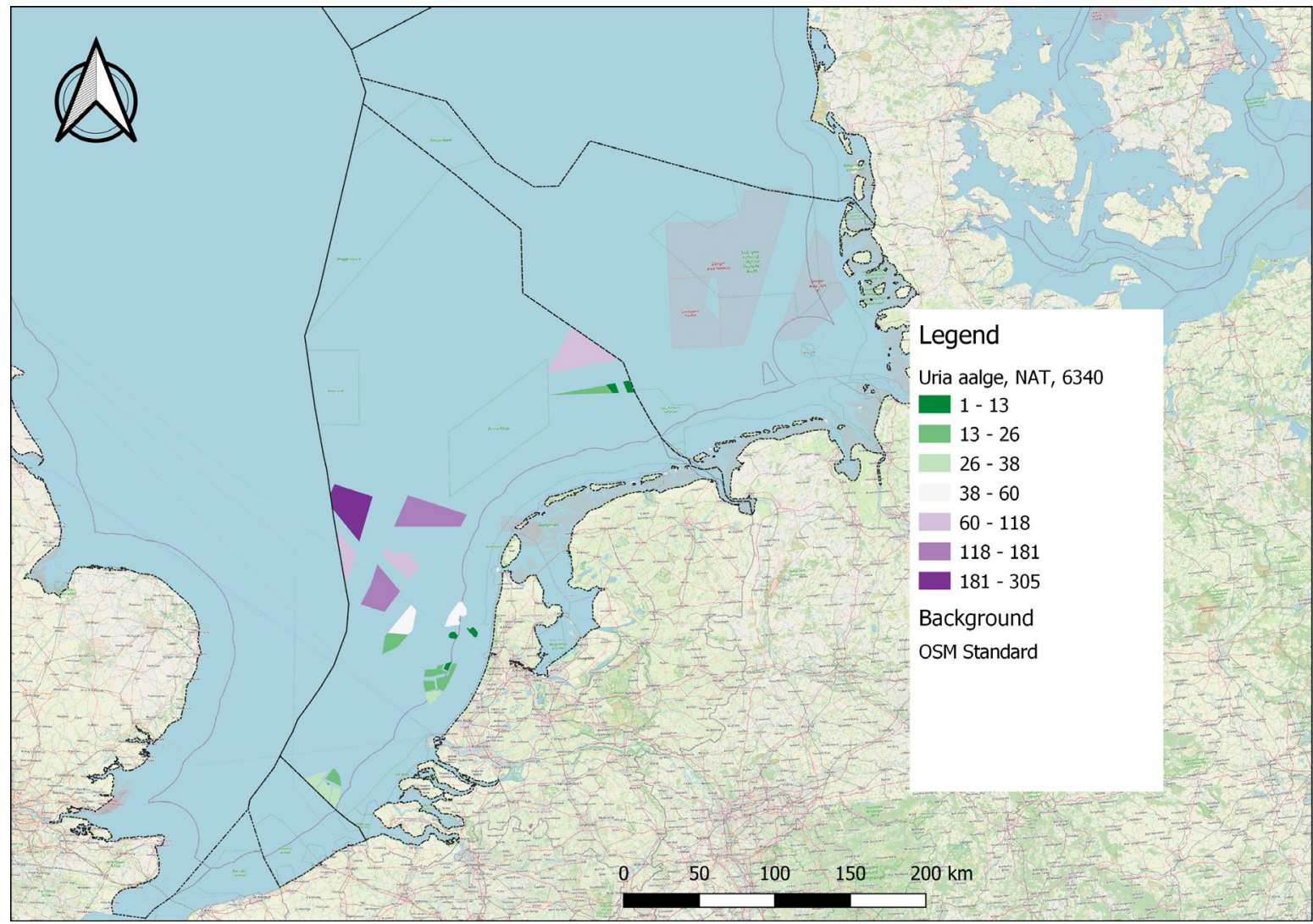

Figure 27. Common guillemot (Uria aalge, EUring 6340) total annual habitat loss casualties per OWF included in the national scenarios.

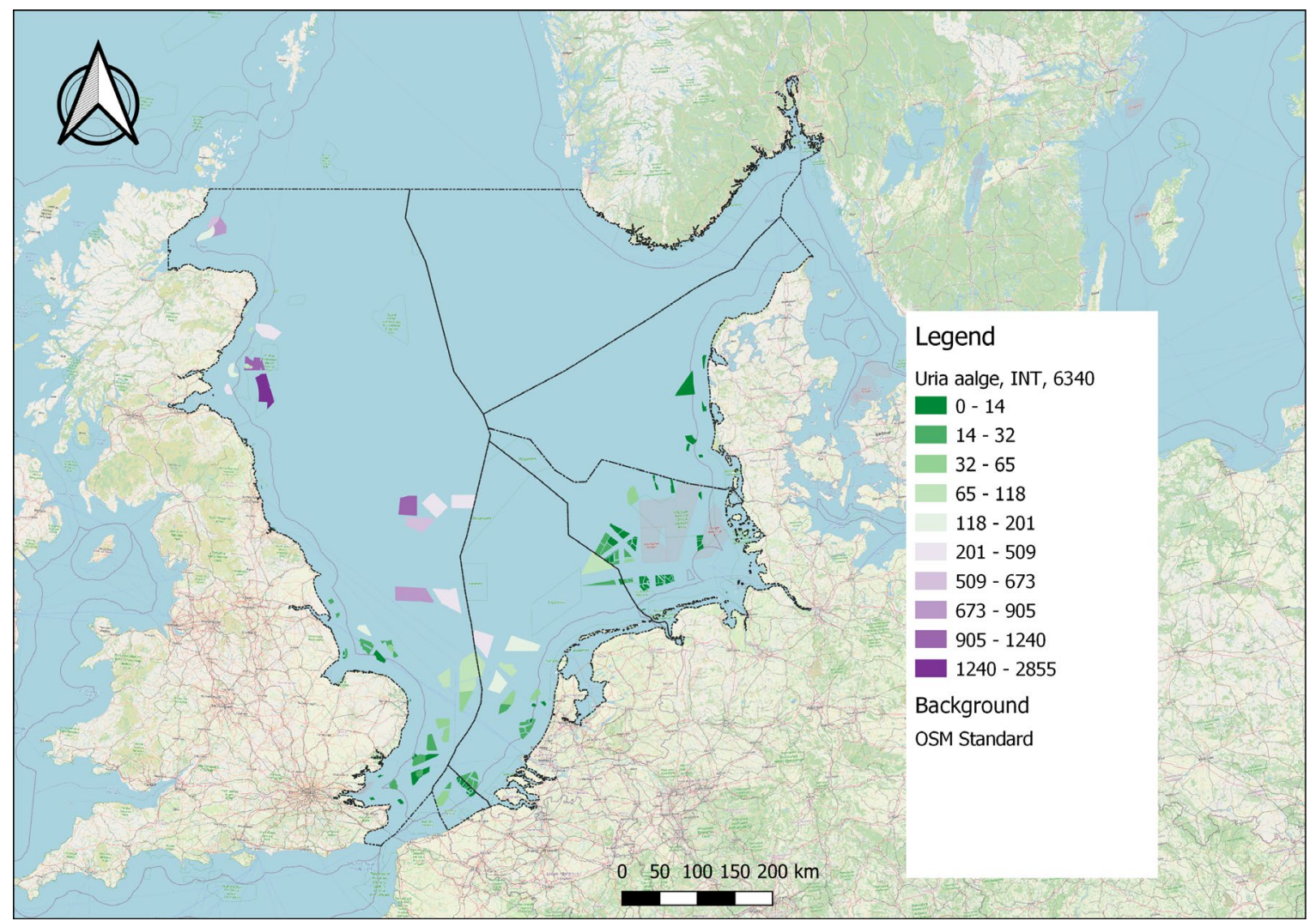

Figure 28. Common guillemot (Uria aalge, EUring 6340) total annual habitat loss casualties per OWF included in the international scenario. 
For the common guillemot, most Dutch casualties are predicted in the OWF areas far from the coast (Figure 27). The international map shows most casualties in OWF areas inside the UK EEZ (Figure 28). Bird density maps of each bimonthly period and of the annual averages can be found in separate documents (Electronic appendices E3 and E4; respectively E3_DensityMaps_19species_NATINT_period.pdf and E4_DensityMaps_19species_NATINT_yearly.pdf).

The estimated mean number of common guillemot casualties per bimonthly period for the national scenarios varies between 99 and 237 and is highest for the 'Rekenvariant III' scenario (Table 25). Using a maximum estimated abundance of 227,587 individuals this corresponds to an additional annual mortality of $0.2 \%-0.6 \%$ (Table 25 ). For the international scenario there are on average 2359 casualties per bimonthly period, corresponding to an additional annual mortality of $0.8 \%$. The number of casualties per bimonthly period for the common guillemot are shown for each Dutch OWF area in Annex Table 38. 


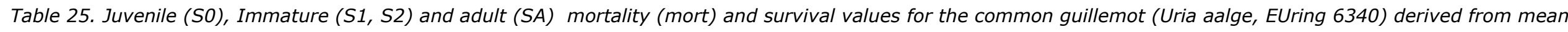
numbers of casualties per bimonthly period and max abundance

\begin{tabular}{|c|c|c|c|c|c|c|c|c|c|c|c|}
\hline Scenario & $\begin{array}{l}\text { Mean } \\
\text { casualties }\end{array}$ & $\begin{array}{c}\text { Max } \\
\text { abundance }\end{array}$ & Mort & Mort So & Mort S1 & Mort S2 & Mort SA & Survival so & Survival Si & Survival S2 & Survival SA \\
\hline Null & & & & & & & & 0.60800 & 0.77400 & 0.85800 & 0.94900 \\
\hline Basic 2030 & 99 & 227587 & 0.00258 & 0.00258 & 0.00258 & 0.00258 & 0.00258 & 0.60542 & 0.77142 & 0.85542 & 0.94642 \\
\hline Rekenvariant II & 186 & 227587 & 0.00488 & 0.00488 & 0.00488 & 0.00488 & 0.00488 & 0.60312 & 0.76912 & 0.85312 & 0.94412 \\
\hline Rekenvariant III & 237 & 227587 & 0.00622 & 0.00622 & 0.00622 & 0.00622 & 0.00622 & 0.60178 & 0.76778 & 0.85178 & 0.94278 \\
\hline Rekenvariant I & 171 & 227587 & 0.00448 & 0.00448 & 0.00448 & 0.00448 & 0.00448 & 0.60352 & 0.76952 & 0.85352 & 0.94452 \\
\hline International & 2359 & 1677205 & 0.00841 & 0.00841 & 0.00841 & 0.00841 & 0.00841 & 0.59959 & 0.76559 & 0.84959 & 0.94059 \\
\hline
\end{tabular}




\subsubsection{Common guillemot population-level effects}

The estimated additional mortality from habitat loss due to OWFs does not lead to a violation of the ALI set for the common guillemot. Median population growth rates estimated for the national scenarios range between 1.036 and 1.041 (Table 26). Population growth rates estimated for all scenarios are slightly different from the null scenario (Figure 29). The probability that a violation of the population abundance threshold results from an OWF-induced impact ranges between $6.6 \%$ to $15 \%$ for the national scenarios and equals $18.9 \%$ for the international scenario (Table 26 ).

Table 26. Population growth rates and ALI statistics for the common guillemot (Uria aalge, EUring 6340). Median and 5\% and 95\% quantiles of the population growth rate ('Lambda') distribution are reported. ' $P$ impact' represents the fraction of the distribution of Lambda that is below the threshold of a $30 \%$ smaller population abundance compared to the median lambda of the null scenario after 3 generations, which occurs for a Lambda of 1.038. ' $P$ causality' is the probability that the violation of the population abundance threshold results from the OWF impact. 'ALI $0.5^{\prime}$ shows whether $P$ causality exceeds 0.5 , the ALI threshold (see Table 8).

\begin{tabular}{ccccccc} 
Scenario & Lambda & Lambda & Lambda & P impact & P causallity & ALI 0.5 \\
median & q05 & q95 & & \\
\hline Basic 2030 & 1.044 & 0.948 & 1.099 & 0.4405 & \\
\hline Rekenvariant II & 1.041 & 0.945 & 1.096 & 0.4716 & 0.066 & FALSE \\
\hline Rekenvariant III & 1.037 & 0.942 & 1.094 & 0.5019 & 0.122 & FALSE \\
\hline Rekenvariant I & 1.036 & 0.942 & 1.092 & 0.5184 & 0.150 & FALSE \\
\hline International & 1.033 & 0.939 & 1.090 & 0.5428 & 0.189 & FALSE \\
\hline
\end{tabular}

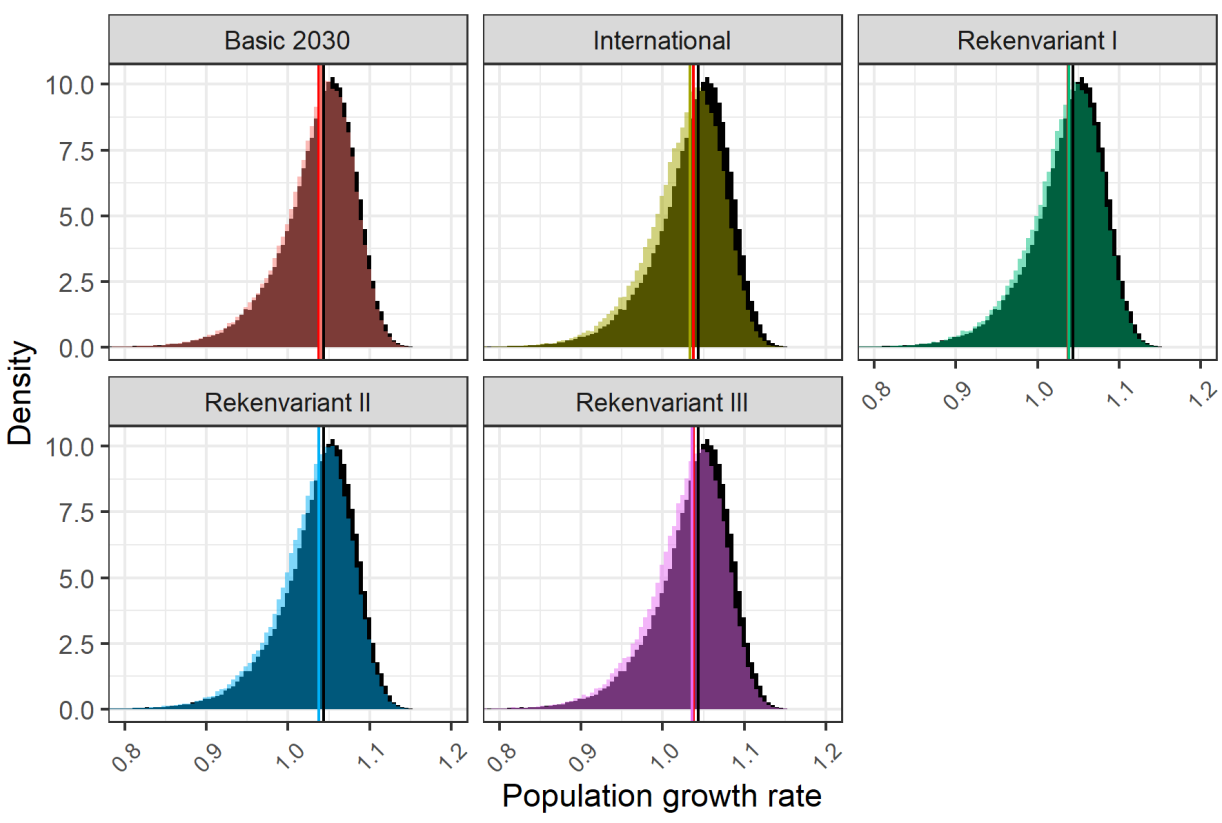

Figure 29. Distribution of population growth rates of the common guillemot (Uria aalge, EUring 6340) for the different scenarios. Vertical lines indicate the median population growth rates of the ALI threshold (red), the null scenario (black) and each scenario(colours). The distributions for each scenario (in colours) overlay the distribution of the null scenario (in black). 


\subsection{Razorbill (Alca torda)}

\subsubsection{Razorbill habitat loss casualties and mortality}

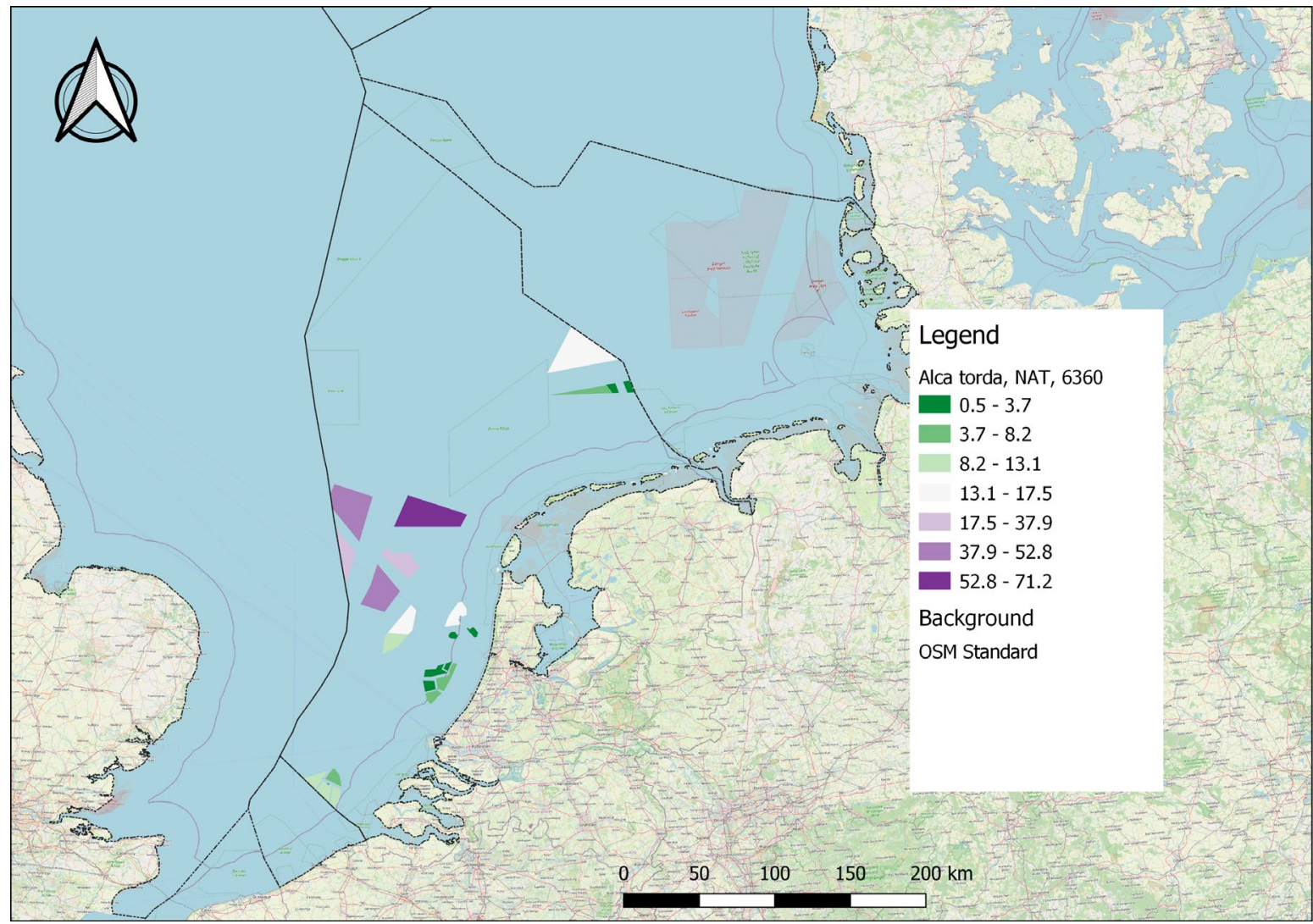

Figure 30. Razorbill (Alca torda, EUring 6360) total annual habitat loss casualties per OWF included in the national scenarios.

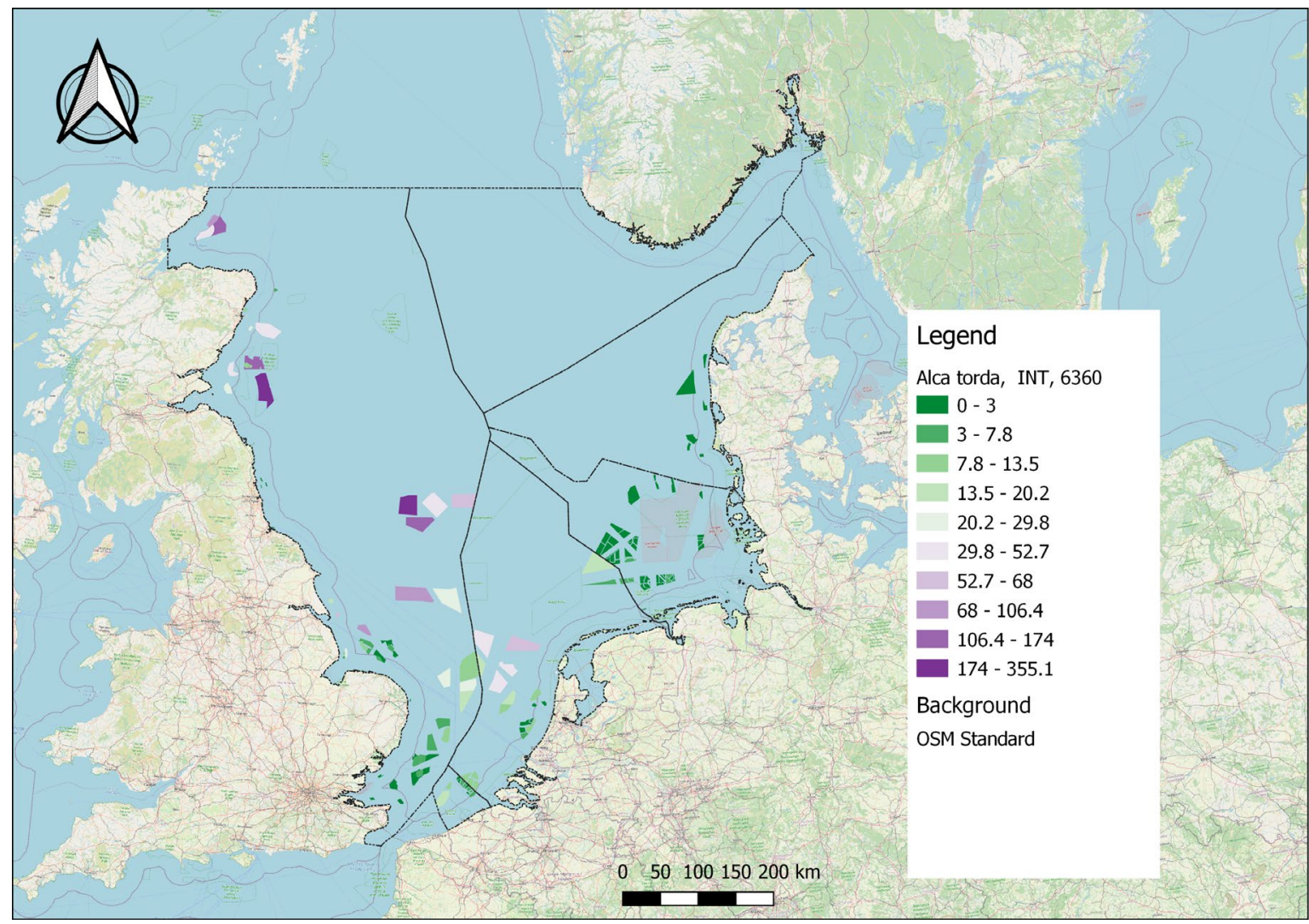

Figure 31. Razorbill (Alca torda, EUring 6360) total annual habitat loss casualties per OWF included in of the international scenario. 
For the razorbill, most Dutch casualties are predicted in the OWF areas far from the coast (Figure 30). The international map shows most casualties in OWF areas inside the UK EEZ but inside the Dutch OWF areas in the central North Sea medium to high numbers of razorbill casualties are also predicted (Figure 31). Bird density maps of each bimonthly period and of the annual averages can be found in separate documents (Electronic appendices E3 and E4; respectively

E3_DensityMaps_19species_NATINT_period.pdf and E4_DensityMaps_19species_NATINT_yearly.pdf).

The estimated mean number of razorbill casualties per bimonthly period for the national scenarios varies between 28 and 62 and is highest for the 'Rekenvariant III' scenario (Table 27). Using a maximum estimated abundance of 61,669 individuals this corresponds to an additional annual mortality of $0.2 \%-0.6 \%$ (Table 27 ). For the international scenario there are on average 435 casualties per two month period, on an estimated maximum abundance of 227,439 individuals. This corresponds to an additional annual mortality of $1.1 \%$. The number of casualties per bimonthly period for the razorbill are shown for each Dutch OWF area in Annex Table 38.

Table 27. Immature (S01) and adult (SA) mortality (mort) and survival values for the razorbill (Alca torda, EUring 6360) derived from mean numbers of casualties per bimonthly period and max abundance

\begin{tabular}{|c|c|c|c|c|c|c|c|}
\hline Scenario & $\begin{array}{c}\text { Mean } \\
\text { casualtie } \\
\mathrm{s}\end{array}$ & $\begin{array}{c}\text { Max } \\
\text { abundanc } \\
e\end{array}$ & Mort & Mort SO1 & Mort SA & $\begin{array}{l}\text { Survival } \\
\text { S01 }\end{array}$ & $\begin{array}{c}\text { Surviva } \\
\text { SA }\end{array}$ \\
\hline Null & & & & & & 0.64300 & 0.90900 \\
\hline Basic 2030 & 28 & 61669 & 0.00267 & 0.00267 & 0.00267 & 0.64033 & 0.90633 \\
\hline Rekenvariant II & 55 & 61669 & 0.00524 & 0.00524 & 0.00524 & 0.63776 & 0.90376 \\
\hline Rekenvariant III & 62 & 61669 & 0.00602 & 0.00602 & 0.00602 & 0.63698 & 0.90298 \\
\hline Rekenvariant I & 51 & 61669 & 0.00487 & 0.00487 & 0.00487 & 0.63813 & 0.90413 \\
\hline International & 435 & 227439 & 0.01142 & 0.01142 & 0.01142 & 0.63158 & 0.89758 \\
\hline
\end{tabular}

\subsubsection{Razorbill population level effects}

The estimated additional mortality from habitat loss due to OWFs does not lead to a violation of the ALI set for the razorbill. Median population growth rates estimated for the national scenarios range between 0.999 and 1.003 (Table 28) and equals 0.992 for the international scenario. The probability that a violation of the population abundance threshold results from an OWF-induced impact ranges between $4 \%-9 \%$ for the national scenarios and equals $16.3 \%$ for the international scenario (Table 28). Population growth rates estimated for all scenarios are slightly different from the null scenario (Figure 32).

Table 28: Population growth rates and ALI statistics for the razorbill (Alca torda, EUring 6360). Median and $5 \%$ and $95 \%$ quantiles of the population growth rate ('Lambda') distribution are reported. ' $P$ impact' represents the fraction of the distribution of Lambda that is below the threshold of a $30 \%$ smaller population abundance compared to the median lambda of the null scenario after 3 generations, which occurs for a Lambda of 0.998. ' $P$ causality' is the probability that the violation of the population abundance threshold results from the OWF impact. 'ALI $0.5^{\prime}$ shows whether $P$ causality exceeds 0.5 , the ALI threshold (see Table 8).

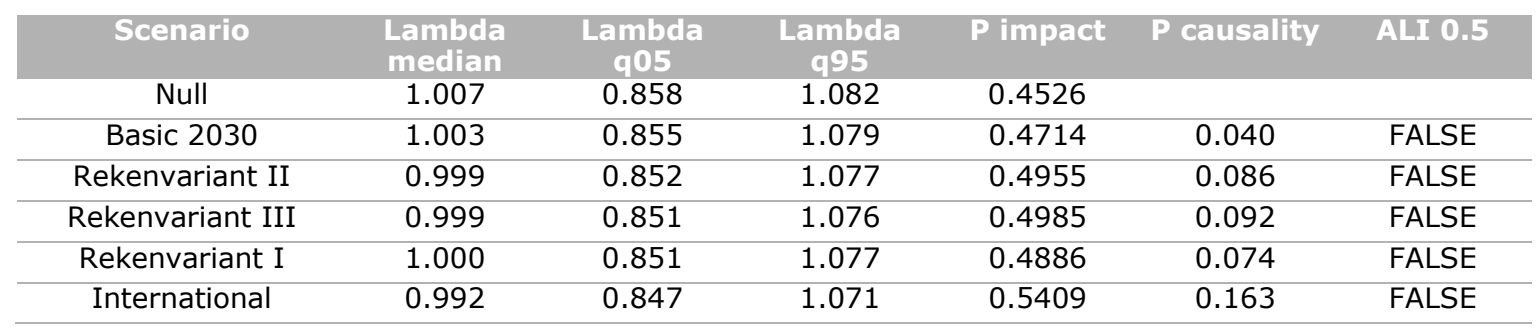




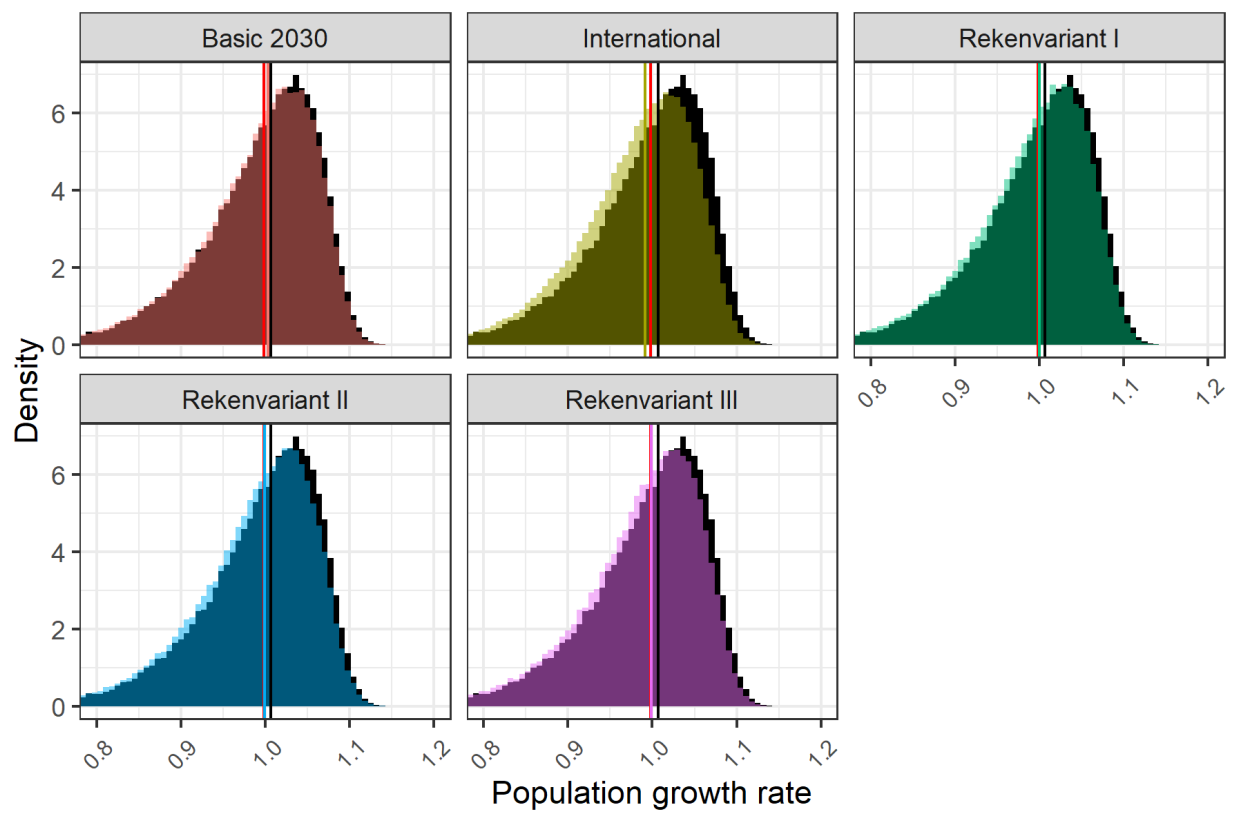

Figure 32. Distribution of population growth rates of the razorbill (Alca torda, EUring 6360) for the different scenarios. Vertical lines indicate the median population growth rates of the ALI threshold (red), the null scenario (black) and each scenario(colours). The distributions for each scenario (in colours) overlay the distribution of the null scenario (in black).

\subsection{Atlantic puffin (Fratercula arctica)}

\subsubsection{Atlantic puffin habitat loss casualties and mortality}

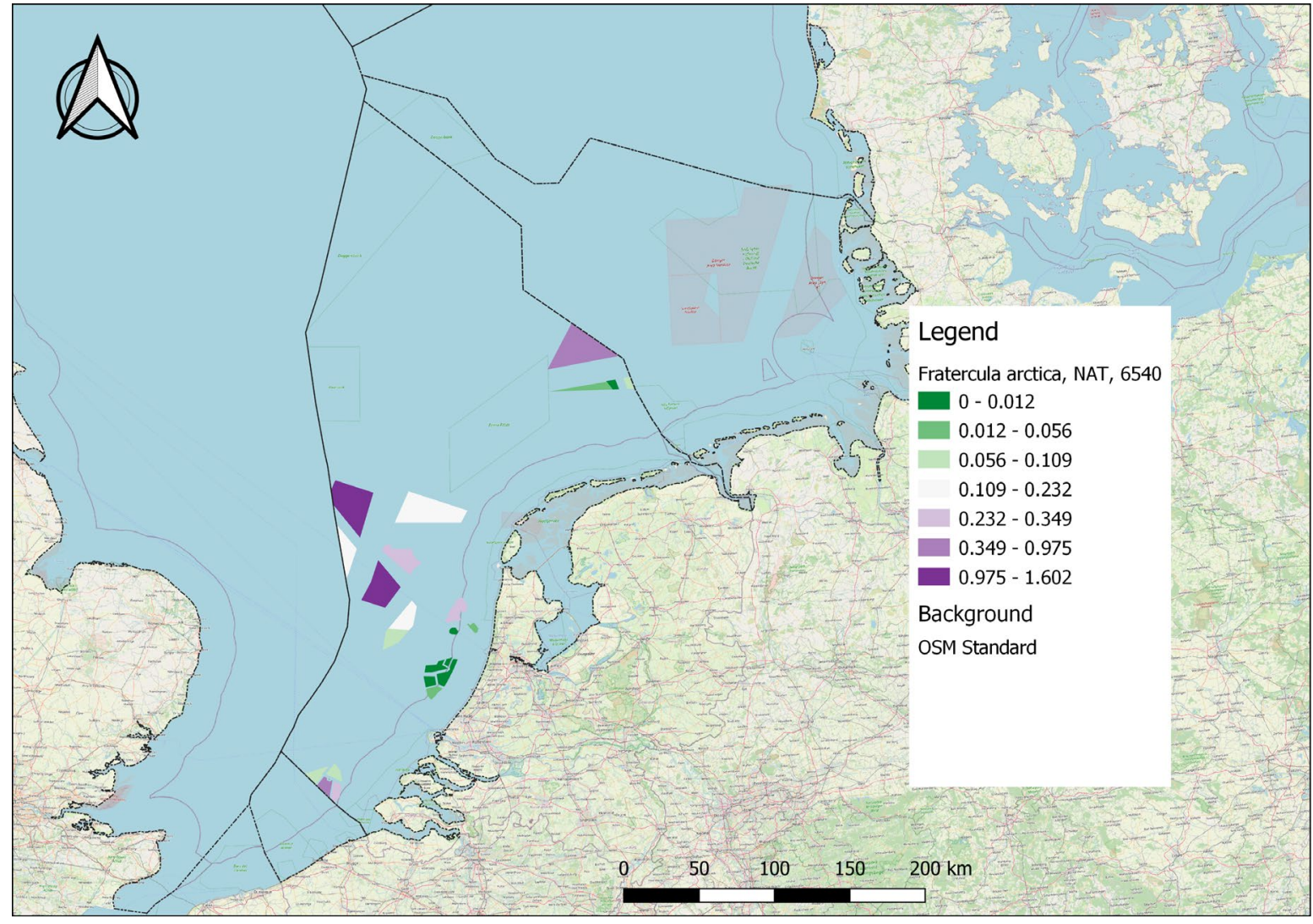

Figure 33. Atlantic puffin (Fratercula arctica, EUring 6540) total annual habitat loss casualties per OWF included in the national scenarios. 


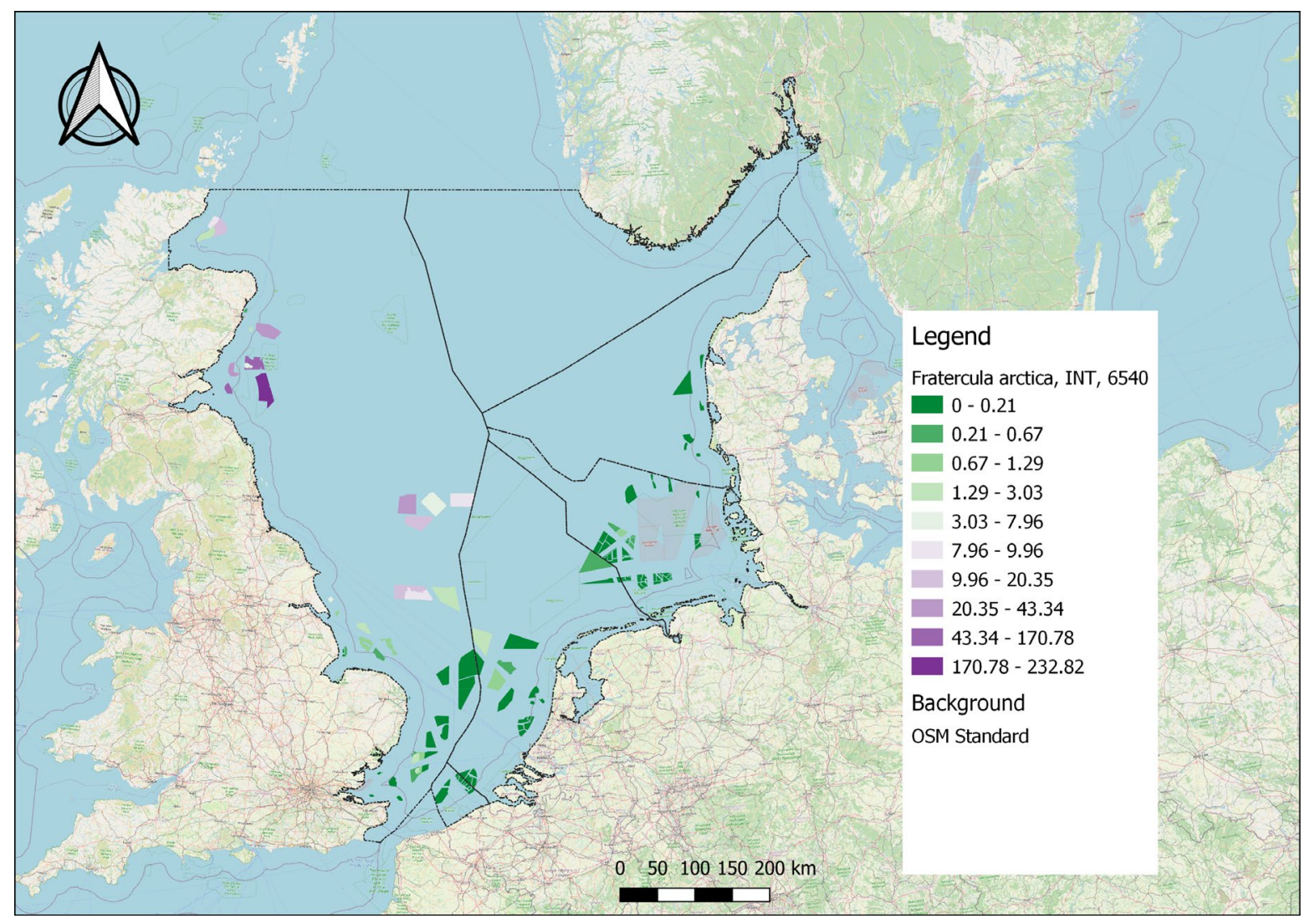

Figure 34. Atlantic puffin (Fratercula arctica, EUring 6540) total annual habitat loss casualties per OWF included in the international scenario.

For the Atlantic puffin, most Dutch casualties are predicted in the areas further away from the coast (Figure 33). The international map predicts few casualties in Dutch OWF areas and most in the OWF areas along the Scottish coast (Figure 34). Bird density maps of each bimonthly period and of the annual averages can be found in separate documents (Electronic appendices E3 and E4; respectively E3_DensityMaps_19species_NATINT_period.pdf and E4_DensityMaps_19species_NATINT_yearly.pdf).

The estimated mean number of Atlantic puffin casualties per bimonthly period for the national scenarios varies between 1 and 2 and is highest for the 'Rekenvariant III' scenario (Table 29). Using a maximum estimated abundance of 2,215 individuals this corresponds to an additional annual mortality between $0.14 \%-0.29 \%$ (Table 29 ). For the international scenario there are on average 118 casualties per two month period, on an estimated maximum abundance of 231,775 individuals. This corresponds to an additional annual mortality of $0.3 \%$. The number of casualties per bimonthly period for the Atlantic puffin are shown for each Dutch OWF area in Annex Table 38. 


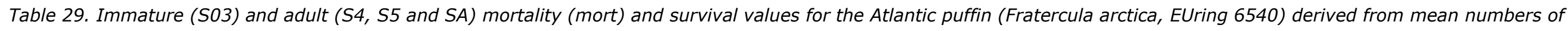
casualties per bimonthly period and max abundance.

\begin{tabular}{|c|c|c|c|c|c|c|c|c|c|c|c|}
\hline Scenario & $\begin{array}{l}\text { Mean } \\
\text { casualties }\end{array}$ & $\begin{array}{c}\text { Max } \\
\text { abundance }\end{array}$ & Mort & Mort So3 & Mort S4 & Mort S5 & mort SA & Survival $\mathrm{SO}_{3}$ & Survival 54 & Survival S5 & Survival SA \\
\hline null & & & & & & & & 0.71000 & 0.78000 & 0.80000 & 0.93000 \\
\hline Basic 2030 & 1 & 2215 & 0.00144 & 0.00144 & 0.00144 & 0.00144 & 0.00144 & 0.70856 & 0.77856 & 0.79856 & 0.92856 \\
\hline Rekenvariant II & 1 & 2215 & 0.00228 & 0.00228 & 0.00228 & 0.00228 & 0.00228 & 0.70772 & 0.77772 & 0.79772 & 0.92772 \\
\hline Rekenvariant III & 2 & 2215 & 0.00299 & 0.00299 & 0.00299 & 0.00299 & 0.00299 & 0.70701 & 0.77701 & 0.79701 & 0.92701 \\
\hline Rekenvariant I & 1 & 2215 & 0.00217 & 0.00217 & 0.00217 & 0.00217 & 0.00217 & 0.70783 & 0.77783 & 0.79783 & 0.92783 \\
\hline International & 118 & 231775 & 0.00305 & 0.00305 & 0.00305 & 0.00305 & 0.00305 & 0.70695 & 0.77695 & 0.79695 & 0.92695 \\
\hline
\end{tabular}




\subsubsection{Atlantic puffin population level effects}

The estimated additional mortality from habitat loss due to OWFs does not lead to a violation of the ALI set for the Atlantic puffin. Median population growth rates estimated for the national scenarios range between 0.998 and 1.000 (Table 30) and equals 0.998 for the international scenario. The probability that a violation of the population abundance threshold results from an OWF-induced impact ranges between $2.9 \%-6.2 \%$ for the national scenarios and equals $6.1 \%$ for the international scenario (Table 30). Population growth rates estimated for all scenarios are similar to the null scenario (Figure 35).

Table 30. Population growth rate and ALI statistics for the Atlantic puffin (Fratercula arctica, EUring 6540). Median and 5\% and 95\% quantiles of the population growth rate ('Lambda') distribution are reported. ' $P$ impact' represents the fraction of the distribution of Lambda that is below the threshold of a $15 \%$ smaller population abundance compared to the median lambda of the null scenario after 3 generations, which occurs for a Lambda of 0.998. ' $P$ causality' is the probability that the violation of the population abundance threshold results from the OWF impact. 'ALI 0.1 ' shows whether $P$ causality exceeds 0.1 , the ALI threshold (see Table 8).

\begin{tabular}{|c|c|c|c|c|c|c|}
\hline scenario & $\begin{array}{l}\text { Lambda } \\
\text { median }\end{array}$ & $\begin{array}{l}\text { Lambda } \\
\text { q05 }\end{array}$ & $\begin{array}{l}\text { Lambda } \\
\text { q95 }\end{array}$ & P impact & P causality & ALT 0.1 \\
\hline Basic 2030 & 1.000 & 0.891 & 1.071 & 0.4900 & 0.029 & FALSE \\
\hline Rekenvariant III & 0.998 & 0.889 & 1.069 & 0.5072 & 0.062 & FALSE \\
\hline Rekenvariant I & 0.999 & 0.889 & 1.070 & 0.4951 & 0.039 & FALSE \\
\hline International & 0.998 & 0.888 & 1.069 & 0.5068 & 0.061 & FALSE \\
\hline
\end{tabular}
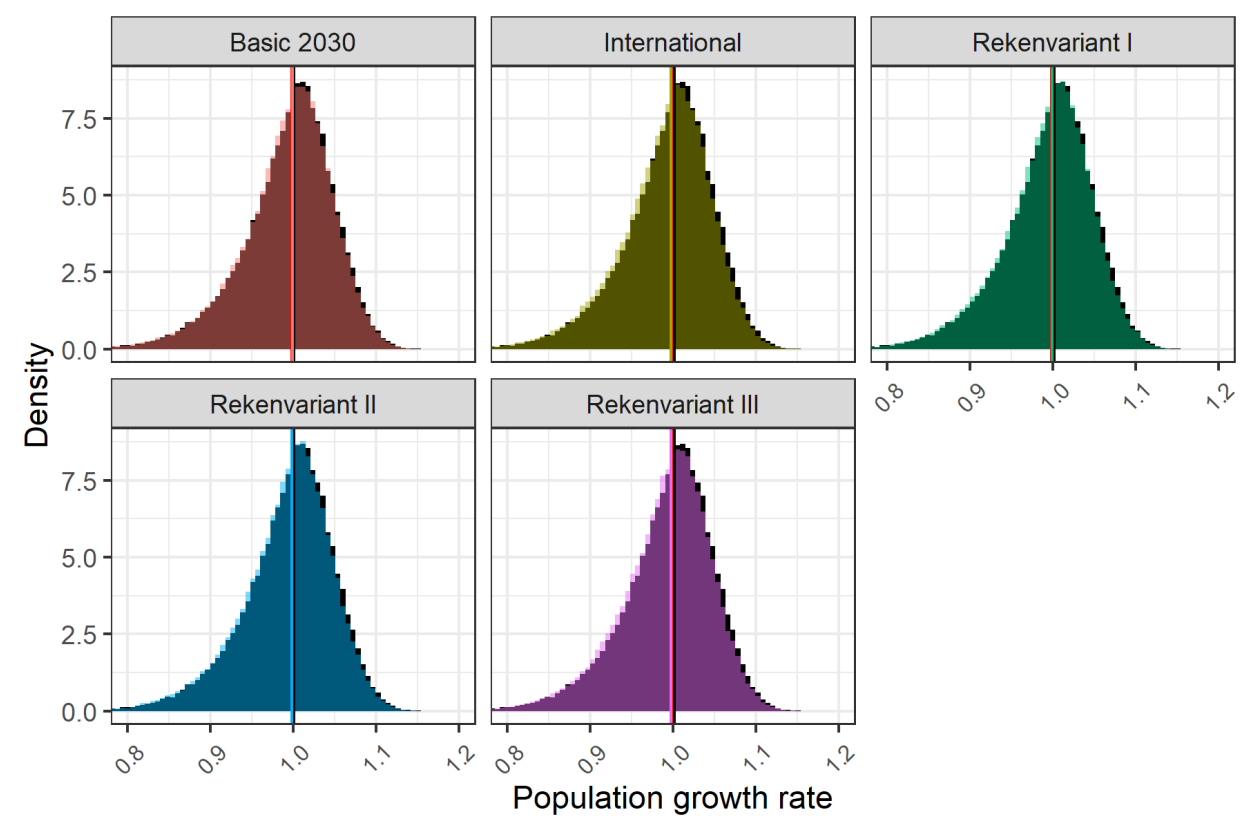

Figure 35. Distribution of population growth rates of the Atlantic puffin (Fratercula arctica, EUring 6540) for the different scenarios. Vertical lines indicate the median population growth rates of the ALI threshold (red), the null scenario (black) and each scenario(colours). The distributions for each scenario (in colours) overlay the distribution of the null scenario (in black). 


\section{Quality Assurance}

Wageningen Marine Research utilises an ISO 9001:2015 certified quality management system. This certificate is valid until 15 December 2021. The organisation has been certified since 27 February 2001. The certification was issued by DNV GL. 


\section{References}

Ashcroft, R. E. 1979. Survival Rates and Breeding Biology of Puffins on Skomer Island, Wales. Ornis Scandinavica 10:100.

Baptist, H. J. M., and P. A. Wolf. 1993. Atlas van de vogels van het Nederlands Continentaal Plat. Page Rapport DGW-93.013, Rijkswaterstaat, Dienst Getijdewateren, Middelburg.

Beijersbergen, R. 2001. Grote Sterns op de Hooge Platen. De levende natuur 102:98-99.

Booth, C. J. 1999. Breeding success of Red-throated Divers on Orkney Mainland, 1973-1998. Scottish Birds 20:94-97.

Breton, A. R., A. W. Diamond, and S. W. Kress. 2006. Encounter, survival, and movement probabilities from an Atlantic Puffin (Fratercula arctica) metapopulation. Ecological Monographs 76:133-149.

Buckland, S. T. ., and B. J. . Turnock. 1992. A Robust Line Transect Method. Biometrics 48:901-909.

Camphuysen, C. J., A. D. Fox, M. F. Leopold, and I. Krag Petersen. 2004. Towards standardised seabirds at sea census techniques in connection with environmental impact assessments for offshore wind farms in the U.K. Environmental Research Institute. Page COWRIE - BAM- 022002.

Crouse, D. T., L. B. Crowder, and H. Caswell. 1987. A Stage-Based Population Model for Loggerhead Sea Turtles and Implications for Conservation. Ecology 68:1412-1423.

Deakin, Z., K. Hamer, R. Sherley, S. Bearhop, T. Bodey, B. Clark, W. Grecian, M. Gummery, J. Lane, G. Morgan, L. Morgan, R. Phillips, E. Wakefield, and S. Votier. 2019. Sex differences in migration and demography of a wide-ranging seabird, the northern gannet. Marine Ecology Progress Series 622:191-201.

Derks, P., and K. De Kraker. 2005. De ontwikkeling van de kolonie grote sterns in het Grevelingenmeer in vergelijking met de rest van Nederland, België en aangrenzend NoordFrankrijk. Nieuwsbrief Nederlandse Zeevogelgroep 6:2-4.

Dierschke, V., R. W. Furness, and S. Garthe. 2016. Seabirds and offshore wind farms in European waters: Avoidance and attraction. Biological Conservation 202:59-68.

Drewitt, A. L., and R. H. W. Langston. 2006. Assessing the impacts of wind farms on birds: Impacts of wind farms on birds. Ibis 148:29-42. 
Eklöf, K., and P. Koskimies. 2018. Kaakkurien kanssa 42 vuotta - Miten kaakkurit liikkuvat ja kuinka pesinnät onnistuvat? Linnut-vuosikirja 2017:118-121.

Eriksson, M. O. G. 2012. Projekt Lom 2011. Vår Fågelvärld Supplement 52:45-55.

Fayet, A. L., R. Freeman, T. Anker-Nilssen, A. Diamond, K. E. Erikstad, D. Fifield, M. G. Fitzsimmons, E. S. Hansen, M. P. Harris, M. Jessopp, A.-L. Kouwenberg, S. Kress, S. Mowat, C. M. Perrins, A. Petersen, I. K. Petersen, T. K. Reiertsen, G. J. Robertson, P. Shannon, I. A. Sigurðsson, A. Shoji, S. Wanless, and T. Guilford. 2017. Ocean-wide Drivers of Migration Strategies and Their Influence on Population Breeding Performance in a Declining Seabird. Current Biology 27:3871-3878.e3.

Fijn, R. C., R. S. A. van Bemmelen, J. W. de Jong, F. A. Arts, D. Beuker, E. L. Bravo Rebolledo, B. W. R. Engels, M. Hoekstein, R.-J. Jonkvorst, S. Lilipaly, M. Sluijter, K. D. Van Straalen, and P. A. Wolf. 2019. Verspreiding en abundantie van zeevogels en zeezoogdieren op het Nederlands Continentaal Plat in 2018-2019. Page RWS-Centrale Informatievoorziening BM 19.23. Bureau Waardenburg Rapportnr. 19-258. Bureau Waardenburg \& Deltamilieu Projecten, Culemborg.

Fijn, R. C., R. S. A. van Bemmelen, J. W. de Jong, F. A. Arts, D. Beuker, E. L. Bravo Rebolledo, B. W. R. Engels, M. Hoekstein, R.-J. Jonkvorst, S. Lilipaly, M. Sluijter, K. D. Van Straalen, and P. A. Wolf. 2020. Verspreiding en abundantie van zeevogels en zeezoogdieren op het Nederlands Continentaal Plat in 2019-2020. Page RWS-Centrale Informatievoorziening BM 20.22. Bureau Waardenburg Rapportnr. 20-324. Bureau Waardenburg \& Deltamilieu Projecten, Culemborg. Gomersall, C. H. 1986. Breeding performance of the red-throated diver Gavia stellata in Shetland. Ecography 9:277-284.

Grosbois, V., and P. M. Thompson. 2005. North Atlantic climate variation influences survival in adult fulmars. Oikos 109:273-290.

Harris, M. P., T. Anker-Nilssen, R. H. McCleery, K. E. Erikstad, D. N. Shaw, and V. Grosbois. 2005. Effect of wintering area and climate on the survival of adult Atlantic puffins Fratercula arctica in the eastern Atlantic. Mar Ecol Prog Ser 297:283-296.

Harris, M. P., F. Daunt, M. I. Bogdanova, J. J. Lahoz-Monfort, M. A. Newell, R. A. Phillips, and S. Wanless. 2013. Inter-year differences in survival of Atlantic puffins Fratercula arctica are not associated with winter distribution. Marine Biology 160:2877-2889. 
Harris, M. P., M. Frederiksen, and S. Wanless. 2007. Within- and between-year variation in the juvenile survival of Common Guillemots Uria aalge: Survival of juvenile Guillemots. Ibis $149: 472-481$

Harris, M. P., M. Heubeck, M. I. Bogdanova, M. A. Newell, S. Wanless, and F. Daunt. 2020. The importance of observer effort on the accuracy of breeding success estimates in the Common Guillemot Uria aalge. Bird Study 67:93-103.

Harris, M. P., and S. Wanless. 1989. The breeding biology of Razorbills Alca torda on the Isle of May. Bird Study 36:105-114.

Harris, M. P., and S. Wanless. 2011. The Puffin. T. \& A.D. Poyser, London.

Hemmingsson, E., and M. O. G. Eriksson. 2002. Ringing of Red-throated Diver Gavia stellata Blackthroated Diver Gavia arctica in Sweden. Wetlands International Diver/Loon Specialist Group Newsletter 4:8-13.

Hin, V. 2021. KEC4popmodels: Matrix population models to assess mortality effects of Offshore Wind Parks on seabird Populations. Wageningen Marine Research.

Horswill, C., and R. A. Robinson. 2015. Review of Seabird Demographic Rates and Density Dependence. Page 126. Peterborough.

Jenouvrier, S., C. Barbraud, and H. Weimerskirch. 2003. Effects of climate variability on the temporal population dynamics of southern fulmars: Climate variability and fulmar population dynamics. Journal of Animal Ecology 72:576-587.

van der Jeugd, H., B. J. Ens, M. Versluijs, and H. Schekkerman. 2014. Geïntegreerde monitoring van vogels van de Nederlandse waddenzee. Sovon Vogelonderzoek Nederland, Nijmegen.

Kahle, D., and H. Wickham. 2013. ggmap: Spatial Visualization with ggplot2. The R Journal 5:144161.

Koffijberg, K., J. S. M. Cremer, P. De Boer, J. Nienhuis, H. Schekkerman, and J. Postma. 2017. Broedsucces van kustbroedvogels in de Waddenzee. Resultaten 2015-2016 en trends in broedsucces in 2005-2016. Wageningen / Nijmegen.

van Kooten, T., F. Soudijn, I. Tulp, C. Chen, D. Benden, and M. Leopold. 2019. The consequences of seabird habitat loss from offshore wind turbines, version 2 : Displacement and population level effects in 5 selected species. Wageningen Marine Research, IJmuiden. 
Lane, J. V., R. Jeavons, Z. Deakin, R. B. Sherley, C. J. Pollock, R. J. Wanless, and K. C. Hamer. 2020. Vulnerability of northern gannets to offshore wind farms; seasonal and sex-specific collision risk and demographic consequences. Marine Environmental Research 162:105196.

Lavers, J. L., I. L. Jones, A. W. Diamond, and G. J. Robertson. 2008. Annual survival of North American Razorbills (Alca torda) varies with ocean climate indices. Canadian Journal of Zoology 86:51-61.

Leopold, M. F., M. Boonman, M. P. Collier, N. Davaasuren, R. C. Fijn, A. Gyimesi, J. de Jong, R. H. Jongbloed, B. Jonge Poerink, J. C. Kleyheeg-Hartman, K. L. Krijgsveld, S. Lagerveld, R. Lensink, M. J. M. Poot, van der W. J.T, and M. Scholl. 2014. A first approach to deal with cumulative effects on birds and bats of offshore wind farms and other human activities in the Southern North Sea. IMARES Report C166/14, IMARES.

Lewis, S., D. A. Elston, F. Daunt, B. Cheney, and P. M. Thompson. 2009. Effects of extrinsic and intrinsic factors on breeding success in a long lived seabird. Oikos 118:521-528.

Lloyd, C. 1974. Movement and Survival of British Razorbills. Bird Study 21:102-116.

Lloyd, C. S., and C. M. Perrins. 1977. Survival and age at first breeding in the Razorbill (Alca torda). Bird-banding 48:239-252.

Lowther, P. E., A. W. Diamond, S. W. Kress, G. J. Robertson, K. Russell, D. N. Nettleship, G. M. Kirwan, D. Christie, C. Sharpe, E. Garcia, and P. F. D. Boesman. 2020. Atlantic Puffin (Fratercula arctica). Page in S. M. Billerman, B. K. Keeney, P. G. Rodewald, and T. S. Schulenberg, editors. Birds of the World. Cornell Lab of Ornithology.

Masden, E. A., D. T. Haydon, A. D. Fox, and R. W. Furness. 2010. Barriers to movement: Modelling energetic costs of avoiding marine wind farms amongst breeding seabirds. Marine Pollution Bulletin 60:1085-1091.

Mavor, R. A., M. Heubeck, S. Schmitt, and M. Parsons. 2008. Seabird numbers and breeding success in Britain and Ireland, 2006. Page 113. Joint Nature Conservation Committe, Peterborough.

Meade, J., B. J. Hatchwell, J. L. Blanchard, and T. R. Birkhead. 2013. The population increase of common guillemots Uria aalge on Skomer Island is explained by intrinsic demographic properties. Journal of Avian Biology 44:055-061.

Newell, M., M. P. Harris, C. M. Gunn, S. Burthe, S. Wanless, and F. Daunt. 2016. Isle of May seabird studies in 2015. Page 24. Joint Nature Conservation Committe, Peterborough. 
Newell, M., M. P. Harris, A. Skene, S. Wanless, and F. Daunt. 2013. Isle of May seabird studies in 2010. Page 29. Joint Nature Conservation Committe, Aberdeen.

O’Brien, S. H., A. S. C. P. Cook, and R. A. Robinson. 2017. Implicit assumptions underlying simple harvest models of marine bird populations can mislead environmental management decisions. Journal of Environmental Management 201:163-171.

Ollason, J. C., and G. M. Dunnet. 1978. Age, Experience and Other Factors Affecting the Breeding Success of the Fulmar, Fulmarus glacialis, in Orkney. The Journal of Animal Ecology 47:961.

Potiek, A., M. P. Collier, H. Schekkerman, and R. C. Fijn. 2019. Effects of turbine collision mortality on population dynamics of 13 bird species. Page 252. Bureau Waardenburg Report 18-342, Bureau Waardenburg, Culemborg.

Potiek, A., G. IJntema, T. van Kooten, M. F. Leopold, and M. P. Collier. 2021a. Acceptable Levels of Impact from offshore wind farms on the Dutch Continental Shelf for 21 bird species. A novel approach for defining acceptable levels of additional mortality from turbine collisions and avoidance-induced habitat loss. Bureau Waardenburg Report 21-0120, Bureau Waardenburg, Culemborg, The Netherlands.

Potiek, A., J. J. Leemans, R. P. Middelveld, and A. Gyimesi. 2021b. Cumulative impact assessment of collisions with existing and planned offshore wind turbines in the southern North Sea. Analysis of additional mortality using collision rate modelling and impact assessment based on population modelling for development according to roadmap 2030 and 2040. Rapportnr. 21205, Bureau Waardenburg, Culemborg.

Reed, T. E., M. P. Harris, and S. Wanless. 2015. Skipped breeding in common guillemots in a changing climate: restraint or constraint? Frontiers in Ecology and Evolution 3.

Reynolds, T. J., M. P. Harris, R. King, R. L. Swann, D. C. Jardine, M. Frederiksen, and S. Wanless. 2011. Among-colony synchrony in the survival of Common Guillemots Uria aalge reflects shared wintering areas: 14 .

van Roomen, M., J. Stahl, H. Schekkerman, C. van Turnhout, and R. Vogel. 2013. Advies ten behoeve van het opstellen van een monitoringplan voor vogels in het Nederlandse Noordzeegebied. Page Sovon-rapport 2013/22.

Sandvik, H., K. E. Erikstad, R. T. Barrett, and N. G. Yoccoz. 2005. The effect of climate on adult survival in five species of North Atlantic seabirds. Journal of Animal Ecology 74:817-831. 
Schekkerman, H., F. Arts, R.-J. Buijs, W. Courtens, T. Van Daele, R. Fijn, A. Van Kleunen, H. Van der Jeugd, M. Roodbergen, E. Stienen, L. De Vries, and B. J. Ens. 2021. Geïntegreerde populatieanalyse van vijf soorten kustbroedvogels in het Zuidwestelijk Deltagebied. Sovon Vogelonderzoek Nederland, Nijmegen.

Schmutz, J. A. 2014. Survival of Adult Red-Throated Loons ( Gavia stellata ) May be Linked to Marine Conditions. Waterbirds 37:118-124.

Shaw, D. 2012. Fair isle's seabirds in 2009/2010. Page Fair Isle Observatory report for 2009-10. Fair Isle Observatory, report for 2009-10, Fair Isle Bird Observatory, Fair Isle, Shetland ZE2 9JU.

Shaw, D. N., C. A. Holt, H. E. Maggs, and D. de Palacio. 2002. Fair Isle Seabird Studies 2000. Page 52. Peterborough.

St. John Glew, K., S. Wanless, M. P. Harris, F. Daunt, K. E. Erikstad, H. Strøm, J. R. Speakman, B. Kürten, and C. N. Trueman. 2019. Sympatric Atlantic puffins and razorbills show contrasting responses to adverse marine conditions during winter foraging within the North Sea. Movement Ecology 7:33.

Stienen, E., and A. Brenninkmeijer. 1992. Ecologisch profiel van de grote stern (Sterna sandvicensis). DLO Instituut voor Bos- en Natuuronderzoek, Arnhem.

Stubbings, E. M., B. I. Buche, J. A. Riordan, B. Baker, and M. J. Wood. 2018. Seabird monitoring on Skomer Island in 2018. Joint Nature Conservation Committe, Peterborough.

Tasker, M., P. Jones, T. Dixon, and B. Blake. 1984. Counting Seabirds at Sea from Ships: A Review of Methods Employed and a Suggestion for a Standardized Approach. The Auk 101:567-577.

Thompson, P. M., and J. C. Ollason. 2001. Lagged effects of ocean climate change on fulmar population dynamics. Nature 413:417-420.

Veen, J. 1977. Functional and Causal Aspects of Nest Distribution in Colonies of the Sandwich Tern (Sterna S. Sandvicencis Lath.). Behaviour. Supplement:I-201.

van der Wal, J. T., M. E. B. van Puijenbroek, and M. F. Leopold. 2018. Cumulatieve effecten van offshore wind parken: habitatverlies zeevogels: update voor vijf zeevogelsoorten tot 2030. Wageningen Marine Research rapport C059/18, Wageningen Marine Research.

Wanless, S., M. Frederiksen, M. P. Harris, and S. N. Freeman. 2006. Survival of Gannets Morus bassanus in Britain and Ireland, 1959-2002. Bird Study 53:79-85. 


\section{Justification}

Report C070/21

Project Number: 4315100166

The scientific quality of this report has been peer reviewed by a colleague scientist and a member of the Management Team of Wageningen Marine Research

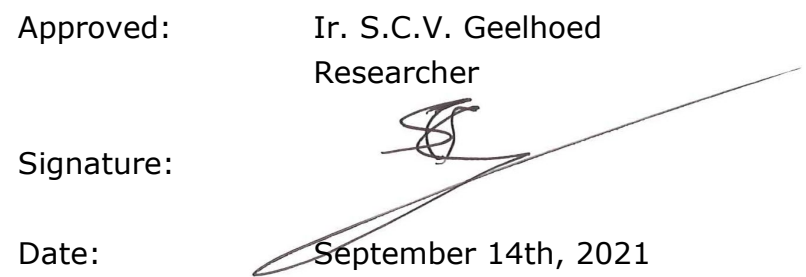

Approved: Drs. J.J. Riensema
Manager business operations
Signature: 


\section{Annex 1 Population models}

\section{Diver sp. (Gavia sp.)}

The matrix model for the diver sp. is based on the red-throated diver Gavia stellata and contains three life stages; a juvenile stage $J_{01}$ (age 0 and 1 ), a pre-breeding adult stage $A_{2}$ (age 2) and a breeding adult stage $A_{B}$ (age $3+$ ). This subdivision was based on the available data on survival, which was estimated for individuals at age 0 , age 1 and age $3+$. Because reproduction starts at age 3 (Horswill \& Robinson, 2015), we include a pre-breeding adult stage for individuals with age 2. Survival and transitions between stages during the non-breeding season are described by the winter transition matrix $\mathbf{A}_{w, G s}$

$$
\mathbf{A}_{w, G s}=\left(\begin{array}{ccc}
\frac{S_{J}\left(1-S_{J}\right)}{\left(1-S_{J}^{2}\right)} & 0 & 0 \\
\frac{S_{J}^{2}\left(1-S_{J}\right)}{\left(1-S_{J}^{2}\right)} & 0 & 0 \\
0 & S_{A} & S_{A}
\end{array}\right) .
$$

With annual survival of juveniles $S_{J}$, and survival of pre-breeding and breeding adults $S_{A}$.

A fraction of the adults produce offspring during the breeding season. Reproduction is modelled by the summer transition matrix $\mathbf{A}_{s, G s}$ :

$$
\mathbf{A}_{s, G S}=\left(\begin{array}{ccc}
1 & 0 & F_{A}\left(1-P_{F}\right) \\
0 & 1 & 0 \\
0 & 0 & 1
\end{array}\right) .
$$

Adults produce $F_{A}$ female offspring (number of fledged female chicks per female). The probability that a female skips reproduction during the breeding season equals $P_{F}$.

The annual projection matrix is calculated as $\mathbf{A}_{G s}=\mathbf{A}_{w, G s} \cdot \mathbf{A}_{s, G s}$, which results in:

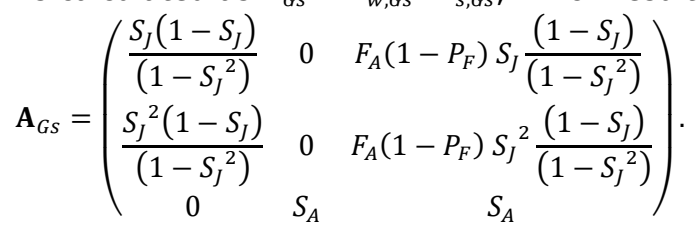

\section{Diver parameter values}

Parameter values for the diver are listed in Table 31. The value of $F_{A}$ is an average from various sources, weighted by the number of years covered and includes data from Finland (Eklöf \& Koskimies, 2018), Sweden (Eriksson, 2012) and an overall UK estimate reported by Horswill \& Robinson (2015). There is no information on the probability of skipping reproduction $\left(P_{F}\right)$ for the red-throated diver. Based on the range of estimates for other seabirds we adopt a value of 0.05 . The standard deviation for $P_{F}$ is derived from the range rule using the range $0.0-0.5$. The mean for juvenile survival $\left(S_{J}\right)$ is an average of the values for age $0(0.6)$ and age $1(0.62)$ as reported by Hemmingsson \& Eriksson (2002). The standard deviation was calculated from these two values, which probably results in an underestimate of the true variation in this parameter. Hemmingsson \& Eriksson (2002) also report a survival estimate of individuals of age 3 years and older (0.84). This value was combined with the estimate of Schmutz (2014) for adults birds in Alaska, who also reports a the standard deviation for adult survival. 
Table 31. Default parameter values for red-throated diver (Gavia stellata).

\begin{tabular}{|c|c|c|c|c|c|c|c|}
\hline Symbol & Mean & Unit & SD & Description & Remark & $\begin{array}{l}\text { Years } \\
\text { of data }\end{array}$ & Source \\
\hline$F_{A}$ & 0.381 & \# / year & 0.0905 & $\begin{array}{l}\text { fledged female } \\
\text { offspring }\end{array}$ & Data from Sweden and UK & 52 & $\begin{array}{l}1,2,3 \\
4,7\end{array}$ \\
\hline$P_{F}$ & 0.05 & - & 0.125 & $\begin{array}{l}\text { skipped breeding } \\
\text { probability }\end{array}$ & SD based on range rule & - & - \\
\hline$S_{J}$ & 0.61 & - & 0.0141 & $\begin{array}{l}\text { annual survival } \\
\text { probability age } 0-1\end{array}$ & $\begin{array}{l}\text { Based on two estimates } \\
\text { from Sweden }\end{array}$ & 17 & 5 \\
\hline$S_{A}$ & 0.861 & - & 0.132 & $\begin{array}{l}\text { annual survival } \\
\text { probability adults } \\
\text { age } 2+\end{array}$ & $\begin{array}{l}\text { Based on estimate from } \\
\text { Sweden (5) and Alaska } \\
\text { (6) }\end{array}$ & 23 & 5,6 \\
\hline$a_{m}$ & 3 & years & - & \multicolumn{2}{|l|}{ age at recruitment } & & 7 \\
\hline & \multicolumn{7}{|c|}{$\begin{array}{l}{ }^{1} \text { (Eriksson, 2012) }{ }^{2} \text { (Eklöf \& Koskimies, 2018), }{ }^{3} \text { (Gomersall, 1986), }{ }^{4} \text { (Booth, 1999), }{ }^{5} \text { (Hemmingsson \& } \\
\text { Eriksson, 2002), }{ }^{6}\left(\text { Schmutz, 2014) },{ }^{7} \text { (Horswill \& Robinson, 2015) }\right.\end{array}$} \\
\hline
\end{tabular}

\section{Northern gannet (Morus bassanus)}

The matrix model for the northern gannet (Morus bassanus) is composed of a juvenile stage: $J_{0}$ (age 0 ), three immature stages: $I_{1}$ (age 1 ), $I_{2}$ (age 2) and $I_{3}$ (age 3), a pre-breeding adult stage: $A_{4}$ (age 4 ), and a breeding adult stage $A_{B}$ (age $5+$ ). The juvenile and immature stages have different survival probabilities $\left(S_{0}, S_{1}, S_{2}\right.$ and $\left.S_{3}\right)$, while the survival probability of pre-breeding adults equals that of breeding adults $\left(S_{A}\right)$. Survival and transitions between stages during the non-breeding season are described by the winter transition matrix $\mathbf{A}_{\mathbf{w}, \boldsymbol{M b}}$ :

$$
\mathbf{A}_{\mathbf{w}, \boldsymbol{M b}}:=\left(\begin{array}{cccccc}
0 & 0 & 0 & 0 & 0 & 0 \\
S_{0} & 0 & 0 & 0 & 0 & 0 \\
0 & S_{1} & 0 & 0 & 0 & 0 \\
0 & 0 & S_{2} & 0 & 0 & 0 \\
0 & 0 & 0 & S_{3} & 0 & 0 \\
0 & 0 & 0 & 0 & S_{A} & S_{A}
\end{array}\right) .
$$

Adult females produce offspring during the breeding season. Only part of the females reproduce and parameter $P_{F}$ equals the probability of not reproducing. Because maximal clutch size of northern gannets is 1 egg (Wanless et al., 2006), the breeding success parameter $F_{A}$ describes the number of fledged chicks of both sexes per female individual. Reproduction is modelled by the summer transition matrix $\mathbf{A}_{s, M b}$ :

$$
\mathbf{A}_{s, M b}:=\left(\begin{array}{cccccc}
1 & 0 & 0 & 0 & 0 & \frac{F_{A}}{2}\left(1-P_{F}\right) \\
0 & 1 & 0 & 0 & 0 & 0 \\
0 & 0 & 1 & 0 & 0 & 0 \\
0 & 0 & 0 & 1 & 0 & 0 \\
0 & 0 & 0 & 0 & 1 & 0 \\
0 & 0 & 0 & 0 & 0 & 1
\end{array}\right) .
$$

The annual projection matrix is calculated as $\mathbf{A}_{M b}=\mathbf{A}_{w, M b} \cdot \mathbf{A}_{s, M b}$

$$
\mathbf{A}_{M b}=\left(\begin{array}{cccccc}
0 & 0 & 0 & 0 & 0 & 0 \\
S_{0} & 0 & 0 & 0 & 0 & \frac{F_{A}}{2}\left(1-P_{F}\right) S_{0} \\
0 & S_{1} & 0 & 0 & 0 & 0 \\
0 & 0 & S_{2} & 0 & 0 & 0 \\
0 & 0 & 0 & S_{3} & 0 & 0 \\
0 & 0 & 0 & 0 & S_{A} & S_{A}
\end{array}\right) .
$$

The reproduction term $\left(S_{0} \frac{F_{A}}{2}\left(1-P_{F}\right)\right)$ correctly appears in the second row of $\mathbf{A}_{M b}$, because population census occurs just after the yearling individuals have turned 1 year old.

\section{Northern gannet parameter values}

There are a number of reports of life-history parameters for this species. Horswill \& Robinson (2015) report a UK-wide average for the breeding parameter $F_{A}$, which was adopted here (Table 32). Because there are no data on probability of skipping reproduction, we adopted the same value for $P_{F}$ as for the 
red-throated diver (Table 31). Annual survival probabilities for the juvenile and immature stages were taken from Wanless et al. (2006), who report values derived from colonies at Bass Rock, Hermaness, Ailsa Craig and Great Saltee (UK and Ireland). For these colonies, Wanless et al. (2006) also report a value for adult survival, which was complemented with a more recent estimate from Bass Rock (Lane et al., 2020) and an adult survival estimate from Grassholm, Wales (Deakin et al., 2019).

Table 32. Northern gannet life-history parameters

\begin{tabular}{|c|c|c|c|c|c|c|c|}
\hline Symbol & Mean & SD & Unit & Description & Remark & $\begin{array}{l}\text { Years of } \\
\text { data }\end{array}$ & Source \\
\hline$F_{A}$ & 0.7 & 0.082 & $\begin{array}{l}\text { \# / } \\
\text { year }\end{array}$ & $\begin{array}{l}\text { Fledged number of offspring } \\
\text { per female }\end{array}$ & National average UK & $>90$ & 1 \\
\hline$P_{F}$ & 0.05 & 0.125 & - & Skipped breeding probability & $\begin{array}{l}\text { SD based on range } \\
\text { rule }\end{array}$ & & \\
\hline$S_{0}$ & 0.481 & 0.0853 & - & $\begin{array}{l}\text { Annual survival probability age } \\
0\end{array}$ & & 43 & 2 \\
\hline$S_{1}$ & 0.816 & 0.0393 & - & $\begin{array}{l}\text { Annual survival probability age } \\
1\end{array}$ & & 43 & 2 \\
\hline$S_{2}$ & 0.884 & 0.0293 & - & $\begin{array}{l}\text { Annual survival probability age } \\
2\end{array}$ & & 43 & 2 \\
\hline$S_{3}$ & 0.887 & 0.0301 & - & $\begin{array}{l}\text { Annual survival probability age } \\
3\end{array}$ & & 43 & 2 \\
\hline$S_{A}$ & 0.918 & 0.0199 & - & $\begin{array}{l}\text { Adult annual survival } \\
\text { probability }\end{array}$ & & 101 & $2,3,4$ \\
\hline$a_{G m}$ & 5 & & Years & Age at recruitment & & & 1 \\
\hline
\end{tabular}

\section{Sandwich tern (Thalasseus sandvicensis)}

The matrix model for the sandwich tern (Thalasseus sandvicensis) is composed of a juvenile stage $J_{0}$ (age 0 ), an immature stage $J_{12}$ (age 1 and 2), a young adult stage $A_{34}$ (age 3 and 4 ) and an old adult stage $A_{B}$ (age $5+$ ). Immature individuals of age one and two years old are grouped into a single stage, because estimated mortality rates are identical for these ages. Recruitment in the sandwich tern occurs at age 3 (Van der Jeugd et al., 2014). Because adults aged 3 and 4 years have a significantly lower breeding success than older indiyioluals (Veen, 1977), ove defima an additional adult class for these ages. Survival and transitions betweefrastlagessaduring the non-prededing season are described by

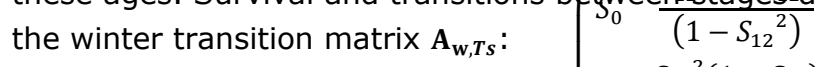

$$
\mathbf{A}_{\mathbf{w}, T s}=\mid \begin{array}{llll}
0 & \frac{S_{12}^{2}\left(1-S_{12}\right)}{S_{A}\left(1-S_{A}\right)} & 0
\end{array} .
$$

With survival of juveniles $S_{0}$, survival of imm(atures $S_{12}^{2}$ and supwival of adults $S_{A}$.

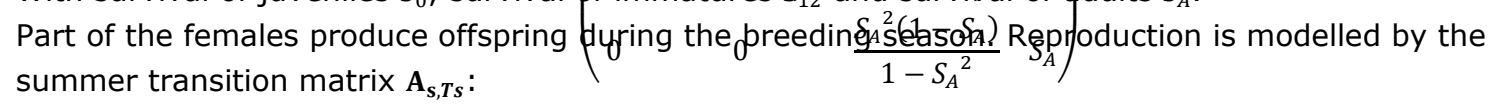

$$
\mathbf{A}_{\mathbf{s}, T s}=\left(\begin{array}{cccc}
1 & 0 & 0.3 F_{A}\left(1-P_{F}\right) & F_{A}\left(1-P_{F}\right) \\
0 & 1 & 0 & 0 \\
0 & 0 & 1 & 0 \\
0 & 0 & 0 & 1
\end{array}\right)
$$

Sandwich terns brood size varies between 1-2 eggs per brood. The breeding success parameter $F_{A}$ therefore represents number of female offspring per year. Breeding success of young females equals 0.3 times the breeding success of older females (Veen, 1977). Note that this parameter is hard coded and hence does not vary between different stochastic realization of the summer transition matrix. The probability that an adult female skips reproduction equals $P_{F}$ for both young and old females.

The annual projection matrix is calculated as $\mathbf{A}_{T s}=\mathbf{A}_{\boldsymbol{w}, \boldsymbol{T s}} \cdot \mathbf{A}_{\boldsymbol{s}, \boldsymbol{T s}}$, with 


$$
\mathbf{A}_{T S}=\left(\begin{array}{cccc}
0 & 0 & 0 & 0 \\
S_{0} & S_{12} \frac{\left(1-S_{12}\right)}{\left(1-S_{12}{ }^{2}\right)} & 0.3 F_{A}\left(1-P_{F}\right) S_{0} & F_{A}\left(1-P_{F}\right) S_{0} \\
0 & \frac{S_{12}{ }^{2}\left(1-S_{12}\right)}{\left(1-S_{12}{ }^{2}\right)} & \frac{S_{A}\left(1-S_{A}\right)}{\left(1-S_{A}{ }^{2}\right)} & 0 \\
0 & 0 & \frac{S_{A}{ }^{2}\left(1-S_{A}\right)}{\left(1-S_{A}{ }^{2}\right)} & S_{A}
\end{array}\right) .
$$

\section{Sandwich tern parameter values}

The parameter values for the sandwich tern (Table 33) are based on studies of sandwich tern colonies in the Netherlands. The value for the breeding success parameter $\left(F_{A}\right)$ is based on 82 years of data in total, from 7 different studies (Table 33). There is no information on the probability of skipping reproduction for the sandwich tern. Van Kooten et al. (2019) used values for $P_{F}$ of $0.05,0.1$ and 0.2 and here we adopt their median value of 0.1 . The standard deviation for $P_{F}$ is derived from the range rule by assuming a range of 0 to 0.5 for this parameter. The incidence of skipped breeding is equal for both adult stages. Survival probabilities are based on studies of Van der Jeugd et al. (2014) and recent data from Schekkerman et al. (2021).

Table 33. Default parameter values sandwich tern

\begin{tabular}{|c|c|c|c|c|c|c|}
\hline Symbol & Mean & SD & Unit & Description & $\begin{array}{l}\text { Years } \\
\text { of data }\end{array}$ & Source \\
\hline$F_{A}$ & 0.325 & 0.160 & \# / year & Fledged female offspring & 82 & $1-7$ \\
\hline$P_{F}$ & 0.1 & 0.125 & - & $\begin{array}{l}\text { Skipped breeding probability, all } \\
\text { adult stages }\end{array}$ & & \\
\hline$S_{0}$ & 0.508 & 0.0917 & - & $\begin{array}{l}\text { Annual survival probability } \\
\text { juveniles, age } 0\end{array}$ & 51 & 7 \\
\hline$S_{12}$ & 0.777 & 0.0518 & - & $\begin{array}{l}\text { Annual survival probability } \\
\text { immatures, age } 1 \text { and } 2\end{array}$ & 51 & 1,7 \\
\hline$S_{A}$ & 0.942 & 0.108 & - & $\begin{array}{l}\text { Annual survival probability } \\
\text { adults, age } 3+\end{array}$ & 51 & 1,7 \\
\hline$a_{T m}$ & 3 & - & Years & \multicolumn{2}{|c|}{ Age at maturation } & 7 \\
\hline \multicolumn{7}{|c|}{${ }^{1}$ (Schekkerman et al., 2021) ${ }^{2}$ (Derks \& De Kraker, 2005); ${ }^{3}$ (Koffijberg et al., 2017); ${ }^{4}$ (Beijersbergen, 2001) } \\
\hline
\end{tabular}

\section{Razorbill (Alca torda)}

The matrix model for the razorbill (Alca torda) is composed of a juvenile stage $J_{01}$ (age 0 and 1 ), a pre-breeding adult stage $A_{234}$ (age 2 to 4 ) and a breeding adult stage $A_{B}$ (age $5+$ ). Both pre-breeding and breeding adults have the same survival probability $S_{A}$, which differs from the survival of juveniles $S_{01}$. Survival and transitions between stages during the non-breeding season are described by winter transition matrix $\mathbf{A}_{\mathbf{w}, A t}$ :

$$
\mathbf{A}_{\mathbf{w}, A t}=\left(\begin{array}{ccc}
\frac{S_{01}\left(1-S_{01}\right)}{\left(1-S_{01}{ }^{2}\right)} & 0 & 0 \\
\frac{S_{01}{ }^{2}\left(1-S_{01}\right)}{\left(1-S_{01}{ }^{2}\right)} & S_{A} \frac{\left(1-S_{A}{ }^{2}\right)}{\left(1-S_{A}{ }^{3}\right)} & 0 \\
0 & S_{A}{ }^{3} \frac{\left(1-S_{A}\right)}{\left(1-S_{A}{ }^{3}\right)} & S_{A}
\end{array}\right) .
$$

A fraction $P_{F}$ of the breeding adult females skip reproduction each year. Females that do reproduce lay one egg and produce $F_{A}$ chicks each year. Reproduction during the breeding season is modelled by the summer transition matrix $\mathbf{A}_{\mathbf{s}, A t}$ :

$$
\mathbf{A}_{\mathrm{s}, A t}=\left(\begin{array}{ccc}
1 & 0 & \frac{F_{A}}{2}\left(1-P_{F}\right) \\
0 & 1 & 0 \\
0 & 0 & 1
\end{array}\right) .
$$


The annual projection matrix is calculated as $\mathbf{A}_{\boldsymbol{A t}}=\mathbf{A}_{\mathbf{w}, \boldsymbol{A t}} \cdot \mathbf{A}_{\mathbf{s}, \boldsymbol{A t}}$, which leads to

$$
\mathbf{A}_{A t}=\left(\begin{array}{ccc}
\frac{S_{01}\left(1-S_{01}\right)}{\left(1-S_{01}{ }^{2}\right)} & 0 & \frac{F_{A}}{2}\left(1-P_{F}\right) \frac{S_{01}\left(1-S_{01}\right)}{\left(1-S_{01}{ }^{2}\right)} \\
\frac{S_{01}{ }^{2}\left(1-S_{01}\right)}{\left(1-S_{01}{ }^{2}\right)} & S_{A} \frac{\left(1-S_{A}{ }^{2}\right)}{\left(1-S_{A}{ }^{3}\right)} & \frac{F_{A}}{2}\left(1-P_{F}\right) \frac{S_{01}{ }^{2}\left(1-S_{01}\right)}{\left(1-S_{01}{ }^{2}\right)} \\
0 & S_{A}{ }^{3} \frac{\left(1-S_{A}\right)}{\left(1-S_{A}{ }^{3}\right)} & S_{A}
\end{array}\right) .
$$

\section{Razorbill parameter values}

Parameter values for the razorbill (Table 34) were taken from various studies on colonies in the UK and Ireland. The mean value of the breeding success parameter $F_{A}$ is based on 85 years of data from 7 different colonies. Horswill \& Robinson (2015) report an estimate of only $3 \%$ for the incidence of missed breeding from a study by Harris \& Wanless (1989). We used this value as mean for parameter $P_{F}$, because it is based on species-specific observations. We calculated the SD for this parameter from the range rule using a range of $0-0.5$.

Values of immature survival $S_{01}$ are based on colonies at Skokholm, Wales (Lloyd \& Perrins, 1977) and in the Britain and Irish Sea (Lloyd, 1974). Values for adult survival are based on 4 colonies around the UK, and 1 colony at Hornøya, Norway (Sandvik et al., 2005).

Table 34. Default parameter values razorbill

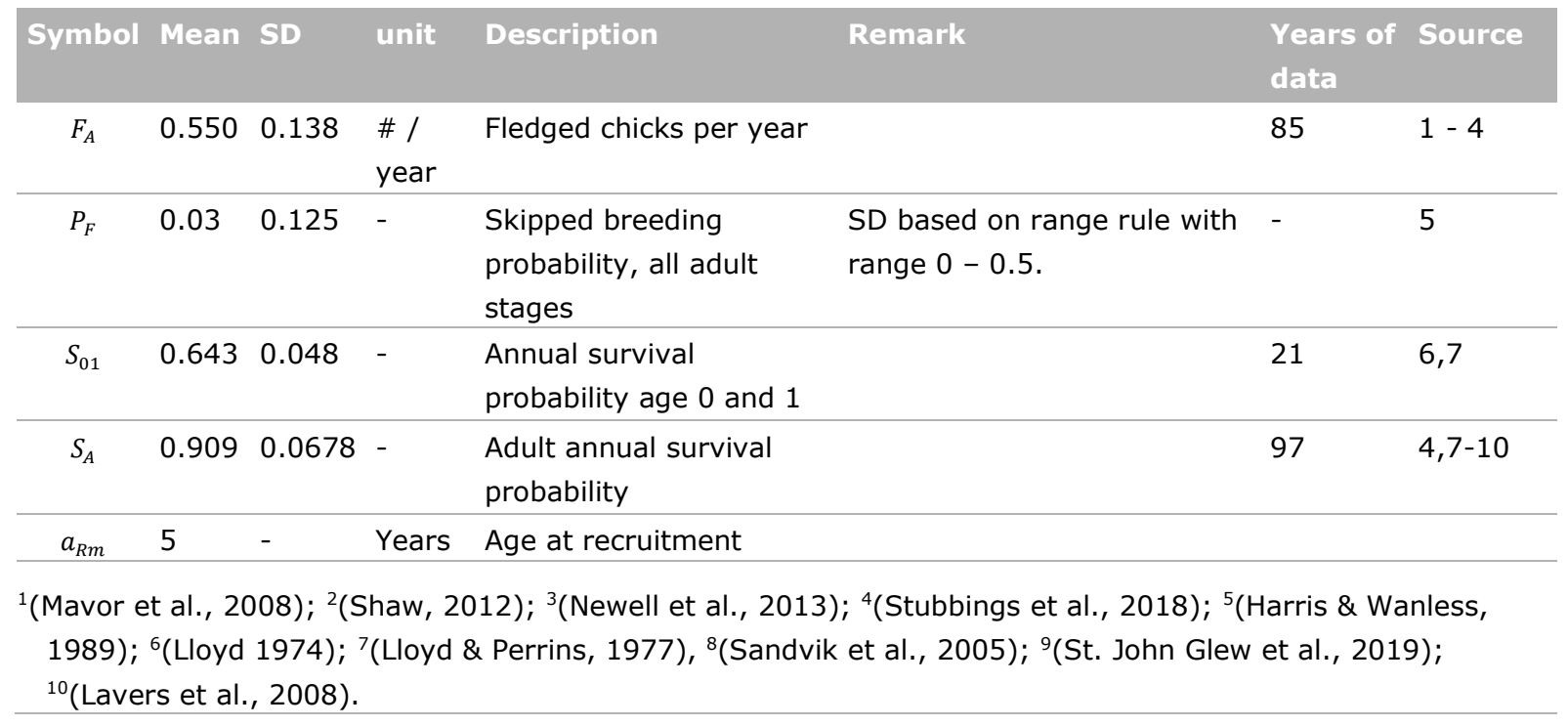

\section{Common guillemot (Uria aalge)}

The matrix model for the common guillemot (Uria aalge) is composed of three juvenile life stages; $J_{0}$ (age 0 ), $J_{1}$ (age 1 ) and $J_{2}$ (age 2), a pre-breeding adult life stage (age 3-5) and a breeding adult life stage $A_{B}$ (age $6+$ ). Each juvenile life stage has its own survival parameter, $S_{0}, S_{1}$ and $S_{2}$. Pre-breeding and breeding adult have survival probability $S_{A}$. Survival and transitions between stages during the non-breeding season are described by winter transition matrix $\mathbf{A}_{\mathbf{w}, \boldsymbol{U a}}$ :

$$
\mathbf{A}_{\mathbf{w}, \text { Ua }}=\left(\begin{array}{ccccc}
0 & 0 & 0 & 0 & 0 \\
S_{0} & 0 & 0 & 0 & 0 \\
0 & S_{1} & 0 & 0 & 0 \\
0 & 0 & S_{2} & \frac{S_{A}\left(1-S_{A}{ }^{2}\right)}{\left(1-S_{A}{ }^{3}\right)} & 0 \\
0 & 0 & 0 & \frac{S_{A}{ }^{3}\left(1-S_{A}\right)}{\left(1-S_{A}{ }^{3}\right)} & S_{A}
\end{array}\right) .
$$

A fraction $P_{F}$ of the breeding adult females skip reproduction each year. Because the maximum clutch size is one egg, the breeding success parameter $F_{A}$ represents the number of fledged chicks per breeding female. Reproduction during the breeding season is modelled by the summer transition matrix $\mathbf{A}_{\mathrm{s}, \boldsymbol{U a}}$ : 


$$
\mathbf{A}_{\mathbf{s}, U \boldsymbol{a}}=\left(\begin{array}{ccccc}
1 & 0 & 0 & 0 & \frac{F_{A}}{2}\left(1-P_{F}\right) \\
0 & 1 & 0 & 0 & 0 \\
0 & 0 & 1 & 0 & 0 \\
0 & 0 & 0 & 1 & 0 \\
0 & 0 & 0 & 0 & 1
\end{array}\right)
$$

The annual projection matrix is calculated as $\mathbf{A}_{\boldsymbol{U} \boldsymbol{a}}=\mathbf{A}_{\mathbf{w}, \boldsymbol{U a}} \cdot \mathbf{A}_{\mathbf{s}, \boldsymbol{U a}}$, which leads to

$$
\mathbf{A}_{U \boldsymbol{u}}=\left(\begin{array}{ccccc}
0 & 0 & 0 & 0 & 0 \\
S_{0} & 0 & 0 & 0 & \frac{F_{A}}{2}\left(1-P_{F}\right) S_{0} \\
0 & S_{1} & 0 & 0 & 0 \\
0 & 0 & S_{2} & \frac{S_{A}\left(1-S_{A}{ }^{2}\right)}{\left(1-S_{A}{ }^{3}\right)} & 0 \\
0 & 0 & 0 & \frac{S_{A}{ }^{3}\left(1-S_{A}\right)}{\left(1-S_{A}{ }^{3}\right)} & S_{A}
\end{array}\right) .
$$

\section{Common guillemot parameter values}

Parameter values for the common guillemot are reported in Table 35. There are numerous studies that report life-history parameters for this species. Mean and standard deviation for breeding success parameter $F_{A}$ were obtained from five studies covered a total of 194 years of data. The mean and standard deviation for $P_{F}$ are based on a single study of birds from the Isle of May, Scotland covering 33 years (Reed et al., 2015). Survival probabilities were derived from birds at Skomer, Wales and the Isle of May and Canna Isles, Scotland. Sandvik et al. (2005) also report values for adult survival from birds at Hornøya, Norway.

\begin{tabular}{|c|c|c|c|c|c|c|c|}
\hline Symbol & Mean & SD & Unit & Description & Remark & $\begin{array}{l}\text { Years } \\
\text { of } \\
\text { data }\end{array}$ & source \\
\hline$F_{A}$ & 0.664 & 0.149 & $\begin{array}{l}\# / \\
\text { year }\end{array}$ & fledged offspring & $\begin{array}{l}\text { area specific } \\
\text { estimates (UK), } \\
\text { available }\end{array}$ & 194 & $1-5$ \\
\hline$P_{F}$ & 0.07 & 0.03 & - & $\begin{array}{l}\text { skipped breeding } \\
\text { probability }\end{array}$ & $\begin{array}{l}\text { SD based on range } \\
\text { rule using range } \\
0.02-0.14\end{array}$ & 33 & 6 \\
\hline$S_{0}$ & 0.608 & 0.132 & - & $\begin{array}{l}\text { annual survival } \\
\text { probability age } 0\end{array}$ & & 68 & 7,10 \\
\hline$S_{1}$ & 0.774 & 0.112 & - & $\begin{array}{l}\text { annual survival } \\
\text { probability age } 1\end{array}$ & & 64 & $7,8,10$ \\
\hline$S_{2}$ & 0.858 & 0.0736 & - & $\begin{array}{l}\text { annual survival } \\
\text { probability age } 2\end{array}$ & & 64 & $7,8,10$ \\
\hline$S_{A}$ & 0.949 & 0.0447 & - & $\begin{array}{l}\text { annual survival } \\
\text { probability adults } \\
\text { age } 3+\end{array}$ & & & $7-10$ \\
\hline$a_{U M}$ & 6 & - & Years & $\begin{array}{l}\text { age at } \\
\text { recruitment }\end{array}$ & & & 1 \\
\hline
\end{tabular}

Table 35. Default parameter values common guillemot

\section{Northern fulmar (Fulmarus glacialis)}

The matrix model for the northern fulmar (Fulmarus glacialis) is composed of a juvenile stage $J$, a prebreeding adult stage $A_{P B}$ and a breeding adult life stage $A_{B}$. The ages that correspond to each life stage depend on the duration (in years) of the juvenile and pre-breeding adult life stages, which are parameters in northern fulmar matrix model. Survival rates of juveniles $\left(S_{J}\right)$ differ from survival of prebreeding and breeding adults $\left(S_{A}\right)$. Survival and transitions between stages during the non-breeding season are described by winter transition matrix $\mathbf{A}_{\mathbf{w}, \mathbf{F g}}$ : 


$$
\mathbf{A}_{\mathbf{w}, F \boldsymbol{F}}=\left(\begin{array}{ccc}
\frac{S_{J}\left(1-S_{J}{ }^{N_{J}-1}\right)}{\left(1-S_{J}{ }^{J}\right)} & 0 & 0 \\
\frac{S_{J}^{N_{J}}\left(1-S_{J}\right)}{\left(1-S_{J}^{N_{J}}\right)} & S_{A} \frac{\left(1-S_{A}{ }^{N_{P B}-1}\right)}{\left(1-S_{A}^{N_{P B}}\right)} & 0 \\
0 & S_{A}{ }^{{ }^{N} P B} \frac{\left(1-S_{A}\right)}{\left(1-S_{A}{ }^{N_{P B}}\right)} & S_{A}
\end{array}\right)
$$

Here, $N_{J}$ represents the number of juvenile age classes and $N_{P B}$ is the number of pre-breeding age classes. Note that these parameters can only take whole numbers (integer values).

A fraction $P_{F}$ of the breeding adult females skip reproduction each year. Because females only lay a single egg, the breeding success parameter $F_{A}$ represents the number of fledged chicks per breeding female per year. Reproduction during the breeding season is modelled by the summer transition matrix $\mathbf{A}_{\mathbf{s}, \mathrm{F} g}$ :

$$
\mathbf{A}_{\mathbf{s}, \boldsymbol{F} g}=\left(\begin{array}{ccc}
1 & 0 & \frac{F_{A}}{2}\left(1-P_{F}\right) \\
0 & 1 & 0 \\
0 & 0 & 1
\end{array}\right)
$$

The annual projection matrix is calculated as $\mathbf{A}_{F g}=\mathbf{A}_{\mathbf{w}, F g} \cdot \mathbf{A}_{\mathbf{s}, F g}$, which leads to

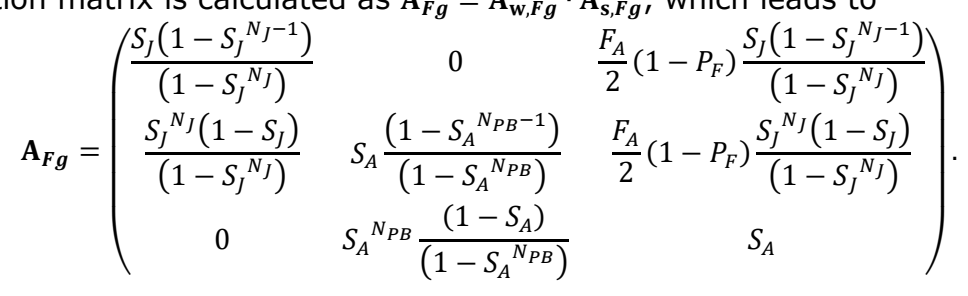

\section{Northern fulmar parameter values}

Parameter values for the northern fulmar are reported in Table 36. Mean and standard deviation for breeding success parameter $F_{A}$ were obtained from five studies of four different Island around the UK that covered 108 years of data in total. The mean and standard deviation for $P_{F}$ are based on a single study of birds from Eynhallow, Orkney Islands, Scotland covering 36 years (Thompson \& Ollason, 2001). Juvenile survival was calculated from survival across the immature years of the southern fulmar at Île des Pétrels, Antarctica. Jenouvrier et al. (2003) report a survival probability across age 0 to 11 of 0.26 , which corresponds to an annual survival of 0.884 . Female age at first breeding is at least 10 years (Ollason \& Dunnet, 1978) and we assumed that during six of those years individuals experience juvenile mortality rates, while the remaining four years they experience adult mortality rates. Like the matrix models for the other species, we do not consider variation in the length of the juvenile and the pre-breeding adult stage. 
Table 36. Default parameter values northern fulmar

\begin{tabular}{|c|c|c|c|c|c|c|c|}
\hline Symbol & Mean & SD & Unit & Description & Remark & $\begin{array}{l}\text { Years } \\
\text { of data }\end{array}$ & source \\
\hline$F_{A}$ & 0.42 & 0.13 & $\begin{array}{l}\text { \# / } \\
\text { year }\end{array}$ & fledged offspring & & 108 & $1-5$ \\
\hline$P_{F}$ & 0.304 & 0.113 & - & $\begin{array}{l}\text { skipped breeding } \\
\text { probability }\end{array}$ & & 36 & 6 \\
\hline$S_{J}$ & 0.884 & 0.054 & - & $\begin{array}{l}\text { annual survival } \\
\text { probability } \\
\text { juveniles }\end{array}$ & Southern fulmar & 39 & 7 \\
\hline$S_{A}$ & 0.936 & 0.055 & - & $\begin{array}{l}\text { annual survival } \\
\text { probability adults }\end{array}$ & & 34 & 8 \\
\hline$N_{J}$ & 6 & - & Years & $\begin{array}{l}\text { Number of } \\
\text { juvenile ages }\end{array}$ & $\begin{array}{l}\text { No variation was } \\
\text { considered for } \\
\text { this parameter }\end{array}$ & & \\
\hline$N_{P B}$ & 4 & - & Years & $\begin{array}{l}\text { Number of pre- } \\
\text { breeding adult } \\
\text { ages }\end{array}$ & $\begin{array}{l}\text { No variation was } \\
\text { considered for } \\
\text { this parameter }\end{array}$ & & \\
\hline$a_{B}$ & 10 & - & Years & $\begin{array}{l}\text { Female age at } \\
\text { first breeding }\end{array}$ & & & 9 \\
\hline \multicolumn{8}{|c|}{$\begin{array}{l}\left.\left.\left.{ }^{1} \text { (Lewis et al., 2009); }{ }^{2} \text { (Newell et al., } 2013\right) ;{ }^{3} \text { (Newell et al., } 2016\right) ;{ }^{4} \text { (Stubbings et al., } 2018\right){ }^{5}(\text { Shaw et } \\
\text { al., 2002); }{ }^{6} \text { (Thompson \& Ollason, 2001); }{ }^{7} \text { (Jenouvrier et al., 2003); }{ }^{8} \text { (Grosbois \& Thompson, 2005); } \\
{ }^{9} \text { (Ollason \& Dunnet, 1978) }\end{array}$} \\
\hline
\end{tabular}

\section{Atlantic puffin (Fratercula arctica)}

The matrix model for the Atlantic puffin (Fratercula arctica) is composed of three immature stages, $J_{03}$ (age $0-3$ ), $J_{4}$ (age 4) and $J_{5}$ (age 5), and an adult stage $A$ (age $5+$ ). Immature individuals aged one to three years old are grouped into a single stage, because the estimated survival rate $\left(S_{03}\right)$ is identical across these ages. Survival probabilities are different for four $\left(S_{4}\right)$ and five $\left(S_{5}\right)$ year old individuals, and for adults $\left(S_{A}\right)$. Survival and transitions between stages during the non-breeding season are described by the winter transition matrix $\mathbf{A}_{\mathbf{w}, \boldsymbol{F a}}$ :

$$
\mathbf{A}_{\mathbf{w}, \boldsymbol{F a}}=\left(\begin{array}{cccc}
\frac{S_{03}\left(1-S_{03}^{3}\right)}{\left(1-S_{03}{ }^{4}\right)} & 0 & 0 & 0 \\
\frac{S_{03}{ }^{4}\left(1-S_{03}\right)}{\left(1-S_{03}{ }^{4}\right)} & 0 & 0 & 0 \\
0 & S_{4} & 0 & 0 \\
0 & 0 & S_{5} & S_{A}
\end{array}\right) .
$$

Most individuals start breeding when they are at least 6 years old, but some individuals breed earlier. We therefore allow 4 and 5 year old individuals to produce offspring with a separate probability to skip breeding for these life stages $\left(P_{F 4}\right.$ and $\left.P_{F 5}\right)$. Reproduction is modelled by the summer transition matrix $\mathrm{A}_{\mathrm{s}, \mathrm{Fa}}$ :

$$
\mathbf{A}_{\mathbf{s}, \boldsymbol{F a}}=\left(\begin{array}{cccc}
1 & \left(1-P_{F 4}\right) \frac{F_{A}}{2} & \left(1-P_{F 5}\right) \frac{F_{A}}{2} & \left(1-P_{F}\right) \frac{F_{A}}{2} \\
0 & 1 & 0 & 0 \\
0 & 0 & 1 & 0 \\
0 & 0 & 0 & 1
\end{array}\right)
$$

Breeding success parameter $F_{A}$ represents the number of offspring per year, as Atlantic puffin females lay a single egg at a time. The probability that an adult female skips reproduction equals $P_{F}$. The annual projection matrix is calculated as $\mathbf{A}_{\boldsymbol{F a}}=\mathbf{A}_{\boldsymbol{w}, \boldsymbol{F a}} \cdot \mathbf{A}_{\boldsymbol{s}, \boldsymbol{F a}}$, with 


$$
\mathbf{A}_{F a}=\left(\begin{array}{cccc}
\frac{S_{03}\left(1-S_{03}^{3}\right)}{\left(1-S_{03}{ }^{4}\right)} & \left(1-P_{F 4}\right) \frac{F_{A}}{2} \frac{S_{03}\left(1-S_{03}^{3}\right)}{\left(1-S_{03}{ }^{4}\right)} & \left(1-P_{F 5}\right) \frac{F_{A}}{2} \frac{S_{03}\left(1-S_{03}^{3}\right)}{\left(1-S_{03}{ }^{4}\right)} & \left(1-P_{F}\right) \frac{F_{A}}{2} \frac{S_{03}\left(1-S_{03}^{3}\right)}{\left(1-S_{03}{ }^{4}\right)} \\
\frac{S_{03}{ }^{4}\left(1-S_{03}\right)}{\left(1-S_{03}{ }^{4}\right)} & \left(1-P_{F 4}\right) \frac{F_{A}}{2} \frac{S_{03}\left(1-S_{03}\right)}{\left(1-S_{03}{ }^{4}\right)} & \left(1-P_{F 5}\right) \frac{F_{A}}{2} \frac{S_{03}{ }^{4}\left(1-S_{03}\right)}{\left(1-S_{03}{ }^{4}\right)} & \left(1-P_{F}\right) \frac{F_{A} \frac{S_{03}{ }^{4}\left(1-S_{03}\right)}{2}}{\left(1-S_{03}{ }^{4}\right)} \\
0 & S_{4} & 0 & 0 \\
0 & 0 & S_{5} & S_{A}
\end{array}\right) .
$$

\section{Atlantic puffin parameter values}

Parameter values for the Atlantic puffin (Table 37) are mainly based on studies from the UK. Estimates for breeding success were derived from several colonies around the UK. The values for the skipped breeding probability for four and five year olds account for the proportion of individuals that only start breeding at age 6 (Harris \& Wanless, 2011). Once breeding starts, Atlantic puffins attempt to breed almost every year (Ashcroft, 1979, Lowther et al., 2020), which translates in the low value for $P_{F}$. Values for immature survival are based on a metapopulation study of four colonies in the Gulf of Maine, USA and Canada (Breton et al., 2006). Adult survival rates are based on three UK colonies and two colonies in Norway.

Table 37. Default parameter values Atlantic puffin

\begin{tabular}{|c|c|c|c|c|c|c|}
\hline Symbol & Mean & SD & Unit & Description & $\begin{array}{l}\text { Years } \\
\text { of data }\end{array}$ & Source \\
\hline$F_{A}$ & 0.70 & 0.11 & \# / year & Fledged offspring & 60 & $1-6$ \\
\hline$P_{F 4}$ & 0.6 & 0.01 & - & \multicolumn{2}{|l|}{$\begin{array}{l}\text { Skipped breeding probability, } 4 \\
\text { year olds }\end{array}$} & 7 \\
\hline$P_{F 5}$ & 0.3 & 0.01 & - & \multicolumn{2}{|l|}{$\begin{array}{l}\text { Skipped breeding probability, } 5 \\
\text { year olds }\end{array}$} & 7 \\
\hline$P_{F}$ & 0.078 & 0.01 & - & $\begin{array}{l}\text { Skipped breeding probability, } \\
\text { adults }\end{array}$ & 3 & 8 \\
\hline$S_{03}$ & 0.71 & 0.11 & - & $\begin{array}{l}\text { Annual survival probability } \\
\text { juveniles, age } 0-3\end{array}$ & 24 & 9 \\
\hline$S_{4}$ & 0.78 & 0.092 & - & $\begin{array}{l}\text { Annual survival probability age } 4 \\
\text { individuals }\end{array}$ & 24 & 9 \\
\hline$S_{5}$ & 0.80 & 0.083 & - & $\begin{array}{l}\text { Annual survival probability age } 5 \\
\text { individuals }\end{array}$ & 24 & 9 \\
\hline$S_{A}$ & 0.93 & 0.057 & - & Annual survival probability adults & 81 & 4,10 \\
\hline \multicolumn{7}{|c|}{$\begin{array}{l}{ }^{1} \text { (Mavor et al., 2008); }{ }^{2} \text { (Shaw et al., 2002); }{ }^{3} \text { (Newell et al., 2016); }{ }^{4} \text { (Harris et al., 2013); }{ }^{5} \text { (Stubbings et al. } \\
\text { 2018); }{ }^{6} \text { (Fayet et al., 2017); }{ }^{7} \text { (Harris \& Wanless, 2011); }{ }^{8} \text { (Ashcroft, 1979); }{ }^{9} \text { (Breton et al., 2006); }{ }^{10} \text { (Harris } \\
\text { et al., 2005) }\end{array}$} \\
\hline
\end{tabular}




\section{Annex 2 Number of casualties for Dutch OWF areas}

Table 38: Estimated number of casualties due to habitat loss from Dutch OWFs per OWF id, species and bimonthly period. Areas corresponding to the OWF IDs are shown in Figure 6 and their names can be found in Table 10.

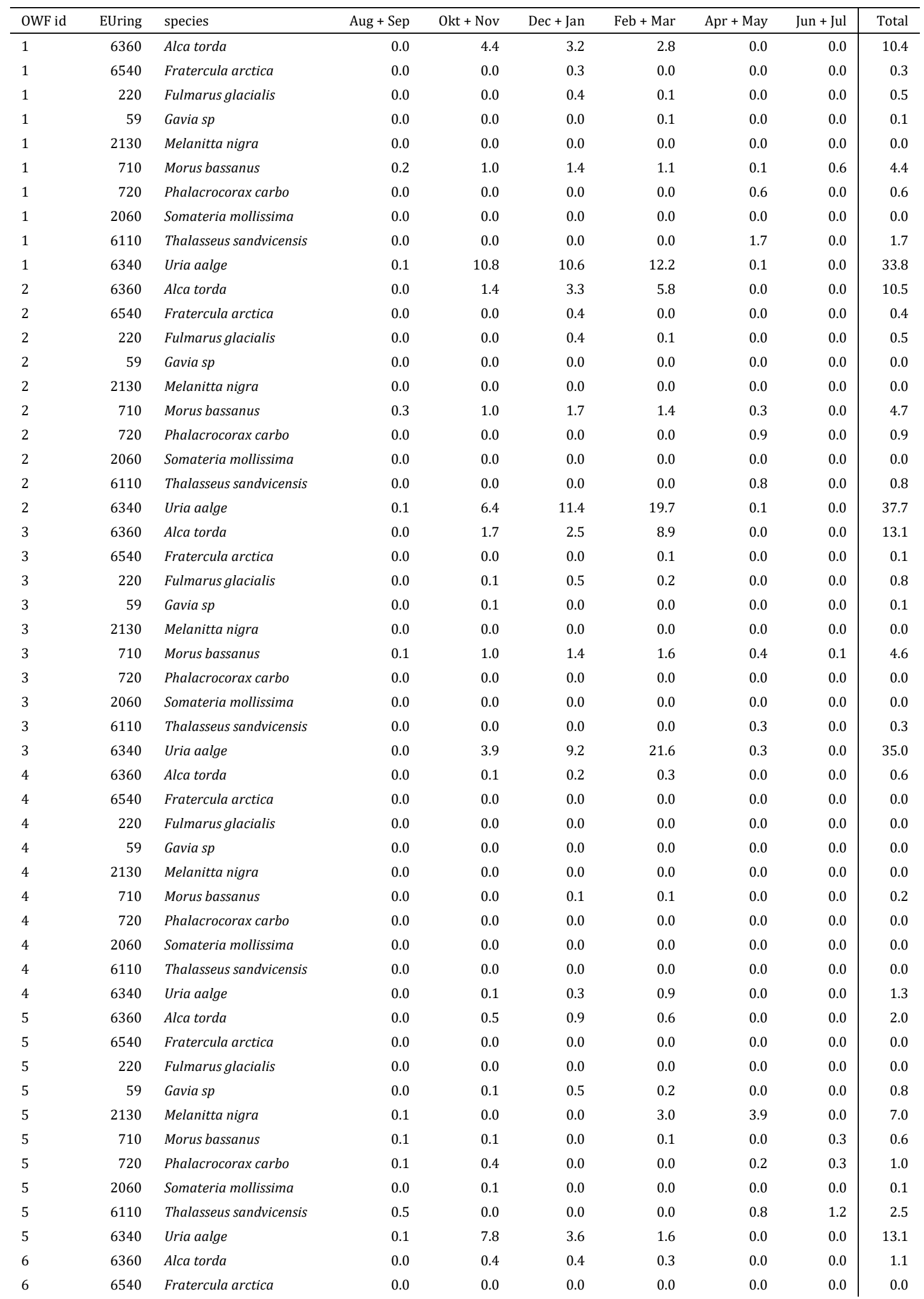




\begin{tabular}{|c|c|c|c|c|c|c|c|}
\hline 220 & Fulmarus glacialis & 0.0 & 0.0 & 0.0 & 0.0 & 0.0 & 0.0 \\
\hline 59 & Gavia sp & 0.0 & 0.0 & 0.0 & 0.0 & 0.0 & 0.0 \\
\hline 2130 & Melanitta nigra & 0.0 & 0.0 & 0.0 & 0.0 & 0.0 & 0.0 \\
\hline 710 & Morus bassanus & 0.0 & 0.1 & 0.0 & 0.1 & 0.1 & 0.0 \\
\hline 720 & Phalacrocorax carbo & 0.0 & 0.0 & 0.0 & 0.0 & 0.0 & 0.0 \\
\hline 2060 & Somateria mollissima & 0.0 & 0.0 & 0.0 & 0.0 & 0.0 & 0.0 \\
\hline 6110 & Thalasseus sandvicensis & 0.0 & 0.0 & 0.0 & 0.0 & 0.4 & 0.0 \\
\hline 6340 & Uria aalge & 0.0 & 2.6 & 3.8 & 1.3 & 0.1 & 0.0 \\
\hline 6360 & Alca torda & 0.0 & 0.2 & 0.5 & 1.1 & 0.0 & 0.0 \\
\hline 6540 & Fratercula arctica & 0.0 & 0.0 & 0.0 & 0.0 & 0.0 & 0.0 \\
\hline 220 & Fulmarus glacialis & 0.0 & 0.0 & 0.0 & 0.0 & 0.0 & 0.0 \\
\hline 59 & Gavia $s p$ & 0.0 & 0.0 & 0.0 & 0.2 & 0.0 & 0.0 \\
\hline 2130 & Melanitta nigra & 0.0 & 0.0 & 0.0 & 0.0 & 0.0 & 0.0 \\
\hline 710 & Morus bassanus & 0.1 & 0.0 & 0.1 & 0.0 & 0.1 & 0.0 \\
\hline 720 & Phalacrocorax carbo & 0.0 & 0.0 & 0.0 & 0.0 & 0.0 & 0.1 \\
\hline 2060 & Somateria mollissima & 0.0 & 0.0 & 0.0 & 0.0 & 0.0 & 0.0 \\
\hline 6110 & Thalasseus sandvicensis & 0.0 & 0.0 & 0.0 & 0.0 & 0.1 & 0.2 \\
\hline 6340 & Uria aalge & 0.0 & 3.1 & 3.8 & 1.5 & 0.1 & 0.0 \\
\hline 6360 & Alca torda & 0.0 & 0.9 & 0.8 & 1.0 & 0.1 & 0.0 \\
\hline 6540 & Fratercula arctica & 0.0 & 0.0 & 0.0 & 0.0 & 0.0 & 0.0 \\
\hline 220 & Fulmarus glacialis & 0.9 & 0.1 & 0.1 & 0.0 & 0.1 & 0.0 \\
\hline 59 & Gavia $s p$ & 0.0 & 0.0 & 0.0 & 0.0 & 0.2 & 0.0 \\
\hline 2130 & Melanitta nigra & 0.0 & 0.0 & 0.0 & 0.0 & 0.0 & 0.0 \\
\hline 710 & Morus bassanus & 0.2 & 0.3 & 0.0 & 0.0 & 0.0 & 0.1 \\
\hline 720 & Phalacrocorax carbo & 0.0 & 0.0 & 0.0 & 0.0 & 0.0 & 0.0 \\
\hline 2060 & Somateria mollissima & 0.0 & 0.0 & 0.0 & 0.0 & 0.0 & 0.0 \\
\hline 6110 & Thalasseus sandvicensis & 0.4 & 0.0 & 0.0 & 0.0 & 0.1 & 0.0 \\
\hline 6340 & Uria aalge & 2.3 & 2.4 & 4.3 & 1.0 & 0.7 & 0.3 \\
\hline 6360 & Alca torda & 0.0 & 0.1 & 0.2 & 1.0 & 0.2 & 0.0 \\
\hline 6540 & Fratercula arctica & 0.0 & 0.0 & 0.1 & 0.0 & 0.0 & 0.0 \\
\hline 220 & Fulmarus glacialis & 0.0 & 0.0 & 0.0 & 0.0 & 0.1 & 0.0 \\
\hline 59 & Gavia sp & 0.0 & 0.0 & 0.0 & 0.0 & 0.5 & 0.0 \\
\hline 2130 & Melanitta nigra & 0.0 & 0.0 & 0.0 & 0.0 & 0.0 & 0.0 \\
\hline 710 & Morus bassanus & 0.0 & 0.0 & 0.0 & 0.0 & 0.1 & 0.0 \\
\hline 720 & Phalacrocorax carbo & 0.0 & 0.0 & 0.0 & 0.0 & 0.0 & 0.0 \\
\hline 2060 & Somateria mollissima & 0.0 & 0.0 & 0.0 & 0.0 & 0.0 & 0.0 \\
\hline 6110 & Thalasseus sandvicensis & 0.1 & 0.0 & 0.0 & 0.0 & 0.0 & 0.0 \\
\hline 6340 & Uria aalge & 1.9 & 3.8 & 2.3 & 0.3 & 1.0 & 0.0 \\
\hline 6360 & Alca torda & 0.0 & 1.9 & 1.8 & 3.7 & 0.2 & 0.0 \\
\hline 6540 & Fratercula arctica & 0.0 & 0.0 & 0.0 & 0.0 & 0.0 & 0.0 \\
\hline 220 & Fulmarus glacialis & 0.0 & 0.0 & 0.0 & 0.1 & 0.0 & 0.0 \\
\hline 59 & Gavia sp & 0.0 & 0.0 & 1.1 & 0.9 & 0.1 & 0.0 \\
\hline 2130 & Melanitta nigra & 0.0 & 0.0 & 0.0 & 0.0 & 0.0 & 0.0 \\
\hline 710 & Morus bassanus & 0.4 & 0.2 & 0.1 & 0.0 & 0.3 & 0.2 \\
\hline 720 & Phalacrocorax carbo & 0.0 & 0.0 & 0.0 & 0.0 & 0.0 & 0.3 \\
\hline 2060 & Somateria mollissima & 0.0 & 0.0 & 2.0 & 0.0 & 0.0 & 0.0 \\
\hline 6110 & Thalasseus sandvicensis & 0.6 & 0.0 & 0.0 & 0.0 & 0.6 & 0.4 \\
\hline 6340 & Uria aalge & 0.1 & 8.0 & 13.8 & 3.7 & 0.4 & 0.4 \\
\hline 6360 & Alca torda & 0.0 & 5.0 & 1.2 & 0.5 & 0.1 & 0.0 \\
\hline 6540 & Fratercula arctica & 0.0 & 0.0 & 0.0 & 0.0 & 0.0 & 0.0 \\
\hline 220 & Fulmarus glacialis & 0.0 & 0.0 & 0.0 & 0.0 & 0.0 & 0.0 \\
\hline 59 & Gavia sp & 0.0 & 0.0 & 0.0 & 0.0 & 0.0 & 0.0 \\
\hline 2130 & Melanitta nigra & 0.0 & 0.0 & 0.0 & 0.1 & 0.0 & 0.0 \\
\hline 710 & Morus bassanus & 0.0 & 0.2 & 0.5 & 0.0 & 0.1 & 0.0 \\
\hline 720 & Phalacrocorax carbo & 0.0 & 0.0 & 0.0 & 0.0 & 0.0 & 0.0 \\
\hline 2060 & Somateria mollissima & 0.0 & 0.0 & 1.8 & 0.0 & 0.0 & 0.0 \\
\hline 6110 & Thalasseus sandvicensis & 0.6 & 0.0 & 0.0 & 0.0 & 0.2 & 0.1 \\
\hline 6340 & Uria aalge & 0.0 & 18.3 & 9.0 & 3.4 & 0.2 & 0.0 \\
\hline 6360 & Alca torda & 0.0 & 0.9 & 1.2 & 0.6 & 0.0 & 0.0 \\
\hline 6540 & Fratercula arctica & 0.0 & 0.0 & 0.0 & 0.0 & 0.0 & 0.0 \\
\hline 220 & Fulmarus glacialis & 0.0 & 0.0 & 0.0 & 0.0 & 0.0 & 0.0 \\
\hline 59 & Gavia $s p$ & 0.0 & 0.0 & 0.2 & 0.0 & 0.0 & 0.0 \\
\hline 2130 & Melanitta nigra & 0.0 & 0.0 & 0.0 & 0.0 & 0.0 & 0.0 \\
\hline
\end{tabular}




\begin{tabular}{|c|c|c|c|c|c|c|c|c|c|}
\hline 12 & 710 & Morus bassanus & 0.0 & 0.2 & 0.4 & 0.0 & 0.2 & 0.0 & 0.8 \\
\hline 12 & 720 & Phalacrocorax carbo & 0.0 & 0.0 & 0.0 & 0.0 & 0.0 & 0.0 & 0.0 \\
\hline 12 & 2060 & Somateria mollissima & 0.0 & 0.0 & 0.3 & 0.0 & 0.0 & 0.0 & 0.3 \\
\hline 12 & 6110 & Thalasseus sandvicensis & 0.0 & 0.0 & 0.0 & 0.0 & 0.4 & 0.1 & 0.5 \\
\hline 12 & 6340 & Uria aalge & 0.0 & 8.6 & 8.0 & 2.2 & 0.0 & 0.0 & 18.8 \\
\hline 13 & 6360 & Alca torda & 0.0 & 1.0 & 1.6 & 1.0 & 0.0 & 0.0 & 3.6 \\
\hline 13 & 6540 & Fratercula arctica & 0.0 & 0.0 & 0.0 & 0.0 & 0.0 & 0.0 & 0.0 \\
\hline 13 & 220 & Fulmarus glacialis & 0.0 & 0.0 & 0.0 & 0.0 & 0.0 & 0.0 & 0.0 \\
\hline 13 & 59 & Gavia $s p$ & 0.0 & 0.0 & 0.2 & 0.2 & 0.1 & 0.0 & 0.5 \\
\hline 13 & 2130 & Melanitta nigra & 0.0 & 0.0 & 0.0 & 0.0 & 0.0 & 0.0 & 0.0 \\
\hline 13 & 710 & Morus bassanus & 0.2 & 0.2 & 0.1 & 0.1 & 0.3 & 0.1 & 1.0 \\
\hline 13 & 720 & Phalacrocorax carbo & 0.0 & 0.0 & 0.0 & 0.0 & 0.0 & 0.0 & 0.0 \\
\hline 13 & 2060 & Somateria mollissima & 0.0 & 0.0 & 0.0 & 0.0 & 0.0 & 0.0 & 0.0 \\
\hline 13 & 6110 & Thalasseus sandvicensis & 0.3 & 0.0 & 0.0 & 0.0 & 0.6 & 0.1 & 1.0 \\
\hline 13 & 6340 & Uria aalge & 0.0 & 9.3 & 12.0 & 2.8 & 0.2 & 0.0 & 24.3 \\
\hline 14 & 6360 & Alca torda & 0.0 & 2.3 & 2.1 & 3.7 & 0.0 & 0.0 & 8.1 \\
\hline 14 & 6540 & Fratercula arctica & 0.0 & 0.0 & 0.0 & 0.0 & 0.0 & 0.0 & 0.0 \\
\hline 14 & 220 & Fulmarus glacialis & 0.0 & 0.0 & 0.5 & 0.1 & 0.0 & 0.0 & 0.6 \\
\hline 14 & 59 & Gavia sp & 0.0 & 0.0 & 0.0 & 0.2 & 0.0 & 0.0 & 0.2 \\
\hline 14 & 2130 & Melanitta nigra & 0.0 & 0.0 & 0.0 & 0.0 & 0.0 & 0.0 & 0.0 \\
\hline 14 & 710 & Morus bassanus & 0.1 & 1.0 & 1.5 & 1.4 & 0.2 & 0.3 & 4.5 \\
\hline 14 & 720 & Phalacrocorax carbo & 0.0 & 0.0 & 0.0 & 0.0 & 0.0 & 0.0 & 0.0 \\
\hline 14 & 2060 & Somateria mollissima & 0.0 & 0.0 & 0.0 & 0.0 & 0.0 & 0.0 & 0.0 \\
\hline 14 & 6110 & Thalasseus sandvicensis & 0.1 & 0.0 & 0.0 & 0.0 & 1.3 & 0.0 & 1.4 \\
\hline 14 & 6340 & Uria aalge & 0.0 & 7.8 & 6.4 & 11.5 & 0.3 & 0.0 & 26.0 \\
\hline 15 & 6360 & Alca torda & 0.0 & 3.8 & 3.6 & 8.2 & 0.3 & 0.0 & 15.9 \\
\hline 15 & 6540 & Fratercula arctica & 0.0 & 0.2 & 0.0 & 0.1 & 0.0 & 0.0 & 0.3 \\
\hline 15 & 220 & Fulmarus glacialis & 0.0 & 0.0 & 0.1 & 0.1 & 0.0 & 0.0 & 0.2 \\
\hline 15 & 59 & Gavia $s p$ & 0.0 & 0.0 & 0.2 & 0.0 & 0.0 & 0.0 & 0.2 \\
\hline 15 & 2130 & Melanitta nigra & 0.0 & 0.0 & 0.0 & 0.0 & 0.0 & 0.0 & 0.0 \\
\hline 15 & 710 & Morus bassanus & 0.2 & 0.6 & 0.1 & 0.5 & 0.0 & 0.3 & 1.7 \\
\hline 15 & 720 & Phalacrocorax carbo & 0.0 & 0.0 & 0.0 & 0.0 & 0.0 & 0.0 & 0.0 \\
\hline 15 & 2060 & Somateria mollissima & 0.0 & 0.0 & 0.0 & 0.0 & 0.0 & 0.0 & 0.0 \\
\hline 15 & 6110 & Thalasseus sandvicensis & 0.8 & 0.0 & 0.0 & 0.0 & 1.4 & 1.5 & 3.7 \\
\hline 15 & 6340 & Uria aalge & 0.5 & 27.9 & 22.5 & 6.9 & 2.4 & 0.1 & 60.3 \\
\hline bw4 & 6360 & Alca torda & 0.1 & 1.6 & 1.8 & 2.7 & 0.1 & 0.0 & 6.3 \\
\hline bw4 & 6540 & Fratercula arctica & 0.0 & 0.0 & 0.1 & 0.0 & 0.0 & 0.0 & 0.1 \\
\hline bw4 & 220 & Fulmarus glacialis & 0.6 & 0.0 & 0.1 & 0.1 & 0.0 & 0.0 & 0.8 \\
\hline bw4 & 59 & Gavia $s p$ & 0.1 & 0.0 & 0.0 & 0.1 & 0.1 & 0.0 & 0.3 \\
\hline bw4 & 2130 & Melanitta nigra & 0.0 & 0.0 & 0.0 & 0.0 & 0.0 & 0.0 & 0.0 \\
\hline bw4 & 710 & Morus bassanus & 0.2 & 0.4 & 0.1 & 0.0 & 0.1 & 0.1 & 0.9 \\
\hline bw4 & 720 & Phalacrocorax carbo & 0.0 & 0.0 & 0.0 & 0.0 & 0.0 & 0.0 & 0.0 \\
\hline bw4 & 2060 & Somateria mollissima & 0.0 & 0.0 & 0.0 & 0.0 & 0.0 & 0.0 & 0.0 \\
\hline bw4 & 6110 & Thalasseus sandvicensis & 0.9 & 0.0 & 0.0 & 0.0 & 0.1 & 0.0 & 1.0 \\
\hline bw4 & 6340 & Uria aalge & 8.0 & 3.0 & 7.9 & 2.1 & 2.7 & 0.7 & 24.4 \\
\hline bw6 & 6360 & Alca torda & 0.2 & 7.9 & 9.1 & 34.8 & 0.8 & 0.0 & 52.8 \\
\hline bw6 & 6540 & Fratercula arctica & 0.0 & 0.1 & 0.3 & 1.2 & 0.0 & 0.0 & 1.6 \\
\hline bw6 & 220 & Fulmarus glacialis & 0.9 & 0.5 & 1.4 & 1.2 & 0.8 & 0.6 & 5.4 \\
\hline bw6 & 59 & Gavia sp & 0.0 & 0.0 & 0.2 & 0.0 & 0.0 & 0.0 & 0.2 \\
\hline bw6 & 2130 & Melanitta nigra & 0.0 & 0.0 & 0.0 & 0.0 & 0.0 & 0.0 & 0.0 \\
\hline bw6 & 710 & Morus bassanus & 0.8 & 2.4 & 2.3 & 0.8 & 0.9 & 0.3 & 7.5 \\
\hline bw6 & 720 & Phalacrocorax carbo & 0.0 & 0.0 & 0.0 & 0.0 & 0.0 & 0.0 & 0.0 \\
\hline bw6 & 2060 & Somateria mollissima & 0.0 & 0.0 & 0.0 & 0.0 & 0.0 & 0.0 & 0.0 \\
\hline bw6 & 6110 & Thalasseus sandvicensis & 0.3 & 0.1 & 0.0 & 0.0 & 2.7 & 0.2 & 3.3 \\
\hline bw6 & 6340 & Uria aalge & 5.3 & 30.4 & 34.4 & 54.0 & 48.8 & 2.6 & 175.5 \\
\hline bw7 & 6360 & Alca torda & 0.0 & 2.1 & 4.5 & 10.9 & 0.0 & 0.0 & 17.5 \\
\hline bw7 & 6540 & Fratercula arctica & 0.0 & 0.1 & 0.0 & 0.1 & 0.0 & 0.0 & 0.2 \\
\hline bw7 & 220 & Fulmarus glacialis & 0.0 & 0.1 & 0.2 & 0.5 & 0.0 & 0.1 & 0.9 \\
\hline bw7 & 59 & Gavia $s p$ & 0.0 & 0.0 & 0.2 & 0.0 & 0.0 & 0.0 & 0.2 \\
\hline bw7 & 2130 & Melanitta nigra & 0.0 & 0.0 & 0.0 & 0.0 & 0.0 & 0.0 & 0.0 \\
\hline bw7 & 710 & Morus bassanus & 0.3 & 0.7 & 0.3 & 0.4 & 0.5 & 0.1 & 2.3 \\
\hline bw7 & 720 & Phalacrocorax carbo & 0.0 & 0.0 & 0.0 & 0.0 & 0.0 & 0.0 & 0.0 \\
\hline bw7 & 2060 & Somateria mollissima & 0.0 & 0.0 & 0.0 & 0.0 & 0.0 & 0.0 & 0.0 \\
\hline
\end{tabular}




\begin{tabular}{|c|c|c|c|c|c|c|c|c|c|}
\hline bw7 & 6110 & Thalasseus sandvicensis & 0.1 & 0.0 & 0.0 & 0.0 & 0.5 & 0.0 & 0.6 \\
\hline bw7 & 6340 & Uria aalge & 0.9 & 15.4 & 13.5 & 10.5 & 4.4 & 0.0 & 44.7 \\
\hline bw8 & 6360 & Alca torda & 0.0 & 1.1 & 2.4 & 7.2 & 0.0 & 0.0 & 10.7 \\
\hline bw8 & 6540 & Fratercula arctica & 0.0 & 0.0 & 0.0 & 0.1 & 0.0 & 0.0 & 0.1 \\
\hline bw8 & 220 & Fulmarus glacialis & 0.0 & 0.0 & 0.1 & 0.1 & 0.0 & 0.1 & 0.3 \\
\hline bw8 & 59 & Gavia sp & 0.0 & 0.1 & 0.1 & 0.0 & 0.0 & 0.0 & 0.2 \\
\hline bw8 & 2130 & Melanitta nigra & 0.0 & 0.0 & 0.0 & 0.0 & 0.0 & 0.0 & 0.0 \\
\hline bw8 & 710 & Morus bassanus & 0.1 & 0.3 & 0.0 & 0.1 & 0.2 & 0.0 & 0.7 \\
\hline bw8 & 720 & Phalacrocorax carbo & 0.0 & 0.0 & 0.0 & 0.0 & 0.0 & 0.0 & 0.0 \\
\hline bw8 & 2060 & Somateria mollissima & 0.0 & 0.0 & 0.0 & 0.0 & 0.0 & 0.0 & 0.0 \\
\hline bw8 & 6110 & Thalasseus sandvicensis & 0.0 & 0.0 & 0.0 & 0.0 & 0.1 & 0.0 & 0.1 \\
\hline bw8 & 6340 & Uria aalge & 0.0 & 8.5 & 6.9 & 5.8 & 1.3 & 0.0 & 22.5 \\
\hline 258 & 6360 & Alca torda & 0.2 & 14.7 & 24.3 & 8.1 & 0.5 & 0.1 & 47.9 \\
\hline 258 & 6540 & Fratercula arctica & 0.0 & 0.2 & 0.4 & 0.4 & 0.6 & 0.0 & 1.6 \\
\hline 258 & 220 & Fulmarus glacialis & 1.0 & 0.5 & 0.9 & 0.3 & 0.3 & 0.4 & 3.4 \\
\hline 258 & 59 & Gavia sp & 0.0 & 0.0 & 1.2 & 3.0 & 0.7 & 0.0 & 4.9 \\
\hline 258 & 2130 & Melanitta nigra & 0.0 & 0.0 & 0.0 & 0.0 & 0.0 & 0.0 & 0.0 \\
\hline 258 & 710 & Morus bassanus & 1.3 & 2.7 & 0.5 & 0.2 & 0.0 & 1.2 & 5.9 \\
\hline 258 & 720 & Phalacrocorax carbo & 0.0 & 0.0 & 0.0 & 0.0 & 0.0 & 0.0 & 0.0 \\
\hline 258 & 2060 & Somateria mollissima & 0.0 & 0.0 & 0.0 & 0.0 & 0.0 & 0.0 & 0.0 \\
\hline 258 & 6110 & Thalasseus sandvicensis & 0.1 & 0.0 & 0.0 & 0.0 & 0.4 & 0.0 & 0.5 \\
\hline 258 & 6340 & Uria aalge & 52.9 & 43.4 & 135.9 & 23.7 & 32.7 & 16.0 & 304.6 \\
\hline 2630 & 6360 & Alca torda & 1.0 & 6.2 & 5.7 & 2.8 & 0.7 & 0.0 & 16.4 \\
\hline 2630 & 6540 & Fratercula arctica & 0.0 & 0.2 & 0.2 & 0.1 & 0.5 & 0.0 & 1.0 \\
\hline 2630 & 220 & Fulmarus glacialis & 2.8 & 0.8 & 0.9 & 6.9 & 0.2 & 0.5 & 12.1 \\
\hline 2630 & 59 & Gavia $s p$ & 0.0 & 0.9 & 0.3 & 1.1 & 0.0 & 0.0 & 2.3 \\
\hline 2630 & 2130 & Melanitta nigra & 0.0 & 0.0 & 0.0 & 0.0 & 0.0 & 0.0 & 0.0 \\
\hline 2630 & 710 & Morus bassanus & 0.9 & 2.2 & 0.9 & 0.1 & 0.4 & 0.6 & 5.1 \\
\hline 2630 & 720 & Phalacrocorax carbo & 0.0 & 0.0 & 0.0 & 0.0 & 0.0 & 0.0 & 0.0 \\
\hline 2630 & 2060 & Somateria mollissima & 0.0 & 0.0 & 0.0 & 0.0 & 0.0 & 0.0 & 0.0 \\
\hline 2630 & 6110 & Thalasseus sandvicensis & 1.4 & 0.0 & 0.0 & 0.0 & 0.7 & 0.0 & 2.1 \\
\hline 2630 & 6340 & Uria aalge & 56.0 & 10.2 & 24.8 & 6.4 & 7.5 & 13.4 & 118.3 \\
\hline 270 & 6360 & Alca torda & 0.0 & 6.4 & 13.2 & 17.9 & 0.4 & 0.0 & 37.9 \\
\hline 270 & 6540 & Fratercula arctica & 0.0 & 0.1 & 0.1 & 0.2 & 0.0 & 0.0 & 0.4 \\
\hline 270 & 220 & Fulmarus glacialis & 0.1 & 0.4 & 0.6 & 0.1 & 0.1 & 0.1 & 1.4 \\
\hline 270 & 59 & Gavia sp & 0.0 & 0.0 & 0.0 & 0.2 & 0.6 & 0.0 & 0.8 \\
\hline 270 & 2130 & Melanitta nigra & 0.0 & 0.0 & 0.0 & 0.0 & 0.0 & 0.0 & 0.0 \\
\hline 270 & 710 & Morus bassanus & 0.4 & 1.4 & 0.9 & 0.2 & 0.4 & 0.2 & 3.5 \\
\hline 270 & 720 & Phalacrocorax carbo & 0.0 & 0.0 & 0.0 & 0.0 & 0.0 & 0.0 & 0.0 \\
\hline 270 & 2060 & Somateria mollissima & 0.0 & 0.0 & 0.0 & 0.0 & 0.0 & 0.0 & 0.0 \\
\hline 270 & 6110 & Thalasseus sandvicensis & 0.3 & 0.0 & 0.0 & 0.0 & 0.6 & 0.2 & 1.1 \\
\hline 270 & 6340 & Uria aalge & 1.6 & 25.3 & 34.0 & 21.4 & 28.8 & 1.1 & 112.2 \\
\hline 272 & 6360 & Alca torda & 0.1 & 4.5 & 10.6 & 7.3 & 0.4 & 0.0 & 22.9 \\
\hline 272 & 6540 & Fratercula arctica & 0.0 & 0.0 & 0.1 & 0.2 & 0.0 & 0.0 & 0.3 \\
\hline 272 & 220 & Fulmarus glacialis & 0.4 & 0.4 & 0.5 & 0.2 & 0.3 & 0.2 & 2.0 \\
\hline 272 & 59 & Gavia sp & 0.0 & 0.0 & 0.0 & 2.9 & 0.6 & 0.0 & 3.5 \\
\hline 272 & 2130 & Melanitta nigra & 0.0 & 0.0 & 0.0 & 0.0 & 0.0 & 0.0 & 0.0 \\
\hline 272 & 710 & Morus bassanus & 0.4 & 1.5 & 0.9 & 0.1 & 0.2 & 0.1 & 3.2 \\
\hline 272 & 720 & Phalacrocorax carbo & 0.0 & 0.0 & 0.0 & 0.0 & 0.0 & 0.0 & 0.0 \\
\hline 272 & 2060 & Somateria mollissima & 0.0 & 0.0 & 0.0 & 0.0 & 0.0 & 0.0 & 0.0 \\
\hline 272 & 6110 & Thalasseus sandvicensis & 0.0 & 0.0 & 0.0 & 0.0 & 0.0 & 0.0 & 0.0 \\
\hline 272 & 6340 & Uria aalge & 9.4 & 17.0 & 32.2 & 11.0 & 20.0 & 1.7 & 91.3 \\
\hline 274 & 6360 & Alca torda & 0.2 & 44.4 & 10.6 & 13.1 & 2.7 & 0.0 & 71.0 \\
\hline 274 & 6540 & Fratercula arctica & 0.0 & 0.1 & 0.1 & 0.0 & 0.0 & 0.0 & 0.2 \\
\hline 274 & 220 & Fulmarus glacialis & 0.1 & 0.3 & 0.3 & 0.8 & 0.2 & 0.4 & 2.1 \\
\hline 274 & 59 & Gavia sp & 0.0 & 0.0 & 0.3 & 0.5 & 1.5 & 0.0 & 2.3 \\
\hline 274 & 2130 & Melanitta nigra & 0.0 & 0.0 & 0.0 & 0.0 & 0.0 & 0.0 & 0.0 \\
\hline 274 & 710 & Morus bassanus & 1.6 & 1.9 & 0.7 & 1.4 & 0.9 & 0.7 & 7.2 \\
\hline 274 & 720 & Phalacrocorax carbo & 0.0 & 0.0 & 0.0 & 0.0 & 0.0 & 0.0 & 0.0 \\
\hline 274 & 2060 & Somateria mollissima & 0.0 & 0.0 & 0.0 & 0.0 & 0.0 & 0.0 & 0.0 \\
\hline 274 & 6110 & Thalasseus sandvicensis & 1.4 & 0.1 & 0.0 & 0.0 & 1.3 & 0.2 & 3.0 \\
\hline 274 & 6340 & Uria aalge & 27.5 & 42.2 & 45.8 & 31.9 & 27.8 & 6.0 & 181.2 \\
\hline
\end{tabular}


Wageningen Marine Research

T +31 (0)31748 7000

E: marine-research@wur.nl www.wur.eu/marine-research

Visitors' address

- Ankerpark 271781 AG Den Helder

- Korringaweg 7, 4401 NT Yerseke

- Haringkade 1, 1976 CP IJmuiden
With knowledge, independent scientific research and advice, Wageningen Marine Research substantially contributes to more sustainable and more careful management, use and protection of natural riches in marine, coastal and freshwater areas.
Wageningen Marine Research is part of Wageningen University \& Research. Wageningen University \& Research is the collaboration between Wageningen University and the Wageningen Research Foundation and its mission is: 'To explore the potential for improving the quality of life' 
Table 1: Number of casualties from habitat loss per OWP, species

and season. International data (batch $=$ 'INT')

\begin{tabular}{|c|c|c|c|c|c|c|c|c|c|c|}
\hline CountryName & UniekID & EUring & species & Aug + Sep & Okt + Nov & Dec + Jan & Feb + Mar & Apr + May & Jun + Jul & Total \\
\hline Belgium & BE01 & 6360 & Alca torda & 0.0 & 0.2 & 0.2 & 0.1 & 0.0 & 0.0 & 0.6 \\
\hline Belgium & BE01 & 6540 & Fratercula arctica & 0.0 & 0.0 & 0.0 & 0.0 & 0.0 & 0.0 & 0.0 \\
\hline Belgium & BE01 & 220 & Fulmarus glacialis & 0.0 & 0.0 & 0.0 & 0.0 & 0.0 & 0.0 & 0.0 \\
\hline Belgium & BE01 & 59 & Gavia sp & 0.0 & 0.0 & 0.0 & 0.0 & 0.0 & 0.0 & 0.0 \\
\hline Belgium & BE01 & 2130 & Melanitta nigra & 0.0 & 0.0 & 0.0 & 0.0 & 0.0 & 0.0 & 0.0 \\
\hline Belgium & BE01 & 710 & Morus bassanus & 0.0 & 0.0 & 0.0 & 0.0 & 0.0 & 0.0 & 0.1 \\
\hline Belgium & BE01 & 720 & Phalacrocorax carbo & 0.0 & 0.0 & 0.0 & 0.0 & 0.0 & 0.0 & 0.0 \\
\hline Belgium & BE01 & 2060 & Somoteria mollissima & 0.0 & 0.0 & 0.0 & 0.0 & 0.0 & 0.0 & 0.0 \\
\hline Belgium & BE01 & 6110 & Thalasseus sandvicensis & 0.0 & 0.0 & 0.0 & 0.0 & 0.1 & 0.0 & 0.1 \\
\hline Belgium & BE01 & 6340 & Uria aalge & 0.0 & 0.5 & 0.5 & 0.1 & 0.0 & 0.0 & 1.1 \\
\hline Belgium & $\mathrm{BE} 02$ & 6360 & Alca torda & 0.0 & 1.4 & 0.4 & 1.1 & 0.0 & 0.0 & 2.9 \\
\hline Belgium & BE02 & 6540 & Fratercula arctica & 0.0 & 0.0 & 0.0 & 0.0 & 0.0 & 0.0 & 0.0 \\
\hline Belgium & BE02 & 220 & Fulmarus glacialis & 0.0 & 0.0 & 0.0 & 0.0 & 0.0 & 0.0 & 0.1 \\
\hline Belgium & $\mathrm{BE} 02$ & 59 & Gavia sp & 0.0 & 0.0 & 0.0 & 0.0 & 0.0 & 0.0 & 0.1 \\
\hline Belgium & BE02 & 2130 & Melanitta nigra & 0.0 & 0.0 & 0.0 & 0.0 & 0.0 & 0.0 & 0.0 \\
\hline Belgium & BE02 & 710 & Morus bassanus & 0.1 & 0.2 & 0.1 & 0.1 & 0.1 & 0.0 & 0.6 \\
\hline Belgium & BE02 & 720 & Phalacrocorax carbo & 0.0 & 0.0 & 0.0 & 0.0 & 0.0 & 0.0 & 0.0 \\
\hline Belgium & BE02 & 2060 & Somoteria mollissima & 0.0 & 0.0 & 0.0 & 0.0 & 0.0 & 0.0 & 0.0 \\
\hline Belgium & BE02 & 6110 & Thalasseus sandvicensis & 0.0 & 0.0 & 0.0 & 0.0 & 0.1 & 0.2 & 0.3 \\
\hline Belgium & BE02 & 6340 & Uria aalge & 0.0 & 2.6 & 2.0 & 1.8 & 0.0 & 0.0 & 6.4 \\
\hline Belgium & BE03 & 6360 & Alca torda & 0.0 & 0.2 & 0.5 & 4.1 & 0.0 & 0.0 & 4.9 \\
\hline Belgium & BE03 & 6540 & Fratercula arctica & 0.0 & 0.0 & 0.0 & 0.0 & 0.0 & 0.0 & 0.0 \\
\hline Belgium & BE03 & 220 & Fulmarus glacialis & 0.0 & 0.1 & 0.1 & 0.0 & 0.0 & 0.0 & 0.2 \\
\hline Belgium & BE03 & 59 & Gavia sp & 0.0 & 0.0 & 0.0 & 0.0 & 0.0 & 0.0 & 0.0 \\
\hline Belgium & $\mathrm{BE} 03$ & 2130 & Melanitta nigra & 0.0 & 0.0 & 0.0 & 0.0 & 0.0 & 0.0 & 0.0 \\
\hline Belgium & BE03 & 710 & Morus bassanus & 0.1 & 0.2 & 0.2 & 0.2 & 0.0 & 0.0 & 0.7 \\
\hline Belgium & BE03 & 720 & Phalacrocorax carbo & 0.0 & 0.0 & 0.0 & 0.0 & 0.0 & 0.0 & 0.0 \\
\hline Belgium & BE03 & 2060 & Somoteria mollissima & 0.0 & 0.0 & 0.0 & 0.0 & 0.0 & 0.0 & 0.0 \\
\hline Belgium & BE03 & 6110 & Thalasseus sandvicensis & 0.0 & 0.0 & 0.0 & 0.0 & 0.0 & 0.0 & 0.0 \\
\hline Belgium & BE03 & 6340 & Uria aalge & 0.0 & 0.2 & 2.1 & 4.2 & 0.0 & 0.0 & 6.4 \\
\hline Belgium & BE04 & 6360 & Alca torda & 0.1 & 2.6 & 2.5 & 0.8 & 0.0 & 0.0 & 6.0 \\
\hline Belgium & BE04 & 6540 & Fratercula arctica & 0.0 & 0.0 & 0.0 & 0.0 & 0.0 & 0.0 & 0.0 \\
\hline Belgium & BE04 & 220 & Fulmarus glacialis & 0.0 & 0.0 & 0.0 & 0.0 & 0.0 & 0.0 & 0.1 \\
\hline Belgium & BE04 & 59 & Gavia sp & 0.0 & 1.0 & 2.0 & 0.3 & 0.0 & 0.0 & 3.3 \\
\hline Belgium & BE04 & 2130 & Melanitta nigra & 0.0 & 0.0 & 0.3 & 0.1 & 0.1 & 0.0 & 0.5 \\
\hline Belgium & BE04 & 710 & Morus bassanus & 0.1 & 0.2 & 0.1 & 0.1 & 0.1 & 0.2 & 0.9 \\
\hline Belgium & BE04 & 720 & Phalacrocorax carbo & 0.0 & 0.0 & 0.0 & 0.0 & 0.0 & 0.0 & 0.0 \\
\hline Belgium & BE04 & 2060 & Somoteria mollissima & 0.0 & 0.0 & 0.0 & 0.0 & 0.0 & 0.0 & 0.0 \\
\hline Belgium & BE04 & 6110 & Thalasseus sandvicensis & 0.2 & 0.0 & 0.0 & 0.0 & 0.2 & 0.4 & 0.9 \\
\hline Belgium & BE04 & 6340 & Uria aalge & 0.0 & 4.4 & 5.6 & 2.5 & 0.0 & 0.0 & 12.6 \\
\hline Belgium & BE05 & 6360 & Alca torda & 0.0 & 2.0 & 1.0 & 1.1 & 0.0 & 0.0 & 4.1 \\
\hline Belgium & BE05 & 6540 & Fratercula arctica & 0.0 & 0.0 & 0.0 & 0.0 & 0.0 & 0.0 & 0.0 \\
\hline Belgium & BE05 & 220 & Fulmarus glacialis & 0.0 & 0.0 & 0.0 & 0.0 & 0.0 & 0.0 & 0.1 \\
\hline Belgium & BE05 & 59 & Gavia sp & 0.0 & 0.0 & 0.1 & 0.1 & 0.0 & 0.0 & 0.2 \\
\hline Belgium & BE05 & 2130 & Melanitta nigra & 0.0 & 0.0 & 0.0 & 0.0 & 0.0 & 0.0 & 0.0 \\
\hline Belgium & BE05 & 710 & Morus bassanus & 0.1 & 0.2 & 0.1 & 0.1 & 0.1 & 0.1 & 0.7 \\
\hline Belgium & BE05 & 720 & Phalacrocorax carbo & 0.0 & 0.0 & 0.0 & 0.0 & 0.0 & 0.0 & 0.0 \\
\hline Belgium & BE05 & 2060 & Somoteria mollissima & 0.0 & 0.0 & 0.0 & 0.0 & 0.0 & 0.0 & 0.0 \\
\hline Belgium & BE05 & 6110 & Thalasseus sandvicensis & 0.0 & 0.0 & 0.0 & 0.0 & 0.2 & 0.4 & 0.6 \\
\hline Belgium & BE05 & 6340 & Uria aalge & 0.0 & 4.1 & 3.7 & 2.2 & 0.0 & 0.0 & 10.1 \\
\hline Belgium & BE06 & 6360 & Alca torda & 0.0 & 1.1 & 0.5 & 3.5 & 0.0 & 0.0 & 5.1 \\
\hline Belgium & BE06 & 6540 & Fratercula arctica & 0.0 & 0.0 & 0.0 & 0.0 & 0.0 & 0.0 & 0.0 \\
\hline Belgium & BE06 & 220 & Fulmarus glacialis & 0.0 & 0.0 & 0.0 & 0.0 & 0.0 & 0.0 & 0.2 \\
\hline Belgium & BE06 & 59 & Gavia sp & 0.0 & 0.0 & 0.1 & 0.0 & 0.0 & 0.0 & 0.1 \\
\hline
\end{tabular}




\begin{tabular}{|c|c|c|c|c|c|c|c|c|c|c|}
\hline CountryName & UniekID & EUring & species & Aug + Sep & Okt + Nov & Dec + Jan & Feb + Mar & Apr + May & Jun + Jul & Total \\
\hline Belgium & BE06 & 2130 & Melanitta nigra & 0.0 & 0.0 & 0.0 & 0.0 & 0.0 & 0.0 & 0.0 \\
\hline Belgium & BE06 & 710 & Morus bassanus & 0.1 & 0.2 & 0.2 & 0.2 & 0.1 & 0.0 & 0.8 \\
\hline Belgium & BE06 & 720 & Phalacrocorax carbo & 0.0 & 0.0 & 0.0 & 0.0 & 0.0 & 0.0 & 0.0 \\
\hline Belgium & BE06 & 2060 & Somoteria mollissima & 0.0 & 0.0 & 0.0 & 0.0 & 0.0 & 0.0 & 0.0 \\
\hline Belgium & BE06 & 6110 & Thalasseus sandvicensis & 0.0 & 0.0 & 0.0 & 0.0 & 0.1 & 0.0 & 0.1 \\
\hline Belgium & BE06 & 6340 & Uria aalge & 0.0 & 2.1 & 2.4 & 2.8 & 0.0 & 0.0 & 7.4 \\
\hline Belgium & BE07 & 6360 & Alca torda & 0.0 & 0.4 & 0.4 & 2.0 & 0.0 & 0.0 & 2.8 \\
\hline Belgium & BE07 & 6540 & Fratercula arctica & 0.0 & 0.0 & 0.0 & 0.0 & 0.0 & 0.0 & 0.0 \\
\hline Belgium & BE07 & 220 & Fulmarus glacialis & 0.0 & 0.2 & 0.1 & 0.1 & 0.0 & 0.0 & 0.4 \\
\hline Belgium & BE07 & 59 & Gavia sp & 0.0 & 0.0 & 0.0 & 0.0 & 0.0 & 0.0 & 0.0 \\
\hline Belgium & BE07 & 2130 & Melanitta nigra & 0.0 & 0.0 & 0.0 & 0.0 & 0.0 & 0.0 & 0.0 \\
\hline Belgium & BE07 & 710 & Morus bassanus & 0.0 & 0.2 & 0.1 & 0.3 & 0.0 & 0.1 & 0.6 \\
\hline Belgium & BE07 & 720 & Phalacrocorax carbo & 0.0 & 0.0 & 0.0 & 0.0 & 0.0 & 0.0 & 0.0 \\
\hline Belgium & BE07 & 2060 & Somoteria mollissima & 0.0 & 0.0 & 0.0 & 0.0 & 0.0 & 0.0 & 0.0 \\
\hline Belgium & BE07 & 6110 & Thalasseus sandvicensis & 0.0 & 0.0 & 0.0 & 0.0 & 0.0 & 0.0 & 0.0 \\
\hline Belgium & BE07 & 6340 & Uria aalge & 0.0 & 0.4 & 2.1 & 4.5 & 0.0 & 0.0 & 7.1 \\
\hline Belgium & BE08 & 6360 & Alca torda & 0.0 & 1.0 & 0.9 & 4.9 & 0.0 & 0.0 & 6.8 \\
\hline Belgium & BE08 & 6540 & Fratercula arctica & 0.0 & 0.0 & 0.0 & 0.0 & 0.0 & 0.0 & 0.0 \\
\hline Belgium & BE08 & 220 & Fulmarus glacialis & 0.0 & 0.1 & 0.1 & 0.1 & 0.0 & 0.0 & 0.4 \\
\hline Belgium & BE08 & 59 & Gavia sp & 0.0 & 0.0 & 0.0 & 0.1 & 0.0 & 0.0 & 0.1 \\
\hline Belgium & BE08 & 2130 & Melanitta nigra & 0.0 & 0.0 & 0.0 & 0.0 & 0.0 & 0.0 & 0.0 \\
\hline Belgium & BE08 & 710 & Morus bassanus & 0.1 & 0.3 & 0.2 & 0.4 & 0.1 & 0.0 & 1.1 \\
\hline Belgium & BE08 & 720 & Phalacrocorax carbo & 0.0 & 0.0 & 0.0 & 0.0 & 0.0 & 0.0 & 0.0 \\
\hline Belgium & BE08 & 2060 & Somoteria mollissima & 0.0 & 0.0 & 0.0 & 0.0 & 0.0 & 0.0 & 0.0 \\
\hline Belgium & BE08 & 6110 & Thalasseus sandvicensis & 0.0 & 0.0 & 0.0 & 0.0 & 0.1 & 0.0 & 0.1 \\
\hline Belgium & BE08 & 6340 & Uria aalge & 0.0 & 0.7 & 3.7 & 5.5 & 0.0 & 0.0 & 9.9 \\
\hline Belgium & BE09 & 6360 & Alca torda & 0.0 & 1.7 & 1.1 & 1.1 & 0.0 & 0.0 & 3.9 \\
\hline Belgium & BE09 & 6540 & Fratercula arctica & 0.0 & 0.0 & 0.0 & 0.0 & 0.0 & 0.0 & 0.0 \\
\hline Belgium & BE09 & 220 & Fulmarus glacialis & 0.0 & 0.0 & 0.0 & 0.0 & 0.0 & 0.0 & 0.1 \\
\hline Belgium & BE09 & 59 & Gavia sp & 0.0 & 0.0 & 0.0 & 0.1 & 0.0 & 0.0 & 0.1 \\
\hline Belgium & BE09 & 2130 & Melanitta nigra & 0.0 & 0.0 & 0.1 & 0.0 & 0.0 & 0.0 & 0.1 \\
\hline Belgium & BE09 & 710 & Morus bassanus & 0.1 & 0.1 & 0.0 & 0.1 & 0.0 & 0.1 & 0.4 \\
\hline Belgium & BE09 & 720 & Phalacrocorax carbo & 0.0 & 0.0 & 0.0 & 0.0 & 0.0 & 0.0 & 0.0 \\
\hline Belgium & BE09 & 2060 & Somoteria mollissima & 0.0 & 0.0 & 0.0 & 0.0 & 0.0 & 0.0 & 0.0 \\
\hline Belgium & BE09 & 6110 & Thalasseus sandvicensis & 0.0 & 0.0 & 0.0 & 0.0 & 0.2 & 0.3 & 0.5 \\
\hline Belgium & BE09 & 6340 & Uria aalge & 0.0 & 3.1 & 3.3 & 1.2 & 0.0 & 0.0 & 7.5 \\
\hline Belgium & BE10 & 6360 & Alca torda & 0.0 & 0.9 & 0.9 & 0.9 & 0.0 & 0.0 & 2.7 \\
\hline Belgium & BE10 & 6540 & Fratercula arctica & 0.0 & 0.0 & 0.0 & 0.0 & 0.0 & 0.0 & 0.0 \\
\hline Belgium & BE10 & 220 & Fulmarus glacialis & 0.0 & 0.0 & 0.0 & 0.0 & 0.0 & 0.0 & 0.0 \\
\hline Belgium & BE10 & 59 & Gavia sp & 0.0 & 0.0 & 0.1 & 0.0 & 0.0 & 0.0 & 0.1 \\
\hline Belgium & BE10 & 2130 & Melanitta nigra & 0.0 & 0.0 & 0.0 & 0.0 & 0.0 & 0.0 & 0.0 \\
\hline Belgium & BE10 & 710 & Morus bassanus & 0.1 & 0.1 & 0.0 & 0.0 & 0.0 & 0.0 & 0.3 \\
\hline Belgium & BE10 & 720 & Phalacrocorax carbo & 0.0 & 0.0 & 0.0 & 0.0 & 0.0 & 0.0 & 0.0 \\
\hline Belgium & BE10 & 2060 & Somoteria mollissima & 0.0 & 0.0 & 0.0 & 0.0 & 0.0 & 0.0 & 0.0 \\
\hline Belgium & BE10 & 6110 & Thalasseus sandvicensis & 0.0 & 0.0 & 0.0 & 0.0 & 0.1 & 0.1 & 0.2 \\
\hline Belgium & BE10 & 6340 & Uria aalge & 0.0 & 2.4 & 2.0 & 0.8 & 0.0 & 0.0 & 5.2 \\
\hline Belgium & BE12 & 6360 & Alca torda & 0.0 & 0.5 & 0.5 & 1.5 & 0.0 & 0.0 & 2.4 \\
\hline Belgium & BE12 & 6540 & Fratercula arctica & 0.0 & 0.0 & 0.0 & 0.0 & 0.0 & 0.0 & 0.0 \\
\hline Belgium & BE12 & 220 & Fulmarus glacialis & 0.0 & 0.1 & 0.1 & 0.1 & 0.0 & 0.0 & 0.3 \\
\hline Belgium & BE12 & 59 & Gavia sp & 0.0 & 0.0 & 0.0 & 0.1 & 0.0 & 0.0 & 0.1 \\
\hline Belgium & BE12 & 2130 & Melanitta nigra & 0.0 & 0.0 & 0.0 & 0.0 & 0.0 & 0.0 & 0.0 \\
\hline Belgium & BE12 & 710 & Morus bassanus & 0.0 & 0.1 & 0.1 & 0.2 & 0.0 & 0.0 & 0.5 \\
\hline Belgium & BE12 & 720 & Phalacrocorax carbo & 0.0 & 0.0 & 0.0 & 0.0 & 0.0 & 0.0 & 0.0 \\
\hline Belgium & BE12 & 2060 & Somoteria mollissima & 0.0 & 0.0 & 0.0 & 0.0 & 0.0 & 0.0 & 0.0 \\
\hline Belgium & BE12 & 6110 & Thalasseus sandvicensis & 0.0 & 0.0 & 0.0 & 0.0 & 0.0 & 0.0 & 0.0 \\
\hline Belgium & BE12 & 6340 & Uria aalge & 0.0 & 0.2 & 2.1 & 3.2 & 0.0 & 0.0 & 5.6 \\
\hline
\end{tabular}




\begin{tabular}{|c|c|c|c|c|c|c|c|c|c|c|}
\hline CountryName & UniekID & EUring & species & Aug + Sep & Okt + Nov & Dec + Jan & Feb + Mar & Apr + May & Jun + Jul & Total \\
\hline Belgium & BE14 & 6360 & Alca torda & 0.0 & 0.4 & 3.5 & 3.8 & 0.5 & 0.0 & 8.2 \\
\hline Belgium & BE14 & 6540 & Fratercula arctica & 0.0 & 0.0 & 0.0 & 0.0 & 0.0 & 0.0 & 0.0 \\
\hline Belgium & BE14 & 220 & Fulmarus glacialis & 0.1 & 0.7 & 0.2 & 0.2 & 0.1 & 0.1 & 1.5 \\
\hline Belgium & BE14 & 59 & Gavia sp & 0.0 & 0.5 & 0.0 & 0.2 & 0.0 & 0.0 & 0.8 \\
\hline Belgium & BE14 & 2130 & Melanitta nigra & 0.0 & 0.0 & 0.0 & 0.0 & 0.0 & 0.0 & 0.0 \\
\hline Belgium & BE14 & 710 & Morus bassanus & 0.1 & 0.7 & 0.3 & 0.5 & 0.1 & 0.1 & 2.0 \\
\hline Belgium & BE14 & 720 & Phalacrocorax carbo & 0.0 & 0.0 & 0.0 & 0.0 & 0.0 & 0.0 & 0.0 \\
\hline Belgium & BE14 & 2060 & Somoteria mollissima & 0.0 & 0.0 & 0.0 & 0.0 & 0.0 & 0.0 & 0.0 \\
\hline Belgium & BE14 & 6110 & Thalasseus sandvicensis & 0.0 & 0.0 & 0.0 & 0.0 & 0.3 & 0.0 & 0.3 \\
\hline Belgium & BE14 & 6340 & Uria aalge & 0.1 & 2.8 & 15.4 & 9.3 & 1.1 & 0.0 & 28.7 \\
\hline Belgium & BE15 & 6360 & Alca torda & 0.0 & 2.2 & 9.5 & 8.1 & 0.3 & 0.0 & 20.2 \\
\hline Belgium & BE15 & 6540 & Fratercula arctica & 0.0 & 0.0 & 0.0 & 0.0 & 0.0 & 0.0 & 0.1 \\
\hline Belgium & BE15 & 220 & Fulmarus glacialis & 0.1 & 0.4 & 0.3 & 0.3 & 0.2 & 0.2 & 1.4 \\
\hline Belgium & BE15 & 59 & Gavia sp & 0.0 & 0.0 & 0.2 & 0.5 & 0.3 & 0.0 & 1.0 \\
\hline Belgium & BE15 & 2130 & Melanitta nigra & 0.0 & 0.0 & 0.0 & 0.4 & 0.0 & 0.0 & 0.4 \\
\hline Belgium & BE15 & 710 & Morus bassanus & 0.3 & 1.2 & 0.6 & 0.9 & 0.4 & 0.3 & 3.8 \\
\hline Belgium & BE15 & 720 & Phalacrocorax carbo & 0.0 & 0.0 & 0.0 & 0.0 & 0.0 & 0.0 & 0.0 \\
\hline Belgium & BE15 & 2060 & Somoteria mollissima & 0.0 & 0.0 & 0.0 & 0.0 & 0.0 & 0.0 & 0.0 \\
\hline Belgium & BE15 & 6110 & Thalasseus sandvicensis & 0.2 & 0.0 & 0.0 & 0.1 & 0.2 & 0.2 & 0.8 \\
\hline Belgium & BE15 & 6340 & Uria aalge & 0.0 & 5.1 & 21.9 & 22.1 & 2.0 & 0.0 & 51.1 \\
\hline Denmark & DK03 & 6360 & Alca torda & 0.0 & 0.0 & 0.0 & 0.0 & 0.0 & 0.0 & 0.0 \\
\hline Denmark & DK03 & 6540 & Fratercula arctica & 0.0 & 0.0 & 0.0 & 0.0 & 0.0 & 0.0 & 0.0 \\
\hline Denmark & DK03 & 220 & Fulmarus glacialis & 0.1 & 0.0 & 0.0 & 0.0 & 0.0 & 0.0 & 0.1 \\
\hline Denmark & DK03 & 59 & Gavia sp & 0.0 & 0.1 & 1.6 & 5.7 & 7.2 & 0.0 & 14.5 \\
\hline Denmark & DK03 & 2130 & Melanitta nigra & 0.0 & 0.0 & 0.2 & 0.0 & 0.0 & 0.1 & 0.3 \\
\hline Denmark & DK03 & 710 & Morus bassanus & 0.0 & 0.0 & 0.0 & 0.0 & 0.0 & 0.0 & 0.0 \\
\hline Denmark & DK03 & 720 & Phalacrocorax carbo & 0.0 & 0.0 & 0.0 & 0.0 & 0.0 & 0.0 & 0.0 \\
\hline Denmark & DK03 & 2060 & Somoteria mollissima & 0.0 & 0.0 & 0.0 & 0.0 & 0.0 & 0.0 & 0.0 \\
\hline Denmark & DK03 & 6110 & Thalasseus sandvicensis & 0.0 & 0.0 & 0.0 & 0.0 & 0.0 & 0.0 & 0.0 \\
\hline Denmark & DK03 & 6340 & Uria aalge & 3.7 & 0.7 & 0.3 & 0.2 & 0.0 & 0.0 & 4.8 \\
\hline Denmark & DK10 & 6360 & Alca torda & 0.0 & 0.0 & 0.4 & 0.0 & 0.0 & 0.0 & 0.4 \\
\hline Denmark & DK10 & 6540 & Fratercula arctica & 0.0 & 0.0 & 0.0 & 0.0 & 0.0 & 0.0 & 0.0 \\
\hline Denmark & DK10 & 220 & Fulmarus glacialis & 0.2 & 0.0 & 0.0 & 0.0 & 0.2 & 0.2 & 0.6 \\
\hline Denmark & DK10 & 59 & Gavia sp & 0.0 & 0.0 & 15.0 & 5.2 & 4.1 & 0.0 & 24.3 \\
\hline Denmark & DK10 & 2130 & Melanitta nigra & 0.0 & 0.0 & 0.4 & 0.0 & 0.0 & 0.0 & 0.4 \\
\hline Denmark & DK10 & 710 & Morus bassanus & 0.0 & 0.0 & 0.0 & 0.0 & 0.0 & 0.1 & 0.2 \\
\hline Denmark & DK10 & 720 & Phalacrocorax carbo & 0.0 & 0.0 & 0.0 & 0.0 & 0.0 & 0.0 & 0.0 \\
\hline Denmark & DK10 & 2060 & Somoteria mollissima & 0.0 & 0.0 & 0.1 & 0.0 & 0.0 & 0.0 & 0.1 \\
\hline Denmark & DK10 & 6110 & Thalasseus sandvicensis & 0.0 & 0.0 & 0.0 & 0.0 & 0.0 & 0.0 & 0.0 \\
\hline Denmark & DK10 & 6340 & Uria aalge & 2.0 & 0.4 & 1.8 & 0.5 & 0.3 & 0.3 & 5.3 \\
\hline Denmark & DK19 & 6360 & Alca torda & 0.0 & 0.3 & 0.0 & 0.1 & 0.0 & 0.0 & 0.5 \\
\hline Denmark & DK19 & 6540 & Fratercula arctica & 0.0 & 0.0 & 0.0 & 0.0 & 0.0 & 0.0 & 0.0 \\
\hline Denmark & DK19 & 220 & Fulmarus glacialis & 0.4 & 0.1 & 0.0 & 0.0 & 0.1 & 0.5 & 1.0 \\
\hline Denmark & DK19 & 59 & Gavia sp & 0.0 & 0.0 & 15.1 & 11.0 & 7.5 & 0.0 & 33.6 \\
\hline Denmark & DK19 & 2130 & Melanitta nigra & 0.0 & 0.0 & 0.0 & 0.0 & 0.0 & 0.0 & 0.0 \\
\hline Denmark & DK19 & 710 & Morus bassanus & 0.2 & 0.0 & 0.0 & 0.0 & 0.0 & 0.4 & 0.6 \\
\hline Denmark & DK19 & 720 & Phalacrocorax carbo & 0.0 & 0.0 & 0.0 & 0.0 & 0.0 & 0.0 & 0.0 \\
\hline Denmark & DK19 & 2060 & Somoteria mollissima & 0.0 & 0.0 & 0.0 & 0.0 & 0.0 & 0.0 & 0.0 \\
\hline Denmark & DK19 & 6110 & Thalasseus sandvicensis & 0.0 & 0.0 & 0.0 & 0.0 & 0.1 & 0.0 & 0.1 \\
\hline Denmark & DK19 & 6340 & Uria aalge & 3.8 & 1.3 & 3.4 & 1.5 & 0.4 & 1.0 & 11.3 \\
\hline Denmark & DK22 & 6360 & Alca torda & 0.0 & 0.4 & 0.7 & 0.6 & 0.1 & 0.0 & 1.7 \\
\hline Denmark & DK22 & 6540 & Fratercula arctica & 0.0 & 0.0 & 0.0 & 0.0 & 0.0 & 0.0 & 0.0 \\
\hline Denmark & DK22 & 220 & Fulmarus glacialis & 0.1 & 0.0 & 0.1 & 0.0 & 0.1 & 0.1 & 0.4 \\
\hline Denmark & DK22 & 59 & Gavia sp & 0.0 & 0.0 & 0.4 & 0.0 & 0.2 & 0.0 & 0.7 \\
\hline Denmark & DK22 & 2130 & Melanitta nigra & 0.0 & 0.0 & 0.0 & 5.7 & 0.0 & 0.0 & 5.7 \\
\hline Denmark & DK22 & 710 & Morus bassanus & 0.1 & 0.7 & 0.0 & 0.0 & 0.0 & 0.0 & 0.7 \\
\hline
\end{tabular}




\begin{tabular}{|c|c|c|c|c|c|c|c|c|c|c|}
\hline CountryName & UniekID & EUring & species & Aug + Sep & Okt + Nov & Dec + Jan & Feb + Mar & Apr + May & Jun + Jul & Total \\
\hline Denmark & DK22 & 720 & Phalacrocorax carbo & 0.0 & 0.0 & 0.0 & 0.0 & 0.0 & 0.0 & 0.0 \\
\hline Denmark & DK22 & 2060 & Somoteria mollissima & 0.0 & 0.0 & 0.0 & 0.0 & 0.0 & 0.0 & 0.0 \\
\hline Denmark & DK22 & 6110 & Thalasseus sandvicensis & 0.0 & 0.0 & 0.0 & 0.0 & 0.0 & 0.0 & 0.0 \\
\hline Denmark & DK22 & 6340 & Uria aalge & 0.4 & 0.1 & 2.5 & 0.5 & 0.0 & 0.4 & 3.9 \\
\hline Denmark & DK48 & 6360 & Alca torda & 0.0 & 0.2 & 0.2 & 0.0 & 0.0 & 0.0 & 0.4 \\
\hline Denmark & DK48 & 6540 & Fratercula arctica & 0.0 & 0.0 & 0.0 & 0.0 & 0.0 & 0.0 & 0.0 \\
\hline Denmark & DK48 & 220 & Fulmarus glacialis & 0.0 & 0.0 & 0.0 & 0.0 & 0.0 & 0.4 & 0.5 \\
\hline Denmark & DK48 & 59 & Gavia sp & 0.0 & 0.0 & 0.2 & 0.1 & 0.6 & 0.0 & 0.9 \\
\hline Denmark & DK48 & 2130 & Melanitta nigra & 0.0 & 0.0 & 0.0 & 0.9 & 1.9 & 0.0 & 2.8 \\
\hline Denmark & DK48 & 710 & Morus bassanus & 0.0 & 0.2 & 0.0 & 0.0 & 0.0 & 0.0 & 0.2 \\
\hline Denmark & DK48 & 720 & Phalacrocorax carbo & 0.0 & 0.0 & 0.0 & 0.0 & 0.0 & 0.0 & 0.0 \\
\hline Denmark & DK48 & 2060 & Somoteria mollissima & 0.0 & 0.0 & 0.0 & 0.0 & 0.0 & 0.0 & 0.0 \\
\hline Denmark & DK48 & 6110 & Thalasseus sandvicensis & 0.0 & 0.0 & 0.0 & 0.0 & 0.0 & 0.0 & 0.0 \\
\hline Denmark & DK48 & 6340 & Uria aalge & 0.2 & 0.1 & 0.3 & 0.0 & 0.0 & 0.3 & 0.9 \\
\hline Germany & DE01 & 6360 & Alca torda & 0.0 & 0.1 & 0.0 & 0.0 & 0.0 & 0.0 & 0.2 \\
\hline Germany & DE01 & 6540 & Fratercula arctica & 0.0 & 0.0 & 0.0 & 0.0 & 0.0 & 0.0 & 0.0 \\
\hline Germany & DE01 & 220 & Fulmarus glacialis & 0.0 & 0.0 & 0.0 & 0.0 & 0.0 & 0.0 & 0.0 \\
\hline Germany & DE01 & 59 & Gavia sp & 0.0 & 0.0 & 0.0 & 0.0 & 0.0 & 0.0 & 0.0 \\
\hline Germany & DE01 & 2130 & Melanitta nigra & 0.0 & 0.0 & 0.0 & 0.0 & 0.0 & 0.0 & 0.0 \\
\hline Germany & DE01 & 710 & Morus bassanus & 0.0 & 0.0 & 0.0 & 0.0 & 0.0 & 0.0 & 0.0 \\
\hline Germany & DE01 & 720 & Phalacrocorax carbo & 0.0 & 0.0 & 0.0 & 0.0 & 0.0 & 0.0 & 0.0 \\
\hline Germany & DE01 & 2060 & Somoteria mollissima & 0.0 & 0.0 & 0.0 & 0.0 & 0.0 & 0.0 & 0.0 \\
\hline Germany & DE01 & 6110 & Thalasseus sandvicensis & 0.0 & 0.0 & 0.0 & 0.0 & 0.1 & 0.0 & 0.1 \\
\hline Germany & DE01 & 6340 & Uria aalge & 0.0 & 0.5 & 0.3 & 0.2 & 0.0 & 0.0 & 0.9 \\
\hline Germany & DE02 & 6360 & Alca torda & 0.0 & 1.2 & 0.0 & 0.3 & 0.0 & 0.0 & 1.5 \\
\hline Germany & $\mathrm{DE} 02$ & 6540 & Fratercula arctica & 0.0 & 0.0 & 0.0 & 0.0 & 0.0 & 0.0 & 0.0 \\
\hline Germany & $\mathrm{DE} 02$ & 220 & Fulmarus glacialis & 0.2 & 0.0 & 0.2 & 0.2 & 0.0 & 0.7 & 1.3 \\
\hline Germany & DE02 & 59 & Gavia sp & 0.0 & 0.0 & 0.8 & 0.8 & 1.1 & 0.0 & 2.6 \\
\hline Germany & $\mathrm{DE} 02$ & 2130 & Melanitta nigra & 0.0 & 0.0 & 0.0 & 0.0 & 0.0 & 0.0 & 0.0 \\
\hline Germany & DE02 & 710 & Morus bassanus & 0.3 & 0.0 & 0.0 & 0.3 & 0.2 & 0.1 & 0.8 \\
\hline Germany & $\mathrm{DE} 02$ & 720 & Phalacrocorax carbo & 0.0 & 0.0 & 0.0 & 0.0 & 0.0 & 0.0 & 0.0 \\
\hline Germany & DE02 & 2060 & Somoteria mollissima & 0.0 & 0.0 & 0.0 & 0.0 & 0.0 & 0.0 & 0.0 \\
\hline Germany & DE02 & 6110 & Thalasseus sandvicensis & 0.0 & 0.0 & 0.0 & 0.0 & 0.1 & 0.0 & 0.1 \\
\hline Germany & DE02 & 6340 & Uria aalge & 0.6 & 1.6 & 5.7 & 0.6 & 0.1 & 0.1 & 8.7 \\
\hline Germany & DE03 & 6360 & Alca torda & 0.0 & 2.5 & 1.7 & 2.8 & 0.8 & 0.0 & 7.8 \\
\hline Germany & DE03 & 6540 & Fratercula arctica & 0.0 & 0.0 & 0.2 & 0.0 & 0.0 & 0.0 & 0.2 \\
\hline Germany & DE03 & 220 & Fulmarus glacialis & 0.1 & 0.1 & 0.0 & 0.1 & 0.1 & 0.1 & 0.5 \\
\hline Germany & DE03 & 59 & Gavia sp & 0.0 & 0.0 & 0.1 & 0.2 & 1.3 & 0.0 & 1.6 \\
\hline Germany & DE03 & 2130 & Melanitta nigra & 0.0 & 0.2 & 0.0 & 0.0 & 0.2 & 0.0 & 0.4 \\
\hline Germany & DE03 & 710 & Morus bassanus & 0.3 & 0.2 & 0.1 & 0.1 & 0.3 & 0.2 & 1.2 \\
\hline Germany & DE03 & 720 & Phalacrocorax carbo & 0.0 & 0.0 & 0.0 & 0.0 & 0.0 & 0.0 & 0.0 \\
\hline Germany & DE03 & 2060 & Somoteria mollissima & 0.0 & 0.0 & 0.0 & 0.0 & 0.0 & 0.0 & 0.0 \\
\hline Germany & DE03 & 6110 & Thalasseus sandvicensis & 0.3 & 0.0 & 0.0 & 0.0 & 0.2 & 0.0 & 0.4 \\
\hline Germany & DE03 & 6340 & Uria aalge & 0.7 & 7.1 & 17.4 & 3.1 & 2.4 & 1.0 & 31.6 \\
\hline Germany & DE04 & 6360 & Alca torda & 0.0 & 1.0 & 0.4 & 0.2 & 0.0 & 0.0 & 1.6 \\
\hline Germany & DE04 & 6540 & Fratercula arctica & 0.0 & 0.0 & 0.0 & 0.0 & 0.0 & 0.0 & 0.0 \\
\hline Germany & DE04 & 220 & Fulmarus glacialis & 0.0 & 0.0 & 0.0 & 0.0 & 0.0 & 0.0 & 0.2 \\
\hline Germany & DE04 & 59 & Gavia sp & 0.0 & 0.1 & 0.0 & 0.3 & 2.7 & 0.0 & 3.1 \\
\hline Germany & DE04 & 2130 & Melanitta nigra & 0.0 & 0.0 & 0.0 & 0.0 & 0.0 & 0.0 & 0.0 \\
\hline Germany & DE04 & 710 & Morus bassanus & 0.2 & 0.2 & 0.1 & 0.1 & 0.1 & 0.1 & 0.8 \\
\hline Germany & DE04 & 720 & Phalacrocorax carbo & 0.0 & 0.0 & 0.0 & 0.0 & 0.0 & 0.0 & 0.0 \\
\hline Germany & DE04 & 2060 & Somoteria mollissima & 0.0 & 0.0 & 0.0 & 0.0 & 0.0 & 0.0 & 0.0 \\
\hline Germany & DE04 & 6110 & Thalasseus sandvicensis & 0.0 & 0.0 & 0.0 & 0.0 & 0.1 & 0.1 & 0.3 \\
\hline Germany & DE04 & 6340 & Uria aalge & 0.1 & 2.8 & 2.0 & 1.2 & 0.6 & 0.0 & 6.6 \\
\hline Germany & DE05 & 6360 & Alca torda & 0.0 & 0.2 & 0.0 & 0.0 & 0.0 & 0.0 & 0.2 \\
\hline Germany & DE05 & 6540 & Fratercula arctica & 0.0 & 0.0 & 0.0 & 0.0 & 0.0 & 0.0 & 0.0 \\
\hline
\end{tabular}




\begin{tabular}{|c|c|c|c|c|c|c|c|c|c|c|}
\hline CountryName & UniekID & EUring & species & Aug + Sep & Okt + Nov & Dec + Jan & Feb + Mar & Apr + May & Jun + Jul & Total \\
\hline Germany & DE05 & 220 & Fulmarus glacialis & 0.0 & 0.0 & 0.0 & 0.1 & 0.0 & 0.0 & 0.2 \\
\hline Germany & DE05 & 59 & Gavia sp & 0.0 & 0.4 & 21.2 & 1.0 & 1.0 & 0.0 & 23.5 \\
\hline Germany & DE05 & 2130 & Melanitta nigra & 0.0 & 0.1 & 0.1 & 0.0 & 0.0 & 0.0 & 0.1 \\
\hline Germany & DE05 & 710 & Morus bassanus & 0.2 & 0.0 & 0.0 & 0.1 & 0.0 & 0.1 & 0.5 \\
\hline Germany & DE05 & 720 & Phalacrocorax carbo & 0.0 & 0.0 & 0.0 & 0.0 & 0.0 & 0.0 & 0.0 \\
\hline Germany & DE05 & 2060 & Somoteria mollissima & 0.0 & 0.0 & 0.0 & 0.0 & 0.1 & 0.0 & 0.1 \\
\hline Germany & DE05 & 6110 & Thalasseus sandvicensis & 0.1 & 0.0 & 0.0 & 0.0 & 0.4 & 0.0 & 0.4 \\
\hline Germany & DE05 & 6340 & Uria aalge & 0.9 & 0.6 & 1.3 & 0.1 & 0.3 & 0.1 & 3.3 \\
\hline Germany & DE06 & 6360 & Alca torda & 0.0 & 0.1 & 0.0 & 0.1 & 0.0 & 0.0 & 0.2 \\
\hline Germany & DE06 & 6540 & Fratercula arctica & 0.0 & 0.0 & 0.0 & 0.0 & 0.0 & 0.0 & 0.0 \\
\hline Germany & DE06 & 220 & Fulmarus glacialis & 0.1 & 0.0 & 0.0 & 0.3 & 0.2 & 0.0 & 0.7 \\
\hline Germany & DE06 & 59 & Gavia sp & 0.0 & 0.1 & 9.8 & 0.2 & 1.8 & 0.0 & 12.0 \\
\hline Germany & DE06 & 2130 & Melanitta nigra & 0.0 & 0.0 & 0.0 & 0.0 & 0.0 & 0.0 & 0.0 \\
\hline Germany & DE06 & 710 & Morus bassanus & 0.1 & 0.1 & 0.0 & 0.4 & 0.4 & 0.3 & 1.2 \\
\hline Germany & DE06 & 720 & Phalacrocorax carbo & 0.0 & 0.0 & 0.0 & 0.0 & 0.0 & 0.0 & 0.0 \\
\hline Germany & DE06 & 2060 & Somoteria mollissima & 0.0 & 0.0 & 0.0 & 0.0 & 0.0 & 0.0 & 0.0 \\
\hline Germany & DE06 & 6110 & Thalasseus sandvicensis & 0.0 & 0.0 & 0.0 & 0.0 & 0.2 & 0.0 & 0.2 \\
\hline Germany & DE06 & 6340 & Uria aalge & 0.1 & 0.7 & 1.4 & 0.3 & 0.1 & 0.0 & 2.7 \\
\hline Germany & DE07 & 6360 & Alca torda & 0.0 & 0.2 & 0.0 & 0.1 & 0.0 & 0.0 & 0.4 \\
\hline Germany & DE07 & 6540 & Fratercula arctica & 0.0 & 0.0 & 0.0 & 0.0 & 0.0 & 0.0 & 0.0 \\
\hline Germany & DE07 & 220 & Fulmarus glacialis & 0.1 & 0.0 & 0.0 & 0.2 & 0.2 & 0.1 & 0.6 \\
\hline Germany & DE07 & 59 & Gavia sp & 0.0 & 0.2 & 5.8 & 0.4 & 4.4 & 0.0 & 10.7 \\
\hline Germany & DE07 & 2130 & Melanitta nigra & 0.0 & 0.0 & 0.0 & 0.0 & 0.0 & 0.0 & 0.0 \\
\hline Germany & DE07 & 710 & Morus bassanus & 0.1 & 0.0 & 0.0 & 0.3 & 0.3 & 0.3 & 1.1 \\
\hline Germany & DE07 & 720 & Phalacrocorax carbo & 0.0 & 0.0 & 0.0 & 0.0 & 0.0 & 0.0 & 0.0 \\
\hline Germany & DE07 & 2060 & Somoteria mollissima & 0.0 & 0.0 & 0.0 & 0.0 & 0.0 & 0.0 & 0.0 \\
\hline Germany & DE07 & 6110 & Thalasseus sandvicensis & 0.0 & 0.0 & 0.0 & 0.0 & 0.2 & 0.0 & 0.2 \\
\hline Germany & DE07 & 6340 & Uria aalge & 0.3 & 1.2 & 1.3 & 1.4 & 0.3 & 0.1 & 4.6 \\
\hline Germany & DE08 & 6360 & Alca torda & 0.0 & 0.1 & 0.1 & 0.0 & 0.0 & 0.0 & 0.2 \\
\hline Germany & DE08 & 6540 & Fratercula arctica & 0.0 & 0.0 & 0.0 & 0.0 & 0.0 & 0.0 & 0.0 \\
\hline Germany & DE08 & 220 & Fulmarus glacialis & 0.0 & 0.0 & 0.0 & 0.0 & 0.0 & 0.0 & 0.1 \\
\hline Germany & DE08 & 59 & Gavia sp & 0.0 & 0.0 & 3.9 & 0.4 & 4.0 & 0.0 & 8.3 \\
\hline Germany & DE08 & 2130 & Melanitta nigra & 0.0 & 0.0 & 0.0 & 3.4 & 0.0 & 0.0 & 3.4 \\
\hline Germany & DE08 & 710 & Morus bassanus & 0.0 & 0.1 & 0.0 & 0.1 & 0.1 & 0.1 & 0.5 \\
\hline Germany & DE08 & 720 & Phalacrocorax carbo & 0.0 & 0.0 & 0.0 & 0.0 & 0.0 & 0.0 & 0.0 \\
\hline Germany & DE08 & 2060 & Somoteria mollissima & 0.0 & 0.0 & 0.0 & 0.0 & 0.0 & 0.0 & 0.0 \\
\hline Germany & DE08 & 6110 & Thalasseus sandvicensis & 0.0 & 0.0 & 0.0 & 0.0 & 0.2 & 0.0 & 0.2 \\
\hline Germany & DE08 & 6340 & Uria aalge & 0.2 & 0.3 & 2.4 & 0.2 & 0.0 & 0.0 & 3.1 \\
\hline Germany & DE09 & 6360 & Alca torda & 0.0 & 0.4 & 0.0 & 0.1 & 0.0 & 0.0 & 0.6 \\
\hline Germany & DE09 & 6540 & Fratercula arctica & 0.0 & 0.0 & 0.5 & 0.0 & 0.0 & 0.0 & 0.5 \\
\hline Germany & DE09 & 220 & Fulmarus glacialis & 0.1 & 0.0 & 0.3 & 0.2 & 0.2 & 0.1 & 0.8 \\
\hline Germany & DE09 & 59 & Gavia sp & 0.0 & 0.0 & 0.0 & 0.0 & 0.1 & 0.0 & 0.1 \\
\hline Germany & DE09 & 2130 & Melanitta nigra & 0.0 & 0.0 & 0.0 & 0.0 & 0.0 & 0.0 & 0.0 \\
\hline Germany & DE09 & 710 & Morus bassanus & 0.1 & 0.0 & 0.7 & 0.0 & 0.2 & 0.1 & 1.1 \\
\hline Germany & DE09 & 720 & Phalacrocorax carbo & 0.0 & 0.0 & 0.0 & 0.0 & 0.0 & 0.0 & 0.0 \\
\hline Germany & DE09 & 2060 & Somoteria mollissima & 0.0 & 0.0 & 0.0 & 0.0 & 0.0 & 0.0 & 0.0 \\
\hline Germany & DE09 & 6110 & Thalasseus sandvicensis & 0.0 & 0.0 & 0.0 & 0.0 & 0.0 & 0.0 & 0.0 \\
\hline Germany & DE09 & 6340 & Uria aalge & 2.2 & 0.4 & 0.6 & 0.3 & 1.6 & 6.0 & 11.2 \\
\hline Germany & $\mathrm{DEOH}$ & 6360 & Alca torda & 0.0 & 1.1 & 1.5 & 0.1 & 0.0 & 0.0 & 2.7 \\
\hline Germany & $\mathrm{DEOH}$ & 6540 & Fratercula arctica & 0.0 & 0.0 & 0.0 & 0.0 & 0.0 & 0.0 & 0.0 \\
\hline Germany & $\mathrm{DEOH}$ & 220 & Fulmarus glacialis & 0.0 & 0.0 & 0.0 & 0.0 & 0.1 & 0.1 & 0.2 \\
\hline Germany & $\mathrm{DEOH}$ & 59 & Gavia sp & 0.0 & 0.0 & 0.0 & 0.2 & 0.5 & 0.0 & 0.7 \\
\hline Germany & $\mathrm{DEOH}$ & 2130 & Melanitta nigra & 0.0 & 0.0 & 0.2 & 0.0 & 0.0 & 0.0 & 0.2 \\
\hline Germany & $\mathrm{DEOH}$ & 710 & Morus bassanus & 0.1 & 0.0 & 0.1 & 0.0 & 0.0 & 0.1 & 0.3 \\
\hline Germany & $\mathrm{DEOH}$ & 720 & Phalacrocorax carbo & 0.0 & 0.0 & 0.0 & 0.0 & 0.0 & 0.0 & 0.0 \\
\hline Germany & $\mathrm{DE} 0 \mathrm{H}$ & 2060 & Somoteria mollissima & 0.0 & 0.0 & 0.0 & 0.0 & 0.0 & 0.0 & 0.0 \\
\hline
\end{tabular}




\begin{tabular}{|c|c|c|c|c|c|c|c|c|c|c|}
\hline CountryName & UniekID & EUring & species & Aug + Sep & Okt + Nov & Dec + Jan & Feb + Mar & Apr + May & Jun + Jul & Total \\
\hline Germany & $\mathrm{DE} 0 \mathrm{H}$ & 6110 & Thalasseus sandvicensis & 0.0 & 0.0 & 0.0 & 0.0 & 0.0 & 0.0 & $\overline{0.0}$ \\
\hline Germany & $\mathrm{DEOH}$ & 6340 & Uria aalge & 0.4 & 0.4 & 2.1 & 0.7 & 0.2 & 0.0 & 3.9 \\
\hline Germany & DE0K & 6360 & Alca torda & 0.0 & 0.5 & 0.4 & 0.4 & 0.0 & 0.0 & 1.4 \\
\hline Germany & DE0K & 6540 & Fratercula arctica & 0.0 & 0.0 & 0.0 & 0.0 & 0.0 & 0.0 & 0.0 \\
\hline Germany & DEOK & 220 & Fulmarus glacialis & 0.0 & 0.0 & 0.0 & 0.0 & 0.0 & 0.0 & 0.1 \\
\hline Germany & DE0K & 59 & Gavia sp & 0.0 & 0.0 & 0.0 & 4.1 & 2.9 & 0.0 & 7.0 \\
\hline Germany & DE0K & 2130 & Melanitta nigra & 0.0 & 0.0 & 0.0 & 0.0 & 0.0 & 0.0 & 0.0 \\
\hline Germany & DE0K & 710 & Morus bassanus & 0.1 & 0.1 & 0.0 & 0.1 & 0.1 & 0.1 & 0.5 \\
\hline Germany & DE0K & 720 & Phalacrocorax carbo & 0.0 & 0.0 & 0.0 & 0.0 & 0.0 & 0.0 & 0.0 \\
\hline Germany & DE0K & 2060 & Somoteria mollissima & 0.0 & 0.0 & 0.0 & 0.0 & 0.0 & 0.0 & 0.0 \\
\hline Germany & DE0K & 6110 & Thalasseus sandvicensis & 0.0 & 0.0 & 0.0 & 0.0 & 0.1 & 0.0 & 0.1 \\
\hline Germany & DE0K & 6340 & Uria aalge & 0.1 & 2.7 & 2.7 & 0.6 & 0.4 & 0.0 & 6.6 \\
\hline Germany & DE11 & 6360 & Alca torda & 0.0 & 1.5 & 0.2 & 0.3 & 0.0 & 0.0 & 1.9 \\
\hline Germany & DE11 & 6540 & Fratercula arctica & 0.0 & 0.0 & 0.4 & 0.0 & 0.0 & 0.0 & 0.4 \\
\hline Germany & DE11 & 220 & Fulmarus glacialis & 0.1 & 0.0 & 0.2 & 0.1 & 0.2 & 0.1 & 0.7 \\
\hline Germany & DE11 & 59 & Gavia sp & 0.0 & 0.0 & 0.0 & 0.0 & 0.0 & 0.0 & 0.0 \\
\hline Germany & DE11 & 2130 & Melanitta nigra & 0.0 & 0.0 & 0.0 & 0.0 & 0.0 & 0.0 & 0.0 \\
\hline Germany & DE11 & 710 & Morus bassanus & 0.1 & 0.0 & 0.7 & 0.0 & 0.2 & 0.1 & 1.1 \\
\hline Germany & DE11 & 720 & Phalacrocorax carbo & 0.0 & 0.0 & 0.0 & 0.0 & 0.0 & 0.0 & 0.0 \\
\hline Germany & DE11 & 2060 & Somoteria mollissima & 0.0 & 0.0 & 0.0 & 0.0 & 0.0 & 0.0 & 0.0 \\
\hline Germany & DE11 & 6110 & Thalasseus sandvicensis & 0.0 & 0.0 & 0.0 & 0.0 & 0.0 & 0.0 & 0.0 \\
\hline Germany & DE11 & 6340 & Uria aalge & 1.3 & 1.1 & 2.8 & 0.4 & 1.1 & 3.5 & 10.2 \\
\hline Germany & DE12 & 6360 & Alca torda & 0.0 & 0.5 & 0.5 & 0.1 & 0.0 & 0.0 & 1.0 \\
\hline Germany & DE12 & 6540 & Fratercula arctica & 0.0 & 0.0 & 0.0 & 0.0 & 0.0 & 0.0 & 0.0 \\
\hline Germany & DE12 & 220 & Fulmarus glacialis & 0.2 & 0.1 & 0.8 & 0.5 & 0.0 & 0.3 & 1.9 \\
\hline Germany & DE12 & 59 & Gavia sp & 0.0 & 0.3 & 0.4 & 0.9 & 3.3 & 0.0 & 5.0 \\
\hline Germany & DE12 & 2130 & Melanitta nigra & 0.0 & 0.0 & 0.0 & 0.0 & 0.0 & 0.0 & 0.0 \\
\hline Germany & DE12 & 710 & Morus bassanus & 0.2 & 0.0 & 0.0 & 0.3 & 0.4 & 0.1 & 1.0 \\
\hline Germany & DE12 & 720 & Phalacrocorax carbo & 0.0 & 0.0 & 0.0 & 0.0 & 0.0 & 0.0 & 0.0 \\
\hline Germany & DE12 & 2060 & Somoteria mollissima & 0.0 & 0.0 & 0.0 & 0.0 & 0.0 & 0.0 & 0.0 \\
\hline Germany & DE12 & 6110 & Thalasseus sandvicensis & 0.0 & 0.0 & 0.0 & 0.0 & 0.2 & 0.0 & 0.2 \\
\hline Germany & DE12 & 6340 & Uria aalge & 1.4 & 1.4 & 0.4 & 1.1 & 0.4 & 0.7 & 5.4 \\
\hline Germany & DE13 & 6360 & Alca torda & 0.0 & 1.0 & 3.5 & 0.4 & 0.0 & 0.0 & 4.9 \\
\hline Germany & DE13 & 6540 & Fratercula arctica & 0.0 & 0.0 & 0.0 & 0.0 & 0.0 & 0.0 & 0.0 \\
\hline Germany & DE13 & 220 & Fulmarus glacialis & 0.0 & 0.1 & 0.0 & 0.0 & 0.1 & 0.2 & 0.5 \\
\hline Germany & DE13 & 59 & Gavia sp & 0.0 & 0.1 & 0.0 & 0.4 & 1.2 & 0.0 & 1.7 \\
\hline Germany & DE13 & 2130 & Melanitta nigra & 0.0 & 0.0 & 0.3 & 0.0 & 0.0 & 0.0 & 0.4 \\
\hline Germany & DE13 & 710 & Morus bassanus & 0.4 & 0.1 & 0.2 & 0.1 & 0.1 & 0.3 & 1.2 \\
\hline Germany & DE13 & 720 & Phalacrocorax carbo & 0.0 & 0.0 & 0.0 & 0.0 & 0.0 & 0.0 & 0.0 \\
\hline Germany & DE13 & 2060 & Somoteria mollissima & 0.0 & 0.0 & 0.0 & 0.0 & 0.0 & 0.0 & 0.0 \\
\hline Germany & DE13 & 6110 & Thalasseus sandvicensis & 0.0 & 0.0 & 0.0 & 0.0 & 0.0 & 0.0 & 0.0 \\
\hline Germany & DE13 & 6340 & Uria aalge & 0.4 & 2.0 & 5.7 & 1.4 & 0.7 & 0.0 & 10.1 \\
\hline Germany & DE19 & 6360 & Alca torda & 0.0 & 1.6 & 0.8 & 0.2 & 0.0 & 0.0 & 2.6 \\
\hline Germany & DE19 & 6540 & Fratercula arctica & 0.1 & 0.0 & 0.0 & 0.0 & 0.0 & 0.0 & 0.1 \\
\hline Germany & DE19 & 220 & Fulmarus glacialis & 0.1 & 0.1 & 0.2 & 0.1 & 0.2 & 0.1 & 0.8 \\
\hline Germany & DE19 & 59 & Gavia sp & 0.0 & 0.0 & 0.0 & 0.0 & 0.0 & 0.0 & 0.0 \\
\hline Germany & DE19 & 2130 & Melanitta nigra & 0.0 & 0.0 & 0.0 & 0.0 & 0.0 & 0.0 & 0.0 \\
\hline Germany & DE19 & 710 & Morus bassanus & 0.3 & 0.1 & 0.3 & 0.2 & 0.2 & 0.2 & 1.3 \\
\hline Germany & DE19 & 720 & Phalacrocorax carbo & 0.0 & 0.0 & 0.0 & 0.0 & 0.0 & 0.0 & 0.0 \\
\hline Germany & DE19 & 2060 & Somoteria mollissima & 0.0 & 0.0 & 0.0 & 0.0 & 0.0 & 0.0 & 0.0 \\
\hline Germany & DE19 & 6110 & Thalasseus sandvicensis & 0.1 & 0.0 & 0.0 & 0.0 & 0.0 & 0.0 & 0.1 \\
\hline Germany & DE19 & 6340 & Uria aalge & 6.0 & 2.3 & 10.6 & 1.7 & 1.1 & 2.2 & 23.9 \\
\hline Germany & DE20 & 6360 & Alca torda & 0.0 & 0.0 & 0.1 & 0.0 & 0.0 & 0.0 & 0.1 \\
\hline Germany & DE20 & 6540 & Fratercula arctica & 0.0 & 0.0 & 0.0 & 0.0 & 0.0 & 0.0 & 0.0 \\
\hline Germany & DE20 & 220 & Fulmarus glacialis & 0.0 & 0.0 & 0.0 & 0.0 & 0.0 & 0.0 & 0.0 \\
\hline Germany & DE20 & 59 & Gavia sp & 0.0 & 0.0 & 0.7 & 0.1 & 0.0 & 0.0 & 0.7 \\
\hline
\end{tabular}




\begin{tabular}{|c|c|c|c|c|c|c|c|c|c|c|}
\hline CountryName & UniekID & EUring & species & Aug + Sep & Okt + Nov & Dec + Jan & Feb + Mar & Apr + May & Jun + Jul & Total \\
\hline Germany & DE20 & 2130 & Melanitta nigra & 0.0 & 0.0 & 39.3 & 0.0 & 0.1 & 0.0 & 39.3 \\
\hline Germany & DE20 & 710 & Morus bassanus & 0.0 & 0.0 & 0.0 & 0.0 & 0.0 & 0.0 & 0.1 \\
\hline Germany & DE20 & 720 & Phalacrocorax carbo & 0.0 & 0.0 & 0.0 & 0.0 & 0.0 & 0.0 & 0.0 \\
\hline Germany & DE20 & 2060 & Somoteria mollissima & 0.0 & 0.0 & 6.2 & 14.5 & 0.0 & 0.0 & 20.8 \\
\hline Germany & DE20 & 6110 & Thalasseus sandvicensis & 0.2 & 0.0 & 0.0 & 0.0 & 0.0 & 0.2 & 0.4 \\
\hline Germany & DE20 & 6340 & Uria aalge & 0.0 & 0.0 & 0.2 & 0.0 & 0.0 & 0.0 & 0.2 \\
\hline Germany & DE21 & 6360 & Alca torda & 0.0 & 0.1 & 0.1 & 0.0 & 0.0 & 0.0 & 0.3 \\
\hline Germany & DE21 & 6540 & Fratercula arctica & 0.0 & 0.0 & 0.0 & 0.0 & 0.0 & 0.0 & 0.0 \\
\hline Germany & DE21 & 220 & Fulmarus glacialis & 0.0 & 0.0 & 0.0 & 0.0 & 0.0 & 0.0 & 0.0 \\
\hline Germany & DE21 & 59 & Gavia sp & 0.0 & 0.7 & 0.9 & 0.0 & 0.1 & 0.0 & 1.7 \\
\hline Germany & DE21 & 2130 & Melanitta nigra & 0.0 & 0.9 & 1.2 & 0.3 & 8.0 & 0.0 & 10.4 \\
\hline Germany & DE21 & 710 & Morus bassanus & 0.0 & 0.0 & 0.0 & 0.0 & 0.0 & 0.0 & 0.1 \\
\hline Germany & DE21 & 720 & Phalacrocorax carbo & 0.0 & 0.0 & 0.0 & 0.0 & 0.0 & 0.0 & 0.0 \\
\hline Germany & DE21 & 2060 & Somoteria mollissima & 0.0 & 0.0 & 0.0 & 0.0 & 0.0 & 0.0 & 0.0 \\
\hline Germany & DE21 & 6110 & Thalasseus sandvicensis & 0.2 & 0.0 & 0.0 & 0.0 & 0.1 & 0.0 & 0.3 \\
\hline Germany & DE21 & 6340 & Uria aalge & 0.1 & 0.3 & 0.6 & 0.0 & 0.0 & 0.0 & 1.0 \\
\hline Germany & DE23 & 6360 & Alca torda & 0.0 & 0.1 & 0.4 & 0.0 & 0.0 & 0.0 & 0.5 \\
\hline Germany & DE23 & 6540 & Fratercula arctica & 0.0 & 0.0 & 0.0 & 0.0 & 0.0 & 0.0 & 0.0 \\
\hline Germany & DE23 & 220 & Fulmarus glacialis & 0.2 & 0.1 & 0.2 & 0.0 & 0.1 & 0.2 & 0.8 \\
\hline Germany & DE23 & 59 & Gavia sp & 0.0 & 0.0 & 0.0 & 0.0 & 0.0 & 0.0 & 0.0 \\
\hline Germany & DE23 & 2130 & Melanitta nigra & 0.0 & 0.0 & 0.0 & 0.0 & 0.0 & 0.0 & 0.0 \\
\hline Germany & DE23 & 710 & Morus bassanus & 0.3 & 0.1 & 0.0 & 0.1 & 0.0 & 0.3 & 0.8 \\
\hline Germany & DE23 & 720 & Phalacrocorax carbo & 0.0 & 0.0 & 0.0 & 0.0 & 0.0 & 0.0 & 0.0 \\
\hline Germany & DE23 & 2060 & Somoteria mollissima & 0.0 & 0.0 & 0.0 & 0.0 & 0.0 & 0.0 & 0.0 \\
\hline Germany & DE23 & 6110 & Thalasseus sandvicensis & 0.0 & 0.0 & 0.0 & 0.0 & 0.0 & 0.0 & 0.0 \\
\hline Germany & DE23 & 6340 & Uria aalge & 12.0 & 0.6 & 1.0 & 0.2 & 1.9 & 0.4 & 16.1 \\
\hline Germany & DE24 & 6360 & Alca torda & 0.1 & 0.0 & 0.2 & 0.1 & 0.0 & 0.0 & 0.4 \\
\hline Germany & DE24 & 6540 & Fratercula arctica & 0.0 & 0.0 & 0.0 & 0.0 & 0.0 & 0.0 & 0.0 \\
\hline Germany & DE24 & 220 & Fulmarus glacialis & 0.0 & 0.0 & 0.1 & 0.0 & 0.0 & 0.0 & 0.2 \\
\hline Germany & DE24 & 59 & Gavia sp & 0.0 & 0.2 & 0.0 & 0.0 & 0.0 & 0.0 & 0.2 \\
\hline Germany & DE24 & 2130 & Melanitta nigra & 0.0 & 0.0 & 0.0 & 0.0 & 0.0 & 0.0 & 0.0 \\
\hline Germany & DE24 & 710 & Morus bassanus & 0.1 & 0.0 & 0.0 & 0.0 & 0.0 & 0.1 & 0.2 \\
\hline Germany & DE24 & 720 & Phalacrocorax carbo & 0.0 & 0.0 & 0.0 & 0.0 & 0.0 & 0.0 & 0.0 \\
\hline Germany & DE24 & 2060 & Somoteria mollissima & 0.0 & 0.0 & 0.0 & 0.0 & 0.0 & 0.0 & 0.0 \\
\hline Germany & DE24 & 6110 & Thalasseus sandvicensis & 0.0 & 0.0 & 0.0 & 0.0 & 0.0 & 0.0 & 0.0 \\
\hline Germany & DE24 & 6340 & Uria aalge & 1.8 & 0.7 & 0.3 & 0.6 & 1.8 & 0.4 & 5.7 \\
\hline Germany & DE26 & 6360 & Alca torda & 0.0 & 0.7 & 0.5 & 0.1 & 0.0 & 0.0 & 1.3 \\
\hline Germany & DE26 & 6540 & Fratercula arctica & 0.0 & 0.0 & 0.0 & 0.0 & 0.0 & 0.0 & 0.0 \\
\hline Germany & DE26 & 220 & Fulmarus glacialis & 0.0 & 0.0 & 0.0 & 0.0 & 0.0 & 0.0 & 0.1 \\
\hline Germany & DE26 & 59 & Gavia sp & 0.0 & 0.0 & 0.1 & 0.0 & 0.4 & 0.0 & 0.5 \\
\hline Germany & DE26 & 2130 & Melanitta nigra & 0.0 & 0.0 & 0.0 & 0.0 & 0.0 & 0.0 & 0.0 \\
\hline Germany & DE26 & 710 & Morus bassanus & 0.1 & 0.0 & 0.0 & 0.1 & 0.1 & 0.1 & 0.5 \\
\hline Germany & DE26 & 720 & Phalacrocorax carbo & 0.0 & 0.0 & 0.0 & 0.0 & 0.0 & 0.0 & 0.0 \\
\hline Germany & DE26 & 2060 & Somoteria mollissima & 0.0 & 0.0 & 0.0 & 0.0 & 0.0 & 0.0 & 0.0 \\
\hline Germany & DE26 & 6110 & Thalasseus sandvicensis & 0.0 & 0.0 & 0.0 & 0.0 & 0.1 & 0.1 & 0.2 \\
\hline Germany & DE26 & 6340 & Uria aalge & 0.1 & 2.5 & 2.6 & 1.4 & 0.3 & 0.0 & 7.0 \\
\hline Germany & DE27 & 6360 & Alca torda & 0.0 & 0.5 & 0.4 & 0.3 & 0.0 & 0.0 & 1.2 \\
\hline Germany & DE27 & 6540 & Fratercula arctica & 0.0 & 0.0 & 0.0 & 0.0 & 0.0 & 0.0 & 0.0 \\
\hline Germany & DE27 & 220 & Fulmarus glacialis & 0.0 & 0.0 & 0.0 & 0.0 & 0.0 & 0.0 & 0.1 \\
\hline Germany & DE27 & 59 & Gavia sp & 0.0 & 0.0 & 0.0 & 0.8 & 2.1 & 0.0 & 2.9 \\
\hline Germany & DE27 & 2130 & Melanitta nigra & 0.0 & 0.0 & 0.0 & 0.0 & 0.0 & 0.0 & 0.0 \\
\hline Germany & DE27 & 710 & Morus bassanus & 0.1 & 0.1 & 0.0 & 0.1 & 0.1 & 0.1 & 0.4 \\
\hline Germany & DE27 & 720 & Phalacrocorax carbo & 0.0 & 0.0 & 0.0 & 0.0 & 0.0 & 0.0 & 0.0 \\
\hline Germany & DE27 & 2060 & Somoteria mollissima & 0.0 & 0.0 & 0.0 & 0.0 & 0.0 & 0.0 & 0.0 \\
\hline Germany & DE27 & 6110 & Thalasseus sandvicensis & 0.0 & 0.0 & 0.0 & 0.0 & 0.1 & 0.0 & 0.1 \\
\hline Germany & DE27 & 6340 & Uria aalge & 0.1 & 2.4 & 2.1 & 0.7 & 0.4 & 0.0 & 5.7 \\
\hline
\end{tabular}




\begin{tabular}{|c|c|c|c|c|c|c|c|c|c|c|}
\hline CountryName & UniekID & EUring & species & Aug + Sep & Okt + Nov & Dec + Jan & Feb + Mar & Apr + May & Jun + Jul & Total \\
\hline Germany & DE28 & 6360 & Alca torda & 0.0 & 0.4 & 0.0 & 0.0 & 0.0 & 0.0 & 0.4 \\
\hline Germany & DE28 & 6540 & Fratercula arctica & 0.0 & 0.0 & 0.0 & 0.0 & 0.0 & 0.0 & 0.0 \\
\hline Germany & DE28 & 220 & Fulmarus glacialis & 0.0 & 0.0 & 0.0 & 0.0 & 0.0 & 0.1 & 0.2 \\
\hline Germany & DE28 & 59 & Gavia sp & 0.0 & 0.0 & 0.0 & 0.0 & 2.3 & 0.0 & 2.3 \\
\hline Germany & DE28 & 2130 & Melanitta nigra & 0.0 & 0.0 & 0.0 & 0.0 & 0.0 & 0.0 & 0.0 \\
\hline Germany & DE28 & 710 & Morus bassanus & 0.1 & 0.1 & 0.1 & 0.0 & 0.0 & 0.1 & 0.5 \\
\hline Germany & DE28 & 720 & Phalacrocorax carbo & 0.0 & 0.0 & 0.0 & 0.0 & 0.0 & 0.0 & 0.0 \\
\hline Germany & DE28 & 2060 & Somoteria mollissima & 0.0 & 0.0 & 0.0 & 0.0 & 0.0 & 0.0 & 0.0 \\
\hline Germany & DE28 & 6110 & Thalasseus sandvicensis & 0.0 & 0.0 & 0.0 & 0.0 & 0.0 & 0.0 & 0.0 \\
\hline Germany & DE28 & 6340 & Uria aalge & 0.0 & 1.3 & 0.8 & 0.2 & 0.3 & 0.0 & 2.6 \\
\hline Germany & DE2Q & 6360 & Alca torda & 0.0 & 0.5 & 0.1 & 0.1 & 0.0 & 0.0 & 0.7 \\
\hline Germany & DE2Q & 6540 & Fratercula arctica & 0.0 & 0.0 & 0.0 & 0.0 & 0.0 & 0.0 & 0.0 \\
\hline Germany & DE2Q & 220 & Fulmarus glacialis & 0.0 & 0.1 & 0.0 & 0.0 & 0.0 & 0.1 & 0.2 \\
\hline Germany & DE2Q & 59 & Gavia sp & 0.0 & 0.1 & 0.0 & 0.7 & 1.2 & 0.0 & 2.0 \\
\hline Germany & DE2Q & 2130 & Melanitta nigra & 0.0 & 0.1 & 0.0 & 0.0 & 0.0 & 0.0 & 0.1 \\
\hline Germany & DE2Q & 710 & Morus bassanus & 0.2 & 0.1 & 0.1 & 0.1 & 0.1 & 0.1 & 0.7 \\
\hline Germany & $\mathrm{DE} 2 \mathrm{Q}$ & 720 & Phalacrocorax carbo & 0.0 & 0.0 & 0.0 & 0.0 & 0.0 & 0.0 & 0.0 \\
\hline Germany & DE2Q & 2060 & Somoteria mollissima & 0.0 & 0.0 & 0.0 & 0.0 & 0.0 & 0.0 & 0.0 \\
\hline Germany & DE2Q & 6110 & Thalasseus sandvicensis & 0.0 & 0.0 & 0.0 & 0.0 & 0.0 & 0.0 & 0.0 \\
\hline Germany & DE2Q & 6340 & Uria aalge & 0.0 & 1.3 & 1.5 & 0.2 & 0.5 & 0.0 & 3.4 \\
\hline Germany & DE2R & 6360 & Alca torda & 0.0 & 0.5 & 0.1 & 0.1 & 0.0 & 0.0 & 0.7 \\
\hline Germany & $\mathrm{DE} 2 \mathrm{R}$ & 6540 & Fratercula arctica & 0.0 & 0.0 & 0.0 & 0.0 & 0.0 & 0.0 & 0.0 \\
\hline Germany & DE2R & 220 & Fulmarus glacialis & 0.0 & 0.1 & 0.0 & 0.0 & 0.0 & 0.1 & 0.2 \\
\hline Germany & DE2R & 59 & Gavia sp & 0.0 & 0.1 & 0.0 & 0.9 & 1.6 & 0.0 & 2.6 \\
\hline Germany & DE2R & 2130 & Melanitta nigra & 0.0 & 0.1 & 0.0 & 0.0 & 0.0 & 0.0 & 0.1 \\
\hline Germany & DE2R & 710 & Morus bassanus & 0.2 & 0.1 & 0.1 & 0.1 & 0.1 & 0.1 & 0.7 \\
\hline Germany & DE2R & 720 & Phalacrocorax carbo & 0.0 & 0.0 & 0.0 & 0.0 & 0.0 & 0.0 & 0.0 \\
\hline Germany & DE2R & 2060 & Somoteria mollissima & 0.0 & 0.0 & 0.0 & 0.0 & 0.0 & 0.0 & 0.0 \\
\hline Germany & DE2R & 6110 & Thalasseus sandvicensis & 0.0 & 0.0 & 0.0 & 0.0 & 0.1 & 0.0 & 0.1 \\
\hline Germany & DE2R & 6340 & Uria aalge & 0.0 & 1.4 & 1.7 & 0.2 & 0.5 & 0.0 & 3.9 \\
\hline Germany & $\mathrm{DE} 2 \mathrm{~S}$ & 6360 & Alca torda & 0.0 & 0.3 & 1.3 & 0.1 & 0.0 & 0.0 & 1.7 \\
\hline Germany & DE2S & 6540 & Fratercula arctica & 0.0 & 0.0 & 0.0 & 0.0 & 0.0 & 0.0 & 0.0 \\
\hline Germany & DE2S & 220 & Fulmarus glacialis & 0.0 & 0.0 & 0.0 & 0.0 & 0.0 & 0.1 & 0.1 \\
\hline Germany & DE2S & 59 & Gavia sp & 0.0 & 0.0 & 0.0 & 0.1 & 0.4 & 0.0 & 0.5 \\
\hline Germany & DE2S & 2130 & Melanitta nigra & 0.0 & 0.0 & 0.1 & 0.0 & 0.0 & 0.0 & 0.1 \\
\hline Germany & DE2S & 710 & Morus bassanus & 0.1 & 0.0 & 0.0 & 0.0 & 0.0 & 0.0 & 0.2 \\
\hline Germany & DE2S & 720 & Phalacrocorax carbo & 0.0 & 0.0 & 0.0 & 0.0 & 0.0 & 0.0 & 0.0 \\
\hline Germany & DE2S & 2060 & Somoteria mollissima & 0.0 & 0.0 & 0.0 & 0.0 & 0.0 & 0.0 & 0.0 \\
\hline Germany & DE2S & 6110 & Thalasseus sandvicensis & 0.0 & 0.0 & 0.0 & 0.0 & 0.0 & 0.0 & 0.0 \\
\hline Germany & DE2S & 6340 & Uria aalge & 0.2 & 0.3 & 1.8 & 0.3 & 0.2 & 0.0 & 2.8 \\
\hline Germany & DE2T & 6360 & Alca torda & 0.0 & 0.3 & 0.4 & 0.2 & 0.0 & 0.0 & 0.9 \\
\hline Germany & DE2T & 6540 & Fratercula arctica & 0.0 & 0.0 & 0.0 & 0.0 & 0.0 & 0.0 & 0.0 \\
\hline Germany & DE2T & 220 & Fulmarus glacialis & 0.0 & 0.1 & 0.0 & 0.0 & 0.0 & 0.1 & 0.2 \\
\hline Germany & DE2T & 59 & Gavia sp & 0.0 & 0.2 & 0.0 & 0.1 & 0.2 & 0.0 & 0.4 \\
\hline Germany & DE2T & 2130 & Melanitta nigra & 0.0 & 0.1 & 0.0 & 0.0 & 0.0 & 0.0 & 0.1 \\
\hline Germany & DE2T & 710 & Morus bassanus & 0.2 & 0.1 & 0.1 & 0.0 & 0.1 & 0.1 & 0.7 \\
\hline Germany & DE2T & 720 & Phalacrocorax carbo & 0.0 & 0.0 & 0.0 & 0.0 & 0.0 & 0.0 & 0.0 \\
\hline Germany & DE2T & 2060 & Somoteria mollissima & 0.0 & 0.0 & 0.0 & 0.0 & 0.0 & 0.0 & 0.0 \\
\hline Germany & DE2T & 6110 & Thalasseus sandvicensis & 0.0 & 0.0 & 0.0 & 0.0 & 0.0 & 0.0 & 0.0 \\
\hline Germany & DE2T & 6340 & Uria aalge & 0.0 & 1.3 & 1.6 & 0.3 & 0.7 & 0.0 & 3.9 \\
\hline Germany & DE2V & 6360 & Alca torda & 0.0 & 0.1 & 0.2 & 0.1 & 0.0 & 0.0 & 0.4 \\
\hline Germany & DE2V & 6540 & Fratercula arctica & 0.0 & 0.0 & 0.0 & 0.0 & 0.0 & 0.0 & 0.0 \\
\hline Germany & $\mathrm{DE} 2 \mathrm{~V}$ & 220 & Fulmarus glacialis & 0.1 & 0.1 & 0.1 & 0.0 & 0.0 & 0.2 & 0.4 \\
\hline Germany & DE2V & 59 & Gavia sp & 0.0 & 0.1 & 0.0 & 0.0 & 0.4 & 0.0 & 0.5 \\
\hline Germany & DE2V & 2130 & Melanitta nigra & 0.0 & 0.0 & 0.0 & 0.0 & 0.0 & 0.0 & 0.0 \\
\hline Germany & DE2V & 710 & Morus bassanus & 0.2 & 0.1 & 0.0 & 0.1 & 0.0 & 0.1 & 0.6 \\
\hline
\end{tabular}




\begin{tabular}{|c|c|c|c|c|c|c|c|c|c|c|}
\hline CountryName & UniekID & EUring & species & Aug + Sep & Okt + Nov & Dec + Jan & Feb + Mar & Apr + May & Jun + Jul & Total \\
\hline Germany & DE2V & 720 & Phalacrocorax carbo & 0.0 & 0.0 & 0.0 & 0.0 & 0.0 & 0.0 & 0.0 \\
\hline Germany & DE2V & 2060 & Somoteria mollissima & 0.0 & 0.0 & 0.0 & 0.0 & 0.0 & 0.0 & 0.0 \\
\hline Germany & DE2V & 6110 & Thalasseus sandvicensis & 0.0 & 0.0 & 0.0 & 0.0 & 0.1 & 0.0 & 0.1 \\
\hline Germany & DE2V & 6340 & Uria aalge & 7.9 & 1.0 & 2.3 & 0.9 & 2.0 & 2.3 & 16.3 \\
\hline Germany & DE2W & 6360 & Alca torda & 0.0 & 0.0 & 0.2 & 0.1 & 0.0 & 0.0 & 0.4 \\
\hline Germany & $\mathrm{DE} 2 \mathrm{~W}$ & 6540 & Fratercula arctica & 0.0 & 0.0 & 0.1 & 0.0 & 0.0 & 0.0 & 0.1 \\
\hline Germany & $\mathrm{DE} 2 \mathrm{~W}$ & 220 & Fulmarus glacialis & 0.1 & 0.0 & 0.1 & 0.0 & 0.0 & 0.0 & 0.3 \\
\hline Germany & DE2W & 59 & Gavia sp & 0.0 & 0.1 & 0.0 & 0.0 & 0.0 & 0.0 & 0.1 \\
\hline Germany & DE2W & 2130 & Melanitta nigra & 0.0 & 0.0 & 0.0 & 0.0 & 0.0 & 0.0 & 0.0 \\
\hline Germany & DE2W & 710 & Morus bassanus & 0.1 & 0.0 & 0.0 & 0.0 & 0.0 & 0.1 & 0.2 \\
\hline Germany & $\mathrm{DE} 2 \mathrm{~W}$ & 720 & Phalacrocorax carbo & 0.0 & 0.0 & 0.0 & 0.0 & 0.0 & 0.0 & 0.0 \\
\hline Germany & DE2W & 2060 & Somoteria mollissima & 0.0 & 0.0 & 0.0 & 0.0 & 0.0 & 0.0 & 0.0 \\
\hline Germany & $\mathrm{DE} 2 \mathrm{~W}$ & 6110 & Thalasseus sandvicensis & 0.0 & 0.0 & 0.0 & 0.0 & 0.0 & 0.0 & 0.0 \\
\hline Germany & DE2W & 6340 & Uria aalge & 1.3 & 0.5 & 0.2 & 0.2 & 1.6 & 0.3 & 4.1 \\
\hline Germany & DE2X & 6360 & Alca torda & 0.0 & 2.9 & 1.4 & 1.0 & 0.0 & 0.0 & 5.4 \\
\hline Germany & DE2X & 6540 & Fratercula arctica & 0.1 & 0.0 & 0.0 & 0.0 & 0.0 & 0.0 & 0.1 \\
\hline Germany & DE2X & 220 & Fulmarus glacialis & 0.2 & 0.1 & 0.2 & 0.0 & 0.1 & 0.2 & 0.8 \\
\hline Germany & DE2X & 59 & Gavia sp & 0.0 & 0.0 & 0.0 & 0.0 & 0.3 & 0.0 & 0.3 \\
\hline Germany & DE2X & 2130 & Melanitta nigra & 0.0 & 0.0 & 0.0 & 0.0 & 0.0 & 0.0 & 0.0 \\
\hline Germany & DE2X & 710 & Morus bassanus & 0.3 & 0.3 & 0.3 & 0.3 & 0.2 & 0.2 & 1.5 \\
\hline Germany & DE2X & 720 & Phalacrocorax carbo & 0.0 & 0.0 & 0.0 & 0.0 & 0.0 & 0.0 & 0.0 \\
\hline Germany & DE2X & 2060 & Somoteria mollissima & 0.0 & 0.0 & 0.0 & 0.0 & 0.0 & 0.0 & 0.0 \\
\hline Germany & DE2X & 6110 & Thalasseus sandvicensis & 0.0 & 0.0 & 0.0 & 0.0 & 0.0 & 0.0 & 0.0 \\
\hline Germany & DE2X & 6340 & Uria aalge & 4.7 & 3.8 & 20.6 & 3.1 & 0.7 & 3.8 & 36.7 \\
\hline Germany & DE2Z & 6360 & Alca torda & 0.0 & 0.2 & 0.0 & 0.2 & 0.0 & 0.0 & 0.4 \\
\hline Germany & DE2Z & 6540 & Fratercula arctica & 0.0 & 0.0 & 0.5 & 0.0 & 0.0 & 0.0 & 0.5 \\
\hline Germany & DE2Z & 220 & Fulmarus glacialis & 0.1 & 0.1 & 0.2 & 0.1 & 0.1 & 0.1 & 0.7 \\
\hline Germany & DE2Z & 59 & Gavia sp & 0.0 & 0.0 & 0.0 & 0.0 & 0.0 & 0.0 & 0.0 \\
\hline Germany & DE2Z & 2130 & Melanitta nigra & 0.0 & 0.0 & 0.0 & 0.0 & 0.0 & 0.0 & 0.0 \\
\hline Germany & DE2Z & 710 & Morus bassanus & 0.1 & 0.0 & 0.5 & 0.0 & 0.0 & 0.1 & 0.8 \\
\hline Germany & DE2Z & 720 & Phalacrocorax carbo & 0.0 & 0.0 & 0.0 & 0.0 & 0.0 & 0.0 & 0.0 \\
\hline Germany & DE2Z & 2060 & Somoteria mollissima & 0.0 & 0.0 & 0.0 & 0.0 & 0.0 & 0.0 & 0.0 \\
\hline Germany & DE2Z & 6110 & Thalasseus sandvicensis & 0.0 & 0.0 & 0.0 & 0.0 & 0.0 & 0.0 & 0.0 \\
\hline Germany & DE2Z & 6340 & Uria aalge & 3.4 & 0.5 & 0.4 & 0.4 & 0.4 & 3.4 & 8.5 \\
\hline Germany & DE30 & 6360 & Alca torda & 0.0 & 1.2 & 0.6 & 0.2 & 0.0 & 0.0 & 2.0 \\
\hline Germany & DE30 & 6540 & Fratercula arctica & 0.0 & 0.0 & 0.0 & 0.0 & 0.0 & 0.0 & 0.0 \\
\hline Germany & DE30 & 220 & Fulmarus glacialis & 0.0 & 0.1 & 0.0 & 0.0 & 0.1 & 0.1 & 0.2 \\
\hline Germany & DE30 & 59 & Gavia sp & 0.0 & 0.1 & 0.0 & 0.4 & 3.8 & 0.0 & 4.3 \\
\hline Germany & DE30 & 2130 & Melanitta nigra & 0.0 & 0.0 & 0.0 & 0.0 & 0.0 & 0.0 & 0.0 \\
\hline Germany & DE30 & 710 & Morus bassanus & 0.3 & 0.2 & 0.1 & 0.1 & 0.1 & 0.1 & 0.9 \\
\hline Germany & DE30 & 720 & Phalacrocorax carbo & 0.0 & 0.0 & 0.0 & 0.0 & 0.0 & 0.0 & 0.0 \\
\hline Germany & DE30 & 2060 & Somoteria mollissima & 0.0 & 0.0 & 0.0 & 0.0 & 0.0 & 0.0 & 0.0 \\
\hline Germany & DE30 & 6110 & Thalasseus sandvicensis & 0.1 & 0.0 & 0.0 & 0.0 & 0.2 & 0.1 & 0.3 \\
\hline Germany & DE30 & 6340 & Uria aalge & 0.0 & 3.7 & 3.4 & 1.3 & 0.7 & 0.0 & 9.1 \\
\hline Germany & DE33 & 6360 & Alca torda & 0.0 & 0.0 & 0.0 & 0.0 & 0.0 & 0.0 & 0.0 \\
\hline Germany & DE33 & 6540 & Fratercula arctica & 0.0 & 0.0 & 0.0 & 0.0 & 0.0 & 0.0 & 0.0 \\
\hline Germany & DE33 & 220 & Fulmarus glacialis & 0.0 & 0.0 & 0.0 & 0.1 & 0.1 & 0.0 & 0.3 \\
\hline Germany & DE33 & 59 & Gavia sp & 0.0 & 0.2 & 12.4 & 0.1 & 0.4 & 0.0 & 13.2 \\
\hline Germany & DE33 & 2130 & Melanitta nigra & 0.0 & 0.0 & 0.0 & 0.0 & 0.0 & 0.0 & 0.0 \\
\hline Germany & DE33 & 710 & Morus bassanus & 0.1 & 0.0 & 0.0 & 0.1 & 0.1 & 0.1 & 0.5 \\
\hline Germany & DE33 & 720 & Phalacrocorax carbo & 0.0 & 0.0 & 0.0 & 0.0 & 0.0 & 0.0 & 0.0 \\
\hline Germany & DE33 & 2060 & Somoteria mollissima & 0.0 & 0.0 & 0.0 & 0.0 & 0.0 & 0.0 & 0.0 \\
\hline Germany & DE33 & 6110 & Thalasseus sandvicensis & 0.0 & 0.0 & 0.0 & 0.0 & 0.1 & 0.0 & 0.1 \\
\hline Germany & DE33 & 6340 & Uria aalge & 0.0 & 0.4 & 0.8 & 0.1 & 0.2 & 0.1 & 1.7 \\
\hline Germany & DE36 & 6360 & Alca torda & 0.1 & 0.2 & 0.3 & 0.1 & 0.0 & 0.0 & 0.7 \\
\hline Germany & DE36 & 6540 & Fratercula arctica & 0.0 & 0.0 & 0.0 & 0.0 & 0.0 & 0.0 & 0.0 \\
\hline
\end{tabular}




\begin{tabular}{|c|c|c|c|c|c|c|c|c|c|c|}
\hline CountryName & UniekID & EUring & species & Aug + Sep & Okt + Nov & Dec + Jan & Feb + Mar & Apr + May & Jun + Jul & Total \\
\hline Germany & DE36 & 220 & Fulmarus glacialis & 0.1 & 0.1 & 0.1 & 0.0 & 0.0 & 0.1 & 0.5 \\
\hline Germany & DE36 & 59 & Gavia sp & 0.0 & 0.3 & 0.0 & 0.0 & 0.0 & 0.0 & 0.4 \\
\hline Germany & DE36 & 2130 & Melanitta nigra & 0.0 & 0.0 & 0.0 & 0.0 & 0.0 & 0.0 & 0.0 \\
\hline Germany & DE36 & 710 & Morus bassanus & 0.2 & 0.1 & 0.0 & 0.1 & 0.0 & 0.1 & 0.5 \\
\hline Germany & DE36 & 720 & Phalacrocorax carbo & 0.0 & 0.0 & 0.0 & 0.0 & 0.0 & 0.0 & 0.0 \\
\hline Germany & DE36 & 2060 & Somoteria mollissima & 0.0 & 0.0 & 0.0 & 0.0 & 0.0 & 0.0 & 0.0 \\
\hline Germany & DE36 & 6110 & Thalasseus sandvicensis & 0.0 & 0.0 & 0.0 & 0.0 & 0.1 & 0.0 & 0.1 \\
\hline Germany & DE36 & 6340 & Uria aalge & 4.4 & 1.4 & 1.0 & 1.1 & 4.0 & 1.4 & 13.2 \\
\hline Germany & DE39 & 6360 & Alca torda & 0.0 & 0.2 & 0.0 & 0.0 & 0.0 & 0.0 & 0.2 \\
\hline Germany & DE39 & 6540 & Fratercula arctica & 0.0 & 0.0 & 0.2 & 0.0 & 0.0 & 0.0 & 0.2 \\
\hline Germany & DE39 & 220 & Fulmarus glacialis & 0.0 & 0.0 & 0.1 & 0.0 & 0.1 & 0.0 & 0.3 \\
\hline Germany & DE39 & 59 & Gavia sp & 0.0 & 0.0 & 0.0 & 0.0 & 0.0 & 0.0 & 0.0 \\
\hline Germany & DE39 & 2130 & Melanitta nigra & 0.0 & 0.0 & 0.0 & 0.0 & 0.0 & 0.0 & 0.0 \\
\hline Germany & DE39 & 710 & Morus bassanus & 0.0 & 0.0 & 0.2 & 0.0 & 0.1 & 0.0 & 0.4 \\
\hline Germany & DE39 & 720 & Phalacrocorax carbo & 0.0 & 0.0 & 0.0 & 0.0 & 0.0 & 0.0 & 0.0 \\
\hline Germany & DE39 & 2060 & Somoteria mollissima & 0.0 & 0.0 & 0.0 & 0.0 & 0.0 & 0.0 & 0.0 \\
\hline Germany & DE39 & 6110 & Thalasseus sandvicensis & 0.0 & 0.0 & 0.0 & 0.0 & 0.0 & 0.0 & 0.0 \\
\hline Germany & DE39 & 6340 & Uria aalge & 0.8 & 0.3 & 0.2 & 0.0 & 0.4 & 1.5 & 3.1 \\
\hline Germany & DE3A & 6360 & Alca torda & 0.0 & 0.2 & 1.1 & 0.2 & 0.0 & 0.0 & 1.6 \\
\hline Germany & DE3A & 6540 & Fratercula arctica & 0.0 & 0.0 & 0.1 & 0.0 & 0.0 & 0.0 & 0.1 \\
\hline Germany & DE3A & 220 & Fulmarus glacialis & 0.3 & 0.1 & 0.6 & 0.1 & 0.1 & 0.2 & 1.4 \\
\hline Germany & DE3A & 59 & Gavia sp & 0.0 & 0.0 & 0.0 & 1.6 & 0.0 & 0.0 & 1.6 \\
\hline Germany & DE3A & 2130 & Melanitta nigra & 0.0 & 0.0 & 0.0 & 0.0 & 0.0 & 0.0 & 0.0 \\
\hline Germany & DE3A & 710 & Morus bassanus & 0.2 & 0.1 & 0.0 & 0.0 & 0.1 & 0.3 & 0.7 \\
\hline Germany & DE3A & 720 & Phalacrocorax carbo & 0.0 & 0.0 & 0.0 & 0.0 & 0.0 & 0.0 & 0.0 \\
\hline Germany & DE3A & 2060 & Somoteria mollissima & 0.0 & 0.0 & 0.0 & 0.0 & 0.0 & 0.0 & 0.0 \\
\hline Germany & DE3A & 6110 & Thalasseus sandvicensis & 0.0 & 0.0 & 0.0 & 0.0 & 0.0 & 0.0 & 0.0 \\
\hline Germany & DE3A & 6340 & Uria aalge & 3.2 & 1.8 & 3.1 & 0.9 & 3.7 & 2.5 & 15.3 \\
\hline Germany & DE3B & 6360 & Alca torda & 0.0 & 0.1 & 1.0 & 0.3 & 0.0 & 0.0 & 1.4 \\
\hline Germany & DE3B & 6540 & Fratercula arctica & 0.0 & 0.0 & 0.1 & 0.0 & 0.0 & 0.0 & 0.1 \\
\hline Germany & DE3B & 220 & Fulmarus glacialis & 0.4 & 0.2 & 0.7 & 0.1 & 0.4 & 0.2 & 1.9 \\
\hline Germany & DE3B & 59 & Gavia sp & 0.0 & 0.0 & 0.0 & 1.8 & 0.0 & 0.0 & 1.8 \\
\hline Germany & DE3B & 2130 & Melanitta nigra & 0.0 & 0.0 & 0.0 & 0.0 & 0.0 & 0.0 & 0.0 \\
\hline Germany & DE3B & 710 & Morus bassanus & 0.1 & 0.2 & 0.1 & 0.0 & 0.1 & 0.3 & 0.7 \\
\hline Germany & DE3B & 720 & Phalacrocorax carbo & 0.0 & 0.0 & 0.0 & 0.0 & 0.0 & 0.0 & 0.0 \\
\hline Germany & DE3B & 2060 & Somoteria mollissima & 0.0 & 0.0 & 0.0 & 0.0 & 0.0 & 0.0 & 0.0 \\
\hline Germany & DE3B & 6110 & Thalasseus sandvicensis & 0.0 & 0.0 & 0.0 & 0.0 & 0.0 & 0.0 & 0.0 \\
\hline Germany & DE3B & 6340 & Uria aalge & 4.1 & 1.8 & 2.3 & 1.1 & 0.7 & 2.9 & 13.0 \\
\hline Germany & DE3C & 6360 & Alca torda & 0.0 & 0.0 & 0.2 & 0.1 & 0.0 & 0.0 & 0.4 \\
\hline Germany & DE3C & 6540 & Fratercula arctica & 0.0 & 0.0 & 1.0 & 0.0 & 0.0 & 0.0 & 1.0 \\
\hline Germany & DE3C & 220 & Fulmarus glacialis & 0.3 & 0.2 & 0.5 & 0.1 & 0.3 & 0.2 & 1.6 \\
\hline Germany & DE3C & 59 & Gavia sp & 0.0 & 0.0 & 0.0 & 0.0 & 0.0 & 0.0 & 0.0 \\
\hline Germany & DE3C & 2130 & Melanitta nigra & 0.0 & 0.0 & 0.0 & 0.0 & 0.0 & 0.0 & 0.0 \\
\hline Germany & DE3C & 710 & Morus bassanus & 0.1 & 0.2 & 0.9 & 0.1 & 0.0 & 0.2 & 1.6 \\
\hline Germany & DE3C & 720 & Phalacrocorax carbo & 0.0 & 0.0 & 0.0 & 0.0 & 0.0 & 0.0 & 0.0 \\
\hline Germany & DE3C & 2060 & Somoteria mollissima & 0.0 & 0.0 & 0.0 & 0.0 & 0.0 & 0.0 & 0.0 \\
\hline Germany & DE3C & 6110 & Thalasseus sandvicensis & 0.0 & 0.0 & 0.0 & 0.0 & 0.0 & 0.0 & 0.0 \\
\hline Germany & DE3C & 6340 & Uria aalge & 4.1 & 2.0 & 0.9 & 0.7 & 0.0 & 2.5 & 10.2 \\
\hline Germany & DE3I & 6360 & Alca torda & 0.0 & 0.1 & 0.2 & 0.0 & 0.0 & 0.0 & 0.3 \\
\hline Germany & DE3I & 6540 & Fratercula arctica & 0.0 & 0.0 & 0.3 & 0.0 & 0.0 & 0.0 & 0.4 \\
\hline Germany & DE3I & 220 & Fulmarus glacialis & 0.2 & 0.1 & 0.4 & 0.0 & 0.1 & 0.2 & 1.1 \\
\hline Germany & DE3I & 59 & Gavia sp & 0.0 & 0.0 & 0.2 & 0.0 & 0.0 & 0.0 & 0.2 \\
\hline Germany & DE3I & 2130 & Melanitta nigra & 0.0 & 0.0 & 0.0 & 0.0 & 0.0 & 0.0 & 0.0 \\
\hline Germany & DE3I & 710 & Morus bassanus & 0.1 & 0.1 & 0.2 & 0.0 & 0.0 & 0.2 & 0.6 \\
\hline Germany & DE3I & 720 & Phalacrocorax carbo & 0.0 & 0.0 & 0.0 & 0.0 & 0.0 & 0.0 & 0.0 \\
\hline Germany & DE3I & 2060 & Somoteria mollissima & 0.0 & 0.0 & 0.0 & 0.0 & 0.0 & 0.0 & 0.0 \\
\hline
\end{tabular}




\begin{tabular}{|c|c|c|c|c|c|c|c|c|c|c|}
\hline CountryName & UniekID & EUring & species & Aug + Sep & Okt + Nov & Dec + Jan & Feb + Mar & Apr + May & Jun + Jul & Total \\
\hline Germany & DE3I & 6110 & Thalasseus sandvicensis & 0.0 & 0.0 & 0.0 & 0.0 & 0.0 & 0.0 & 0.0 \\
\hline Germany & DE3I & 6340 & Uria aalge & 3.2 & 1.8 & 0.6 & 0.1 & 0.0 & 1.2 & 7.0 \\
\hline Germany & DE3R & 6360 & Alca torda & 0.0 & 0.4 & 0.2 & 0.3 & 0.0 & 0.0 & 1.0 \\
\hline Germany & DE3R & 6540 & Fratercula arctica & 0.0 & 0.0 & 0.0 & 0.0 & 0.1 & 0.0 & 0.2 \\
\hline Germany & DE3R & 220 & Fulmarus glacialis & 0.6 & 0.2 & 1.5 & 0.3 & 0.2 & 0.5 & 3.2 \\
\hline Germany & DE3R & 59 & Gavia sp & 0.0 & 0.0 & 0.1 & 0.1 & 0.3 & 0.0 & 0.4 \\
\hline Germany & DE3R & 2130 & Melanitta nigra & 0.0 & 0.0 & 0.0 & 0.0 & 0.1 & 0.0 & 0.1 \\
\hline Germany & DE3R & 710 & Morus bassanus & 0.7 & 0.0 & 0.0 & 0.2 & 0.3 & 0.6 & 1.9 \\
\hline Germany & DE3R & 720 & Phalacrocorax carbo & 0.0 & 0.0 & 0.0 & 0.0 & 0.0 & 0.0 & 0.0 \\
\hline Germany & DE3R & 2060 & Somoteria mollissima & 0.0 & 0.0 & 0.0 & 0.0 & 0.0 & 0.0 & 0.0 \\
\hline Germany & DE3R & 6110 & Thalasseus sandvicensis & 0.0 & 0.0 & 0.0 & 0.0 & 0.1 & 0.0 & 0.1 \\
\hline Germany & DE3R & 6340 & Uria aalge & 12.2 & 4.9 & 1.2 & 0.9 & 0.2 & 16.3 & 35.8 \\
\hline Germany & DE3S & 6360 & Alca torda & 0.0 & 0.4 & 0.9 & 0.6 & 0.0 & 0.0 & 1.9 \\
\hline Germany & DE3S & 6540 & Fratercula arctica & 0.0 & 0.0 & 0.1 & 0.0 & 0.0 & 0.0 & 0.1 \\
\hline Germany & DE3S & 220 & Fulmarus glacialis & 0.2 & 0.1 & 0.5 & 0.2 & 0.1 & 0.2 & 1.3 \\
\hline Germany & DE3S & 59 & Gavia sp & 0.0 & 0.0 & 0.0 & 0.3 & 0.0 & 0.0 & 0.3 \\
\hline Germany & DE3S & 2130 & Melanitta nigra & 0.0 & 0.0 & 0.0 & 0.0 & 0.0 & 0.0 & 0.0 \\
\hline Germany & DE3S & 710 & Morus bassanus & 0.1 & 0.1 & 0.0 & 0.0 & 0.1 & 0.3 & 0.6 \\
\hline Germany & DE3S & 720 & Phalacrocorax carbo & 0.0 & 0.0 & 0.0 & 0.0 & 0.0 & 0.0 & 0.0 \\
\hline Germany & DE3S & 2060 & Somoteria mollissima & 0.0 & 0.0 & 0.0 & 0.0 & 0.0 & 0.0 & 0.0 \\
\hline Germany & DE3S & 6110 & Thalasseus sandvicensis & 0.0 & 0.0 & 0.0 & 0.0 & 0.0 & 0.0 & 0.0 \\
\hline Germany & DE3S & 6340 & Uria aalge & 7.5 & 2.0 & 2.7 & 1.4 & 2.0 & 2.7 & 18.3 \\
\hline Germany & DE3T & 6360 & Alca torda & 0.0 & 0.2 & 0.7 & 0.4 & 0.0 & 0.0 & 1.3 \\
\hline Germany & DE3T & 6540 & Fratercula arctica & 0.0 & 0.0 & 0.0 & 0.0 & 0.0 & 0.0 & 0.0 \\
\hline Germany & DE3T & 220 & Fulmarus glacialis & 0.3 & 0.2 & 0.7 & 0.1 & 0.2 & 0.3 & 1.8 \\
\hline Germany & DE3T & 59 & Gavia sp & 0.0 & 0.0 & 0.2 & 1.4 & 0.0 & 0.0 & 1.6 \\
\hline Germany & DE3T & 2130 & Melanitta nigra & 0.0 & 0.0 & 0.0 & 0.0 & 0.0 & 0.0 & 0.0 \\
\hline Germany & DE3T & 710 & Morus bassanus & 0.3 & 0.2 & 0.0 & 0.0 & 0.0 & 0.4 & 0.9 \\
\hline Germany & DE3T & 720 & Phalacrocorax carbo & 0.0 & 0.0 & 0.0 & 0.0 & 0.0 & 0.0 & 0.0 \\
\hline Germany & DE3T & 2060 & Somoteria mollissima & 0.0 & 0.0 & 0.0 & 0.0 & 0.0 & 0.0 & 0.0 \\
\hline Germany & DE3T & 6110 & Thalasseus sandvicensis & 0.0 & 0.0 & 0.0 & 0.0 & 0.0 & 0.0 & 0.0 \\
\hline Germany & DE3T & 6340 & Uria aalge & 8.0 & 1.4 & 1.3 & 1.5 & 0.6 & 3.6 & 16.3 \\
\hline Netherlands & 1 & 6360 & Alca torda & 0.0 & 7.5 & 2.7 & 1.0 & 0.0 & 0.0 & 11.2 \\
\hline Netherlands & 1 & 6540 & Fratercula arctica & 0.0 & 0.0 & 0.2 & 0.0 & 0.0 & 0.0 & 0.2 \\
\hline Netherlands & 1 & 220 & Fulmarus glacialis & 0.0 & 0.1 & 0.2 & 0.1 & 0.1 & 0.0 & 0.4 \\
\hline Netherlands & 1 & 59 & Gavia sp & 0.0 & 0.1 & 0.5 & 0.4 & 0.1 & 0.0 & 1.1 \\
\hline Netherlands & 1 & 2130 & Melanitta nigra & 0.0 & 0.0 & 0.0 & 0.0 & 0.1 & 0.0 & 0.1 \\
\hline Netherlands & 1 & 710 & Morus bassanus & 0.2 & 0.7 & 0.6 & 0.6 & 0.2 & 0.4 & 2.7 \\
\hline Netherlands & 1 & 720 & Phalacrocorax carbo & 0.0 & 0.0 & 0.0 & 0.0 & 0.1 & 0.0 & 0.1 \\
\hline Netherlands & 1 & 2060 & Somoteria mollissima & 0.0 & 0.0 & 0.0 & 0.0 & 0.0 & 0.0 & 0.0 \\
\hline Netherlands & 1 & 6110 & Thalasseus sandvicensis & 0.1 & 0.0 & 0.0 & 0.0 & 0.9 & 0.4 & 1.5 \\
\hline Netherlands & 1 & 6340 & Uria aalge & 0.1 & 8.4 & 8.7 & 5.5 & 0.2 & 0.0 & 22.9 \\
\hline Netherlands & 2 & 6360 & Alca torda & 0.0 & 3.7 & 2.2 & 7.4 & 0.0 & 0.0 & 13.4 \\
\hline Netherlands & 2 & 6540 & Fratercula arctica & 0.0 & 0.0 & 0.2 & 0.0 & 0.0 & 0.0 & 0.2 \\
\hline Netherlands & 2 & 220 & Fulmarus glacialis & 0.0 & 0.1 & 0.2 & 0.1 & 0.1 & 0.0 & 0.5 \\
\hline Netherlands & 2 & 59 & Gavia sp & 0.0 & 0.1 & 0.4 & 0.1 & 0.0 & 0.0 & 0.6 \\
\hline Netherlands & 2 & 2130 & Melanitta nigra & 0.0 & 0.0 & 0.0 & 0.0 & 0.0 & 0.0 & 0.0 \\
\hline Netherlands & 2 & 710 & Morus bassanus & 0.2 & 0.8 & 0.7 & 0.8 & 0.2 & 0.1 & 2.8 \\
\hline Netherlands & 2 & 720 & Phalacrocorax carbo & 0.0 & 0.0 & 0.0 & 0.0 & 0.1 & 0.0 & 0.1 \\
\hline Netherlands & 2 & 2060 & Somoteria mollissima & 0.0 & 0.0 & 0.0 & 0.0 & 0.0 & 0.0 & 0.0 \\
\hline Netherlands & 2 & 6110 & Thalasseus sandvicensis & 0.0 & 0.0 & 0.0 & 0.0 & 0.5 & 0.5 & 1.0 \\
\hline Netherlands & 2 & 6340 & Uria aalge & 0.2 & 6.6 & 8.6 & 11.1 & 0.2 & 0.0 & 26.8 \\
\hline Netherlands & 3 & 6360 & Alca torda & 0.0 & 1.2 & 2.1 & 8.6 & 0.1 & 0.0 & 12.0 \\
\hline Netherlands & 3 & 6540 & Fratercula arctica & 0.0 & 0.0 & 0.0 & 0.0 & 0.0 & 0.0 & 0.0 \\
\hline Netherlands & 3 & 220 & Fulmarus glacialis & 0.0 & 0.3 & 0.3 & 0.3 & 0.1 & 0.0 & 1.0 \\
\hline Netherlands & 3 & 59 & Gavia sp & 0.0 & 0.1 & 0.1 & 0.1 & 0.0 & 0.1 & 0.3 \\
\hline
\end{tabular}




\begin{tabular}{|c|c|c|c|c|c|c|c|c|c|c|}
\hline CountryName & UniekID & EUring & species & Aug + Sep & Okt + Nov & Dec + Jan & Feb + Mar & Apr + May & Jun + Jul & Total \\
\hline Netherlands & 3 & 2130 & Melanitta nigra & 0.0 & 0.0 & 0.0 & 0.0 & 0.0 & 0.0 & 0.0 \\
\hline Netherlands & 3 & 710 & Morus bassanus & 0.1 & 0.8 & 0.8 & 1.2 & 0.2 & 0.1 & 3.2 \\
\hline Netherlands & 3 & 720 & Phalacrocorax carbo & 0.0 & 0.0 & 0.0 & 0.0 & 0.0 & 0.0 & 0.0 \\
\hline Netherlands & 3 & 2060 & Somoteria mollissima & 0.0 & 0.0 & 0.0 & 0.0 & 0.0 & 0.0 & 0.0 \\
\hline Netherlands & 3 & 6110 & Thalasseus sandvicensis & 0.0 & 0.0 & 0.0 & 0.0 & 0.1 & 0.1 & 0.2 \\
\hline Netherlands & 3 & 6340 & Uria aalge & 0.1 & 2.9 & 8.1 & 14.2 & 0.7 & 0.0 & 25.9 \\
\hline Netherlands & 4 & 6360 & Alca torda & 0.0 & 0.3 & 0.1 & 0.0 & 0.0 & 0.0 & 0.5 \\
\hline Netherlands & 4 & 6540 & Fratercula arctica & 0.0 & 0.0 & 0.0 & 0.0 & 0.0 & 0.0 & 0.0 \\
\hline Netherlands & 4 & 220 & Fulmarus glacialis & 0.0 & 0.0 & 0.0 & 0.0 & 0.0 & 0.0 & 0.0 \\
\hline Netherlands & 4 & 59 & Gavia sp & 0.0 & 0.0 & 0.0 & 0.0 & 0.0 & 0.0 & 0.0 \\
\hline Netherlands & 4 & 2130 & Melanitta nigra & 0.0 & 0.0 & 0.0 & 0.0 & 0.0 & 0.0 & 0.0 \\
\hline Netherlands & 4 & 710 & Morus bassanus & 0.0 & 0.0 & 0.1 & 0.0 & 0.0 & 0.0 & 0.2 \\
\hline Netherlands & 4 & 720 & Phalacrocorax carbo & 0.0 & 0.0 & 0.0 & 0.0 & 0.0 & 0.0 & 0.0 \\
\hline Netherlands & 4 & 2060 & Somoteria mollissima & 0.0 & 0.0 & 0.0 & 0.0 & 0.0 & 0.0 & 0.0 \\
\hline Netherlands & 4 & 6110 & Thalasseus sandvicensis & 0.0 & 0.0 & 0.0 & 0.0 & 0.0 & 0.0 & 0.0 \\
\hline Netherlands & 4 & 6340 & Uria aalge & 0.0 & 0.3 & 0.2 & 0.2 & 0.0 & 0.0 & 0.7 \\
\hline Netherlands & 5 & 6360 & Alca torda & 0.0 & 0.3 & 0.7 & 0.3 & 0.1 & 0.0 & 1.4 \\
\hline Netherlands & 5 & 6540 & Fratercula arctica & 0.0 & 0.0 & 0.0 & 0.0 & 0.0 & 0.0 & 0.0 \\
\hline Netherlands & 5 & 220 & Fulmarus glacialis & 0.0 & 0.0 & 0.0 & 0.0 & 0.0 & 0.0 & 0.0 \\
\hline Netherlands & 5 & 59 & Gavia sp & 0.0 & 0.2 & 0.5 & 0.1 & 0.1 & 0.0 & 0.8 \\
\hline Netherlands & 5 & 2130 & Melanitta nigra & 0.0 & 0.3 & 0.0 & 1.3 & 0.3 & 0.0 & 2.0 \\
\hline Netherlands & 5 & 710 & Morus bassanus & 0.1 & 0.1 & 0.1 & 0.1 & 0.0 & 0.1 & 0.4 \\
\hline Netherlands & 5 & 720 & Phalacrocorax carbo & 0.2 & 0.3 & 0.1 & 0.0 & 0.3 & 0.4 & 1.3 \\
\hline Netherlands & 5 & 2060 & Somoteria mollissima & 0.0 & 0.1 & 0.0 & 0.3 & 0.0 & 0.0 & 0.4 \\
\hline Netherlands & 5 & 6110 & Thalasseus sandvicensis & 0.2 & 0.0 & 0.0 & 0.0 & 0.2 & 0.4 & 0.7 \\
\hline Netherlands & 5 & 6340 & Uria aalge & 0.0 & 3.9 & 4.2 & 1.1 & 0.3 & 0.0 & 9.6 \\
\hline Netherlands & 6 & 6360 & Alca torda & 0.0 & 0.2 & 0.5 & 0.4 & 0.2 & 0.0 & 1.2 \\
\hline Netherlands & 6 & 6540 & Fratercula arctica & 0.0 & 0.0 & 0.0 & 0.0 & 0.0 & 0.0 & 0.0 \\
\hline Netherlands & 6 & 220 & Fulmarus glacialis & 0.0 & 0.0 & 0.0 & 0.0 & 0.0 & 0.0 & 0.1 \\
\hline Netherlands & 6 & 59 & Gavia sp & 0.0 & 0.0 & 0.1 & 0.0 & 0.1 & 0.0 & 0.2 \\
\hline Netherlands & 6 & 2130 & Melanitta nigra & 0.0 & 0.0 & 0.0 & 0.0 & 0.3 & 0.0 & 0.3 \\
\hline Netherlands & 6 & 710 & Morus bassanus & 0.0 & 0.1 & 0.0 & 0.1 & 0.0 & 0.0 & 0.3 \\
\hline Netherlands & 6 & 720 & Phalacrocorax carbo & 0.0 & 0.1 & 0.1 & 0.1 & 0.0 & 0.0 & 0.2 \\
\hline Netherlands & 6 & 2060 & Somoteria mollissima & 0.0 & 0.0 & 0.0 & 0.0 & 0.0 & 0.0 & 0.0 \\
\hline Netherlands & 6 & 6110 & Thalasseus sandvicensis & 0.0 & 0.0 & 0.0 & 0.0 & 0.1 & 0.0 & 0.1 \\
\hline Netherlands & 6 & 6340 & Uria aalge & 0.0 & 2.7 & 5.4 & 1.2 & 0.3 & 0.0 & 9.7 \\
\hline Netherlands & 7 & 6360 & Alca torda & 0.0 & 0.1 & 0.3 & 1.2 & 0.2 & 0.0 & 1.8 \\
\hline Netherlands & 7 & 6540 & Fratercula arctica & 0.0 & 0.0 & 0.0 & 0.0 & 0.0 & 0.0 & 0.0 \\
\hline Netherlands & 7 & 220 & Fulmarus glacialis & 0.0 & 0.0 & 0.0 & 0.0 & 0.0 & 0.0 & 0.0 \\
\hline Netherlands & 7 & 59 & Gavia sp & 0.0 & 0.0 & 0.0 & 0.2 & 0.0 & 0.0 & 0.2 \\
\hline Netherlands & 7 & 2130 & Melanitta nigra & 0.0 & 0.0 & 0.0 & 0.0 & 0.0 & 0.0 & 0.0 \\
\hline Netherlands & 7 & 710 & Morus bassanus & 0.1 & 0.0 & 0.0 & 0.0 & 0.1 & 0.0 & 0.3 \\
\hline Netherlands & 7 & 720 & Phalacrocorax carbo & 0.0 & 0.0 & 0.0 & 0.0 & 0.0 & 0.1 & 0.1 \\
\hline Netherlands & 7 & 2060 & Somoteria mollissima & 0.0 & 0.0 & 0.0 & 0.0 & 0.0 & 0.0 & 0.0 \\
\hline Netherlands & 7 & 6110 & Thalasseus sandvicensis & 0.0 & 0.0 & 0.0 & 0.0 & 0.0 & 0.1 & 0.2 \\
\hline Netherlands & 7 & 6340 & Uria aalge & 0.0 & 1.8 & 4.4 & 1.0 & 0.3 & 0.0 & 7.5 \\
\hline Netherlands & 8 & 6360 & Alca torda & 0.0 & 1.7 & 0.7 & 0.8 & 0.2 & 0.0 & 3.4 \\
\hline Netherlands & 8 & 6540 & Fratercula arctica & 0.0 & 0.0 & 0.0 & 0.0 & 0.0 & 0.0 & 0.0 \\
\hline Netherlands & 8 & 220 & Fulmarus glacialis & 0.2 & 0.1 & 0.1 & 0.0 & 0.0 & 0.1 & 0.5 \\
\hline Netherlands & 8 & 59 & Gavia sp & 0.0 & 0.0 & 0.0 & 0.2 & 0.1 & 0.0 & 0.3 \\
\hline Netherlands & 8 & 2130 & Melanitta nigra & 0.0 & 0.2 & 0.0 & 0.0 & 0.0 & 0.0 & 0.2 \\
\hline Netherlands & 8 & 710 & Morus bassanus & 0.3 & 0.1 & 0.0 & 0.0 & 0.1 & 0.1 & 0.6 \\
\hline Netherlands & 8 & 720 & Phalacrocorax carbo & 0.0 & 0.0 & 0.0 & 0.0 & 0.0 & 0.0 & 0.0 \\
\hline Netherlands & 8 & 2060 & Somoteria mollissima & 0.0 & 0.0 & 0.0 & 0.0 & 0.0 & 0.0 & 0.0 \\
\hline Netherlands & 8 & 6110 & Thalasseus sandvicensis & 0.1 & 0.0 & 0.0 & 0.0 & 0.0 & 0.0 & 0.1 \\
\hline Netherlands & 8 & 6340 & Uria aalge & 2.9 & 3.8 & 5.2 & 2.4 & 1.3 & 1.7 & 17.5 \\
\hline
\end{tabular}




\begin{tabular}{|c|c|c|c|c|c|c|c|c|c|c|}
\hline CountryName & UniekID & EUring & species & Aug + Sep & Okt + Nov & Dec + Jan & Feb + Mar & Apr + May & Jun + Jul & Total \\
\hline Netherlands & 9 & 6360 & Alca torda & 0.0 & 1.2 & 0.4 & 1.6 & 0.5 & 0.0 & 3.7 \\
\hline Netherlands & 9 & 6540 & Fratercula arctica & 0.0 & 0.0 & 0.0 & 0.0 & 0.0 & 0.0 & 0.0 \\
\hline Netherlands & 9 & 220 & Fulmarus glacialis & 0.0 & 0.1 & 0.0 & 0.0 & 0.1 & 0.1 & 0.3 \\
\hline Netherlands & 9 & 59 & Gavia sp & 0.0 & 0.0 & 0.0 & 0.0 & 0.5 & 0.0 & 0.5 \\
\hline Netherlands & 9 & 2130 & Melanitta nigra & 0.0 & 0.1 & 0.0 & 0.0 & 0.1 & 0.0 & 0.2 \\
\hline Netherlands & 9 & 710 & Morus bassanus & 0.1 & 0.0 & 0.0 & 0.0 & 0.2 & 0.1 & 0.4 \\
\hline Netherlands & 9 & 720 & Phalacrocorax carbo & 0.0 & 0.0 & 0.0 & 0.0 & 0.0 & 0.0 & 0.0 \\
\hline Netherlands & 9 & 2060 & Somoteria mollissima & 0.0 & 0.0 & 0.0 & 0.0 & 0.0 & 0.0 & 0.0 \\
\hline Netherlands & 9 & 6110 & Thalasseus sandvicensis & 0.0 & 0.0 & 0.0 & 0.0 & 0.2 & 0.0 & 0.3 \\
\hline Netherlands & 9 & 6340 & Uria aalge & 1.0 & 3.9 & 3.3 & 1.9 & 1.3 & 0.6 & 12.1 \\
\hline Netherlands & 10 & 6360 & Alca torda & 0.1 & 2.6 & 1.3 & 4.1 & 0.5 & 0.0 & 8.6 \\
\hline Netherlands & 10 & 6540 & Fratercula arctica & 0.0 & 0.0 & 0.0 & 0.0 & 0.0 & 0.0 & 0.0 \\
\hline Netherlands & 10 & 220 & Fulmarus glacialis & 0.0 & 0.0 & 0.1 & 0.1 & 0.0 & 0.0 & 0.2 \\
\hline Netherlands & 10 & 59 & Gavia sp & 0.0 & 0.0 & 0.6 & 1.0 & 0.1 & 0.0 & 1.8 \\
\hline Netherlands & 10 & 2130 & Melanitta nigra & 0.0 & 0.0 & 0.0 & 0.0 & 0.0 & 0.0 & 0.0 \\
\hline Netherlands & 10 & 710 & Morus bassanus & 0.2 & 0.3 & 0.1 & 0.1 & 0.4 & 0.1 & 1.1 \\
\hline Netherlands & 10 & 720 & Phalacrocorax carbo & 0.0 & 0.0 & 0.0 & 0.0 & 0.0 & 0.3 & 0.4 \\
\hline Netherlands & 10 & 2060 & Somoteria mollissima & 0.0 & 0.0 & 0.8 & 0.0 & 0.0 & 0.0 & 0.8 \\
\hline Netherlands & 10 & 6110 & Thalasseus sandvicensis & 0.3 & 0.0 & 0.0 & 0.0 & 0.8 & 0.2 & 1.4 \\
\hline Netherlands & 10 & 6340 & Uria aalge & 0.1 & 5.3 & 18.1 & 2.9 & 1.0 & 0.1 & 27.5 \\
\hline Netherlands & 11 & 6360 & Alca torda & 0.0 & 4.1 & 0.8 & 0.5 & 0.1 & 0.0 & 5.4 \\
\hline Netherlands & 11 & 6540 & Fratercula arctica & 0.0 & 0.0 & 0.0 & 0.0 & 0.0 & 0.0 & 0.0 \\
\hline Netherlands & 11 & 220 & Fulmarus glacialis & 0.0 & 0.0 & 0.0 & 0.0 & 0.0 & 0.0 & 0.1 \\
\hline Netherlands & 11 & 59 & Gavia sp & 0.0 & 0.0 & 0.0 & 0.0 & 0.0 & 0.0 & 0.0 \\
\hline Netherlands & 11 & 2130 & Melanitta nigra & 0.0 & 0.0 & 0.0 & 0.1 & 0.0 & 0.0 & 0.1 \\
\hline Netherlands & 11 & 710 & Morus bassanus & 0.1 & 0.2 & 0.3 & 0.0 & 0.0 & 0.0 & 0.6 \\
\hline Netherlands & 11 & 720 & Phalacrocorax carbo & 0.0 & 0.0 & 0.0 & 0.0 & 0.0 & 0.0 & 0.1 \\
\hline Netherlands & 11 & 2060 & Somoteria mollissima & 0.0 & 0.0 & 1.1 & 0.0 & 0.0 & 0.0 & 1.1 \\
\hline Netherlands & 11 & 6110 & Thalasseus sandvicensis & 0.4 & 0.0 & 0.0 & 0.0 & 0.7 & 0.0 & 1.1 \\
\hline Netherlands & 11 & 6340 & Uria aalge & 0.0 & 9.6 & 8.9 & 3.3 & 0.4 & 0.0 & 22.2 \\
\hline Netherlands & 12 & 6360 & Alca torda & 0.0 & 1.1 & 0.6 & 0.8 & 0.1 & 0.0 & 2.6 \\
\hline Netherlands & 12 & 6540 & Fratercula arctica & 0.0 & 0.0 & 0.0 & 0.0 & 0.0 & 0.0 & 0.0 \\
\hline Netherlands & 12 & 220 & Fulmarus glacialis & 0.0 & 0.0 & 0.0 & 0.0 & 0.0 & 0.0 & 0.1 \\
\hline Netherlands & 12 & 59 & Gavia sp & 0.0 & 0.0 & 0.0 & 0.0 & 0.0 & 0.0 & 0.0 \\
\hline Netherlands & 12 & 2130 & Melanitta nigra & 0.0 & 0.0 & 0.0 & 0.0 & 0.0 & 0.0 & 0.0 \\
\hline Netherlands & 12 & 710 & Morus bassanus & 0.1 & 0.3 & 0.2 & 0.1 & 0.1 & 0.0 & 0.7 \\
\hline Netherlands & 12 & 720 & Phalacrocorax carbo & 0.0 & 0.0 & 0.0 & 0.0 & 0.0 & 0.0 & 0.0 \\
\hline Netherlands & 12 & 2060 & Somoteria mollissima & 0.0 & 0.0 & 0.0 & 0.0 & 0.0 & 0.0 & 0.0 \\
\hline Netherlands & 12 & 6110 & Thalasseus sandvicensis & 0.0 & 0.0 & 0.0 & 0.0 & 0.7 & 0.0 & 0.8 \\
\hline Netherlands & 12 & 6340 & Uria aalge & 0.0 & 4.1 & 13.0 & 2.6 & 1.1 & 0.0 & 20.9 \\
\hline Netherlands & 13 & 6360 & Alca torda & 0.0 & 0.5 & 1.1 & 1.1 & 0.2 & 0.0 & 2.9 \\
\hline Netherlands & 13 & 6540 & Fratercula arctica & 0.0 & 0.0 & 0.0 & 0.0 & 0.0 & 0.0 & 0.0 \\
\hline Netherlands & 13 & 220 & Fulmarus glacialis & 0.0 & 0.0 & 0.0 & 0.1 & 0.0 & 0.0 & 0.2 \\
\hline Netherlands & 13 & 59 & Gavia sp & 0.0 & 0.0 & 0.2 & 0.2 & 0.2 & 0.0 & 0.6 \\
\hline Netherlands & 13 & 2130 & Melanitta nigra & 0.0 & 0.0 & 0.0 & 0.0 & 0.0 & 0.0 & 0.0 \\
\hline Netherlands & 13 & 710 & Morus bassanus & 0.2 & 0.3 & 0.1 & 0.1 & 0.3 & 0.1 & 1.0 \\
\hline Netherlands & 13 & 720 & Phalacrocorax carbo & 0.0 & 0.0 & 0.0 & 0.0 & 0.0 & 0.1 & 0.1 \\
\hline Netherlands & 13 & 2060 & Somoteria mollissima & 0.0 & 0.1 & 0.0 & 0.0 & 0.0 & 0.0 & 0.1 \\
\hline Netherlands & 13 & 6110 & Thalasseus sandvicensis & 0.2 & 0.0 & 0.0 & 0.0 & 0.4 & 0.1 & 0.7 \\
\hline Netherlands & 13 & 6340 & Uria aalge & 0.1 & 7.3 & 12.3 & 2.2 & 1.1 & 0.0 & 23.0 \\
\hline Netherlands & 14 & 6360 & Alca torda & 0.0 & 6.8 & 2.3 & 2.9 & 0.0 & 0.0 & 12.0 \\
\hline Netherlands & 14 & 6540 & Fratercula arctica & 0.0 & 0.0 & 0.0 & 0.0 & 0.0 & 0.0 & 0.1 \\
\hline Netherlands & 14 & 220 & Fulmarus glacialis & 0.0 & 0.1 & 0.3 & 0.2 & 0.1 & 0.0 & 0.6 \\
\hline Netherlands & 14 & 59 & Gavia sp & 0.0 & 0.1 & 0.1 & 0.3 & 0.1 & 0.0 & 0.6 \\
\hline Netherlands & 14 & 2130 & Melanitta nigra & 0.0 & 0.0 & 0.0 & 0.0 & 0.0 & 0.0 & 0.0 \\
\hline Netherlands & 14 & 710 & Morus bassanus & 0.1 & 0.8 & 0.7 & 0.9 & 0.1 & 0.2 & 2.9 \\
\hline
\end{tabular}




\begin{tabular}{|c|c|c|c|c|c|c|c|c|c|c|}
\hline CountryName & UniekID & EUring & species & Aug + Sep & Okt + Nov & Dec + Jan & Feb + Mar & Apr + May & Jun + Jul & Total \\
\hline Netherlands & 14 & 720 & Phalacrocorax carbo & 0.0 & 0.0 & 0.0 & 0.0 & 0.0 & 0.0 & 0.0 \\
\hline Netherlands & 14 & 2060 & Somoteria mollissima & 0.0 & 0.0 & 0.0 & 0.0 & 0.0 & 0.0 & 0.0 \\
\hline Netherlands & 14 & 6110 & Thalasseus sandvicensis & 0.1 & 0.0 & 0.0 & 0.0 & 0.9 & 0.0 & 1.0 \\
\hline Netherlands & 14 & 6340 & Uria aalge & 0.0 & 8.2 & 9.0 & 9.6 & 0.8 & 0.0 & 27.7 \\
\hline Netherlands & 15 & 6360 & Alca torda & 0.0 & 2.1 & 3.2 & 5.2 & 0.9 & 0.0 & 11.5 \\
\hline Netherlands & 15 & 6540 & Fratercula arctica & 0.0 & 0.1 & 0.0 & 0.1 & 0.0 & 0.0 & 0.1 \\
\hline Netherlands & 15 & 220 & Fulmarus glacialis & 0.1 & 0.0 & 0.0 & 0.1 & 0.1 & 0.0 & 0.4 \\
\hline Netherlands & 15 & 59 & Gavia sp & 0.0 & 0.1 & 0.2 & 1.0 & 0.3 & 0.0 & 1.6 \\
\hline Netherlands & 15 & 2130 & Melanitta nigra & 0.0 & 0.0 & 0.0 & 0.5 & 0.0 & 0.0 & 0.6 \\
\hline Netherlands & 15 & 710 & Morus bassanus & 0.3 & 0.7 & 0.8 & 0.5 & 0.3 & 0.3 & 2.9 \\
\hline Netherlands & 15 & 720 & Phalacrocorax carbo & 0.0 & 0.0 & 0.0 & 0.0 & 0.0 & 0.0 & 0.1 \\
\hline Netherlands & 15 & 2060 & Somoteria mollissima & 0.0 & 0.0 & 0.0 & 0.0 & 0.0 & 0.0 & 0.0 \\
\hline Netherlands & 15 & 6110 & Thalasseus sandvicensis & 0.3 & 0.0 & 0.0 & 0.0 & 0.7 & 0.7 & 1.8 \\
\hline Netherlands & 15 & 6340 & Uria aalge & 0.4 & 23.9 & 26.9 & 7.8 & 4.2 & 0.1 & 63.1 \\
\hline Netherlands & bw4 & 6360 & Alca torda & 0.0 & 2.7 & 1.9 & 1.8 & 0.2 & 0.0 & 6.5 \\
\hline Netherlands & bw4 & 6540 & Fratercula arctica & 0.0 & 0.0 & 0.1 & 0.0 & 0.0 & 0.0 & 0.1 \\
\hline Netherlands & bw4 & 220 & Fulmarus glacialis & 0.2 & 0.0 & 0.1 & 0.0 & 0.0 & 0.1 & 0.6 \\
\hline Netherlands & bw4 & 59 & Gavia sp & 0.0 & 0.0 & 0.0 & 0.2 & 0.5 & 0.0 & 0.7 \\
\hline Netherlands & bw4 & 2130 & Melanitta nigra & 0.0 & 0.2 & 0.0 & 0.0 & 0.0 & 0.0 & 0.3 \\
\hline Netherlands & bw4 & 710 & Morus bassanus & 0.3 & 0.2 & 0.0 & 0.1 & 0.1 & 0.2 & 0.9 \\
\hline Netherlands & bw4 & 720 & Phalacrocorax carbo & 0.0 & 0.0 & 0.0 & 0.0 & 0.0 & 0.0 & 0.0 \\
\hline Netherlands & bw4 & 2060 & Somoteria mollissima & 0.0 & 0.0 & 0.0 & 0.0 & 0.0 & 0.0 & 0.0 \\
\hline Netherlands & bw4 & 6110 & Thalasseus sandvicensis & 0.2 & 0.0 & 0.0 & 0.0 & 0.1 & 0.0 & 0.3 \\
\hline Netherlands & bw4 & 6340 & Uria aalge & 5.1 & 4.2 & 9.3 & 3.6 & 3.7 & 3.3 & 29.2 \\
\hline Netherlands & bw6 & 6360 & Alca torda & 0.1 & 6.7 & 15.3 & 30.0 & 0.6 & 0.0 & 52.7 \\
\hline Netherlands & bw6 & 6540 & Fratercula arctica & 0.0 & 0.1 & 0.1 & 0.8 & 0.0 & 0.0 & 1.0 \\
\hline Netherlands & bw6 & 220 & Fulmarus glacialis & 0.7 & 0.5 & 0.9 & 0.9 & 0.6 & 0.7 & 4.3 \\
\hline Netherlands & bw6 & 59 & Gavia sp & 0.0 & 0.1 & 0.5 & 0.0 & 0.1 & 0.0 & 0.7 \\
\hline Netherlands & bw6 & 2130 & Melanitta nigra & 0.0 & 0.6 & 0.0 & 0.0 & 0.0 & 0.0 & 0.6 \\
\hline Netherlands & bw6 & 710 & Morus bassanus & 0.9 & 2.3 & 1.2 & 0.5 & 1.2 & 0.2 & 6.3 \\
\hline Netherlands & bw6 & 720 & Phalacrocorax carbo & 0.0 & 0.0 & 0.0 & 0.0 & 0.0 & 0.0 & 0.0 \\
\hline Netherlands & bw6 & 2060 & Somoteria mollissima & 0.0 & 0.0 & 0.0 & 0.0 & 0.0 & 0.0 & 0.0 \\
\hline Netherlands & bw6 & 6110 & Thalasseus sandvicensis & 0.1 & 0.1 & 0.0 & 0.0 & 2.0 & 0.3 & 2.4 \\
\hline Netherlands & bw6 & 6340 & Uria aalge & 6.9 & 29.9 & 42.0 & 42.2 & 40.3 & 1.6 & 162.9 \\
\hline Netherlands & bw7 & 6360 & Alca torda & 0.0 & 1.6 & 4.8 & 11.6 & 0.0 & 0.0 & 18.0 \\
\hline Netherlands & bw7 & 6540 & Fratercula arctica & 0.0 & 0.0 & 0.0 & 0.1 & 0.0 & 0.0 & 0.1 \\
\hline Netherlands & bw7 & 220 & Fulmarus glacialis & 0.0 & 0.1 & 0.2 & 0.3 & 0.1 & 0.1 & 0.8 \\
\hline Netherlands & bw7 & 59 & Gavia sp & 0.0 & 0.0 & 0.2 & 0.0 & 0.0 & 0.0 & 0.2 \\
\hline Netherlands & bw7 & 2130 & Melanitta nigra & 0.0 & 0.0 & 0.0 & 0.0 & 0.0 & 0.0 & 0.0 \\
\hline Netherlands & bw7 & 710 & Morus bassanus & 0.2 & 0.6 & 0.6 & 0.4 & 0.5 & 0.1 & 2.2 \\
\hline Netherlands & bw7 & 720 & Phalacrocorax carbo & 0.0 & 0.0 & 0.0 & 0.0 & 0.0 & 0.0 & 0.0 \\
\hline Netherlands & bw7 & 2060 & Somoteria mollissima & 0.0 & 0.0 & 0.0 & 0.0 & 0.0 & 0.0 & 0.0 \\
\hline Netherlands & bw7 & 6110 & Thalasseus sandvicensis & 0.0 & 0.0 & 0.0 & 0.0 & 0.4 & 0.0 & 0.4 \\
\hline Netherlands & bw7 & 6340 & Uria aalge & 1.1 & 15.8 & 13.9 & 12.9 & 4.0 & 0.0 & 47.8 \\
\hline Netherlands & bw8 & 6360 & Alca torda & 0.0 & 0.9 & 2.7 & 8.2 & 0.0 & 0.0 & 11.8 \\
\hline Netherlands & bw8 & 6540 & Fratercula arctica & 0.0 & 0.0 & 0.1 & 0.1 & 0.0 & 0.0 & 0.1 \\
\hline Netherlands & bw8 & 220 & Fulmarus glacialis & 0.0 & 0.1 & 0.1 & 0.1 & 0.0 & 0.1 & 0.4 \\
\hline Netherlands & bw8 & 59 & Gavia sp & 0.0 & 0.1 & 0.0 & 0.0 & 0.0 & 0.0 & 0.1 \\
\hline Netherlands & bw8 & 2130 & Melanitta nigra & 0.0 & 0.0 & 0.0 & 0.0 & 0.0 & 0.0 & 0.0 \\
\hline Netherlands & bw8 & 710 & Morus bassanus & 0.1 & 0.3 & 0.2 & 0.1 & 0.2 & 0.0 & 1.0 \\
\hline Netherlands & bw8 & 720 & Phalacrocorax carbo & 0.0 & 0.0 & 0.0 & 0.0 & 0.0 & 0.0 & 0.0 \\
\hline Netherlands & bw8 & 2060 & Somoteria mollissima & 0.0 & 0.0 & 0.0 & 0.0 & 0.0 & 0.0 & 0.0 \\
\hline Netherlands & bw8 & 6110 & Thalasseus sandvicensis & 0.0 & 0.0 & 0.0 & 0.0 & 0.1 & 0.0 & 0.1 \\
\hline Netherlands & bw8 & 6340 & Uria aalge & 0.2 & 9.0 & 7.6 & 6.8 & 1.5 & 0.0 & 25.1 \\
\hline Netherlands & 258 & 6360 & Alca torda & 0.0 & 12.9 & 23.1 & 8.1 & 0.5 & 0.0 & 44.7 \\
\hline Netherlands & 258 & 6540 & Fratercula arctica & 0.0 & 0.2 & 0.3 & 0.7 & 0.5 & 0.0 & 1.6 \\
\hline
\end{tabular}




\begin{tabular}{|c|c|c|c|c|c|c|c|c|c|c|}
\hline CountryName & UniekID & EUring & species & Aug + Sep & Okt + Nov & Dec + Jan & $\mathrm{Feb}+\mathrm{Mar}$ & Apr + May & Jun + Jul & Total \\
\hline Netherlands & 258 & 220 & Fulmarus glacialis & 1.2 & 0.6 & 1.1 & 0.4 & 0.5 & 0.9 & 4.6 \\
\hline Netherlands & 258 & 59 & Gavia sp & 0.1 & 0.7 & 0.8 & 1.9 & 0.4 & 0.0 & 4.0 \\
\hline Netherlands & 258 & 2130 & Melanitta nigra & 0.0 & 2.5 & 0.0 & 0.0 & 0.0 & 0.0 & 2.5 \\
\hline Netherlands & 258 & 710 & Morus bassanus & 1.0 & 2.6 & 0.4 & 0.4 & 0.1 & 0.8 & 5.3 \\
\hline Netherlands & 258 & 720 & Phalacrocorax carbo & 0.0 & 0.0 & 0.0 & 0.0 & 0.0 & 0.0 & 0.0 \\
\hline Netherlands & 258 & 2060 & Somoteria mollissima & 0.0 & 0.0 & 0.0 & 0.0 & 0.0 & 0.0 & 0.0 \\
\hline Netherlands & 258 & 6110 & Thalasseus sandvicensis & 0.0 & 0.0 & 0.0 & 0.0 & 0.2 & 0.0 & 0.3 \\
\hline Netherlands & 258 & 6340 & Uria aalge & 28.7 & 47.2 & 128.5 & 23.8 & 30.9 & 14.0 & 273.1 \\
\hline Netherlands & $263 \mathrm{o}$ & 6360 & Alca torda & 0.3 & 8.0 & 4.4 & 2.3 & 0.3 & 0.0 & 15.4 \\
\hline Netherlands & 2630 & 6540 & Fratercula arctica & 0.0 & 0.1 & 0.2 & 0.1 & 0.3 & 0.0 & 0.7 \\
\hline Netherlands & 2630 & 220 & Fulmarus glacialis & 1.4 & 0.6 & 0.8 & 5.3 & 0.1 & 0.7 & 8.9 \\
\hline Netherlands & 2630 & 59 & Gavia sp & 0.0 & 0.8 & 0.4 & 0.7 & 0.3 & 0.0 & 2.2 \\
\hline Netherlands & 2630 & 2130 & Melanitta nigra & 0.0 & 0.0 & 0.0 & 0.0 & 0.0 & 0.0 & 0.0 \\
\hline Netherlands & $263 \mathrm{o}$ & 710 & Morus bassanus & 0.7 & 1.2 & 0.9 & 0.1 & 0.3 & 0.9 & 4.1 \\
\hline Netherlands & 2630 & 720 & Phalacrocorax carbo & 0.0 & 0.0 & 0.0 & 0.0 & 0.0 & 0.0 & 0.0 \\
\hline Netherlands & $263 \mathrm{o}$ & 2060 & Somoteria mollissima & 0.0 & 0.0 & 0.0 & 0.0 & 0.0 & 0.0 & 0.0 \\
\hline Netherlands & 2630 & 6110 & Thalasseus sandvicensis & 0.3 & 0.0 & 0.0 & 0.0 & 0.5 & 0.0 & 0.8 \\
\hline Netherlands & $263 \mathrm{o}$ & 6340 & Uria aalge & 39.2 & 11.2 & 19.0 & 8.4 & 6.3 & 20.8 & 104.9 \\
\hline Netherlands & 270 & 6360 & Alca torda & 0.0 & 5.6 & 11.9 & 16.8 & 0.5 & 0.0 & 34.6 \\
\hline Netherlands & 270 & 6540 & Fratercula arctica & 0.0 & 0.1 & 0.1 & 0.2 & 0.0 & 0.0 & 0.3 \\
\hline Netherlands & 270 & 220 & Fulmarus glacialis & 0.2 & 0.2 & 0.5 & 0.2 & 0.1 & 0.2 & 1.4 \\
\hline Netherlands & 270 & 59 & Gavia sp & 0.0 & 0.0 & 0.2 & 0.1 & 0.6 & 0.0 & 0.9 \\
\hline Netherlands & 270 & 2130 & Melanitta nigra & 0.0 & 0.0 & 0.0 & 0.0 & 0.0 & 0.0 & 0.0 \\
\hline Netherlands & 270 & 710 & Morus bassanus & 0.5 & 1.3 & 0.5 & 0.2 & 0.4 & 0.2 & 3.2 \\
\hline Netherlands & 270 & 720 & Phalacrocorax carbo & 0.0 & 0.0 & 0.0 & 0.1 & 0.0 & 0.0 & 0.1 \\
\hline Netherlands & 270 & 2060 & Somoteria mollissima & 0.0 & 0.0 & 0.0 & 0.0 & 0.0 & 0.0 & 0.0 \\
\hline Netherlands & 270 & 6110 & Thalasseus sandvicensis & 0.5 & 0.0 & 0.0 & 0.0 & 0.5 & 0.1 & 1.0 \\
\hline Netherlands & 270 & 6340 & Uria aalge & 8.1 & 29.7 & 31.8 & 22.4 & 25.5 & 0.6 & 118.0 \\
\hline Netherlands & 272 & 6360 & Alca torda & 0.0 & 4.1 & 9.7 & 4.7 & 0.3 & 0.0 & 19.0 \\
\hline Netherlands & 272 & 6540 & Fratercula arctica & 0.0 & 0.0 & 0.0 & 0.1 & 0.0 & 0.0 & 0.1 \\
\hline Netherlands & 272 & 220 & Fulmarus glacialis & 0.5 & 0.3 & 0.5 & 0.5 & 0.4 & 0.3 & 2.6 \\
\hline Netherlands & 272 & 59 & Gavia sp & 0.0 & 0.1 & 0.1 & 2.8 & 0.6 & 0.0 & 3.6 \\
\hline Netherlands & 272 & 2130 & Melanitta nigra & 0.0 & 0.2 & 0.0 & 0.0 & 0.0 & 0.0 & 0.2 \\
\hline Netherlands & 272 & 710 & Morus bassanus & 0.3 & 1.4 & 0.8 & 0.1 & 0.2 & 0.1 & 2.9 \\
\hline Netherlands & 272 & 720 & Phalacrocorax carbo & 0.0 & 0.0 & 0.0 & 0.0 & 0.0 & 0.0 & 0.0 \\
\hline Netherlands & 272 & 2060 & Somoteria mollissima & 0.0 & 0.0 & 0.0 & 0.0 & 0.0 & 0.0 & 0.0 \\
\hline Netherlands & 272 & 6110 & Thalasseus sandvicensis & 0.0 & 0.0 & 0.0 & 0.0 & 0.0 & 0.0 & 0.0 \\
\hline Netherlands & 272 & 6340 & Uria aalge & 6.6 & 20.5 & 29.9 & 8.0 & 17.2 & 0.8 & 83.0 \\
\hline Netherlands & 274 & 6360 & Alca torda & 0.2 & 38.3 & 12.2 & 10.5 & 5.6 & 0.0 & 66.8 \\
\hline Netherlands & 274 & 6540 & Fratercula arctica & 0.0 & 0.0 & 0.0 & 0.0 & 0.0 & 0.0 & 0.1 \\
\hline Netherlands & 274 & 220 & Fulmarus glacialis & 0.4 & 0.6 & 0.5 & 0.7 & 0.3 & 0.5 & 3.0 \\
\hline Netherlands & 274 & 59 & Gavia sp & 0.0 & 0.0 & 0.3 & 0.4 & 2.1 & 0.0 & 2.8 \\
\hline Netherlands & 274 & 2130 & Melanitta nigra & 0.0 & 0.0 & 0.0 & 0.0 & 0.0 & 0.0 & 0.0 \\
\hline Netherlands & 274 & 710 & Morus bassanus & 1.2 & 1.9 & 0.5 & 1.0 & 0.9 & 0.6 & 6.1 \\
\hline Netherlands & 274 & 720 & Phalacrocorax carbo & 0.0 & 0.0 & 0.0 & 0.0 & 0.0 & 0.0 & 0.0 \\
\hline Netherlands & 274 & 2060 & Somoteria mollissima & 0.0 & 0.0 & 0.0 & 0.0 & 0.0 & 0.0 & 0.0 \\
\hline Netherlands & 274 & 6110 & Thalasseus sandvicensis & 0.8 & 0.1 & 0.0 & 0.0 & 1.1 & 0.1 & 2.1 \\
\hline Netherlands & 274 & 6340 & Uria aalge & 22.3 & 30.7 & 49.4 & 27.0 & 38.6 & 4.4 & 172.4 \\
\hline United Kingdom & UK04 & 6360 & Alca torda & 0.4 & 0.5 & 0.3 & 0.2 & 0.2 & 1.6 & 3.2 \\
\hline United Kingdom & UK04 & 6540 & Fratercula arctica & 0.9 & 0.1 & 0.2 & 0.0 & 0.0 & 0.0 & 1.2 \\
\hline United Kingdom & UK04 & 220 & Fulmarus glacialis & 0.0 & 0.0 & 0.0 & 0.0 & 0.0 & 0.0 & 0.1 \\
\hline United Kingdom & UK04 & 59 & Gavia sp & 0.0 & 0.3 & 0.0 & 0.1 & 0.4 & 0.0 & 0.8 \\
\hline United Kingdom & UK04 & 2130 & Melanitta nigra & 0.0 & 1.0 & 0.0 & 0.0 & 0.0 & 0.0 & 1.0 \\
\hline United Kingdom & UK04 & 710 & Morus bassanus & 0.2 & 0.0 & 0.0 & 0.0 & 0.0 & 0.1 & 0.2 \\
\hline United Kingdom & UK04 & 720 & Phalacrocorax carbo & 0.0 & 0.0 & 0.0 & 0.0 & 0.0 & 0.0 & 0.0 \\
\hline United Kingdom & UK04 & 2060 & Somoteria mollissima & 0.0 & 0.0 & 0.0 & 0.0 & 0.0 & 0.0 & 0.0 \\
\hline
\end{tabular}




\begin{tabular}{|c|c|c|c|c|c|c|c|c|c|c|}
\hline $\begin{array}{l}\text { CountryName } \\
\end{array}$ & UniekID & EUring & species & $\mathrm{Aug}+\mathrm{Sep}$ & Okt + Nov & Dec + Jan & $\mathrm{Feb}+\mathrm{Mar}$ & Apr + May & Jun + Jul & Total \\
\hline United Kingdom & UK04 & 6110 & Thalasseus sandvicensis & 0.0 & 0.0 & 0.0 & 0.0 & 0.6 & 0.0 & 0.6 \\
\hline United Kingdom & UK04 & 6340 & Uria aalge & 29.5 & 4.6 & 0.5 & 3.7 & 4.6 & 5.7 & 48.6 \\
\hline United Kingdom & UK05 & 6360 & Alca torda & 0.0 & 0.1 & 4.4 & 1.9 & 0.0 & 0.0 & 6.4 \\
\hline United Kingdom & UK05 & 6540 & Fratercula arctica & 0.0 & 0.0 & 0.0 & 1.9 & 0.0 & 0.0 & 1.9 \\
\hline United Kingdom & UK05 & 220 & Fulmarus glacialis & 0.2 & 0.0 & 0.0 & 0.1 & 0.0 & 0.3 & 0.6 \\
\hline United Kingdom & UK05 & 59 & Gavia sp & 0.0 & 0.0 & 0.0 & 0.5 & 0.0 & 0.0 & 0.5 \\
\hline United Kingdom & UK05 & 2130 & Melanitta nigra & 0.0 & 0.0 & 0.0 & 0.0 & 0.0 & 0.0 & 0.0 \\
\hline United Kingdom & UK05 & 710 & Morus bassanus & 0.2 & 0.4 & 0.0 & 0.2 & 0.0 & 0.2 & 1.1 \\
\hline United Kingdom & UK05 & 720 & Phalacrocorax carbo & 0.0 & 0.0 & 0.0 & 0.0 & 0.0 & 0.0 & 0.0 \\
\hline United Kingdom & UK05 & 2060 & Somoteria mollissima & 0.0 & 0.0 & 0.0 & 0.0 & 0.0 & 0.0 & 0.0 \\
\hline United Kingdom & UK05 & 6110 & Thalasseus sandvicensis & 0.0 & 0.0 & 0.0 & 0.0 & 0.0 & 0.0 & 0.0 \\
\hline United Kingdom & UK05 & 6340 & Uria aalge & 0.0 & 0.6 & 4.1 & 9.3 & 0.4 & 1.6 & 16.1 \\
\hline United Kingdom & UK07 & 6360 & Alca torda & 0.0 & 0.0 & 0.0 & 0.0 & 0.1 & 0.0 & 0.1 \\
\hline United Kingdom & UK07 & 6540 & Fratercula arctica & 0.0 & 0.0 & 0.0 & 0.0 & 0.0 & 0.0 & 0.0 \\
\hline United Kingdom & UK07 & 220 & Fulmarus glacialis & 0.0 & 0.0 & 0.0 & 0.0 & 0.0 & 0.0 & 0.0 \\
\hline United Kingdom & UK07 & 59 & Gavia sp & 0.0 & 0.2 & 0.1 & 1.1 & 0.0 & 0.0 & 1.5 \\
\hline United Kingdom & UK07 & 2130 & Melanitta nigra & 0.0 & 0.0 & 0.0 & 0.0 & 0.0 & 0.0 & 0.0 \\
\hline United Kingdom & UK07 & 710 & Morus bassanus & 0.0 & 0.1 & 0.0 & 0.0 & 0.0 & 0.0 & 0.1 \\
\hline United Kingdom & UK07 & 720 & Phalacrocorax carbo & 0.0 & 0.0 & 0.0 & 0.0 & 0.0 & 0.0 & 0.0 \\
\hline United Kingdom & UK07 & 2060 & Somoteria mollissima & 0.0 & 0.0 & 0.0 & 0.0 & 0.0 & 0.0 & 0.0 \\
\hline United Kingdom & UK07 & 6110 & Thalasseus sandvicensis & 0.1 & 0.0 & 0.0 & 0.0 & 0.0 & 0.1 & 0.2 \\
\hline United Kingdom & UK07 & 6340 & Uria aalge & 0.0 & 0.1 & 1.6 & 0.0 & 0.2 & 0.0 & 1.9 \\
\hline United Kingdom & UKOV & 6360 & Alca torda & 0.0 & 25.1 & 5.1 & 226.2 & 38.6 & 60.0 & 355.1 \\
\hline United Kingdom & UKOV & 6540 & Fratercula arctica & 0.2 & 4.2 & 7.9 & 5.6 & 3.4 & 1.1 & 22.4 \\
\hline United Kingdom & UKOV & 220 & Fulmarus glacialis & 1.6 & 3.1 & 0.1 & 0.9 & 1.4 & 11.5 & 18.7 \\
\hline United Kingdom & UKOV & 59 & Gavia sp & 0.0 & 0.0 & 0.0 & 0.0 & 0.0 & 0.0 & 0.0 \\
\hline United Kingdom & UKOV & 2130 & Melanitta nigra & 0.0 & 0.0 & 0.0 & 0.0 & 0.0 & 0.0 & 0.0 \\
\hline United Kingdom & UKOV & 710 & Morus bassanus & 2.2 & 3.7 & 0.3 & 3.2 & 3.8 & 1.2 & 14.4 \\
\hline United Kingdom & UKOV & 720 & Phalacrocorax carbo & 0.0 & 0.0 & 0.0 & 0.0 & 0.0 & 0.0 & 0.0 \\
\hline United Kingdom & UKOV & 2060 & Somoteria mollissima & 2.1 & 0.0 & 0.0 & 0.0 & 0.0 & 0.0 & 2.1 \\
\hline United Kingdom & UKOV & 6110 & Thalasseus sandvicensis & 0.0 & 0.0 & 0.0 & 0.0 & 0.0 & 0.0 & 0.0 \\
\hline United Kingdom & UKOV & 6340 & Uria aalge & 29.7 & 314.9 & 47.3 & 467.2 & 129.6 & 144.1 & 1132.8 \\
\hline United Kingdom & UK10 & 6360 & Alca torda & 0.1 & 0.0 & 0.0 & 0.7 & 0.2 & 64.0 & 64.9 \\
\hline United Kingdom & UK10 & 6540 & Fratercula arctica & 0.0 & 0.0 & 0.0 & 0.1 & 0.1 & 0.5 & 0.9 \\
\hline United Kingdom & UK10 & 220 & Fulmarus glacialis & 0.0 & 0.0 & 0.0 & 0.0 & 0.0 & 0.0 & 0.1 \\
\hline United Kingdom & UK10 & 59 & Gavia sp & 0.0 & 0.3 & 0.0 & 0.1 & 0.0 & 0.0 & 0.4 \\
\hline United Kingdom & UK10 & 2130 & Melanitta nigra & 0.0 & 0.0 & 0.0 & 0.0 & 0.0 & 0.0 & 0.0 \\
\hline United Kingdom & UK10 & 710 & Morus bassanus & 0.1 & 0.0 & 0.0 & 0.0 & 0.0 & 0.6 & 0.7 \\
\hline United Kingdom & UK10 & 720 & Phalacrocorax carbo & 0.0 & 0.0 & 0.0 & 0.0 & 0.0 & 0.0 & 0.0 \\
\hline United Kingdom & UK10 & 2060 & Somoteria mollissima & 0.0 & 0.0 & 0.0 & 0.0 & 0.0 & 0.0 & 0.0 \\
\hline United Kingdom & UK10 & 6110 & Thalasseus sandvicensis & 0.0 & 0.0 & 0.0 & 0.0 & 0.2 & 0.0 & 0.2 \\
\hline United Kingdom & UK10 & 6340 & Uria aalge & 0.7 & 0.6 & 0.8 & 2.5 & 3.0 & 18.1 & 25.7 \\
\hline United Kingdom & UK11 & 6360 & Alca torda & 0.0 & 0.0 & 0.1 & 0.0 & 0.0 & 9.2 & 9.4 \\
\hline United Kingdom & UK11 & 6540 & Fratercula arctica & 0.0 & 0.0 & 0.0 & 0.0 & 0.0 & 0.1 & 0.2 \\
\hline United Kingdom & UK11 & 220 & Fulmarus glacialis & 0.0 & 0.0 & 0.0 & 0.0 & 0.0 & 0.0 & 0.0 \\
\hline United Kingdom & UK11 & 59 & Gavia sp & 0.0 & 0.1 & 0.0 & 0.4 & 0.0 & 0.0 & 0.5 \\
\hline United Kingdom & UK11 & 2130 & Melanitta nigra & 0.0 & 0.1 & 0.0 & 0.0 & 0.0 & 0.0 & 0.1 \\
\hline United Kingdom & UK11 & 710 & Morus bassanus & 0.0 & 0.0 & 0.0 & 0.0 & 0.0 & 0.3 & 0.3 \\
\hline United Kingdom & UK11 & 720 & Phalacrocorax carbo & 0.0 & 0.0 & 0.0 & 0.0 & 0.0 & 0.0 & 0.0 \\
\hline United Kingdom & UK11 & 2060 & Somoteria mollissima & 0.0 & 0.0 & 0.0 & 0.0 & 0.0 & 0.0 & 0.0 \\
\hline United Kingdom & UK11 & 6110 & Thalasseus sandvicensis & 0.0 & 0.0 & 0.0 & 0.0 & 0.2 & 0.0 & 0.2 \\
\hline United Kingdom & UK11 & 6340 & Uria aalge & 0.3 & 0.3 & 0.2 & 1.2 & 1.0 & 5.3 & 8.3 \\
\hline United Kingdom & UK12 & 6360 & Alca torda & 0.0 & 0.0 & 0.0 & 0.0 & 0.0 & 0.0 & 0.0 \\
\hline United Kingdom & UK12 & 6540 & Fratercula arctica & 0.0 & 0.0 & 0.0 & 0.0 & 0.0 & 0.0 & 0.0 \\
\hline United Kingdom & UK12 & 220 & Fulmarus glacialis & 0.0 & 0.0 & 0.0 & 0.0 & 0.0 & 0.0 & 0.0 \\
\hline United Kingdom & UK12 & 59 & Gavia sp & 0.0 & 0.2 & 0.9 & 0.5 & 0.1 & 0.0 & 1.7 \\
\hline
\end{tabular}




\begin{tabular}{|c|c|c|c|c|c|c|c|c|c|c|}
\hline CountryName & UniekID & EUring & species & Aug + Sep & Okt + Nov & Dec + Jan & Feb + Mar & Apr + May & Jun + Jul & Total \\
\hline United Kingdom & UK12 & 2130 & Melanitta nigra & 0.0 & 0.0 & 0.0 & 0.0 & 0.0 & 0.0 & 0.0 \\
\hline United Kingdom & UK12 & 710 & Morus bassanus & 0.0 & 0.0 & 0.0 & 0.0 & 0.0 & 0.0 & 0.1 \\
\hline United Kingdom & UK12 & 720 & Phalacrocorax carbo & 0.0 & 0.0 & 0.0 & 0.0 & 0.0 & 0.0 & 0.0 \\
\hline United Kingdom & UK12 & 2060 & Somoteria mollissima & 0.0 & 0.0 & 0.0 & 0.0 & 0.0 & 0.0 & 0.0 \\
\hline United Kingdom & UK12 & 6110 & Thalasseus sandvicensis & 0.1 & 0.0 & 0.0 & 0.0 & 0.0 & 0.1 & 0.2 \\
\hline United Kingdom & UK12 & 6340 & Uria aalge & 0.0 & 0.0 & 0.4 & 0.0 & 0.0 & 0.0 & 0.5 \\
\hline United Kingdom & UK13 & 6360 & Alca torda & 0.0 & 0.0 & 0.4 & 0.1 & 0.1 & 29.0 & 29.6 \\
\hline United Kingdom & UK13 & 6540 & Fratercula arctica & 0.0 & 0.2 & 0.0 & 0.0 & 0.1 & 0.2 & 0.5 \\
\hline United Kingdom & UK13 & 220 & Fulmarus glacialis & 0.0 & 0.0 & 0.0 & 0.0 & 0.0 & 0.1 & 0.1 \\
\hline United Kingdom & UK13 & 59 & Gavia sp & 0.0 & 0.2 & 0.1 & 1.4 & 0.0 & 0.0 & 1.7 \\
\hline United Kingdom & UK13 & 2130 & Melanitta nigra & 0.0 & 0.2 & 0.0 & 0.0 & 0.0 & 0.0 & 0.2 \\
\hline United Kingdom & UK13 & 710 & Morus bassanus & 0.0 & 0.0 & 0.0 & 0.0 & 0.0 & 1.0 & 1.0 \\
\hline United Kingdom & UK13 & 720 & Phalacrocorax carbo & 0.0 & 0.0 & 0.0 & 0.0 & 0.0 & 0.0 & 0.0 \\
\hline United Kingdom & UK13 & 2060 & Somoteria mollissima & 0.0 & 0.0 & 0.0 & 0.0 & 0.0 & 0.0 & 0.0 \\
\hline United Kingdom & UK13 & 6110 & Thalasseus sandvicensis & 0.0 & 0.0 & 0.0 & 0.0 & 0.6 & 0.0 & 0.6 \\
\hline United Kingdom & UK13 & 6340 & Uria aalge & 1.1 & 1.2 & 0.6 & 3.8 & 3.2 & 17.9 & 27.7 \\
\hline United Kingdom & UK14 & 6360 & Alca torda & 0.0 & 0.3 & 0.2 & 0.9 & 0.6 & 0.0 & 1.9 \\
\hline United Kingdom & UK14 & 6540 & Fratercula arctica & 0.0 & 0.0 & 0.0 & 0.1 & 0.0 & 0.0 & 0.1 \\
\hline United Kingdom & UK14 & 220 & Fulmarus glacialis & 0.0 & 0.1 & 0.0 & 0.0 & 0.1 & 0.2 & 0.4 \\
\hline United Kingdom & UK14 & 59 & Gavia sp & 0.0 & 0.9 & 0.2 & 6.5 & 0.2 & 0.0 & 7.9 \\
\hline United Kingdom & UK14 & 2130 & Melanitta nigra & 0.0 & 0.0 & 0.0 & 0.0 & 0.0 & 0.0 & 0.0 \\
\hline United Kingdom & UK14 & 710 & Morus bassanus & 0.0 & 0.7 & 0.0 & 0.0 & 0.1 & 0.2 & 1.1 \\
\hline United Kingdom & UK14 & 720 & Phalacrocorax carbo & 0.0 & 0.0 & 0.0 & 0.0 & 0.0 & 0.0 & 0.0 \\
\hline United Kingdom & UK14 & 2060 & Somoteria mollissima & 0.0 & 0.0 & 0.0 & 0.0 & 0.0 & 0.0 & 0.0 \\
\hline United Kingdom & UK14 & 6110 & Thalasseus sandvicensis & 0.2 & 0.0 & 0.0 & 0.0 & 0.0 & 0.4 & 0.6 \\
\hline United Kingdom & UK14 & 6340 & Uria aalge & 0.0 & 2.2 & 10.7 & 1.9 & 2.0 & 0.0 & 16.8 \\
\hline United Kingdom & UK15 & 6360 & Alca torda & 0.0 & 0.0 & 0.0 & 0.0 & 0.0 & 7.1 & 7.2 \\
\hline United Kingdom & UK15 & 6540 & Fratercula arctica & 0.0 & 0.0 & 0.0 & 0.0 & 0.0 & 0.0 & 0.1 \\
\hline United Kingdom & UK15 & 220 & Fulmarus glacialis & 0.0 & 0.0 & 0.0 & 0.0 & 0.0 & 0.0 & 0.0 \\
\hline United Kingdom & UK15 & 59 & Gavia sp & 0.0 & 0.0 & 0.0 & 0.4 & 0.0 & 0.0 & 0.4 \\
\hline United Kingdom & UK15 & 2130 & Melanitta nigra & 0.0 & 0.1 & 0.0 & 0.0 & 0.0 & 0.0 & 0.1 \\
\hline United Kingdom & UK15 & 710 & Morus bassanus & 0.0 & 0.0 & 0.0 & 0.0 & 0.0 & 0.3 & 0.3 \\
\hline United Kingdom & UK15 & 720 & Phalacrocorax carbo & 0.0 & 0.0 & 0.0 & 0.0 & 0.0 & 0.0 & 0.0 \\
\hline United Kingdom & UK15 & 2060 & Somoteria mollissima & 0.0 & 0.0 & 0.0 & 0.0 & 0.0 & 0.0 & 0.0 \\
\hline United Kingdom & UK15 & 6110 & Thalasseus sandvicensis & 0.0 & 0.0 & 0.0 & 0.0 & 0.1 & 0.0 & 0.2 \\
\hline United Kingdom & UK15 & 6340 & Uria aalge & 0.3 & 0.3 & 0.0 & 0.9 & 0.8 & 4.4 & 6.8 \\
\hline United Kingdom & UK18 & 6360 & Alca torda & 0.1 & 0.1 & 2.2 & 0.0 & 0.0 & 6.2 & 8.7 \\
\hline United Kingdom & UK18 & 6540 & Fratercula arctica & 0.0 & 0.2 & 0.9 & 0.0 & 0.1 & 0.0 & 1.3 \\
\hline United Kingdom & UK18 & 220 & Fulmarus glacialis & 0.1 & 0.0 & 0.0 & 0.0 & 0.1 & 0.0 & 0.2 \\
\hline United Kingdom & UK18 & 59 & Gavia sp & 0.0 & 0.1 & 0.0 & 6.5 & 0.0 & 0.0 & 6.7 \\
\hline United Kingdom & UK18 & 2130 & Melanitta nigra & 0.0 & 0.3 & 0.0 & 0.0 & 0.0 & 0.0 & 0.3 \\
\hline United Kingdom & UK18 & 710 & Morus bassanus & 0.0 & 0.0 & 0.0 & 0.0 & 0.0 & 0.3 & 0.3 \\
\hline United Kingdom & UK18 & 720 & Phalacrocorax carbo & 0.0 & 0.0 & 0.0 & 0.0 & 0.0 & 0.0 & 0.0 \\
\hline United Kingdom & UK18 & 2060 & Somoteria mollissima & 0.0 & 0.0 & 0.0 & 0.0 & 0.0 & 0.0 & 0.0 \\
\hline United Kingdom & UK18 & 6110 & Thalasseus sandvicensis & 0.0 & 0.0 & 0.0 & 0.0 & 1.0 & 0.0 & 1.0 \\
\hline United Kingdom & UK18 & 6340 & Uria aalge & 5.9 & 1.7 & 3.0 & 3.5 & 3.7 & 8.1 & 25.9 \\
\hline United Kingdom & UK1F & 6360 & Alca torda & 0.0 & 11.1 & 23.5 & 24.2 & 8.2 & 1.0 & 68.0 \\
\hline United Kingdom & UK1F & 6540 & Fratercula arctica & 0.6 & 3.3 & 0.2 & 0.8 & 4.6 & 0.2 & 9.7 \\
\hline United Kingdom & UK1F & 220 & Fulmarus glacialis & 1.3 & 1.3 & 1.5 & 1.1 & 2.6 & 1.5 & 9.2 \\
\hline United Kingdom & UK1F & 59 & Gavia sp & 0.0 & 0.0 & 0.0 & 0.0 & 0.0 & 0.0 & 0.0 \\
\hline United Kingdom & UK1F & 2130 & Melanitta nigra & 0.0 & 0.0 & 0.0 & 0.0 & 0.0 & 0.0 & 0.0 \\
\hline United Kingdom & UK1F & 710 & Morus bassanus & 1.9 & 2.3 & 0.6 & 0.9 & 3.1 & 1.0 & 9.7 \\
\hline United Kingdom & UK1F & 720 & Phalacrocorax carbo & 0.0 & 0.0 & 0.0 & 0.0 & 0.0 & 0.0 & 0.0 \\
\hline United Kingdom & UK1F & 2060 & Somoteria mollissima & 0.0 & 0.0 & 0.0 & 0.0 & 0.0 & 0.0 & 0.0 \\
\hline United Kingdom & UK1F & 6110 & Thalasseus sandvicensis & 0.0 & 0.0 & 0.0 & 0.0 & 0.0 & 0.0 & 0.0 \\
\hline United Kingdom & UK1F & 6340 & Uria aalge & 10.9 & 128.2 & 105.8 & 97.4 & 146.2 & 20.5 & 508.9 \\
\hline
\end{tabular}




\begin{tabular}{|c|c|c|c|c|c|c|c|c|c|c|}
\hline $\begin{array}{l}\text { CountryName } \\
\end{array}$ & UniekID & EUring & species & $\mathrm{Aug}+\mathrm{Sep}$ & Okt + Nov & Dec + Jan & $\mathrm{Feb}+\mathrm{Mar}$ & Apr + May & Jun + Jul & Total \\
\hline United Kingdom & UK1G & 6360 & Alca torda & 0.0 & 3.2 & 0.1 & 31.6 & 1.5 & 0.8 & 37.2 \\
\hline United Kingdom & UK1G & 6540 & Fratercula arctica & 0.1 & 0.5 & 0.8 & 2.8 & 0.1 & 0.0 & 4.4 \\
\hline United Kingdom & UK1G & 220 & Fulmarus glacialis & 0.3 & 0.2 & 0.1 & 0.1 & 0.6 & 0.5 & 1.8 \\
\hline United Kingdom & UK1G & 59 & Gavia sp & 0.0 & 0.0 & 0.0 & 0.0 & 0.0 & 0.0 & 0.0 \\
\hline United Kingdom & UK1G & 2130 & Melanitta nigra & 0.0 & 5.2 & 0.0 & 0.0 & 0.0 & 0.0 & 5.2 \\
\hline United Kingdom & UK1G & 710 & Morus bassanus & 0.5 & 1.1 & 0.1 & 0.8 & 0.8 & 0.4 & 3.6 \\
\hline United Kingdom & UK1G & 720 & Phalacrocorax carbo & 0.0 & 0.0 & 0.0 & 0.0 & 0.0 & 0.0 & 0.0 \\
\hline United Kingdom & UK1G & 2060 & Somoteria mollissima & 0.0 & 0.0 & 0.0 & 0.0 & 0.0 & 0.0 & 0.0 \\
\hline United Kingdom & UK1G & 6110 & Thalasseus sandvicensis & 0.0 & 0.0 & 0.0 & 0.0 & 0.0 & 0.0 & 0.0 \\
\hline United Kingdom & UK1G & 6340 & Uria aalge & 1.3 & 163.8 & 7.8 & 100.3 & 26.4 & 6.9 & 306.5 \\
\hline United Kingdom & UK1K & 6360 & Alca torda & 1.8 & 0.5 & 18.1 & 6.7 & 0.2 & 1.8 & 29.0 \\
\hline United Kingdom & UK1K & 6540 & Fratercula arctica & 0.4 & 0.0 & 1.6 & 0.1 & 0.3 & 0.2 & 2.5 \\
\hline United Kingdom & UK1K & 220 & Fulmarus glacialis & 1.0 & 1.0 & 3.7 & 1.7 & 1.2 & 1.2 & 9.7 \\
\hline United Kingdom & UK1K & 59 & Gavia sp & 0.0 & 0.0 & 0.0 & 0.0 & 0.0 & 0.0 & 0.0 \\
\hline United Kingdom & UK1K & 2130 & Melanitta nigra & 0.2 & 0.0 & 0.0 & 0.0 & 0.0 & 0.0 & 0.2 \\
\hline United Kingdom & UK1K & 710 & Morus bassanus & 1.7 & 1.0 & 2.0 & 1.0 & 0.1 & 1.0 & 6.9 \\
\hline United Kingdom & UK1K & 720 & Phalacrocorax carbo & 0.0 & 0.0 & 0.0 & 0.0 & 0.0 & 0.0 & 0.0 \\
\hline United Kingdom & UK1K & 2060 & Somoteria mollissima & 0.0 & 0.0 & 0.0 & 0.0 & 0.0 & 0.0 & 0.0 \\
\hline United Kingdom & UK1K & 6110 & Thalasseus sandvicensis & 0.0 & 0.0 & 0.0 & 0.0 & 0.0 & 0.0 & 0.0 \\
\hline United Kingdom & UK1K & 6340 & Uria aalge & 44.0 & 10.3 & 79.4 & 35.9 & 18.2 & 55.2 & 243.1 \\
\hline United Kingdom & UK1U & 6360 & Alca torda & 9.1 & 6.1 & 15.8 & 12.6 & 3.4 & 34.1 & 81.1 \\
\hline United Kingdom & UK1U & 6540 & Fratercula arctica & 5.0 & 1.6 & 0.1 & 1.2 & 0.4 & 5.4 & 13.7 \\
\hline United Kingdom & UK1U & 220 & Fulmarus glacialis & 2.6 & 1.7 & 0.2 & 0.6 & 2.1 & 1.2 & 8.4 \\
\hline United Kingdom & UK1U & 59 & Gavia sp & 0.0 & 0.0 & 0.0 & 0.0 & 0.0 & 0.0 & 0.0 \\
\hline United Kingdom & UK1U & 2130 & Melanitta nigra & 0.0 & 0.0 & 0.0 & 0.0 & 0.0 & 0.0 & 0.0 \\
\hline United Kingdom & UK1U & 710 & Morus bassanus & 2.2 & 3.8 & 0.1 & 1.6 & 0.5 & 3.5 & 11.8 \\
\hline United Kingdom & UK1U & 720 & Phalacrocorax carbo & 0.0 & 0.0 & 0.0 & 0.2 & 0.0 & 0.0 & 0.2 \\
\hline United Kingdom & UK1U & 2060 & Somoteria mollissima & 0.0 & 0.0 & 0.0 & 0.0 & 0.0 & 0.0 & 0.0 \\
\hline United Kingdom & UK1U & 6110 & Thalasseus sandvicensis & 0.0 & 0.0 & 0.0 & 0.0 & 0.0 & 0.0 & 0.0 \\
\hline United Kingdom & UK1U & 6340 & Uria aalge & 176.2 & 106.6 & 141.2 & 88.6 & 72.2 & 227.0 & 811.9 \\
\hline United Kingdom & UK23 & 6360 & Alca torda & 0.0 & 0.0 & 0.0 & 0.0 & 0.0 & 0.1 & 0.2 \\
\hline United Kingdom & UK23 & 6540 & Fratercula arctica & 0.0 & 0.0 & 0.0 & 0.0 & 0.0 & 0.0 & 0.1 \\
\hline United Kingdom & UK23 & 220 & Fulmarus glacialis & 0.0 & 0.0 & 0.0 & 0.0 & 0.0 & 0.0 & 0.0 \\
\hline United Kingdom & UK23 & 59 & Gavia sp & 0.0 & 0.0 & 4.2 & 0.0 & 0.0 & 0.0 & 4.3 \\
\hline United Kingdom & UK23 & 2130 & Melanitta nigra & 0.0 & 0.1 & 0.0 & 0.0 & 0.0 & 0.0 & 0.1 \\
\hline United Kingdom & UK23 & 710 & Morus bassanus & 0.0 & 0.0 & 0.0 & 0.0 & 0.0 & 0.0 & 0.0 \\
\hline United Kingdom & UK23 & 720 & Phalacrocorax carbo & 0.0 & 0.0 & 0.0 & 0.0 & 0.0 & 0.0 & 0.0 \\
\hline United Kingdom & UK23 & 2060 & Somoteria mollissima & 0.0 & 0.0 & 0.0 & 0.0 & 0.0 & 0.0 & 0.0 \\
\hline United Kingdom & UK23 & 6110 & Thalasseus sandvicensis & 0.0 & 0.0 & 0.0 & 0.0 & 0.4 & 0.0 & 0.4 \\
\hline United Kingdom & UK23 & 6340 & Uria aalge & 0.2 & 0.1 & 1.5 & 0.7 & 0.3 & 1.1 & 3.9 \\
\hline United Kingdom & UK27 & 6360 & Alca torda & 0.5 & 0.2 & 1.7 & 0.0 & 0.0 & 1.1 & 3.5 \\
\hline United Kingdom & UK27 & 6540 & Fratercula arctica & 0.0 & 0.1 & 0.3 & 0.0 & 0.0 & 0.1 & 0.4 \\
\hline United Kingdom & UK27 & 220 & Fulmarus glacialis & 0.0 & 0.0 & 0.0 & 0.0 & 0.1 & 0.0 & 0.1 \\
\hline United Kingdom & UK27 & 59 & Gavia sp & 0.0 & 0.7 & 0.0 & 0.4 & 0.6 & 0.0 & 1.8 \\
\hline United Kingdom & UK27 & 2130 & Melanitta nigra & 0.0 & 1.9 & 0.0 & 0.0 & 0.0 & 0.0 & 1.9 \\
\hline United Kingdom & UK27 & 710 & Morus bassanus & 0.0 & 0.0 & 0.0 & 0.0 & 0.0 & 0.0 & 0.1 \\
\hline United Kingdom & UK27 & 720 & Phalacrocorax carbo & 0.0 & 0.0 & 0.0 & 0.0 & 0.0 & 0.0 & 0.0 \\
\hline United Kingdom & UK27 & 2060 & Somoteria mollissima & 0.0 & 0.0 & 0.0 & 0.0 & 0.0 & 0.0 & 0.0 \\
\hline United Kingdom & UK27 & 6110 & Thalasseus sandvicensis & 0.0 & 0.0 & 0.0 & 0.0 & 0.5 & 0.0 & 0.5 \\
\hline United Kingdom & UK27 & 6340 & Uria aalge & 1.5 & 2.5 & 0.8 & 0.3 & 3.8 & 3.4 & 12.3 \\
\hline United Kingdom & UK28 & 6360 & Alca torda & 0.3 & 0.3 & 0.3 & 0.0 & 0.0 & 0.0 & 0.9 \\
\hline United Kingdom & UK28 & 6540 & Fratercula arctica & 0.0 & 0.0 & 0.2 & 0.2 & 0.1 & 0.0 & 0.5 \\
\hline United Kingdom & UK28 & 220 & Fulmarus glacialis & 0.0 & 0.0 & 0.0 & 0.0 & 0.0 & 0.0 & 0.1 \\
\hline United Kingdom & UK28 & 59 & Gavia sp & 0.0 & 0.0 & 0.0 & 0.0 & 0.0 & 0.0 & 0.0 \\
\hline United Kingdom & UK28 & 2130 & Melanitta nigra & 0.0 & 0.0 & 0.0 & 0.0 & 0.0 & 0.0 & 0.0 \\
\hline United Kingdom & UK28 & 710 & Morus bassanus & 0.0 & 0.0 & 0.0 & 0.0 & 0.0 & 0.0 & 0.1 \\
\hline
\end{tabular}




\begin{tabular}{|c|c|c|c|c|c|c|c|c|c|c|}
\hline $\begin{array}{l}\text { CountryName } \\
\end{array}$ & UniekID & EUring & species & $\mathrm{Aug}+\mathrm{Sep}$ & Okt + Nov & Dec + Jan & $\mathrm{Feb}+\mathrm{Mar}$ & Apr + May & Jun + Jul & Total \\
\hline United Kingdom & UK28 & 720 & Phalacrocorax carbo & 0.0 & 0.0 & 0.0 & 0.0 & 0.0 & 0.0 & 0.0 \\
\hline United Kingdom & UK28 & 2060 & Somoteria mollissima & 0.0 & 0.0 & 0.0 & 0.0 & 0.0 & 0.0 & 0.0 \\
\hline United Kingdom & UK28 & 6110 & Thalasseus sandvicensis & 0.0 & 0.0 & 0.0 & 0.0 & 0.0 & 0.0 & 0.0 \\
\hline United Kingdom & UK28 & 6340 & Uria aalge & 2.9 & 0.7 & 2.0 & 0.7 & 3.9 & 3.8 & 14.2 \\
\hline United Kingdom & UK29 & 6360 & Alca torda & 0.0 & 0.2 & 0.4 & 0.7 & 0.0 & 0.0 & 1.3 \\
\hline United Kingdom & UK29 & 6540 & Fratercula arctica & 0.0 & 0.0 & 0.0 & 0.0 & 0.0 & 0.0 & 0.0 \\
\hline United Kingdom & UK29 & 220 & Fulmarus glacialis & 0.0 & 0.1 & 0.0 & 0.0 & 0.1 & 0.1 & 0.2 \\
\hline United Kingdom & UK29 & 59 & Gavia sp & 0.0 & 0.1 & 0.2 & 1.4 & 0.4 & 0.0 & 2.2 \\
\hline United Kingdom & UK29 & 2130 & Melanitta nigra & 0.0 & 0.0 & 0.0 & 0.0 & 0.0 & 0.0 & 0.0 \\
\hline United Kingdom & UK29 & 710 & Morus bassanus & 0.0 & 0.3 & 0.2 & 0.1 & 0.0 & 0.1 & 0.8 \\
\hline United Kingdom & UK29 & 720 & Phalacrocorax carbo & 0.0 & 0.0 & 0.0 & 0.0 & 0.0 & 0.0 & 0.0 \\
\hline United Kingdom & UK29 & 2060 & Somoteria mollissima & 0.0 & 0.0 & 0.0 & 0.0 & 0.0 & 0.0 & 0.0 \\
\hline United Kingdom & UK29 & 6110 & Thalasseus sandvicensis & 0.0 & 0.0 & 0.0 & 0.0 & 0.0 & 0.1 & 0.1 \\
\hline United Kingdom & UK29 & 6340 & Uria aalge & 0.0 & 1.5 & 4.6 & 1.5 & 1.9 & 0.0 & 9.5 \\
\hline United Kingdom & UK2Q & 6360 & Alca torda & 0.0 & 0.2 & 0.3 & 2.2 & 1.0 & 0.0 & 3.7 \\
\hline United Kingdom & UK2Q & 6540 & Fratercula arctica & 0.0 & 0.0 & 0.0 & 0.0 & 0.0 & 0.0 & 0.0 \\
\hline United Kingdom & UK2Q & 220 & Fulmarus glacialis & 0.2 & 0.0 & 0.3 & 0.4 & 0.1 & 0.1 & 1.1 \\
\hline United Kingdom & UK2Q & 59 & Gavia sp & 0.0 & 0.0 & 1.6 & 0.2 & 0.3 & 0.0 & 2.1 \\
\hline United Kingdom & UK2Q & 2130 & Melanitta nigra & 0.0 & 0.0 & 0.0 & 0.0 & 0.0 & 0.0 & 0.0 \\
\hline United Kingdom & UK2Q & 710 & Morus bassanus & 0.0 & 0.1 & 0.1 & 0.0 & 0.0 & 0.0 & 0.3 \\
\hline United Kingdom & UK2Q & 720 & Phalacrocorax carbo & 0.0 & 0.0 & 0.0 & 0.0 & 0.0 & 0.0 & 0.0 \\
\hline United Kingdom & UK2Q & 2060 & Somoteria mollissima & 0.0 & 0.0 & 0.0 & 0.0 & 0.0 & 0.0 & 0.0 \\
\hline United Kingdom & UK2Q & 6110 & Thalasseus sandvicensis & 0.0 & 0.0 & 0.0 & 0.0 & 0.0 & 0.0 & 0.0 \\
\hline United Kingdom & UK2Q & 6340 & Uria aalge & 0.4 & 2.8 & 12.0 & 1.7 & 10.7 & 12.4 & 39.9 \\
\hline United Kingdom & UK30 & 6360 & Alca torda & 55.9 & 0.0 & 8.3 & 0.8 & 0.2 & 41.3 & 106.4 \\
\hline United Kingdom & UK30 & 6540 & Fratercula arctica & 1.2 & 0.3 & 0.1 & 0.0 & 0.7 & 0.7 & 3.0 \\
\hline United Kingdom & UK30 & 220 & Fulmarus glacialis & 0.1 & 0.0 & 0.0 & 0.0 & 0.2 & 0.3 & 0.6 \\
\hline United Kingdom & UK30 & 59 & Gavia sp & 0.0 & 0.2 & 0.0 & 1.3 & 0.0 & 0.0 & 1.6 \\
\hline United Kingdom & UK30 & 2130 & Melanitta nigra & 0.0 & 0.0 & 0.0 & 0.0 & 0.0 & 0.0 & 0.0 \\
\hline United Kingdom & UK30 & 710 & Morus bassanus & 0.3 & 0.0 & 0.0 & 0.0 & 0.0 & 1.9 & 2.2 \\
\hline United Kingdom & UK30 & 720 & Phalacrocorax carbo & 0.0 & 0.0 & 0.0 & 0.0 & 0.0 & 0.0 & 0.0 \\
\hline United Kingdom & UK30 & 2060 & Somoteria mollissima & 0.0 & 0.0 & 0.0 & 0.0 & 0.0 & 0.0 & 0.0 \\
\hline United Kingdom & UK30 & 6110 & Thalasseus sandvicensis & 0.0 & 0.0 & 0.0 & 0.0 & 2.2 & 0.0 & 2.2 \\
\hline United Kingdom & UK30 & 6340 & Uria aalge & 88.5 & 1.0 & 11.3 & 18.4 & 5.3 & 41.1 & 165.6 \\
\hline United Kingdom & UK34 & 6360 & Alca torda & 0.3 & 0.0 & 1.6 & 0.8 & 0.8 & 11.7 & 15.4 \\
\hline United Kingdom & UK34 & 6540 & Fratercula arctica & 0.5 & 0.0 & 1.6 & 0.4 & 1.1 & 2.3 & 5.9 \\
\hline United Kingdom & UK34 & 220 & Fulmarus glacialis & 0.0 & 0.1 & 0.0 & 0.0 & 0.0 & 0.0 & 0.2 \\
\hline United Kingdom & UK34 & 59 & Gavia sp & 0.0 & 0.0 & 0.0 & 0.0 & 0.0 & 0.0 & 0.0 \\
\hline United Kingdom & UK34 & 2130 & Melanitta nigra & 0.0 & 0.0 & 0.0 & 0.0 & 0.0 & 0.0 & 0.0 \\
\hline United Kingdom & UK34 & 710 & Morus bassanus & 0.2 & 0.0 & 0.0 & 0.1 & 0.0 & 0.2 & 0.4 \\
\hline United Kingdom & UK34 & 720 & Phalacrocorax carbo & 0.0 & 0.0 & 0.0 & 0.0 & 0.0 & 0.0 & 0.0 \\
\hline United Kingdom & UK34 & 2060 & Somoteria mollissima & 0.0 & 0.0 & 0.0 & 0.0 & 0.0 & 0.0 & 0.0 \\
\hline United Kingdom & UK34 & 6110 & Thalasseus sandvicensis & 0.0 & 0.0 & 0.0 & 0.0 & 0.1 & 0.0 & 0.1 \\
\hline United Kingdom & UK34 & 6340 & Uria aalge & 2.5 & 0.5 & 5.4 & 2.4 & 6.4 & 2.6 & 19.8 \\
\hline United Kingdom & UK39 & 6360 & Alca torda & 0.0 & 0.0 & 1.7 & 2.0 & 0.0 & 0.0 & 3.8 \\
\hline United Kingdom & UK39 & 6540 & Fratercula arctica & 0.0 & 0.0 & 0.0 & 0.0 & 0.0 & 0.0 & 0.0 \\
\hline United Kingdom & UK39 & 220 & Fulmarus glacialis & 0.2 & 0.0 & 0.3 & 0.4 & 0.1 & 0.1 & 1.2 \\
\hline United Kingdom & UK39 & 59 & Gavia sp & 0.0 & 0.0 & 0.3 & 0.2 & 0.0 & 0.0 & 0.5 \\
\hline United Kingdom & UK39 & 2130 & Melanitta nigra & 0.0 & 0.0 & 0.0 & 0.0 & 0.0 & 0.0 & 0.0 \\
\hline United Kingdom & UK39 & 710 & Morus bassanus & 0.2 & 0.0 & 0.0 & 0.0 & 0.0 & 0.1 & 0.4 \\
\hline United Kingdom & UK39 & 720 & Phalacrocorax carbo & 0.0 & 0.0 & 0.0 & 0.0 & 0.0 & 0.0 & 0.0 \\
\hline United Kingdom & UK39 & 2060 & Somoteria mollissima & 0.0 & 0.0 & 0.0 & 0.0 & 0.0 & 0.0 & 0.0 \\
\hline United Kingdom & UK39 & 6110 & Thalasseus sandvicensis & 0.1 & 0.0 & 0.0 & 0.0 & 0.0 & 0.0 & 0.1 \\
\hline United Kingdom & UK39 & 6340 & Uria aalge & 0.1 & 0.8 & 5.3 & 3.0 & 2.4 & 14.0 & 25.6 \\
\hline United Kingdom & UK3F & 6360 & Alca torda & 25.2 & 0.6 & 1.8 & 1.0 & 6.1 & 6.2 & 40.8 \\
\hline United Kingdom & UK3F & 6540 & Fratercula arctica & 21.6 & 0.3 & 0.0 & 0.3 & 0.9 & 0.7 & 23.7 \\
\hline
\end{tabular}




\begin{tabular}{|c|c|c|c|c|c|c|c|c|c|c|}
\hline $\begin{array}{l}\text { CountryName } \\
\end{array}$ & UniekID & EUring & species & $\mathrm{Aug}+\mathrm{Sep}$ & Okt + Nov & Dec + Jan & $\mathrm{Feb}+\mathrm{Mar}$ & Apr + May & Jun + Jul & Total \\
\hline United Kingdom & UK3F & 220 & Fulmarus glacialis & 0.3 & 0.3 & 0.3 & 0.1 & 0.1 & 0.3 & 1.5 \\
\hline United Kingdom & UK3F & 59 & Gavia sp & 0.0 & 0.0 & 0.0 & 0.0 & 0.0 & 0.0 & 0.0 \\
\hline United Kingdom & UK3F & 2130 & Melanitta nigra & 0.0 & 0.0 & 0.0 & 0.0 & 0.0 & 0.0 & 0.0 \\
\hline United Kingdom & UK3F & 710 & Morus bassanus & 0.3 & 0.1 & 0.6 & 0.3 & 1.3 & 0.5 & 3.2 \\
\hline United Kingdom & UK3F & 720 & Phalacrocorax carbo & 0.0 & 0.0 & 0.0 & 0.0 & 0.0 & 0.0 & 0.0 \\
\hline United Kingdom & UK3F & 2060 & Somoteria mollissima & 0.0 & 0.0 & 0.0 & 0.0 & 0.0 & 0.0 & 0.0 \\
\hline United Kingdom & UK3F & 6110 & Thalasseus sandvicensis & 0.0 & 0.0 & 0.0 & 0.0 & 0.0 & 0.0 & 0.0 \\
\hline United Kingdom & UK3F & 6340 & Uria aalge & 61.2 & 49.9 & 6.8 & 22.9 & 38.7 & 73.7 & 253.1 \\
\hline United Kingdom & UK40 & 6360 & Alca torda & 1.2 & 3.9 & 49.2 & 5.9 & 54.7 & 35.9 & 150.9 \\
\hline United Kingdom & UK40 & 6540 & Fratercula arctica & 6.4 & 0.2 & 0.8 & 0.8 & 1.9 & 10.2 & 20.3 \\
\hline United Kingdom & UK40 & 220 & Fulmarus glacialis & 0.7 & 0.4 & 0.2 & 0.9 & 0.3 & 1.4 & 3.9 \\
\hline United Kingdom & UK40 & 59 & Gavia sp & 0.0 & 2.0 & 0.0 & 0.0 & 0.0 & 0.0 & 2.0 \\
\hline United Kingdom & UK40 & 2130 & Melanitta nigra & 0.0 & 0.0 & 0.0 & 0.0 & 0.0 & 0.0 & 0.0 \\
\hline United Kingdom & UK40 & 710 & Morus bassanus & 0.9 & 0.9 & 0.3 & 2.2 & 0.3 & 1.3 & 5.9 \\
\hline United Kingdom & UK40 & 720 & Phalacrocorax carbo & 0.0 & 0.2 & 0.0 & 0.0 & 0.0 & 0.0 & 0.2 \\
\hline United Kingdom & UK40 & 2060 & Somoteria mollissima & 0.0 & 0.0 & 0.0 & 0.0 & 0.0 & 0.0 & 0.0 \\
\hline United Kingdom & UK40 & 6110 & Thalasseus sandvicensis & 0.0 & 0.0 & 0.0 & 0.0 & 0.0 & 0.0 & 0.0 \\
\hline United Kingdom & UK40 & 6340 & Uria aalge & 6.8 & 11.2 & 491.4 & 23.1 & 95.0 & 277.6 & 905.0 \\
\hline United Kingdom & UK44 & 6360 & Alca torda & 68.0 & 0.9 & 6.3 & 15.1 & 18.7 & 41.0 & 150.1 \\
\hline United Kingdom & UK44 & 6540 & Fratercula arctica & 50.3 & 0.7 & 1.7 & 0.2 & 8.2 & 21.5 & 82.7 \\
\hline United Kingdom & UK44 & 220 & Fulmarus glacialis & 1.4 & 0.7 & 2.0 & 0.1 & 0.6 & 0.8 & 5.7 \\
\hline United Kingdom & UK44 & 59 & Gavia sp & 0.0 & 0.0 & 0.0 & 0.0 & 0.0 & 0.1 & 0.1 \\
\hline United Kingdom & UK44 & 2130 & Melanitta nigra & 0.0 & 0.0 & 0.0 & 0.0 & 0.0 & 0.0 & 0.0 \\
\hline United Kingdom & UK44 & 710 & Morus bassanus & 2.0 & 0.5 & 0.3 & 1.7 & 2.8 & 3.0 & 10.3 \\
\hline United Kingdom & UK44 & 720 & Phalacrocorax carbo & 0.0 & 0.0 & 0.0 & 0.0 & 0.0 & 0.0 & 0.0 \\
\hline United Kingdom & UK44 & 2060 & Somoteria mollissima & 0.0 & 0.0 & 0.0 & 0.0 & 0.0 & 0.0 & 0.0 \\
\hline United Kingdom & UK44 & 6110 & Thalasseus sandvicensis & 0.0 & 0.0 & 0.0 & 0.0 & 0.4 & 0.0 & 0.4 \\
\hline United Kingdom & UK44 & 6340 & Uria aalge & 201.9 & 24.5 & 30.4 & 78.8 & 624.0 & 280.5 & 1240.2 \\
\hline United Kingdom & UK47 & 6360 & Alca torda & 1.7 & 0.0 & 0.4 & 0.2 & 6.3 & 0.8 & 9.5 \\
\hline United Kingdom & UK47 & 6540 & Fratercula arctica & 0.1 & 0.0 & 0.0 & 0.0 & 0.0 & 0.4 & 0.6 \\
\hline United Kingdom & UK47 & 220 & Fulmarus glacialis & 0.1 & 0.0 & 0.1 & 0.0 & 0.0 & 0.0 & 0.2 \\
\hline United Kingdom & UK47 & 59 & Gavia sp & 0.0 & 0.0 & 0.5 & 0.0 & 0.0 & 0.0 & 0.5 \\
\hline United Kingdom & UK47 & 2130 & Melanitta nigra & 0.0 & 0.0 & 0.0 & 0.0 & 0.0 & 0.0 & 0.0 \\
\hline United Kingdom & UK47 & 710 & Morus bassanus & 0.3 & 0.0 & 0.0 & 0.0 & 0.4 & 0.4 & 1.2 \\
\hline United Kingdom & UK47 & 720 & Phalacrocorax carbo & 0.0 & 0.0 & 0.0 & 0.0 & 0.0 & 0.0 & 0.1 \\
\hline United Kingdom & UK47 & 2060 & Somoteria mollissima & 6.3 & 0.0 & 0.0 & 0.0 & 0.0 & 0.0 & 6.3 \\
\hline United Kingdom & UK47 & 6110 & Thalasseus sandvicensis & 0.4 & 0.0 & 0.0 & 0.0 & 0.0 & 0.2 & 0.6 \\
\hline United Kingdom & UK47 & 6340 & Uria aalge & 21.3 & 31.4 & 6.2 & 2.7 & 14.9 & 6.3 & 82.8 \\
\hline United Kingdom & UK4F & 6360 & Alca torda & 0.2 & 0.0 & 1.4 & 0.0 & 0.0 & 4.5 & 6.2 \\
\hline United Kingdom & UK4F & 6540 & Fratercula arctica & 0.0 & 0.2 & 0.8 & 0.0 & 0.1 & 0.0 & 1.1 \\
\hline United Kingdom & UK4F & 220 & Fulmarus glacialis & 0.0 & 0.0 & 0.0 & 0.0 & 0.0 & 0.0 & 0.1 \\
\hline United Kingdom & UK4F & 59 & Gavia sp & 0.0 & 0.1 & 0.0 & 2.0 & 0.0 & 0.0 & 2.1 \\
\hline United Kingdom & UK4F & 2130 & Melanitta nigra & 0.0 & 0.2 & 0.0 & 0.0 & 0.0 & 0.0 & 0.2 \\
\hline United Kingdom & UK4F & 710 & Morus bassanus & 0.0 & 0.0 & 0.0 & 0.0 & 0.0 & 0.2 & 0.2 \\
\hline United Kingdom & UK4F & 720 & Phalacrocorax carbo & 0.0 & 0.0 & 0.0 & 0.0 & 0.0 & 0.0 & 0.0 \\
\hline United Kingdom & UK4F & 2060 & Somoteria mollissima & 0.0 & 0.0 & 0.0 & 0.0 & 0.0 & 0.0 & 0.0 \\
\hline United Kingdom & UK4F & 6110 & Thalasseus sandvicensis & 0.0 & 0.0 & 0.0 & 0.0 & 0.6 & 0.0 & 0.6 \\
\hline United Kingdom & UK4F & 6340 & 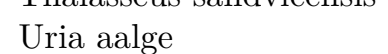 & 4.9 & 1.2 & 2.0 & 2.7 & 2.6 & 6.4 & 19.9 \\
\hline United Kingdom & UK4G & 6360 & Alca torda & 0.5 & 0.3 & 0.2 & 0.2 & 0.1 & 1.6 & 2.8 \\
\hline United Kingdom & UK4G & 6540 & Fratercula arctica & 0.5 & 0.1 & 0.4 & 0.0 & 0.0 & 0.0 & 1.0 \\
\hline United Kingdom & UK4G & 220 & Fulmarus glacialis & 0.0 & 0.0 & 0.0 & 0.0 & 0.0 & 0.0 & 0.1 \\
\hline United Kingdom & UK4G & 59 & Gavia sp & 0.0 & 0.2 & 0.0 & 0.1 & 0.3 & 0.0 & 0.6 \\
\hline United Kingdom & UK4G & 2130 & Melanitta nigra & 0.0 & 0.5 & 0.0 & 0.0 & 0.0 & 0.0 & 0.5 \\
\hline United Kingdom & UK4G & 710 & Morus bassanus & 0.1 & 0.0 & 0.0 & 0.0 & 0.0 & 0.0 & 0.1 \\
\hline United Kingdom & UK4G & 720 & Phalacrocorax carbo & 0.0 & 0.0 & 0.0 & 0.0 & 0.0 & 0.0 & 0.0 \\
\hline United Kingdom & UK4G & 2060 & Somoteria mollissima & 0.0 & 0.0 & 0.0 & 0.0 & 0.0 & 0.0 & 0.0 \\
\hline
\end{tabular}




\begin{tabular}{|c|c|c|c|c|c|c|c|c|c|c|}
\hline $\begin{array}{l}\text { CountryName } \\
\end{array}$ & UniekID & EUring & species & $\mathrm{Aug}+\mathrm{Sep}$ & Okt + Nov & Dec + Jan & $\mathrm{Feb}+\mathrm{Mar}$ & Apr + May & Jun + Jul & Total \\
\hline United Kingdom & UK4G & 6110 & Thalasseus sandvicensis & 0.0 & 0.0 & 0.0 & 0.0 & 0.4 & 0.0 & 0.4 \\
\hline United Kingdom & UK4G & 6340 & Uria aalge & 18.8 & 2.6 & 0.7 & 2.1 & 3.2 & 3.8 & 31.3 \\
\hline United Kingdom & UK4H & 6360 & Alca torda & 0.4 & 0.1 & 1.2 & 0.0 & 0.0 & 0.8 & 2.5 \\
\hline United Kingdom & UK4H & 6540 & Fratercula arctica & 0.0 & 0.1 & 0.2 & 0.0 & 0.0 & 0.0 & 0.2 \\
\hline United Kingdom & UK4H & 220 & Fulmarus glacialis & 0.0 & 0.0 & 0.0 & 0.0 & 0.0 & 0.0 & 0.1 \\
\hline United Kingdom & UK4H & 59 & Gavia sp & 0.0 & 0.4 & 0.0 & 0.3 & 0.3 & 0.0 & 1.0 \\
\hline United Kingdom & UK4H & 2130 & Melanitta nigra & 0.0 & 1.0 & 0.0 & 0.0 & 0.0 & 0.0 & 1.0 \\
\hline United Kingdom & UK4H & 710 & Morus bassanus & 0.0 & 0.0 & 0.0 & 0.0 & 0.0 & 0.0 & 0.1 \\
\hline United Kingdom & UK4H & 720 & Phalacrocorax carbo & 0.0 & 0.0 & 0.0 & 0.0 & 0.0 & 0.0 & 0.0 \\
\hline United Kingdom & UK4H & 2060 & Somoteria mollissima & 0.0 & 0.0 & 0.0 & 0.0 & 0.0 & 0.0 & 0.0 \\
\hline United Kingdom & UK4H & 6110 & Thalasseus sandvicensis & 0.0 & 0.0 & 0.0 & 0.0 & 0.3 & 0.0 & 0.3 \\
\hline United Kingdom & UK4H & 6340 & Uria aalge & 1.5 & 1.4 & 0.6 & 0.3 & 2.4 & 2.2 & 8.5 \\
\hline United Kingdom & UK4I & 6360 & Alca torda & 0.0 & 0.0 & 0.7 & 0.7 & 0.0 & 0.0 & 1.5 \\
\hline United Kingdom & UK4I & 6540 & Fratercula arctica & 0.0 & 0.0 & 0.0 & 0.1 & 0.0 & 0.0 & 0.1 \\
\hline United Kingdom & UK4I & 220 & Fulmarus glacialis & 0.1 & 0.0 & 0.0 & 0.1 & 0.1 & 0.0 & 0.3 \\
\hline United Kingdom & UK4I & 59 & Gavia sp & 0.0 & 0.0 & 0.0 & 0.1 & 0.0 & 0.0 & 0.1 \\
\hline United Kingdom & UK4I & 2130 & Melanitta nigra & 0.0 & 0.0 & 0.0 & 0.0 & 0.0 & 0.0 & 0.0 \\
\hline United Kingdom & UK4I & 710 & Morus bassanus & 0.1 & 0.1 & 0.0 & 0.1 & 0.0 & 0.0 & 0.3 \\
\hline United Kingdom & UK4I & 720 & Phalacrocorax carbo & 0.0 & 0.0 & 0.0 & 0.0 & 0.0 & 0.0 & 0.0 \\
\hline United Kingdom & UK4I & 2060 & Somoteria mollissima & 0.0 & 0.0 & 0.0 & 0.0 & 0.0 & 0.0 & 0.0 \\
\hline United Kingdom & UK4I & 6110 & Thalasseus sandvicensis & 0.0 & 0.0 & 0.0 & 0.0 & 0.0 & 0.0 & 0.0 \\
\hline United Kingdom & UK4I & 6340 & Uria aalge & 0.0 & 0.1 & 1.3 & 3.3 & 0.4 & 0.4 & 5.5 \\
\hline United Kingdom & UK4J & 6360 & Alca torda & 0.0 & 0.1 & 0.6 & 1.0 & 0.1 & 0.0 & 1.7 \\
\hline United Kingdom & UK4J & 6540 & Fratercula arctica & 0.0 & 0.0 & 0.0 & 0.4 & 0.0 & 0.0 & 0.4 \\
\hline United Kingdom & UK4J & 220 & Fulmarus glacialis & 0.1 & 0.0 & 0.0 & 0.0 & 0.0 & 0.1 & 0.3 \\
\hline United Kingdom & UK4J & 59 & Gavia sp & 0.0 & 0.0 & 0.0 & 0.2 & 0.0 & 0.0 & 0.2 \\
\hline United Kingdom & UK4J & 2130 & Melanitta nigra & 0.0 & 0.0 & 0.0 & 0.0 & 0.0 & 0.0 & 0.0 \\
\hline United Kingdom & UK4J & 710 & Morus bassanus & 0.1 & 0.1 & 0.0 & 0.1 & 0.0 & 0.1 & 0.4 \\
\hline United Kingdom & UK4J & 720 & Phalacrocorax carbo & 0.0 & 0.0 & 0.0 & 0.0 & 0.0 & 0.0 & 0.0 \\
\hline United Kingdom & UK4J & 2060 & Somoteria mollissima & 0.0 & 0.0 & 0.0 & 0.0 & 0.0 & 0.0 & 0.0 \\
\hline United Kingdom & UK4J & 6110 & Thalasseus sandvicensis & 0.0 & 0.0 & 0.0 & 0.0 & 0.0 & 0.0 & 0.0 \\
\hline United Kingdom & UK4J & 6340 & Uria aalge & 0.0 & 0.3 & 1.9 & 3.8 & 0.3 & 0.4 & 6.9 \\
\hline United Kingdom & UK4N & 6360 & Alca torda & 14.5 & 0.3 & 1.0 & 0.4 & 4.9 & 4.7 & 25.8 \\
\hline United Kingdom & UK4N & 6540 & Fratercula arctica & 1.2 & 0.0 & 0.0 & 0.1 & 0.0 & 0.3 & 1.7 \\
\hline United Kingdom & UK4N & 220 & Fulmarus glacialis & 0.1 & 0.1 & 0.1 & 0.1 & 0.0 & 0.1 & 0.4 \\
\hline United Kingdom & UK4N & 59 & Gavia sp & 0.0 & 0.0 & 0.0 & 0.0 & 0.0 & 0.0 & 0.0 \\
\hline United Kingdom & UK4N & 2130 & Melanitta nigra & 0.0 & 0.0 & 0.0 & 0.0 & 0.0 & 0.1 & 0.1 \\
\hline United Kingdom & UK4N & 710 & Morus bassanus & 0.2 & 0.0 & 0.1 & 0.2 & 0.4 & 0.3 & 1.3 \\
\hline United Kingdom & UK4N & 720 & Phalacrocorax carbo & 0.0 & 0.0 & 0.0 & 0.0 & 0.0 & 0.0 & 0.0 \\
\hline United Kingdom & UK4N & 2060 & Somoteria mollissima & 0.0 & 0.0 & 0.0 & 0.0 & 0.0 & 0.0 & 0.0 \\
\hline United Kingdom & UK4N & 6110 & Thalasseus sandvicensis & 0.0 & 0.0 & 0.0 & 0.0 & 0.0 & 0.0 & 0.0 \\
\hline United Kingdom & UK4N & 6340 & Uria aalge & 14.3 & 27.9 & 3.8 & 8.2 & 12.0 & 23.7 & 89.9 \\
\hline United Kingdom & UK4P & 6360 & Alca torda & 5.1 & 0.1 & 0.4 & 1.3 & 2.2 & 3.0 & 12.1 \\
\hline United Kingdom & UK4P & 6540 & Fratercula arctica & 4.6 & 0.1 & 0.1 & 0.0 & 1.0 & 2.1 & 8.0 \\
\hline United Kingdom & UK4P & 220 & Fulmarus glacialis & 0.1 & 0.1 & 0.1 & 0.0 & 0.1 & 0.0 & 0.3 \\
\hline United Kingdom & UK4P & 59 & Gavia sp & 0.0 & 0.0 & 0.0 & 0.0 & 0.0 & 0.0 & 0.0 \\
\hline United Kingdom & UK4P & 2130 & Melanitta nigra & 0.0 & 0.0 & 0.0 & 0.0 & 0.0 & 0.0 & 0.0 \\
\hline United Kingdom & UK4P & 710 & Morus bassanus & 0.2 & 0.1 & 0.0 & 0.2 & 0.2 & 0.3 & 1.0 \\
\hline United Kingdom & UK4P & 720 & Phalacrocorax carbo & 0.0 & 0.0 & 0.0 & 0.0 & 0.0 & 0.0 & 0.0 \\
\hline United Kingdom & UK4P & 2060 & Somoteria mollissima & 0.0 & 0.0 & 0.0 & 0.0 & 0.0 & 0.0 & 0.0 \\
\hline United Kingdom & UK4P & 6110 & Thalasseus sandvicensis & 0.0 & 0.0 & 0.0 & 0.0 & 0.0 & 0.0 & 0.0 \\
\hline United Kingdom & UK4P & 6340 & Uria aalge & 11.2 & 1.8 & 2.1 & 5.0 & 43.5 & 16.6 & 80.2 \\
\hline United Kingdom & UK53 & 6360 & Alca torda & 1.9 & 1.0 & 39.2 & 1.7 & 30.9 & 11.4 & 86.1 \\
\hline United Kingdom & UK53 & 6540 & Fratercula arctica & 6.9 & 0.1 & 0.4 & 0.2 & 0.9 & 1.4 & 10.0 \\
\hline United Kingdom & UK53 & 220 & Fulmarus glacialis & 0.4 & 0.2 & 0.1 & 0.6 & 0.2 & 0.8 & 2.2 \\
\hline United Kingdom & UK53 & 59 & Gavia sp & 0.0 & 0.6 & 0.0 & 0.0 & 0.0 & 0.0 & 0.6 \\
\hline
\end{tabular}




\begin{tabular}{|c|c|c|c|c|c|c|c|c|c|c|}
\hline CountryName & UniekID & EUring & species & Aug + Sep & Okt + Nov & Dec + Jan & Feb + Mar & Apr + May & Jun + Jul & Total \\
\hline United Kingdom & UK53 & 2130 & Melanitta nigra & 0.0 & 0.0 & 0.0 & 0.0 & 0.0 & 0.0 & 0.0 \\
\hline United Kingdom & UK53 & 710 & Morus bassanus & 0.3 & 0.4 & 0.2 & 0.1 & 0.2 & 0.1 & 1.3 \\
\hline United Kingdom & UK53 & 720 & Phalacrocorax carbo & 0.0 & 0.0 & 0.0 & 0.0 & 0.0 & 0.0 & 0.0 \\
\hline United Kingdom & UK53 & 2060 & Somoteria mollissima & 0.0 & 0.0 & 0.0 & 0.0 & 0.0 & 0.0 & 0.0 \\
\hline United Kingdom & UK53 & 6110 & Thalasseus sandvicensis & 0.0 & 0.0 & 0.0 & 0.0 & 0.0 & 0.0 & 0.0 \\
\hline United Kingdom & UK53 & 6340 & Uria aalge & 4.0 & 2.7 & 459.1 & 5.1 & 34.0 & 123.5 & 628.3 \\
\hline United Kingdom & UK54 & 6360 & Alca torda & 16.3 & 0.5 & 3.4 & 1.8 & 2.0 & 13.3 & 37.2 \\
\hline United Kingdom & UK54 & 6540 & Fratercula arctica & 12.0 & 0.2 & 0.1 & 0.0 & 1.7 & 29.3 & 43.3 \\
\hline United Kingdom & UK54 & 220 & Fulmarus glacialis & 0.2 & 0.2 & 0.2 & 0.1 & 0.3 & 0.1 & 1.0 \\
\hline United Kingdom & UK54 & 59 & Gavia sp & 0.0 & 0.0 & 0.0 & 0.0 & 0.0 & 0.0 & 0.0 \\
\hline United Kingdom & UK54 & 2130 & Melanitta nigra & 0.0 & 0.0 & 0.0 & 0.0 & 0.0 & 0.0 & 0.0 \\
\hline United Kingdom & UK54 & 710 & Morus bassanus & 0.9 & 0.3 & 0.1 & 1.3 & 0.3 & 0.7 & 3.5 \\
\hline United Kingdom & UK54 & 720 & Phalacrocorax carbo & 0.0 & 0.0 & 0.0 & 0.0 & 0.0 & 0.0 & 0.0 \\
\hline United Kingdom & UK54 & 2060 & Somoteria mollissima & 0.0 & 0.8 & 0.0 & 0.0 & 0.0 & 0.0 & 0.8 \\
\hline United Kingdom & UK54 & 6110 & Thalasseus sandvicensis & 0.0 & 0.0 & 0.0 & 0.0 & 0.0 & 0.0 & 0.0 \\
\hline United Kingdom & UK54 & 6340 & Uria aalge & 47.3 & 4.0 & 19.8 & 11.9 & 23.9 & 89.4 & 196.2 \\
\hline United Kingdom & UK56 & 6360 & Alca torda & 7.2 & 1.8 & 5.9 & 1.9 & 3.9 & 9.1 & 29.8 \\
\hline United Kingdom & UK56 & 6540 & Fratercula arctica & 9.2 & 0.1 & 1.8 & 1.0 & 32.4 & 126.3 & 170.8 \\
\hline United Kingdom & UK56 & 220 & Fulmarus glacialis & 0.2 & 0.1 & 0.4 & 0.2 & 0.2 & 0.0 & 1.2 \\
\hline United Kingdom & UK56 & 59 & Gavia sp & 0.0 & 0.0 & 0.0 & 0.0 & 0.0 & 0.0 & 0.0 \\
\hline United Kingdom & UK56 & 2130 & Melanitta nigra & 0.0 & 0.0 & 0.0 & 0.0 & 0.0 & 0.0 & 0.0 \\
\hline United Kingdom & UK56 & 710 & Morus bassanus & 1.0 & 0.4 & 0.6 & 0.8 & 1.5 & 1.3 & 5.5 \\
\hline United Kingdom & UK56 & 720 & Phalacrocorax carbo & 0.0 & 0.0 & 0.0 & 0.0 & 0.0 & 0.0 & 0.0 \\
\hline United Kingdom & UK56 & 2060 & Somoteria mollissima & 0.0 & 1.5 & 0.0 & 0.0 & 0.0 & 0.0 & 1.5 \\
\hline United Kingdom & UK56 & 6110 & Thalasseus sandvicensis & 0.0 & 0.0 & 0.0 & 0.0 & 0.0 & 0.0 & 0.0 \\
\hline United Kingdom & UK56 & 6340 & Uria aalge & 15.7 & 5.2 & 36.3 & 7.1 & 184.1 & 46.3 & 294.7 \\
\hline United Kingdom & UK60 & 6360 & Alca torda & 0.0 & 0.0 & 0.0 & 0.0 & 0.0 & 0.0 & 0.0 \\
\hline United Kingdom & UK60 & 6540 & Fratercula arctica & 0.0 & 0.0 & 0.0 & 0.0 & 0.0 & 0.0 & 0.0 \\
\hline United Kingdom & UK60 & 220 & Fulmarus glacialis & 0.0 & 0.0 & 0.0 & 0.0 & 0.0 & 0.0 & 0.0 \\
\hline United Kingdom & UK60 & 59 & Gavia sp & 0.0 & 0.3 & 0.9 & 0.4 & 0.1 & 0.0 & 1.6 \\
\hline United Kingdom & UK60 & 2130 & Melanitta nigra & 0.0 & 0.0 & 0.0 & 0.0 & 0.0 & 0.0 & 0.0 \\
\hline United Kingdom & UK60 & 710 & Morus bassanus & 0.0 & 0.0 & 0.0 & 0.0 & 0.0 & 0.0 & 0.1 \\
\hline United Kingdom & UK60 & 720 & Phalacrocorax carbo & 0.0 & 0.0 & 0.0 & 0.0 & 0.0 & 0.0 & 0.0 \\
\hline United Kingdom & UK60 & 2060 & Somoteria mollissima & 0.0 & 0.0 & 0.0 & 0.0 & 0.0 & 0.0 & 0.0 \\
\hline United Kingdom & UK60 & 6110 & Thalasseus sandvicensis & 0.2 & 0.0 & 0.0 & 0.0 & 0.0 & 0.1 & 0.3 \\
\hline United Kingdom & UK60 & 6340 & Uria aalge & 0.0 & 0.0 & 0.5 & 0.0 & 0.0 & 0.0 & 0.5 \\
\hline United Kingdom & UK62 & 6360 & Alca torda & 0.0 & 0.1 & 2.6 & 2.5 & 0.0 & 0.0 & 5.2 \\
\hline United Kingdom & UK62 & 6540 & Fratercula arctica & 0.0 & 0.0 & 0.0 & 1.0 & 0.0 & 0.0 & 1.0 \\
\hline United Kingdom & UK62 & 220 & Fulmarus glacialis & 0.2 & 0.1 & 0.0 & 0.2 & 0.1 & 0.3 & 0.8 \\
\hline United Kingdom & UK62 & 59 & Gavia sp & 0.0 & 0.0 & 0.0 & 0.7 & 0.0 & 0.0 & 0.7 \\
\hline United Kingdom & UK62 & 2130 & Melanitta nigra & 0.0 & 0.0 & 0.0 & 0.0 & 0.0 & 0.0 & 0.0 \\
\hline United Kingdom & UK62 & 710 & Morus bassanus & 0.2 & 0.5 & 0.0 & 0.3 & 0.0 & 0.2 & 1.1 \\
\hline United Kingdom & UK62 & 720 & Phalacrocorax carbo & 0.0 & 0.0 & 0.0 & 0.0 & 0.0 & 0.0 & 0.0 \\
\hline United Kingdom & UK62 & 2060 & Somoteria mollissima & 0.0 & 0.0 & 0.0 & 0.0 & 0.0 & 0.0 & 0.0 \\
\hline United Kingdom & UK62 & 6110 & Thalasseus sandvicensis & 0.0 & 0.0 & 0.0 & 0.0 & 0.0 & 0.0 & 0.0 \\
\hline United Kingdom & UK62 & 6340 & Uria aalge & 0.0 & 0.7 & 4.5 & 11.0 & 0.8 & 1.3 & 18.4 \\
\hline United Kingdom & UK64 & 6360 & Alca torda & 0.0 & 0.2 & 1.3 & 10.5 & 0.2 & 0.0 & 12.3 \\
\hline United Kingdom & UK64 & 6540 & Fratercula arctica & 0.0 & 0.0 & 0.0 & 0.0 & 0.0 & 0.0 & 0.0 \\
\hline United Kingdom & UK64 & 220 & Fulmarus glacialis & 0.6 & 0.0 & 0.4 & 1.4 & 0.3 & 0.3 & 3.0 \\
\hline United Kingdom & UK64 & 59 & Gavia sp & 0.0 & 0.0 & 0.0 & 0.6 & 0.1 & 0.0 & 0.8 \\
\hline United Kingdom & UK64 & 2130 & Melanitta nigra & 0.0 & 0.0 & 0.0 & 0.0 & 0.0 & 0.0 & 0.0 \\
\hline United Kingdom & UK64 & 710 & Morus bassanus & 0.3 & 0.5 & 0.4 & 0.3 & 0.1 & 0.2 & 1.8 \\
\hline United Kingdom & UK64 & 720 & Phalacrocorax carbo & 0.0 & 0.0 & 0.0 & 0.0 & 0.0 & 0.0 & 0.0 \\
\hline United Kingdom & UK64 & 2060 & Somoteria mollissima & 0.0 & 0.0 & 0.0 & 0.0 & 0.0 & 0.0 & 0.0 \\
\hline United Kingdom & UK64 & 6110 & Thalasseus sandvicensis & 0.0 & 0.0 & 0.0 & 0.0 & 0.1 & 0.0 & 0.1 \\
\hline United Kingdom & UK64 & 6340 & Uria aalge & 0.7 & 6.4 & 12.1 & 7.4 & 16.1 & 22.1 & 64.8 \\
\hline
\end{tabular}




\begin{tabular}{|c|c|c|c|c|c|c|c|c|c|c|}
\hline $\begin{array}{l}\text { CountryName } \\
\end{array}$ & UniekID & EUring & species & $\mathrm{Aug}+\mathrm{Sep}$ & Okt + Nov & Dec + Jan & $\mathrm{Feb}+\mathrm{Mar}$ & Apr + May & Jun + Jul & Total \\
\hline United Kingdom & UK66 & 6360 & Alca torda & 0.0 & 3.4 & 2.1 & 11.0 & 0.2 & 0.0 & 16.7 \\
\hline United Kingdom & UK66 & 6540 & Fratercula arctica & 0.0 & 0.0 & 0.1 & 0.0 & 0.0 & 0.0 & 0.1 \\
\hline United Kingdom & UK66 & 220 & Fulmarus glacialis & 0.8 & 0.3 & 0.4 & 0.6 & 0.3 & 0.5 & 2.9 \\
\hline United Kingdom & UK66 & 59 & Gavia sp & 0.0 & 0.0 & 0.0 & 0.0 & 0.0 & 0.0 & 0.0 \\
\hline United Kingdom & UK66 & 2130 & Melanitta nigra & 0.0 & 0.0 & 0.0 & 0.0 & 0.0 & 0.0 & 0.0 \\
\hline United Kingdom & UK66 & 710 & Morus bassanus & 0.1 & 1.4 & 0.6 & 0.4 & 0.2 & 0.0 & 2.7 \\
\hline United Kingdom & UK66 & 720 & Phalacrocorax carbo & 0.0 & 0.0 & 0.0 & 0.0 & 0.0 & 0.0 & 0.0 \\
\hline United Kingdom & UK66 & 2060 & Somoteria mollissima & 0.0 & 0.0 & 0.0 & 0.0 & 0.0 & 0.0 & 0.0 \\
\hline United Kingdom & UK66 & 6110 & Thalasseus sandvicensis & 0.0 & 0.0 & 0.0 & 0.0 & 0.0 & 0.0 & 0.0 \\
\hline United Kingdom & UK66 & 6340 & Uria aalge & 2.9 & 3.7 & 33.6 & 6.3 & 8.3 & 3.4 & 58.1 \\
\hline United Kingdom & UK67 & 6360 & Alca torda & 8.4 & 3.4 & 5.9 & 4.8 & 0.5 & 0.1 & 23.1 \\
\hline United Kingdom & UK67 & 6540 & Fratercula arctica & 0.0 & 0.0 & 0.0 & 0.0 & 0.1 & 0.0 & 0.1 \\
\hline United Kingdom & UK67 & 220 & Fulmarus glacialis & 1.1 & 0.3 & 0.4 & 0.5 & 0.6 & 0.7 & 3.6 \\
\hline United Kingdom & UK67 & 59 & Gavia sp & 0.0 & 0.0 & 0.1 & 0.0 & 0.6 & 0.0 & 0.7 \\
\hline United Kingdom & UK67 & 2130 & Melanitta nigra & 0.0 & 0.1 & 0.0 & 0.0 & 0.0 & 0.0 & 0.1 \\
\hline United Kingdom & UK67 & 710 & Morus bassanus & 0.3 & 2.3 & 0.1 & 0.1 & 0.3 & 0.0 & 3.2 \\
\hline United Kingdom & UK67 & 720 & Phalacrocorax carbo & 0.0 & 0.0 & 0.0 & 0.0 & 0.0 & 0.0 & 0.0 \\
\hline United Kingdom & UK67 & 2060 & Somoteria mollissima & 0.0 & 0.0 & 0.0 & 0.0 & 0.0 & 0.0 & 0.0 \\
\hline United Kingdom & UK67 & 6110 & Thalasseus sandvicensis & 0.0 & 0.0 & 0.0 & 0.0 & 0.0 & 0.0 & 0.0 \\
\hline United Kingdom & UK67 & 6340 & Uria aalge & 24.6 & 6.5 & 39.4 & 5.7 & 21.8 & 2.4 & 100.4 \\
\hline United Kingdom & UK69 & 6360 & Alca torda & 0.2 & 5.9 & 2.5 & 4.8 & 0.2 & 0.0 & 13.5 \\
\hline United Kingdom & UK69 & 6540 & Fratercula arctica & 0.0 & 0.0 & 0.0 & 0.0 & 0.0 & 0.0 & 0.0 \\
\hline United Kingdom & UK69 & 220 & Fulmarus glacialis & 0.9 & 0.2 & 0.4 & 0.4 & 0.7 & 0.5 & 3.0 \\
\hline United Kingdom & UK69 & 59 & Gavia sp & 0.0 & 0.2 & 0.0 & 1.1 & 0.3 & 0.0 & 1.6 \\
\hline United Kingdom & UK69 & 2130 & Melanitta nigra & 0.0 & 0.7 & 0.0 & 0.0 & 0.0 & 0.0 & 0.7 \\
\hline United Kingdom & UK69 & 710 & Morus bassanus & 0.2 & 2.1 & 0.3 & 0.0 & 0.2 & 0.0 & 2.9 \\
\hline United Kingdom & UK69 & 720 & Phalacrocorax carbo & 0.0 & 0.0 & 0.0 & 0.0 & 0.0 & 0.0 & 0.0 \\
\hline United Kingdom & UK69 & 2060 & Somoteria mollissima & 0.0 & 0.0 & 0.0 & 0.0 & 0.0 & 0.0 & 0.0 \\
\hline United Kingdom & UK69 & 6110 & Thalasseus sandvicensis & 0.0 & 0.0 & 0.0 & 0.0 & 0.0 & 0.0 & 0.0 \\
\hline United Kingdom & UK69 & 6340 & Uria aalge & 4.1 & 28.8 & 15.0 & 4.8 & 22.0 & 0.6 & 75.3 \\
\hline United Kingdom & UK70 & 6360 & Alca torda & 0.1 & 0.0 & 0.2 & 0.3 & 0.0 & 0.1 & 0.7 \\
\hline United Kingdom & UK70 & 6540 & Fratercula arctica & 0.0 & 0.0 & 0.0 & 0.5 & 0.1 & 0.5 & 1.2 \\
\hline United Kingdom & UK70 & 220 & Fulmarus glacialis & 0.0 & 0.2 & 0.0 & 0.0 & 0.0 & 0.0 & 0.2 \\
\hline United Kingdom & UK70 & 59 & Gavia sp & 0.0 & 0.0 & 0.0 & 0.0 & 0.0 & 0.0 & 0.0 \\
\hline United Kingdom & UK70 & 2130 & Melanitta nigra & 0.0 & 0.0 & 0.0 & 0.0 & 0.0 & 0.0 & 0.0 \\
\hline United Kingdom & UK70 & 710 & Morus bassanus & 0.0 & 0.0 & 0.0 & 0.0 & 0.0 & 0.1 & 0.2 \\
\hline United Kingdom & UK70 & 720 & Phalacrocorax carbo & 0.0 & 0.0 & 0.0 & 0.0 & 0.0 & 0.0 & 0.0 \\
\hline United Kingdom & UK70 & 2060 & Somoteria mollissima & 0.0 & 0.0 & 0.0 & 0.0 & 0.0 & 0.0 & 0.0 \\
\hline United Kingdom & UK70 & 6110 & Thalasseus sandvicensis & 0.0 & 0.0 & 0.0 & 0.0 & 0.0 & 0.0 & 0.0 \\
\hline United Kingdom & UK70 & 6340 & Uria aalge & 0.7 & 0.4 & 3.6 & 1.7 & 4.2 & 1.3 & 11.9 \\
\hline United Kingdom & UK74 & 6360 & Alca torda & 99.6 & 10.1 & 3.0 & 15.1 & 42.5 & 179.2 & 349.4 \\
\hline United Kingdom & UK74 & 6540 & Fratercula arctica & 119.2 & 10.6 & 43.3 & 1.3 & 11.6 & 46.9 & 232.8 \\
\hline United Kingdom & UK74 & 220 & Fulmarus glacialis & 2.0 & 1.1 & 0.9 & 1.0 & 0.3 & 2.2 & 7.5 \\
\hline United Kingdom & UK74 & 59 & Gavia sp & 0.0 & 0.0 & 0.0 & 0.0 & 0.0 & 0.0 & 0.0 \\
\hline United Kingdom & UK74 & 2130 & Melanitta nigra & 0.0 & 0.0 & 0.0 & 0.0 & 0.0 & 0.0 & 0.0 \\
\hline United Kingdom & UK74 & 710 & Morus bassanus & 2.7 & 3.2 & 5.2 & 2.3 & 6.8 & 5.7 & 25.8 \\
\hline United Kingdom & UK74 & 720 & Phalacrocorax carbo & 0.0 & 0.0 & 0.0 & 0.0 & 0.0 & 0.0 & 0.0 \\
\hline United Kingdom & UK74 & 2060 & Somoteria mollissima & 0.0 & 0.0 & 0.0 & 0.0 & 0.0 & 0.0 & 0.0 \\
\hline United Kingdom & UK74 & 6110 & Thalasseus sandvicensis & 0.0 & 0.0 & 0.0 & 0.0 & 9.4 & 0.0 & 9.4 \\
\hline United Kingdom & UK74 & 6340 & Uria aalge & 699.3 & 52.4 & 290.2 & 56.7 & 855.1 & 900.9 & 2854.6 \\
\hline United Kingdom & UK76 & 6360 & Alca torda & 0.3 & 2.0 & 0.5 & 0.0 & 0.2 & 2.2 & 5.2 \\
\hline United Kingdom & UK76 & 6540 & Fratercula arctica & 0.4 & 0.2 & 0.0 & 0.0 & 0.0 & 0.4 & 1.0 \\
\hline United Kingdom & UK76 & 220 & Fulmarus glacialis & 0.1 & 0.0 & 0.1 & 0.0 & 0.0 & 0.1 & 0.4 \\
\hline United Kingdom & UK76 & 59 & Gavia sp & 0.0 & 0.0 & 0.0 & 0.0 & 0.0 & 0.0 & 0.0 \\
\hline United Kingdom & UK76 & 2130 & Melanitta nigra & 0.0 & 0.0 & 0.0 & 0.0 & 0.0 & 0.0 & 0.0 \\
\hline United Kingdom & UK76 & 710 & Morus bassanus & 0.1 & 0.1 & 0.0 & 0.1 & 0.0 & 0.0 & 0.3 \\
\hline
\end{tabular}




\begin{tabular}{|c|c|c|c|c|c|c|c|c|c|c|}
\hline CountryName & UniekID & EUring & species & Aug + Sep & Okt + Nov & Dec + Jan & Feb + Mar & Apr + May & Jun + Jul & Total \\
\hline United Kingdom & UK76 & 720 & Phalacrocorax carbo & 0.0 & 0.0 & 0.0 & 0.0 & 0.0 & 0.0 & 0.0 \\
\hline United Kingdom & UK76 & 2060 & Somoteria mollissima & 0.0 & 0.0 & 0.0 & 0.0 & 0.0 & 0.0 & 0.0 \\
\hline United Kingdom & UK76 & 6110 & Thalasseus sandvicensis & 0.0 & 0.0 & 0.0 & 0.0 & 0.0 & 0.0 & 0.0 \\
\hline United Kingdom & UK76 & 6340 & Uria aalge & 14.4 & 8.3 & 0.8 & 1.4 & 1.1 & 23.6 & 49.5 \\
\hline United Kingdom & UK77 & 6360 & Alca torda & 0.6 & 3.5 & 14.6 & 3.1 & 11.7 & 5.0 & 38.5 \\
\hline United Kingdom & UK77 & 6540 & Fratercula arctica & 0.5 & 0.0 & 0.0 & 0.1 & 0.5 & 0.9 & 2.1 \\
\hline United Kingdom & UK77 & 220 & Fulmarus glacialis & 0.2 & 0.0 & 0.0 & 0.3 & 0.1 & 0.4 & 1.1 \\
\hline United Kingdom & UK77 & 59 & Gavia sp & 0.0 & 1.4 & 0.0 & 0.0 & 0.0 & 0.0 & 1.4 \\
\hline United Kingdom & UK77 & 2130 & Melanitta nigra & 0.0 & 0.0 & 0.0 & 0.0 & 0.0 & 0.0 & 0.0 \\
\hline United Kingdom & UK77 & 710 & Morus bassanus & 0.3 & 0.4 & 0.1 & 1.4 & 0.1 & 0.1 & 2.5 \\
\hline United Kingdom & UK77 & 720 & Phalacrocorax carbo & 0.0 & 0.1 & 0.0 & 0.0 & 0.0 & 0.0 & 0.1 \\
\hline United Kingdom & UK77 & 2060 & Somoteria mollissima & 0.0 & 0.0 & 0.0 & 0.0 & 0.0 & 0.0 & 0.0 \\
\hline United Kingdom & UK77 & 6110 & Thalasseus sandvicensis & 0.0 & 0.0 & 0.0 & 0.0 & 0.0 & 0.0 & 0.0 \\
\hline United Kingdom & UK77 & 6340 & Uria aalge & 0.5 & 9.3 & 111.7 & 4.7 & 25.1 & 49.9 & 201.0 \\
\hline United Kingdom & UK79 & 6360 & Alca torda & 1.0 & 0.3 & 0.7 & 0.9 & 0.0 & 0.2 & 3.0 \\
\hline United Kingdom & UK79 & 6540 & Fratercula arctica & 0.7 & 0.0 & 0.2 & 1.3 & 0.2 & 2.0 & 4.4 \\
\hline United Kingdom & UK79 & 220 & Fulmarus glacialis & 0.0 & 0.5 & 0.0 & 0.1 & 0.0 & 0.0 & 0.7 \\
\hline United Kingdom & UK79 & 59 & Gavia sp & 0.0 & 0.0 & 0.0 & 0.0 & 0.0 & 0.0 & 0.0 \\
\hline United Kingdom & UK79 & 2130 & Melanitta nigra & 0.0 & 0.0 & 0.0 & 0.0 & 0.0 & 0.0 & 0.0 \\
\hline United Kingdom & UK79 & 710 & Morus bassanus & 0.2 & 0.0 & 0.0 & 0.1 & 0.0 & 0.3 & 0.6 \\
\hline United Kingdom & UK79 & 720 & Phalacrocorax carbo & 0.0 & 0.0 & 0.0 & 0.0 & 0.0 & 0.0 & 0.0 \\
\hline United Kingdom & UK79 & 2060 & Somoteria mollissima & 0.0 & 0.0 & 0.0 & 0.0 & 0.0 & 0.0 & 0.0 \\
\hline United Kingdom & UK79 & 6110 & Thalasseus sandvicensis & 0.0 & 0.0 & 0.0 & 0.0 & 0.0 & 0.0 & 0.0 \\
\hline United Kingdom & UK79 & 6340 & Uria aalge & 5.7 & 1.2 & 13.6 & 4.9 & 13.9 & 4.4 & 43.7 \\
\hline United Kingdom & UK80 & 6360 & Alca torda & 4.1 & 42.6 & 2.6 & 77.1 & 24.1 & 23.5 & 174.0 \\
\hline United Kingdom & UK80 & 6540 & Fratercula arctica & 1.6 & 0.9 & 5.1 & 3.4 & 2.7 & 0.1 & 13.8 \\
\hline United Kingdom & UK80 & 220 & Fulmarus glacialis & 1.2 & 1.7 & 0.1 & 0.8 & 1.5 & 1.9 & 7.1 \\
\hline United Kingdom & UK80 & 59 & Gavia sp & 0.0 & 0.0 & 0.0 & 0.0 & 0.0 & 0.0 & 0.0 \\
\hline United Kingdom & UK80 & 2130 & Melanitta nigra & 0.0 & 3.6 & 0.0 & 0.0 & 0.0 & 0.0 & 3.6 \\
\hline United Kingdom & UK80 & 710 & Morus bassanus & 2.4 & 2.2 & 0.3 & 2.7 & 1.2 & 1.8 & 10.6 \\
\hline United Kingdom & UK80 & 720 & Phalacrocorax carbo & 0.0 & 0.0 & 0.0 & 0.0 & 0.0 & 0.0 & 0.0 \\
\hline United Kingdom & UK80 & 2060 & Somoteria mollissima & 0.0 & 0.0 & 0.0 & 0.0 & 0.0 & 0.0 & 0.0 \\
\hline United Kingdom & UK80 & 6110 & Thalasseus sandvicensis & 0.0 & 0.0 & 0.0 & 0.0 & 0.0 & 0.0 & 0.0 \\
\hline United Kingdom & UK80 & 6340 & Uria aalge & 106.8 & 213.7 & 39.2 & 183.8 & 60.0 & 69.8 & 673.3 \\
\hline United Kingdom & UK81 & 6360 & Alca torda & 9.4 & 6.4 & 14.3 & 15.0 & 0.4 & 40.4 & 86.0 \\
\hline United Kingdom & UK81 & 6540 & Fratercula arctica & 2.1 & 0.3 & 0.2 & 0.4 & 0.2 & 6.0 & 9.3 \\
\hline United Kingdom & UK81 & 220 & Fulmarus glacialis & 1.8 & 1.0 & 0.2 & 0.8 & 1.5 & 0.8 & 6.0 \\
\hline United Kingdom & UK81 & 59 & Gavia sp & 0.0 & 0.0 & 0.0 & 0.0 & 0.0 & 0.0 & 0.0 \\
\hline United Kingdom & UK81 & 2130 & Melanitta nigra & 0.0 & 0.0 & 0.0 & 0.0 & 0.0 & 0.0 & 0.0 \\
\hline United Kingdom & UK81 & 710 & Morus bassanus & 1.9 & 4.0 & 0.3 & 1.8 & 0.9 & 3.7 & 12.8 \\
\hline United Kingdom & UK81 & 720 & Phalacrocorax carbo & 0.0 & 0.0 & 0.0 & 0.1 & 0.0 & 0.0 & 0.1 \\
\hline United Kingdom & UK81 & 2060 & Somoteria mollissima & 0.0 & 0.0 & 0.0 & 0.0 & 0.0 & 0.0 & 0.0 \\
\hline United Kingdom & UK81 & 6110 & Thalasseus sandvicensis & 0.0 & 0.0 & 0.0 & 0.0 & 0.0 & 0.0 & 0.0 \\
\hline United Kingdom & UK81 & 6340 & Uria aalge & 126.0 & 101.4 & 137.5 & 82.4 & 69.7 & 252.6 & 769.6 \\
\hline
\end{tabular}




\section{Addendum: Seasonal distribution maps for 19 (sea) bird species.}

On the following pages for each (sea) bird species a six-panel figure is presented showing from top-left to bottom-right the seasonal distribution for season (bimonth) 1-Aug/Sep; 2-Oct/Not; 3-Dec/Jan; 4-

Feb/Mar; 5-Apr/May and 6-Jun/Jul.

The first set is for the International maps for the study area as it overlaps with the EEZs of the following countries: Belgium, United Kingdom, Norway, Denmark, Germany and the Netherlands (Fig 1 thru Fig 18), The second set is for the National Maps, coinciding with the Dutch EEZ (aka NCP for Nederlands Continentaal Plat) (Fig 19 thru Fig 38).

In both cases the species are presented in order of increasing EUring-code as per the table below:

\begin{tabular}{r|lll} 
EURING & SCIENTIFIC NAME & NL NAME & EN NAME \\
\hline $\mathbf{5 9}$ & Gavia sp & Duiker spec. & Diver sp \\
$\mathbf{2 2 0}$ & Fulmarus glacialis & Noordse Stormvogel & Northern Fulmar \\
$\mathbf{7 1 0}$ & Morus bassanus & Jan-van-Gent & Gannet \\
$\mathbf{7 2 0}$ & Phalacrocorax carbo & Aalscholver & Cormorant \\
$\mathbf{2 0 6 0}$ & Somateria mollissima & Eidereend & Eider duck \\
$\mathbf{2 1 3 0}$ & Melanitta nigra & Zw. Zeeëend & Common Scoter \\
$\mathbf{5 6 7 0}$ & Stercorarius parasiticus & Kleine Jager & Arctic Skua \\
$\mathbf{5 6 9 0}$ & Stercorarius skua & Grote Jager & Great Skua \\
$\mathbf{5 7 8 0}$ & Hydrocoloeus minutus & Dwergmeeuw & Little Gull \\
$\mathbf{5 9 1 0}$ & Larus fuscus & Kleine Mantelmeeuw & Lesser black-backed Gull \\
$\mathbf{5 9 2 0}$ & Larus argentatus & Zilvermeeuw & Herring Gull \\
$\mathbf{6 0 0 0}$ & Larus marinus & Grote Mantelmeeuw & Great Black-backed Gull \\
$\mathbf{6 0 2 0}$ & Rissa tridactyla & Drieeteenmeeuw & Kittiwake \\
$\mathbf{6 1 1 0}$ & Thalasseus sandvicensis & Grote Stern & Sandwich Tern \\
$\mathbf{6 1 6 9}$ & Sterna paradisaea+hirundo & "Noordse Dief" & "Commic Tern" \\
$\mathbf{6 3 4 0}$ & Uria aalge & Zeekoet & Common Guillemot \\
$\mathbf{6 3 6 0}$ & Alca torda & Alk & Razorbill \\
$\mathbf{6 5 4 0}$ & Fratercula arctica & Papegaaiduiker & Atlantic Puffin \\
$\mathbf{1 5 8 2 0}$ & Sturnus vulgaris & Spreeuw & Common Starling \\
& & & \\
& & &
\end{tabular}




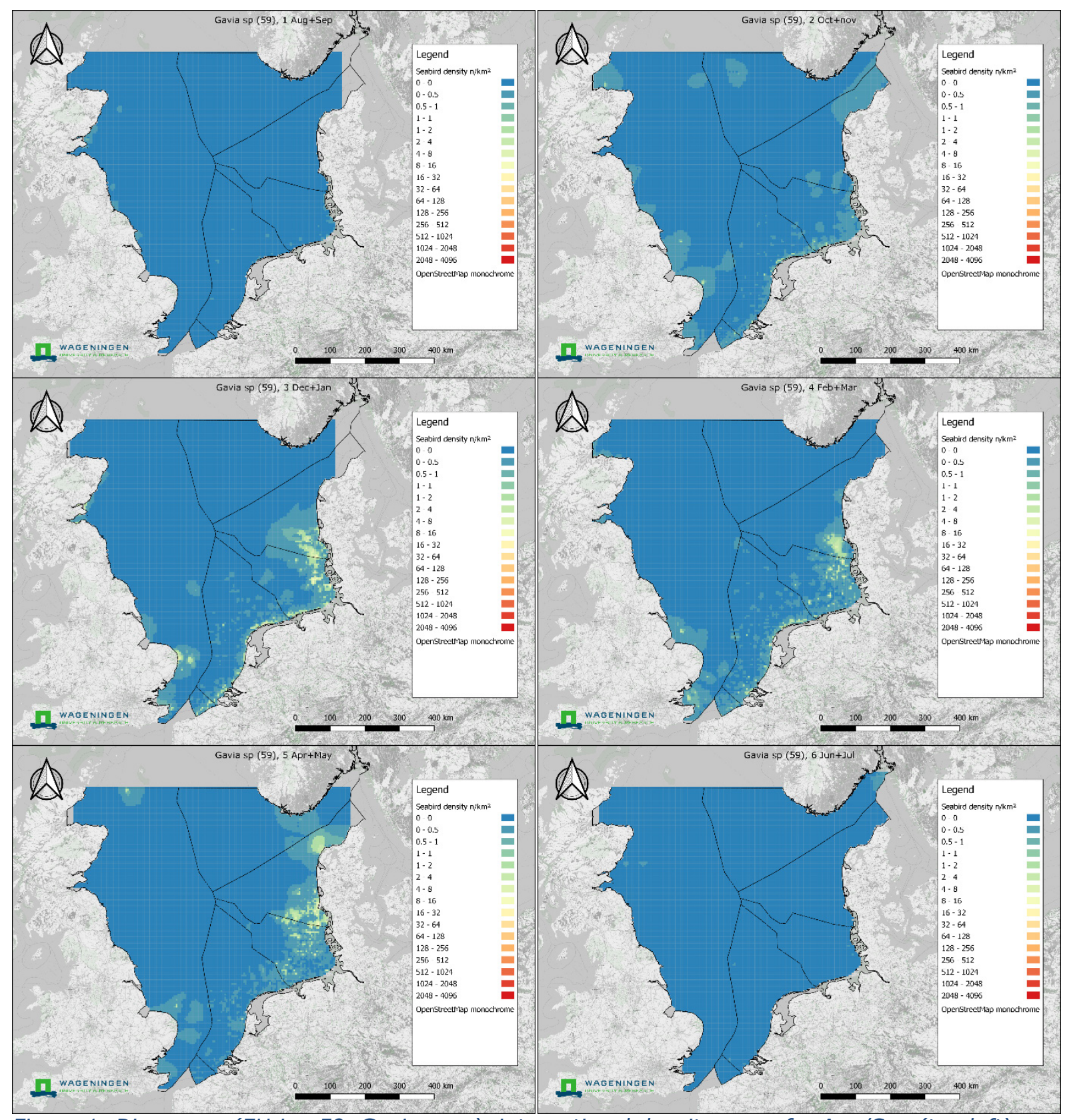

Figure 1: Diver spec (EUring 59, Gavia spec). international density maps for Aug/Sep (top left); Oct/Nov (top right), Dec/Jan (middle left), Feb/Mar (middle right), Apr/May (lower left) and Jun/Jul (lower right). 


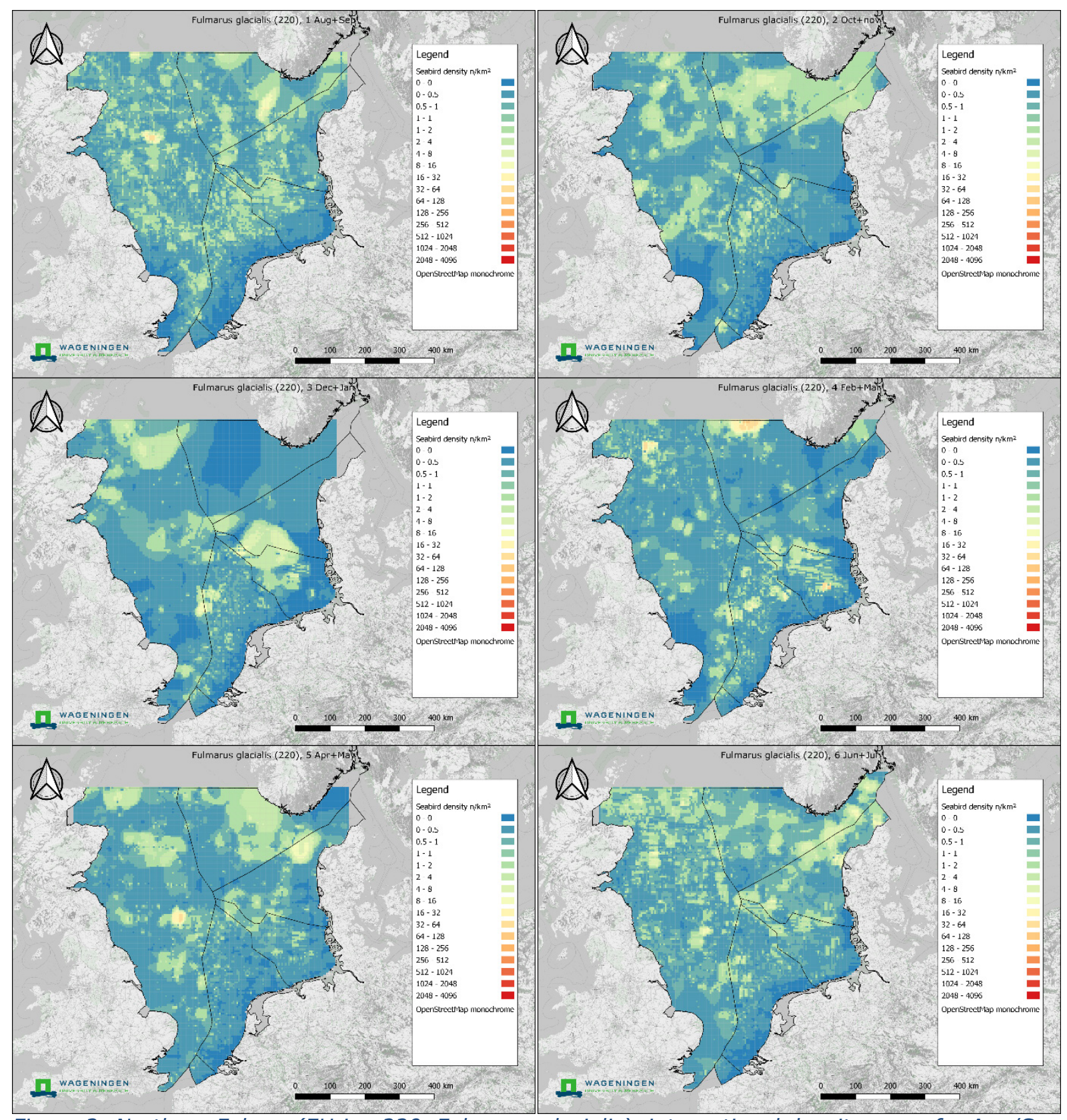

Figure 2: Northern Fulmar (EUring 220, Fulmarus glacialis), international density maps for Aug/Sep (top left); Oct/Nov (top right), Dec/Jan (middle left), Feb/Mar (middle right), Apr/May (lower left) and Jun/Jul (lower right). 


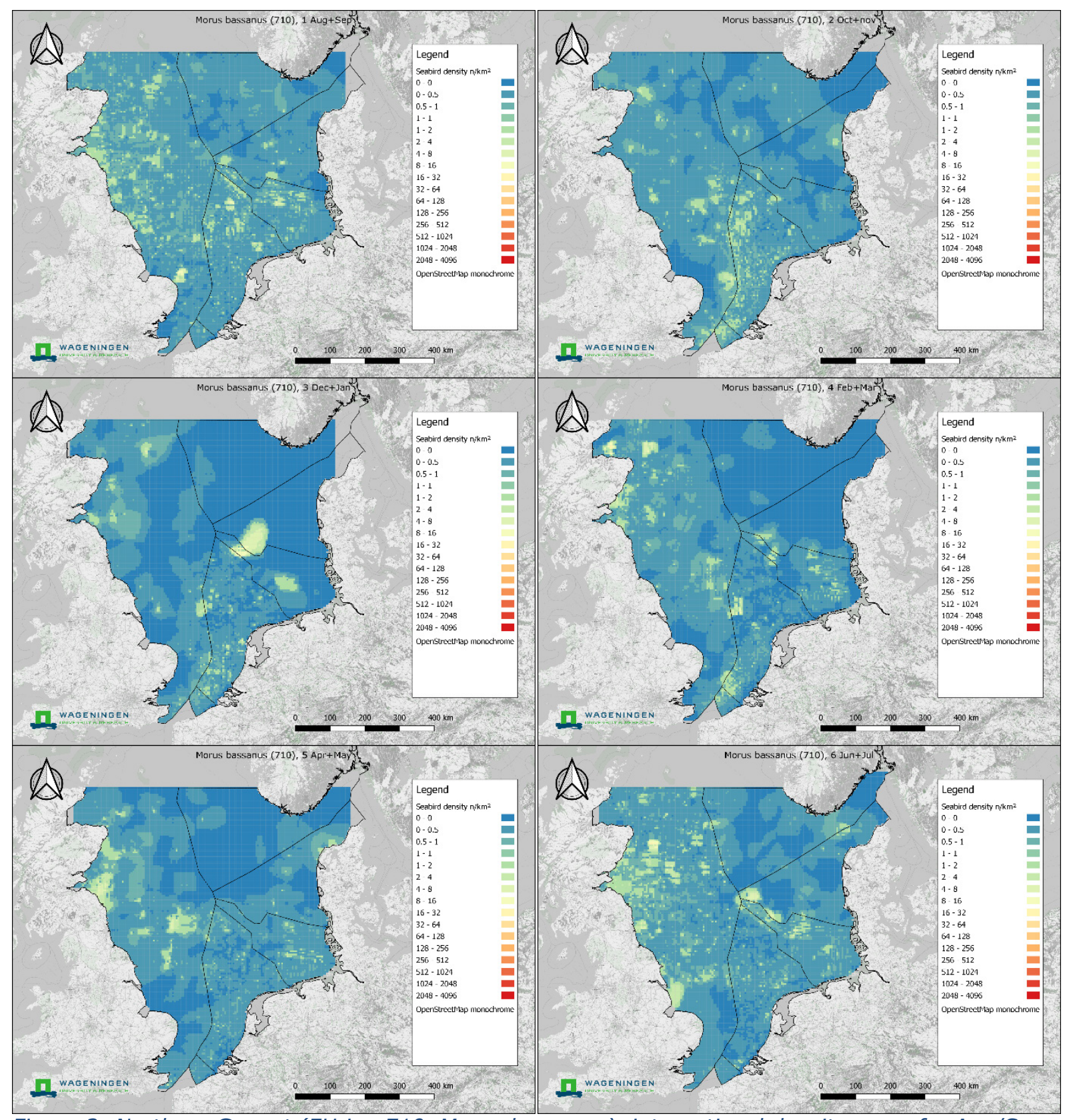

Figure 3: Northern Gannet (EUring 710, Morus bassanus). international density maps for Aug/Sep (top left); Oct/Nov (top right), Dec/Jan (middle left), Feb/Mar (middle right), Apr/May (lower left) and Jun/Jul (lower right). 


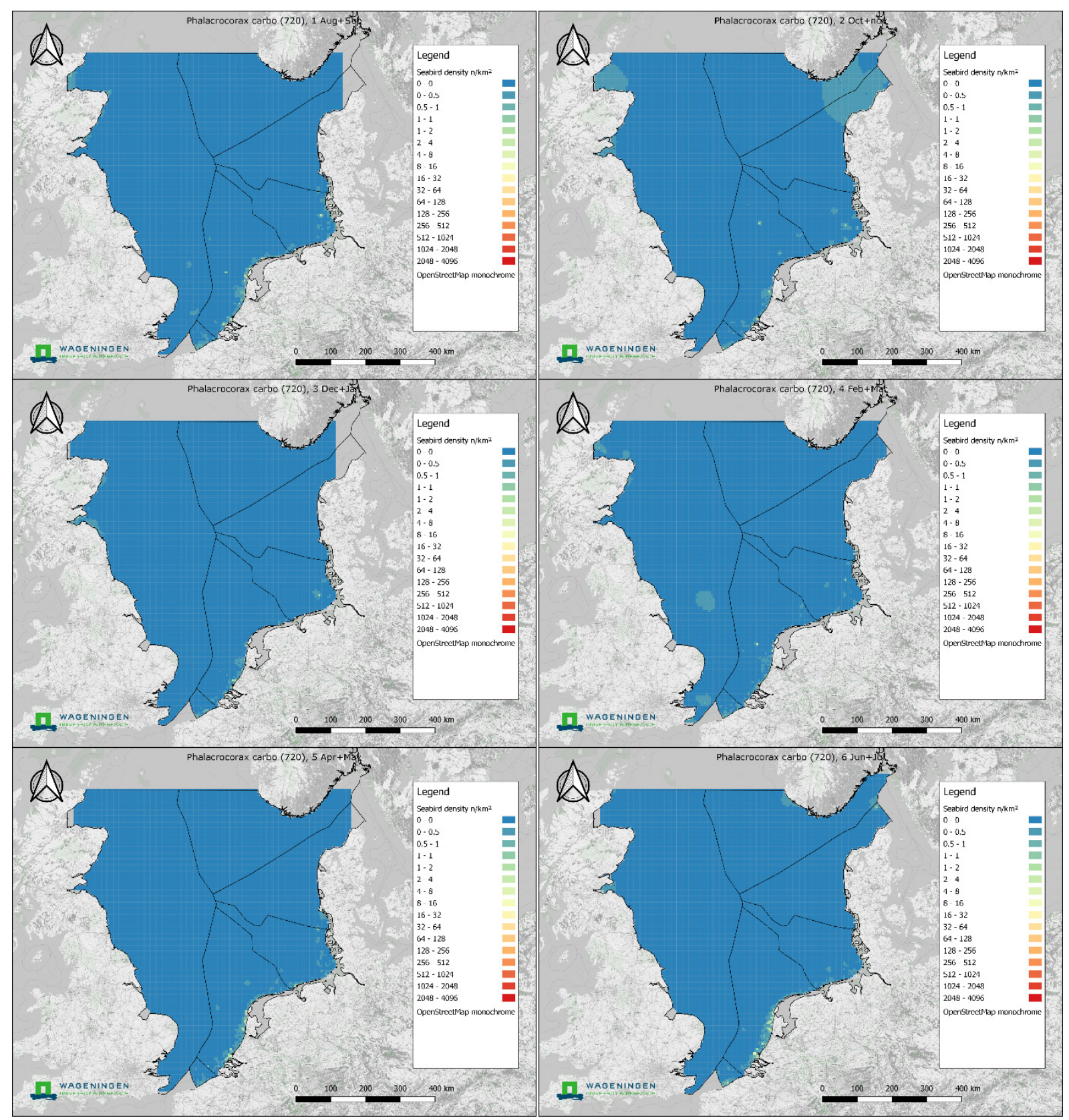

Figure 4: Cormorant (EUring 720, Phalacrorocax carbo). international density maps for Aug/Sep (top left); Oct/Nov (top right), Dec/Jan (middle left), Feb/Mar (middle right), Apr/May (lower left) and Jun/Jul (lower right). 


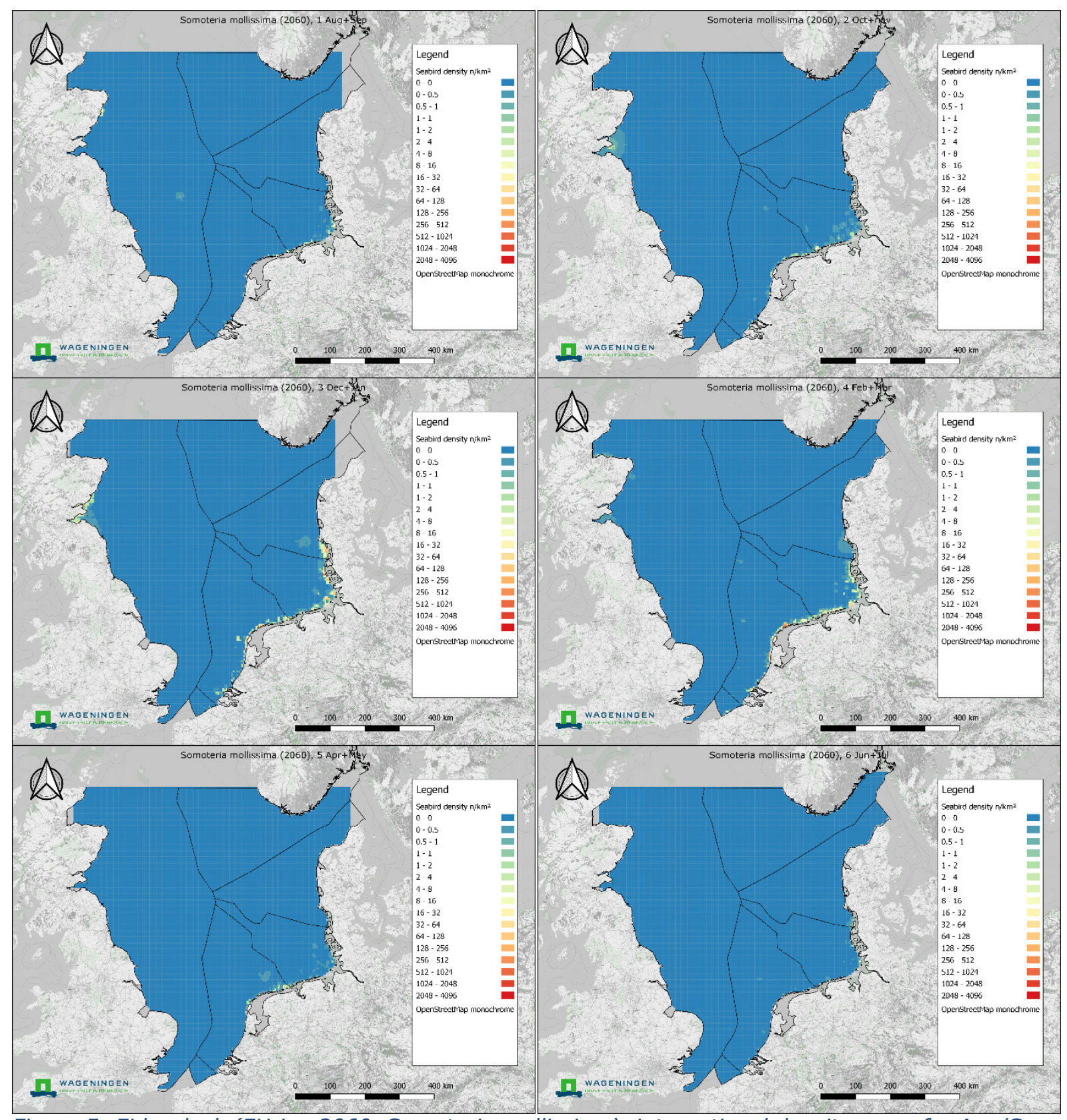

Figure 5: Eider duck (EUring 2060, Somateria mollissima). international density maps for Aug/Sep (top left); Oct/Nov (top right), Dec/Jan (middle left), Feb/Mar (middle right), Apr/May (lower left) and Jun/Jul (lower right). 


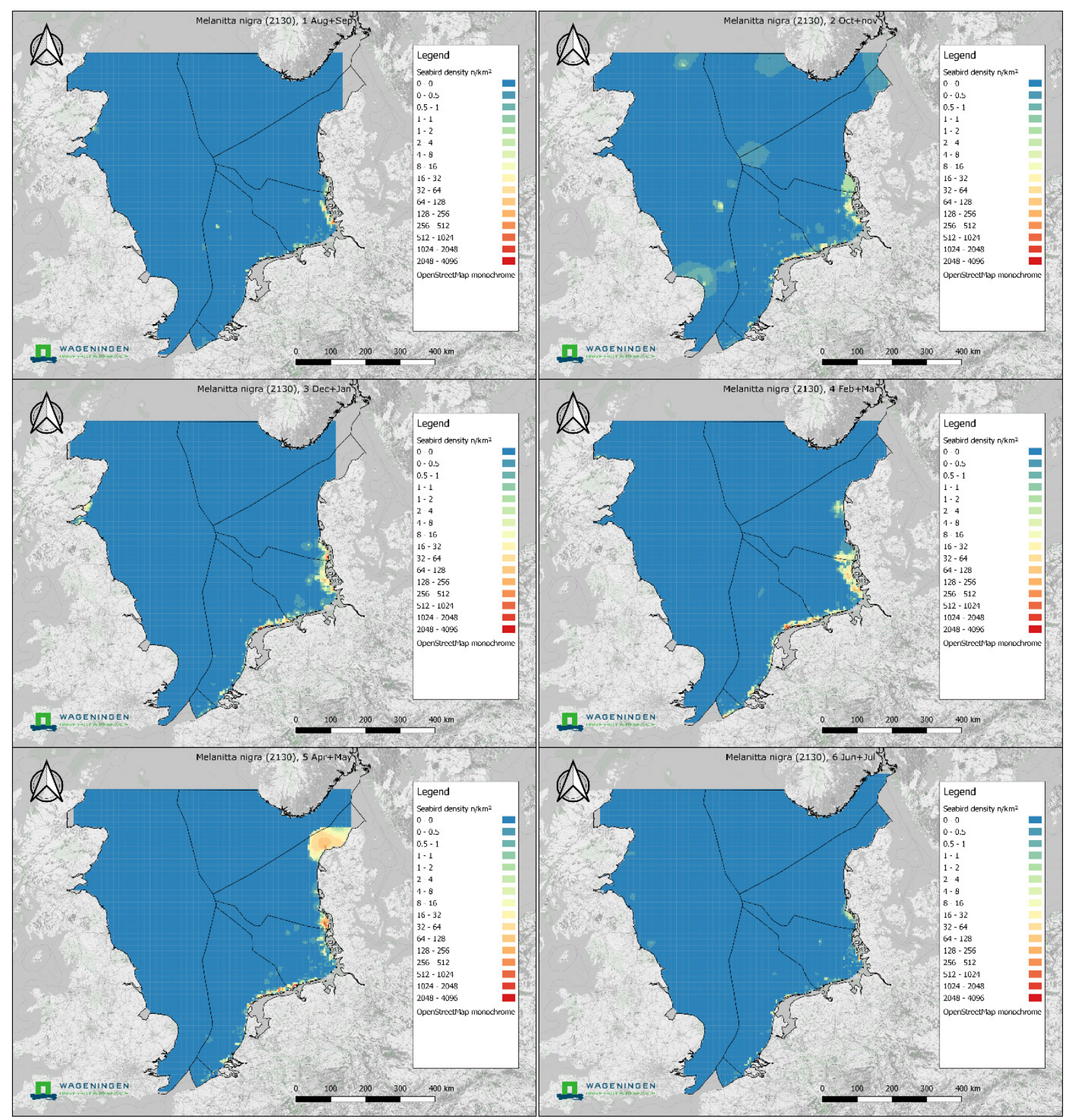

Figure 6: Common Scoter (EUring 2130, Melanitta nigra). international density maps for Aug/Sep (top left); Oct/Nov (top right), Dec/Jan (middle left), Feb/Mar (middle right), Apr/May (lower left) and Jun/Jul (lower right). 


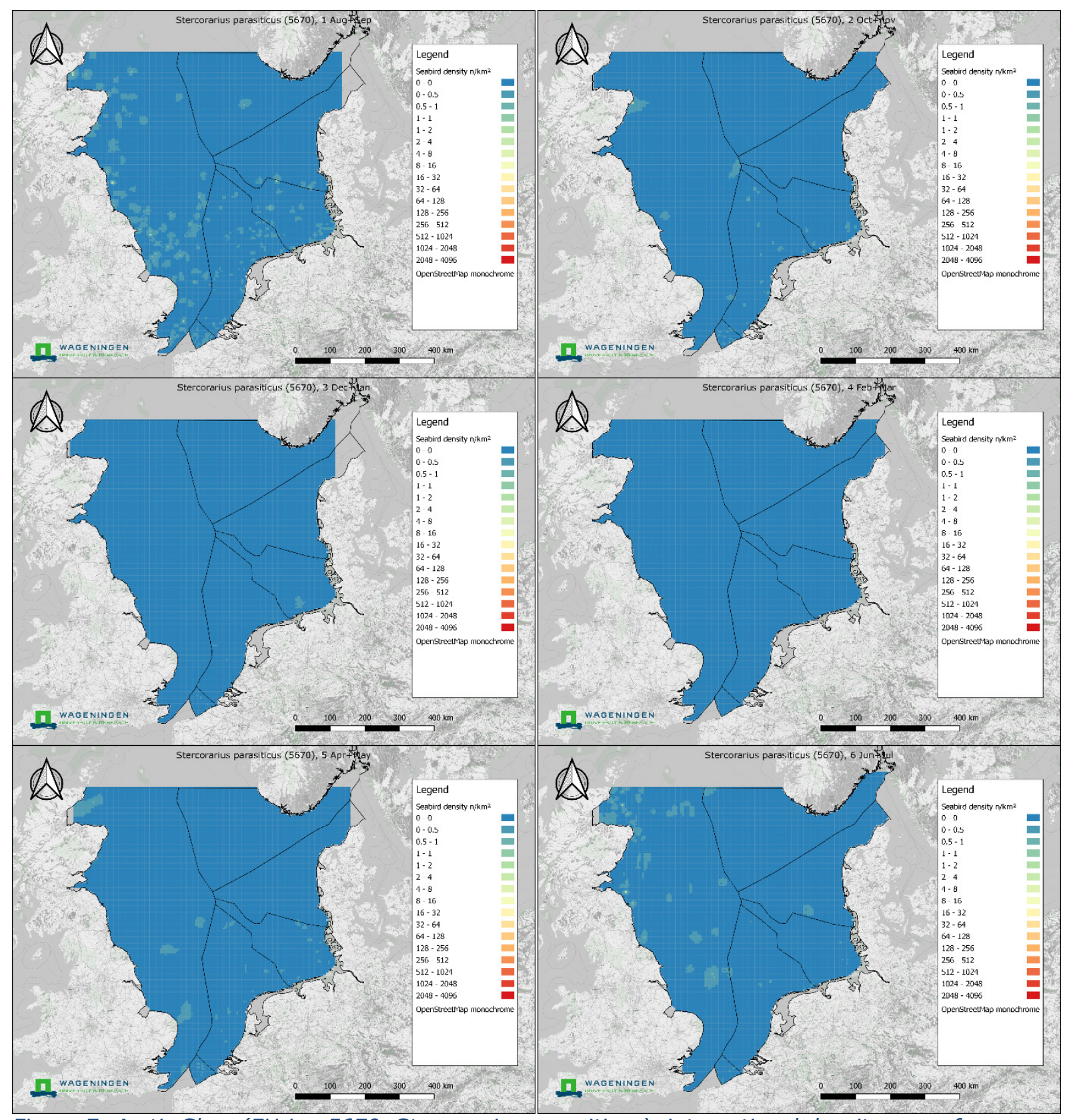

Figure 7: Arctic Skua (EUring 5670, Stercorarius parasiticus). international density maps for Aug/Sep (top left); Oct/Nov (top right), Dec/Jan (middle left), Feb/Mar (middle right), Apr/May (lower left) and Jun/Jul (lower right). 


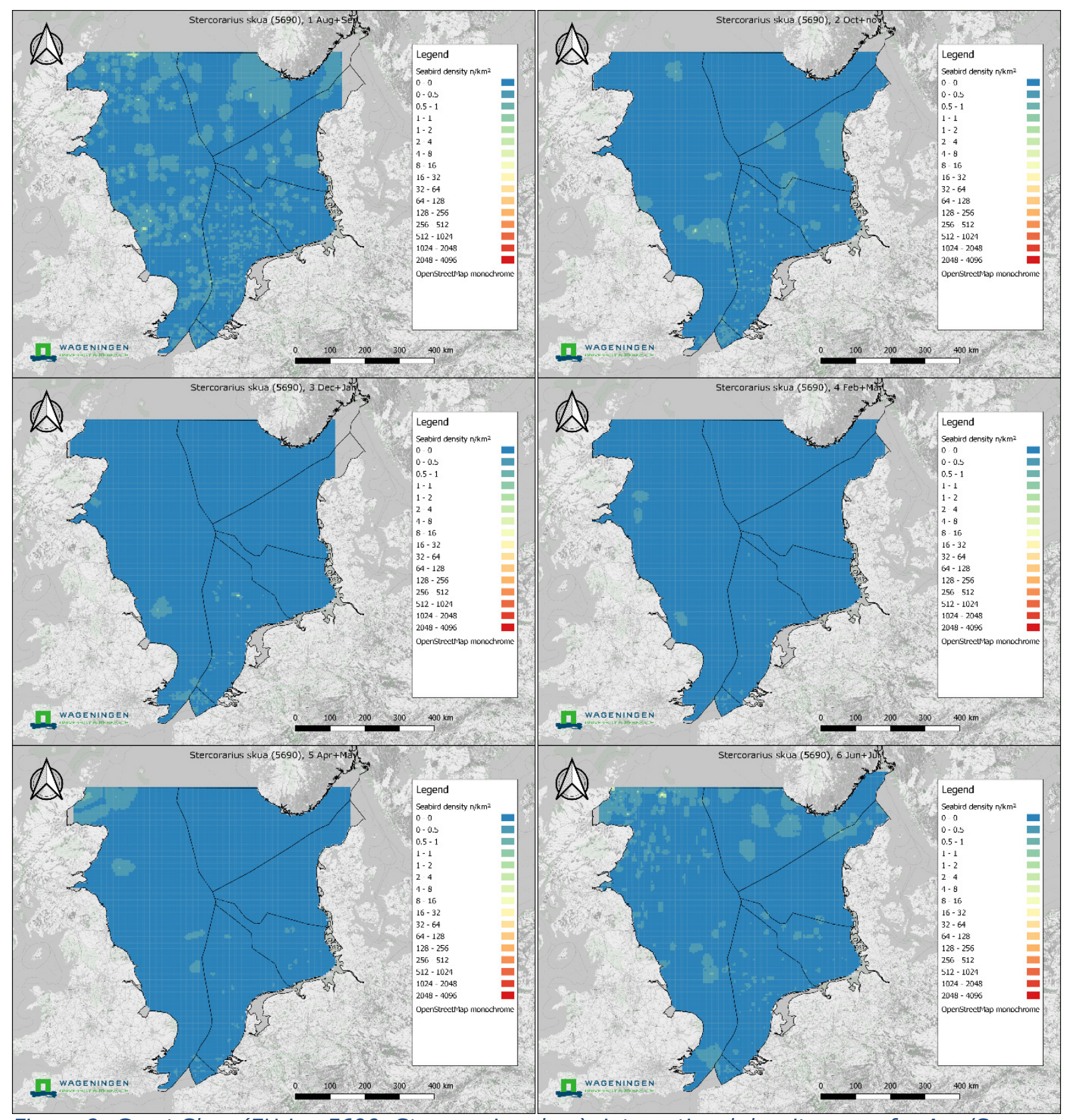

Figure 8: Great Skua (EUring 5690, Stercorarius skua). international density maps for Aug/Sep (top left); Oct/Nov (top right), Dec/Jan (middle left), Feb/Mar (middle right), Apr/May (lower left) and Jun/Jul (lower right). 


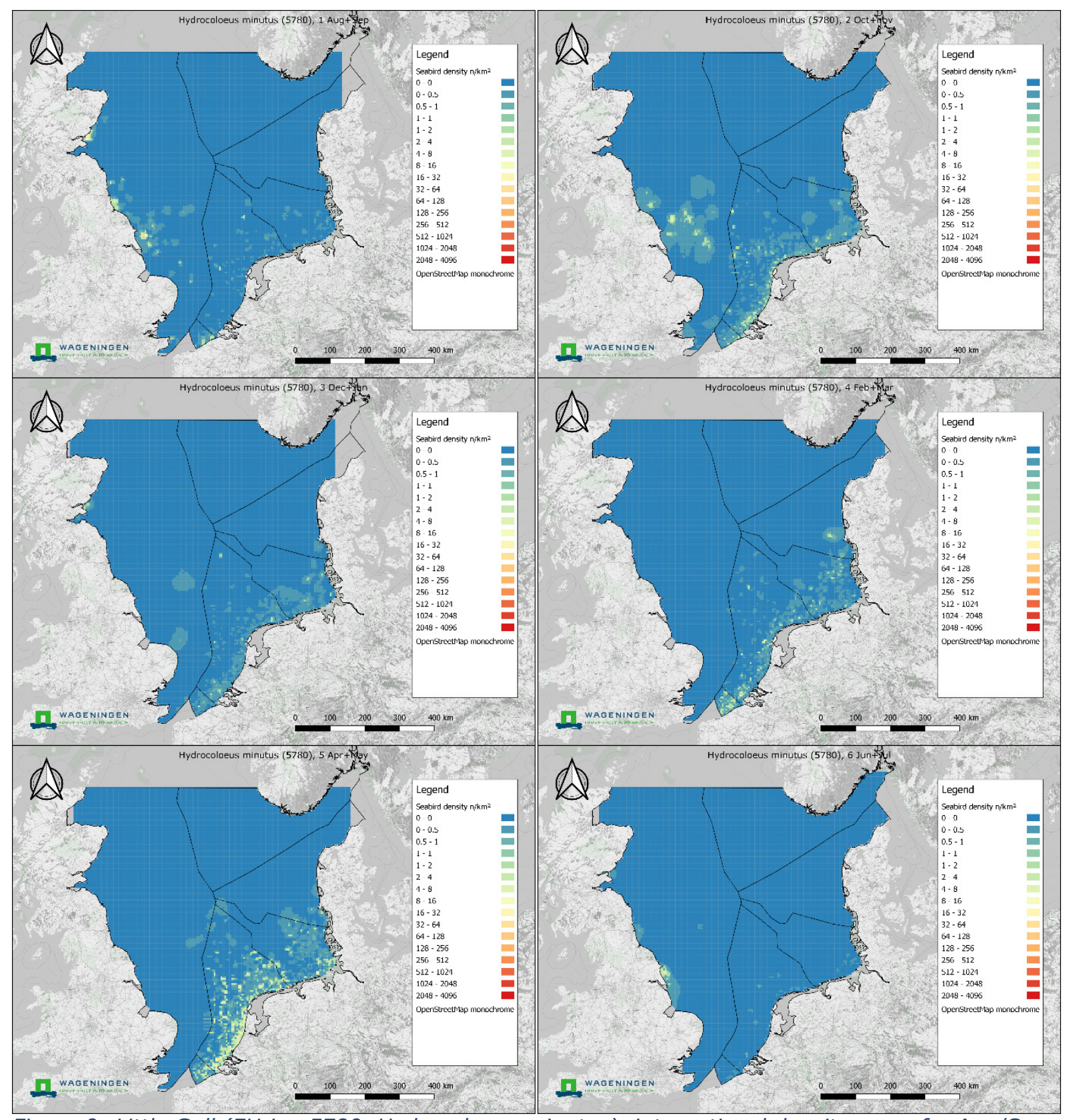

Figure 9: Little Gull (EUring 5780, Hydrocoloeus minutus). international density maps for Aug/Sep (top left); Oct/Nov (top right), Dec/Jan (middle left), Feb/Mar (middle right), Apr/May (lower left) and Jun/Jul (lower right). 


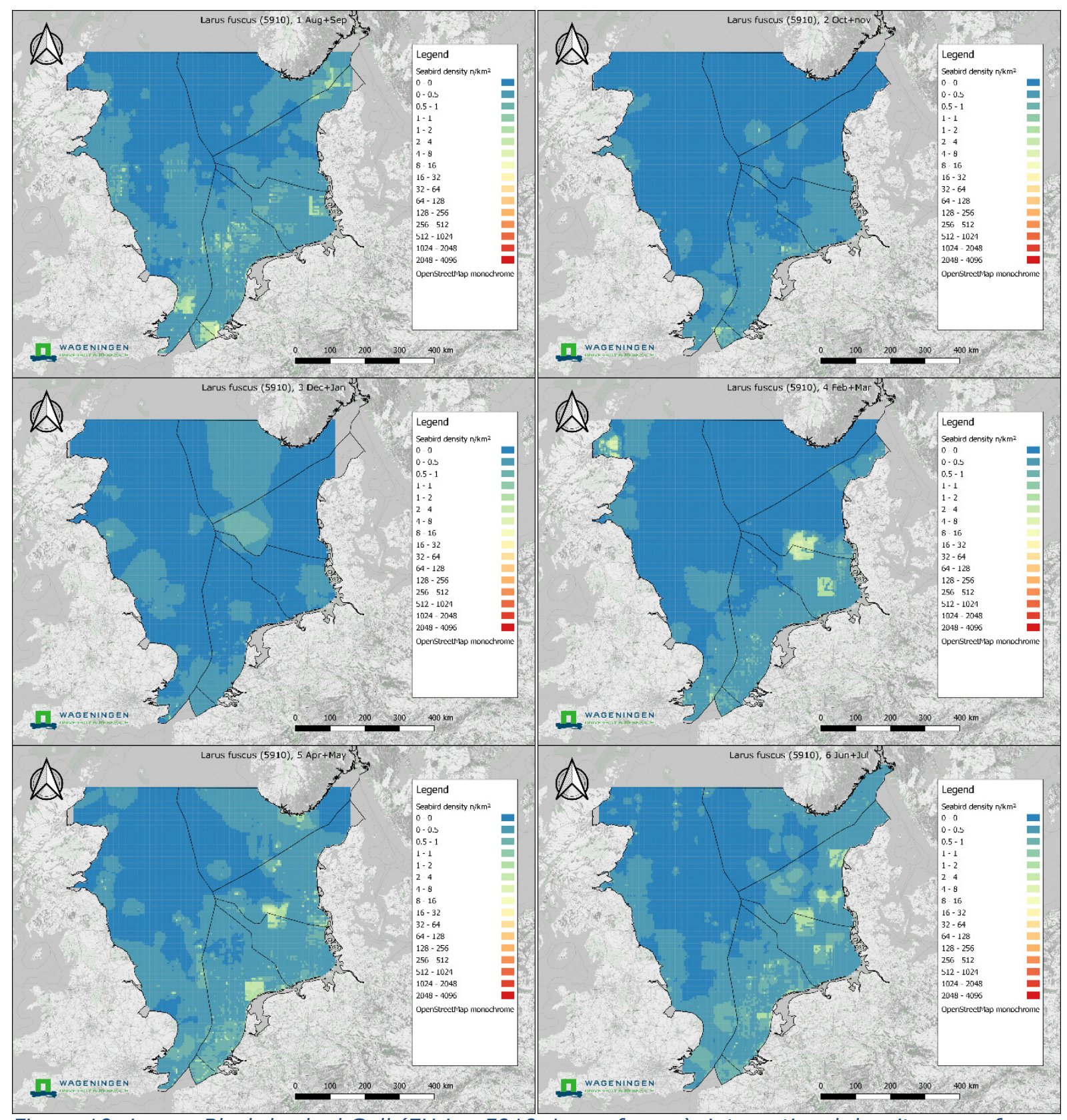

Figure 10: Lesser Black-backed Gull (EUring 5910, Larus fuscus). international density maps for Aug/Sep (top left); Oct/Nov (top right), Dec/Jan (middle left), Feb/Mar (middle right), Apr/May (lower left) and Jun/Jul (lower right). 


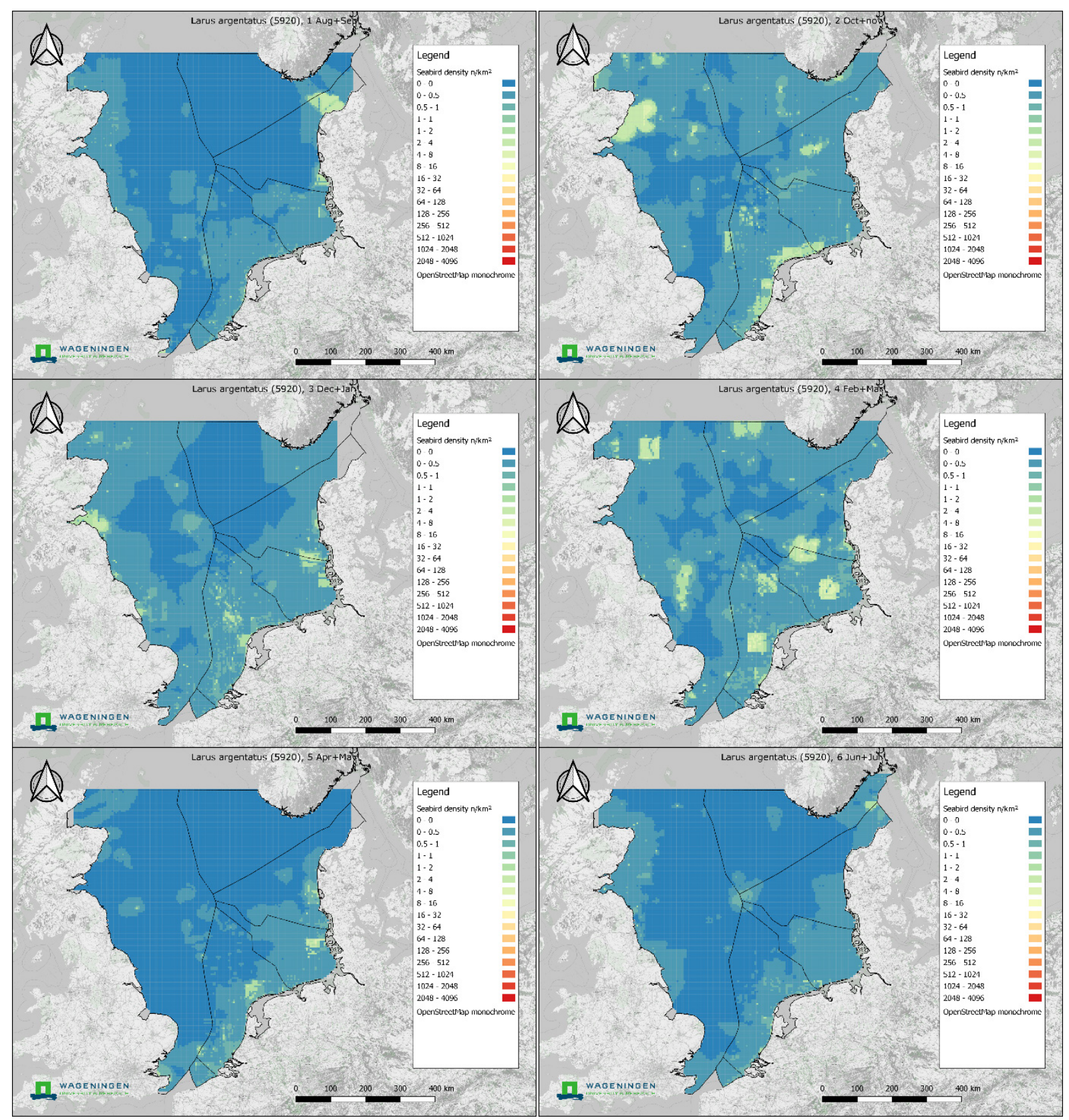

Figure 11: Herring Gull (EUring 5920, Larus argentatus). international density maps for Aug/Sep (top left); Oct/Nov (top right), Dec/Jan (middle left), Feb/Mar (middle right), Apr/May (lower left) and Jun/Jul (lower right). 


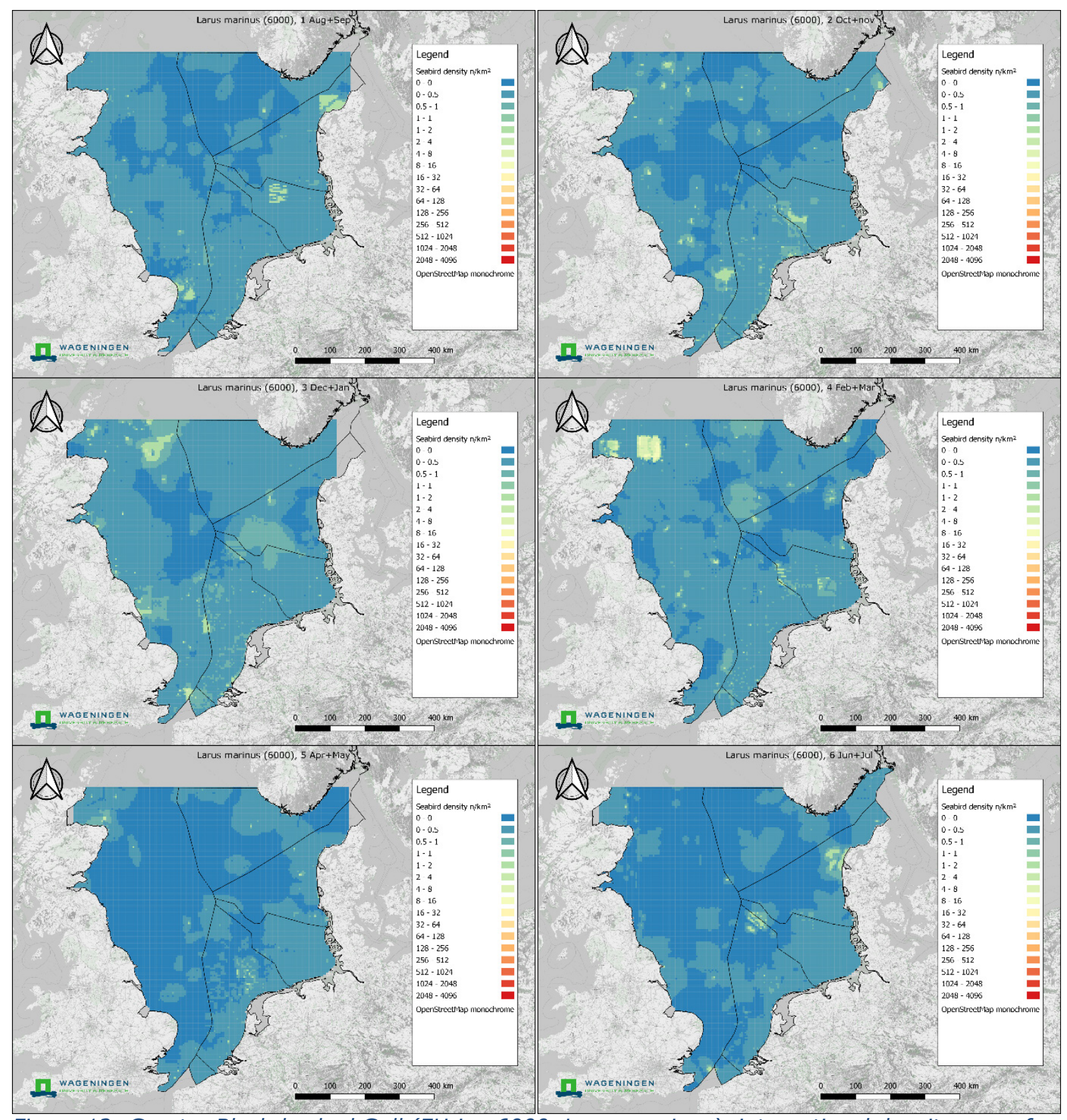

Figure 12: Greater Black-backed Gull (EUring 6000, Larus marinus), international density maps for Aug/Sep (top left); Oct/Nov (top right), Dec/Jan (middle left), Feb/Mar (middle right), Apr/May (lower left) and Jun/Jul (lower right). 


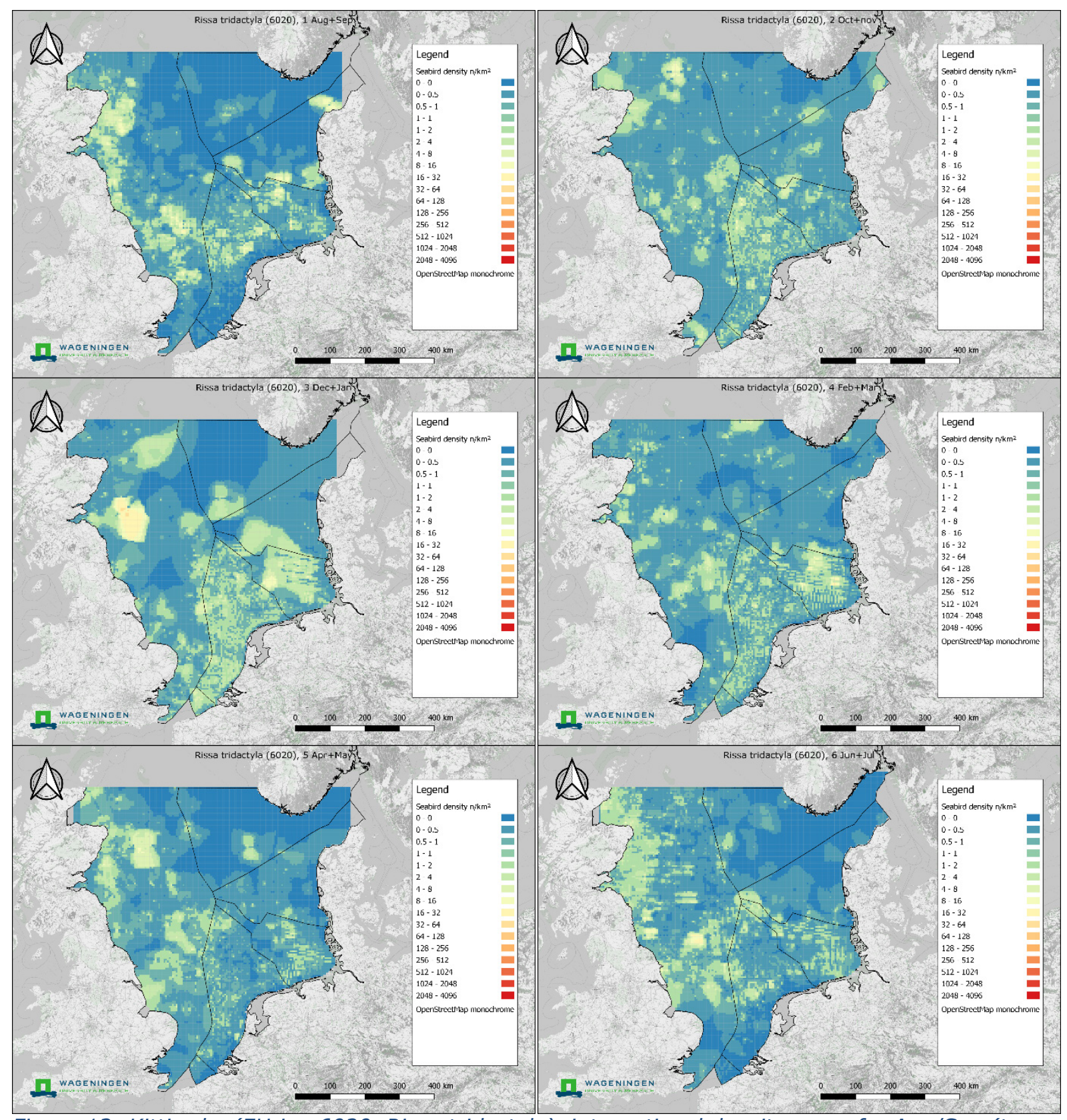

Figure 13: Kittiwake (EUring 6020, Rissa tridactyla). international density maps for Aug/Sep (top left); Oct/Nov (top right), Dec/Jan (middle left), Feb/Mar (middle right), Apr/May (lower left) and Jun/Jul (lower right). 


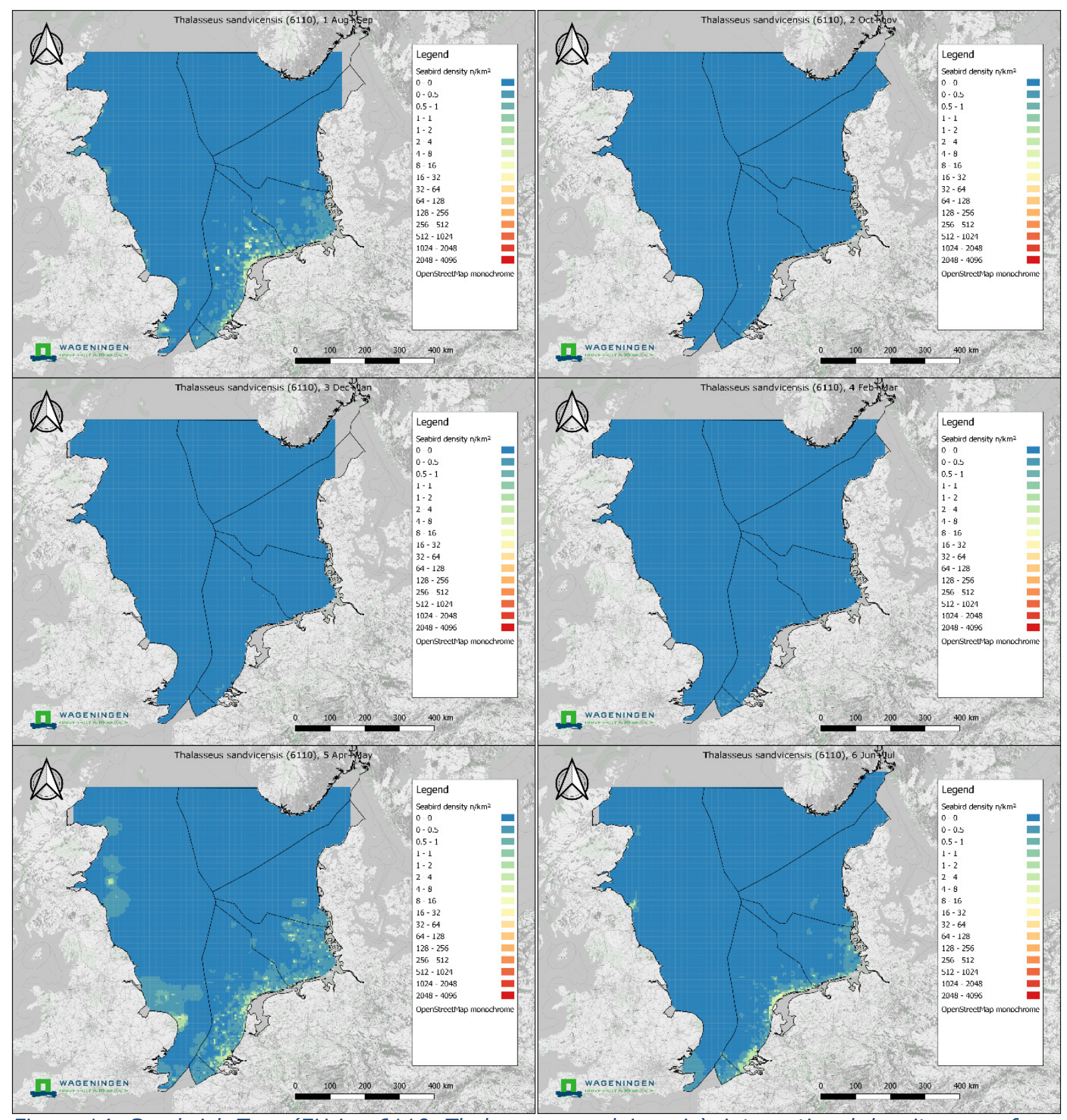

Figure 14: Sandwich Tern (EUring 6110, Thalasseus sandvicensis). international density maps for Aug/Sep (top left); Oct/Nov (top right), Dec/Jan (middle left), Feb/Mar (middle right), Apr/May (lower left) and Jun/Jul (lower right). 


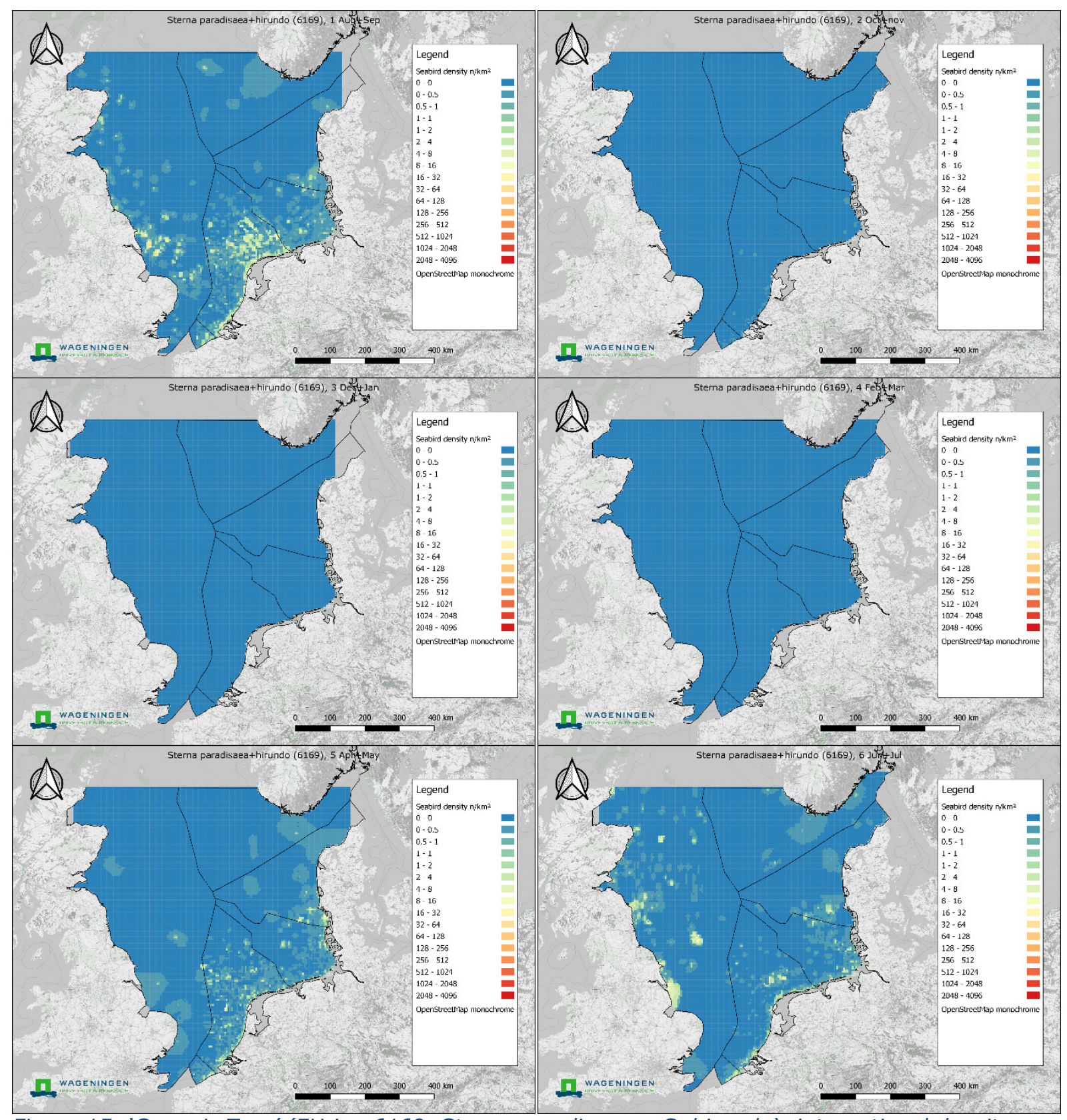

Figure 15: 'Commic Tern' (EUring 6169, Sterna paradiseae + S. hirundo). international density maps for Aug/Sep (top left); Oct/Nov (top right), Dec/Jan (middle left), Feb/Mar (middle right), Apr/May (lower left) and Jun/Jul (lower right). 


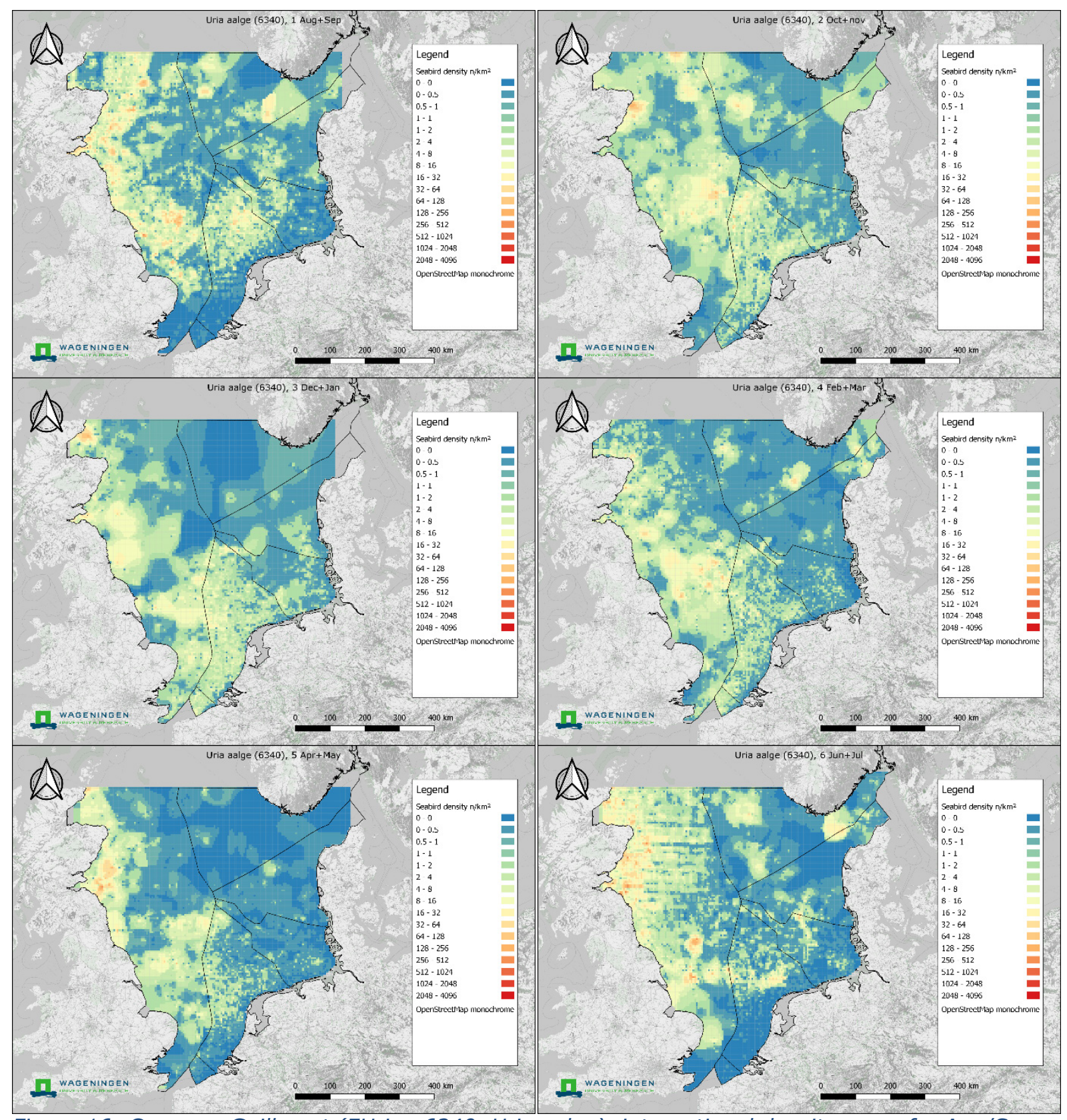

Figure 16: Common Guillemot (EUring 6340, Uria aalge). international density maps for Aug/Sep (top left); Oct/Nov (top right), Dec/Jan (middle left), Feb/Mar (middle right), Apr/May (lower left) and Jun/Jul (lower right). 


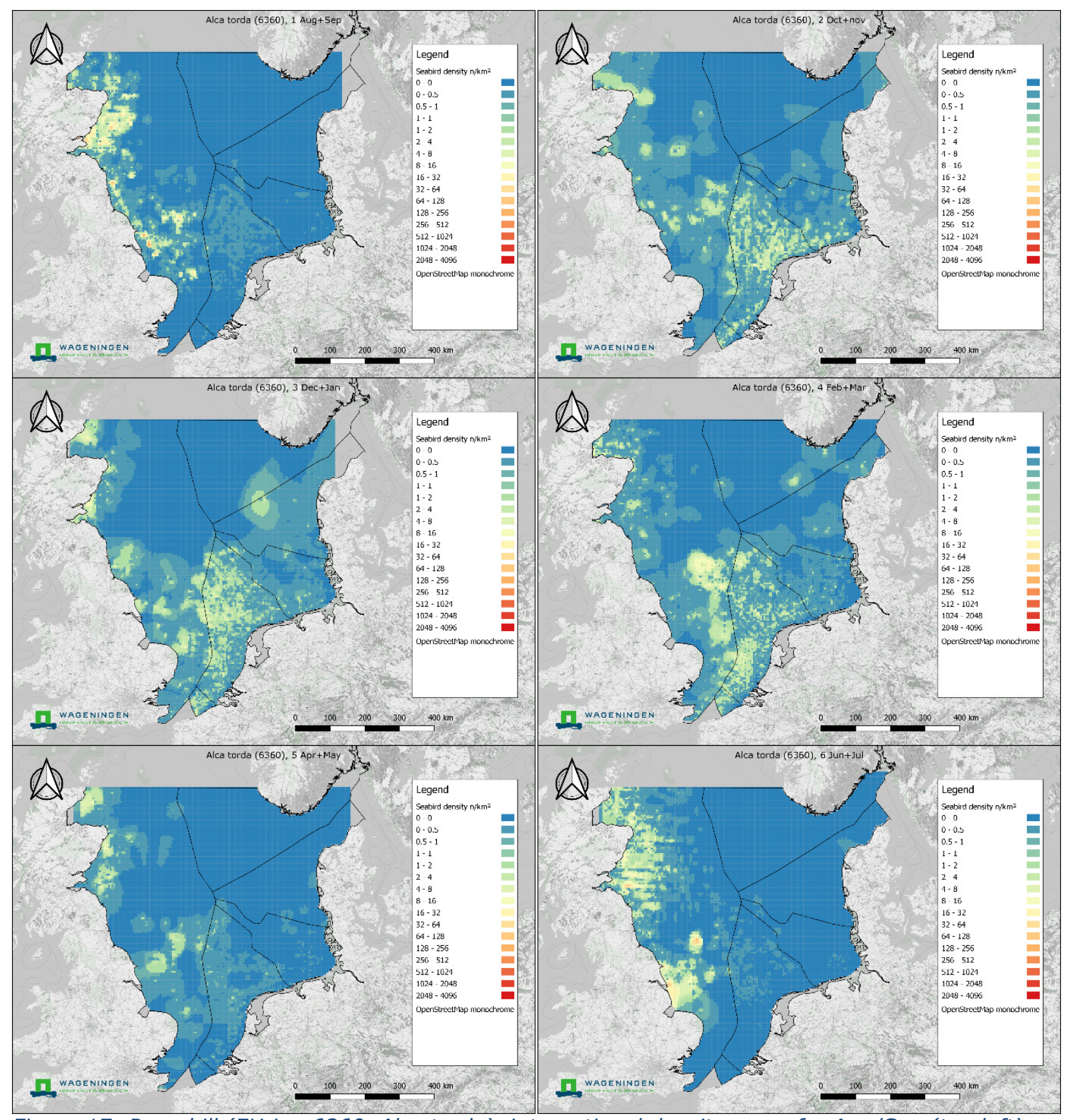

Figure 17: Razorbill (EUring 6360, Alca torda). international density maps for Aug/Sep (top left); Oct/Nov (top right), Dec/Jan (middle left), Feb/Mar (middle right), Apr/May (lower left) and Jun/Jul (lower right). 


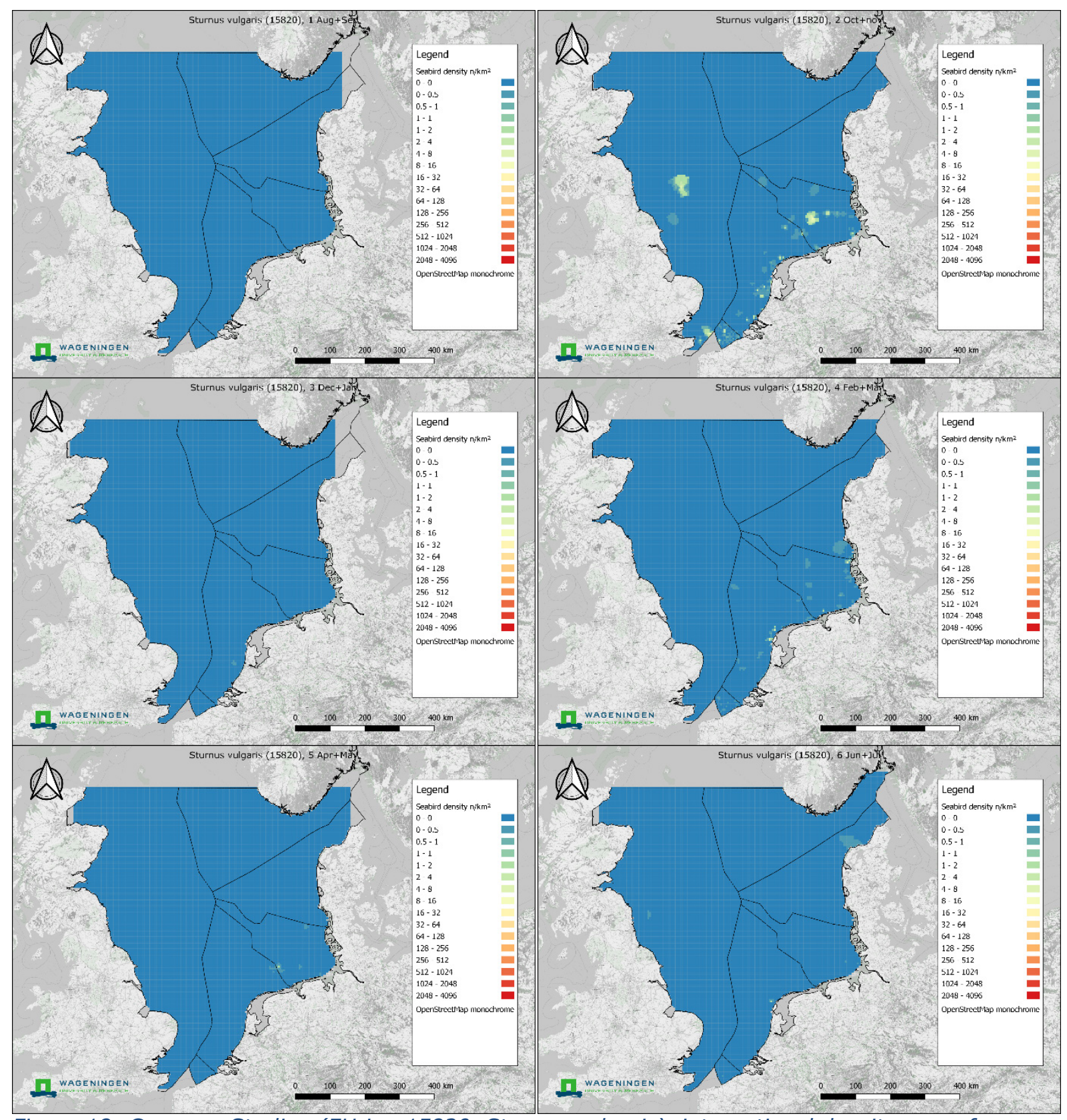

Figure 18: Common Starling (EUring 15820, Sturnus vulgaris). international density maps for Aug/Sep (top left); Oct/Nov (top right), Dec/Jan (middle left), Feb/Mar (middle right), Apr/May (lower left) and Jun/Jul (lower right). 


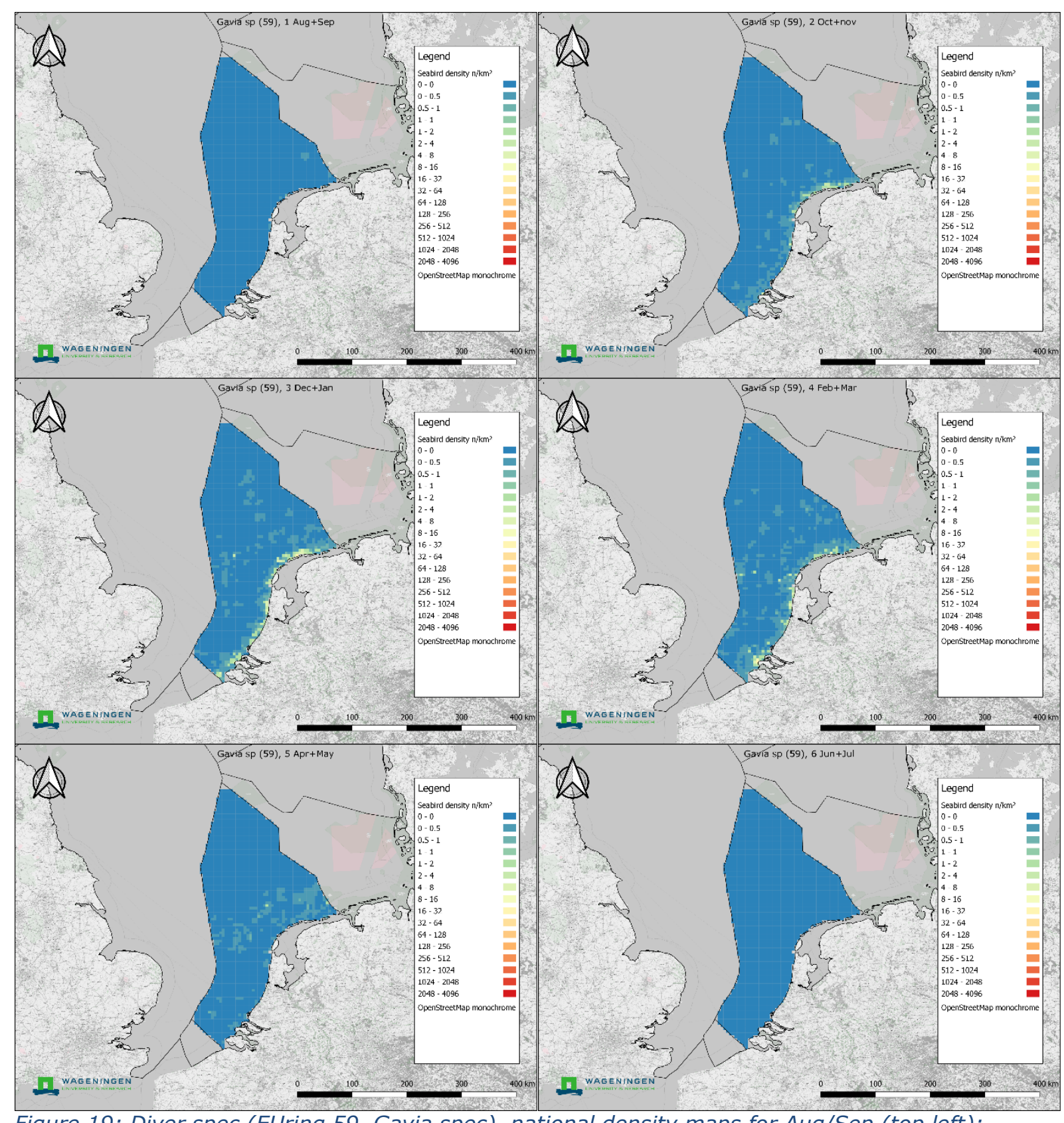

Figure 19: Diver spec (EUring 59, Gavia spec). national density maps for Aug/Sep (top left); Oct/Nov (top right), Dec/Jan (middle left), Feb/Mar (middle right), Apr/May (lower left) and Jun/Jul (lower right). 


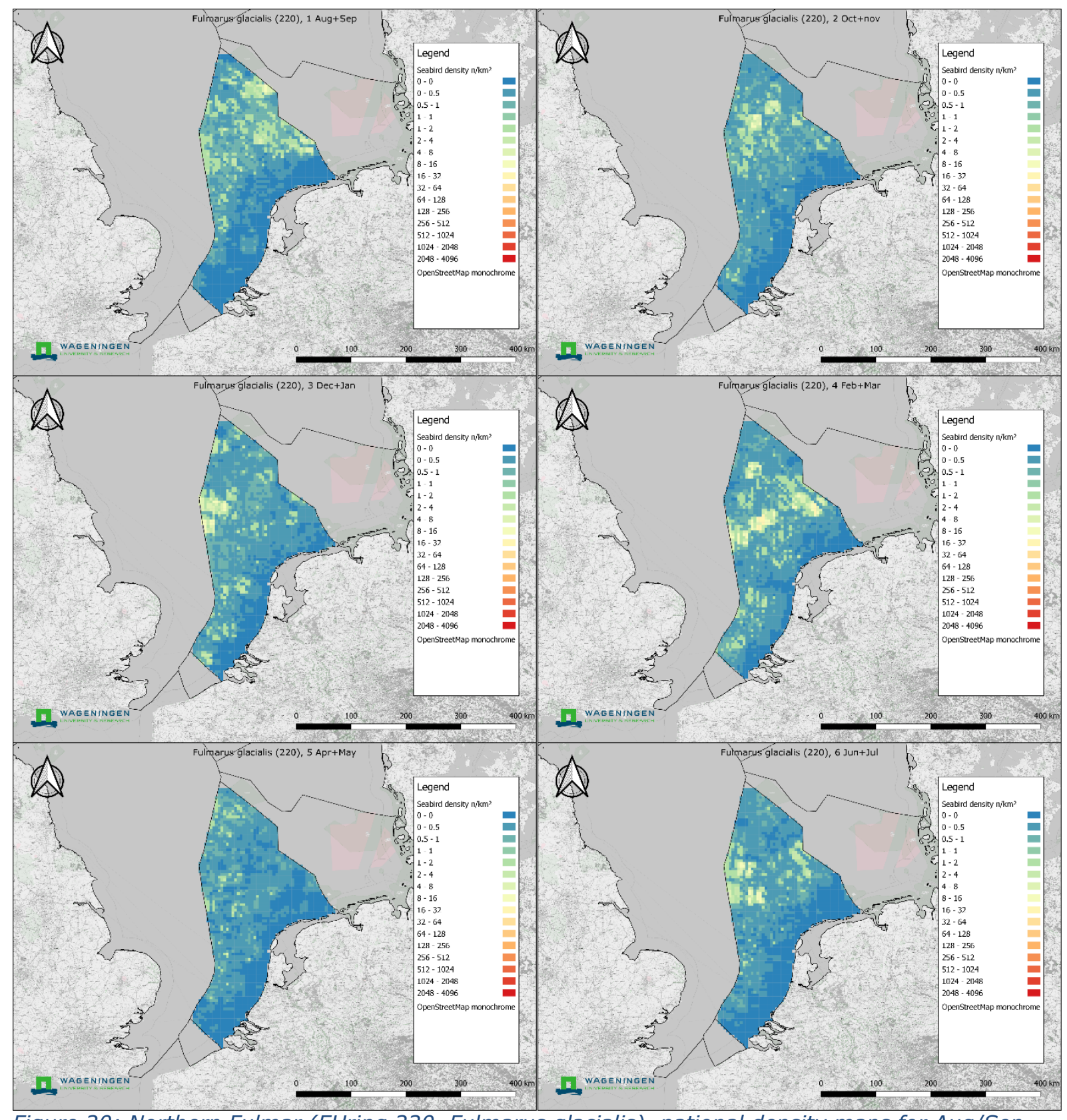

Figure 20: Northern Fulmar (EUring 220, Fulmarus glacialis). national density maps for Aug/Sep (top left); Oct/Nov (top right), Dec/Jan (middle left), Feb/Mar (middle right), Apr/May (lower left) and Jun/Jul (lower right). 


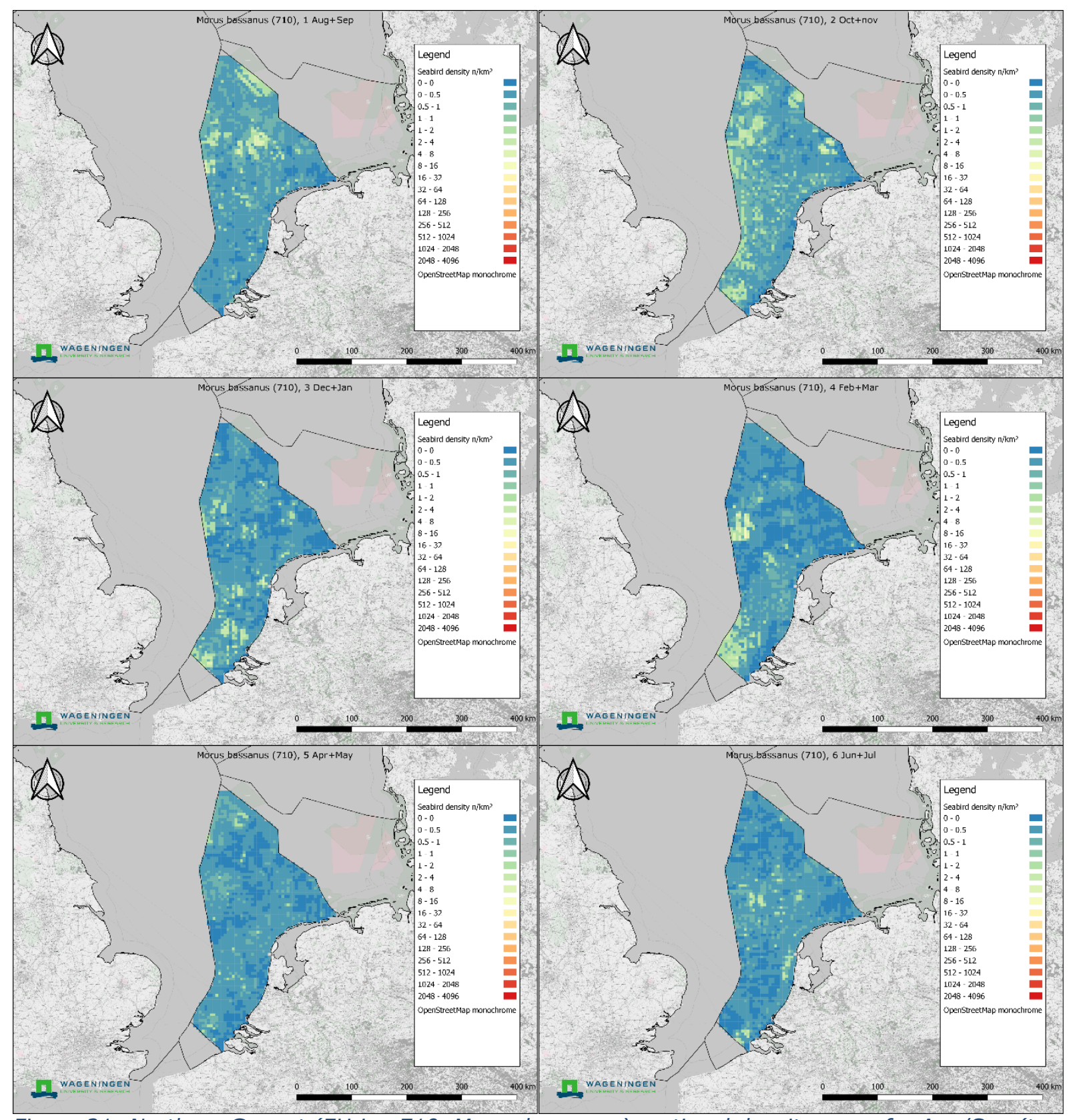

Figure 21: Northern Gannet (EUring 710, Morus bassanus). national density maps for Aug/Sep (top left); Oct/Nov (top right), Dec/Jan (middle left), Feb/Mar (middle right), Apr/May (lower left) and Jun/Jul (lower right). 


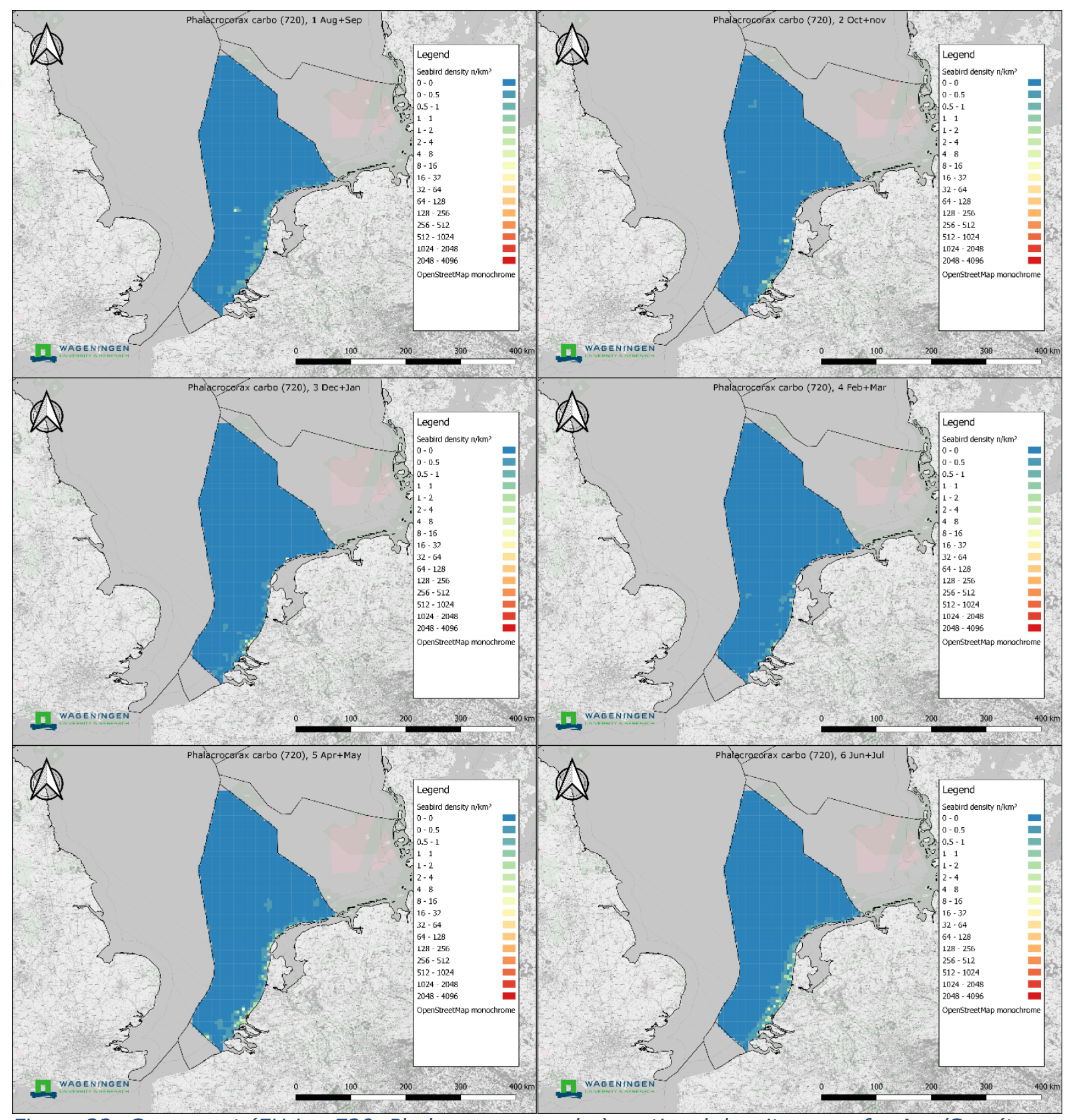

Figure 22: Cormorant (EUring 720, Phalacrocorax carbo). national density maps for Aug/Sep (top left); Oct/Nov (top right), Dec/Jan (middle left), Feb/Mar (middle right), Apr/May (lower left) and Jun/Jul (lower right). 


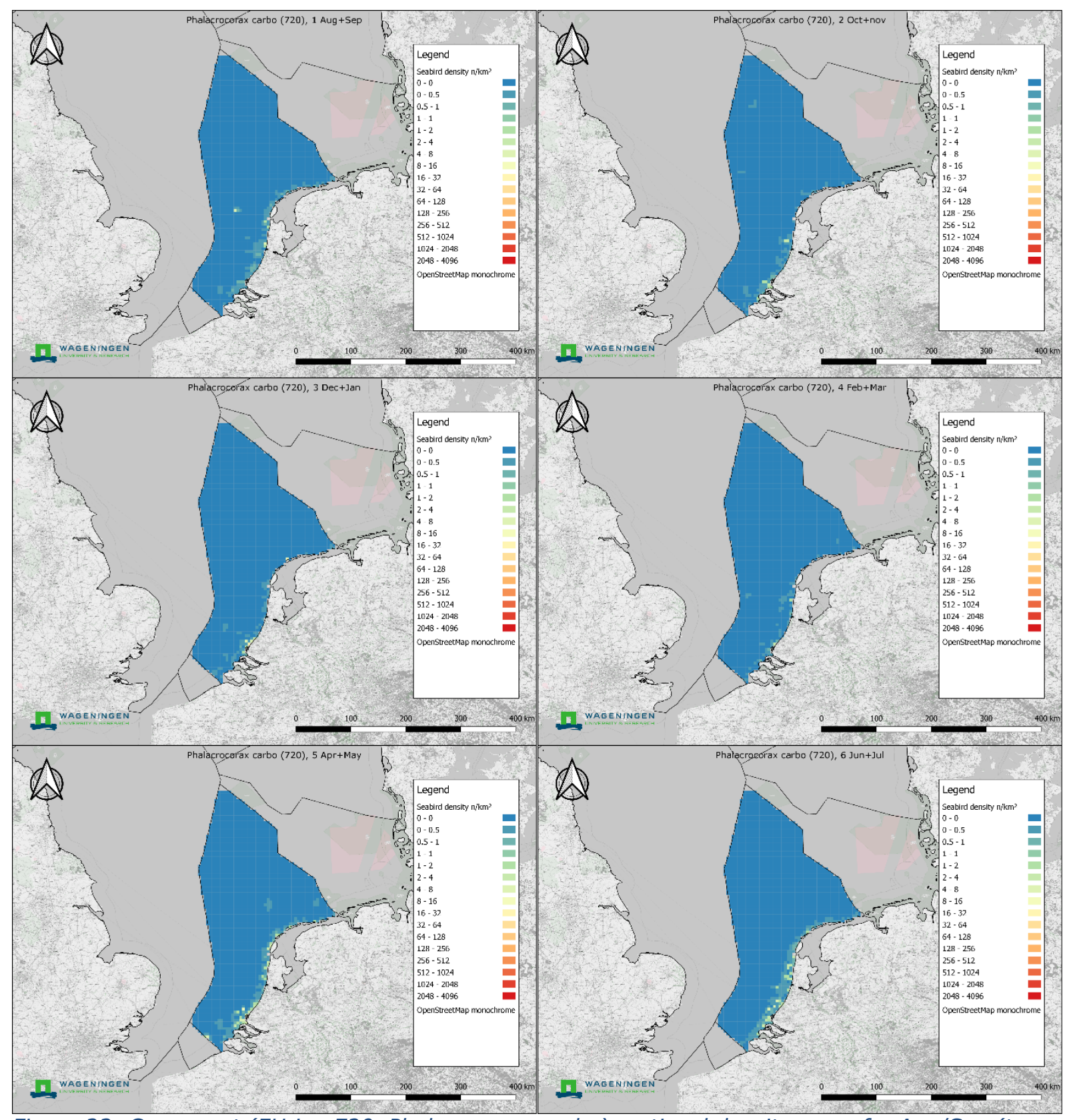

Figure 23: Cormorant (EUring 720, Phalacrocorax carbo). national density maps for Aug/Sep (top left); Oct/Nov (top right), Dec/Jan (middle left), Feb/Mar (middle right), Apr/May (lower left) and Jun/Jul (lower right). 


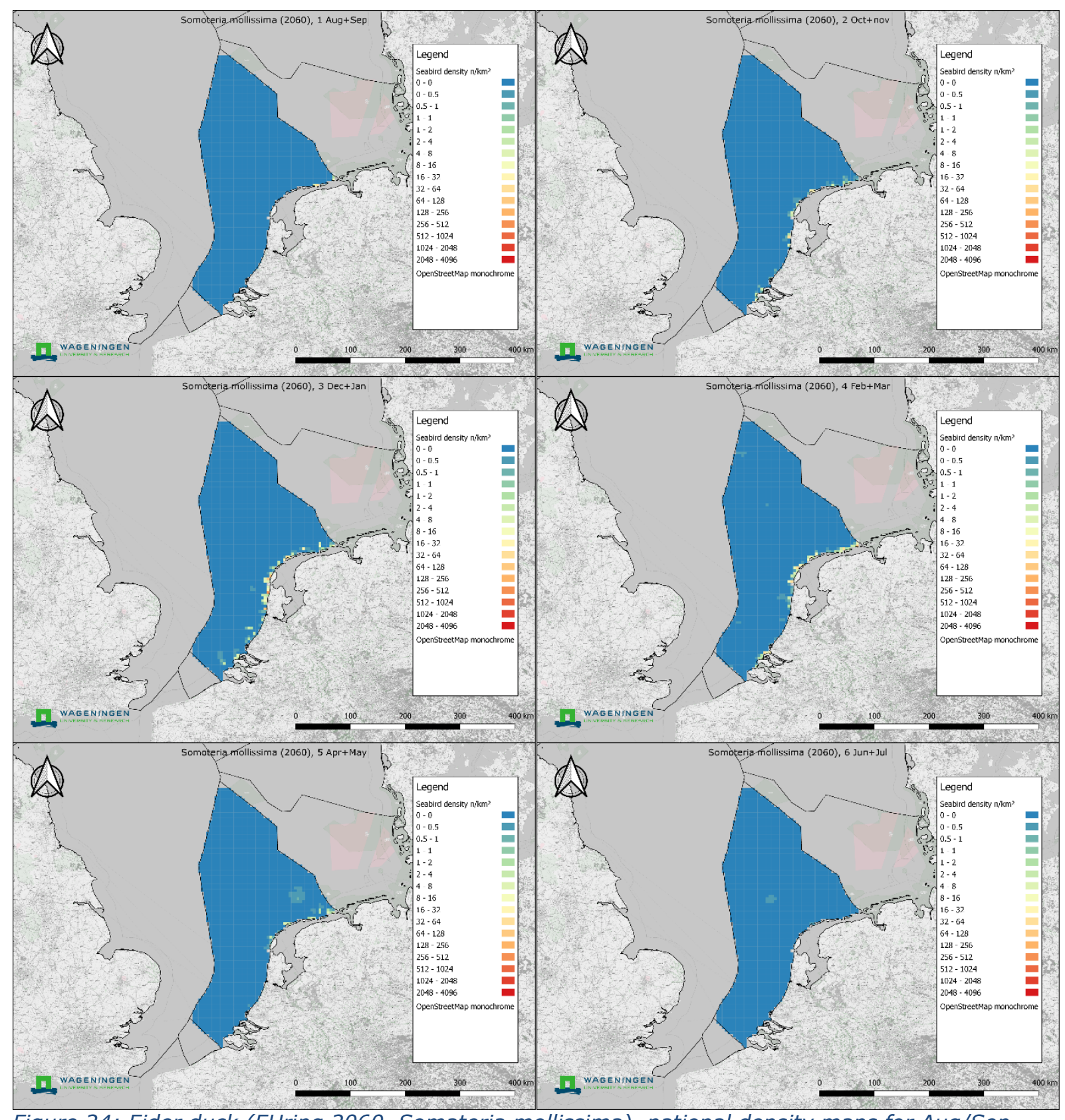

Figure 24: Eider duck (EUring 2060, Somateria mollissima). national density maps for Aug/Sep (top left); Oct/Nov (top right), Dec/Jan (middle left), Feb/Mar (middle right), Apr/May (lower left) and Jun/Jul (lower right). 


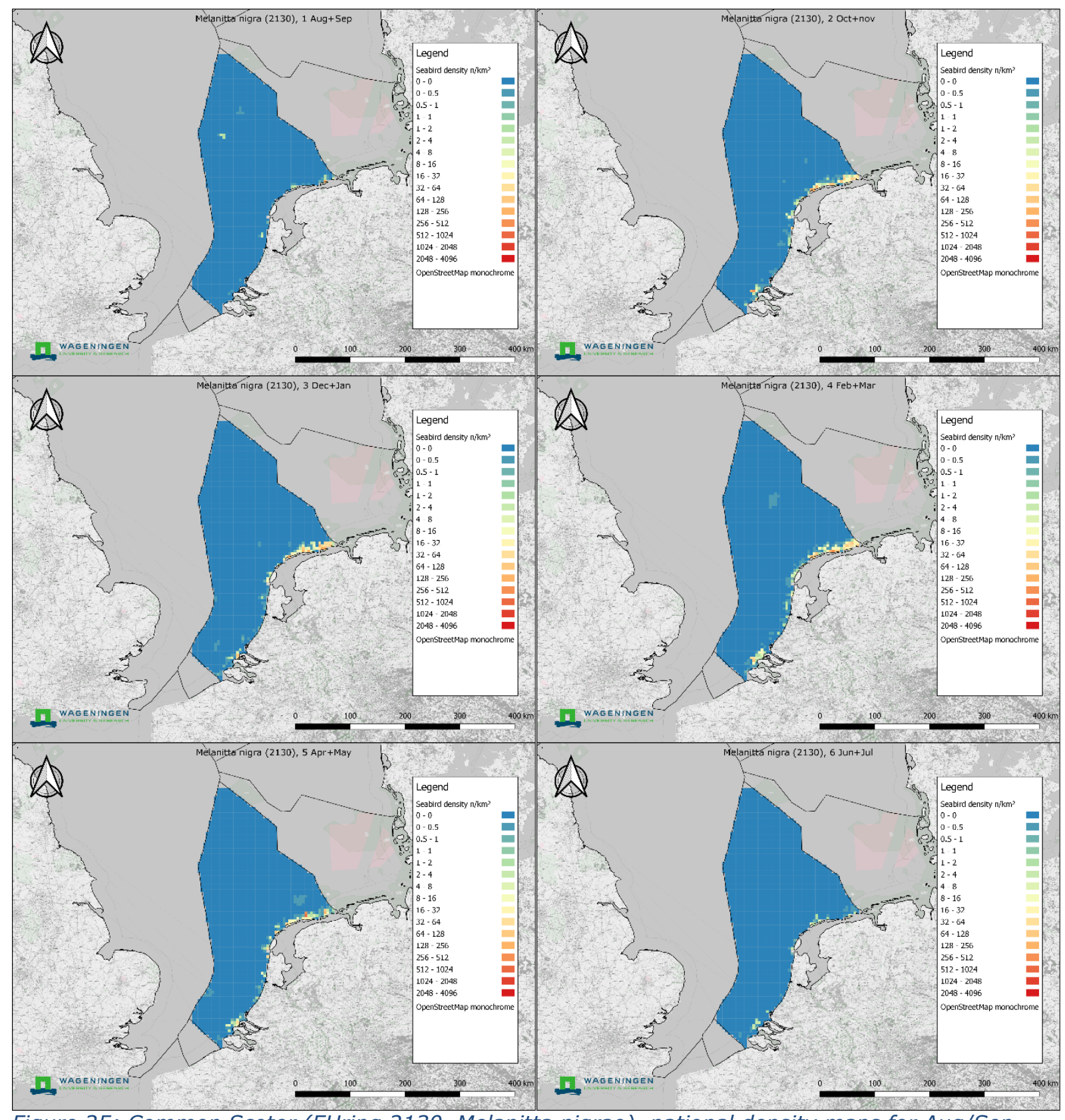

Figure 25: Common Scoter (EUring 2130, Melanitta nigrao). national density maps for Aug/Sep (top left); Oct/Nov (top right), Dec/Jan (middle left), Feb/Mar (middle right), Apr/May (lower left) and Jun/Jul (lower right). 


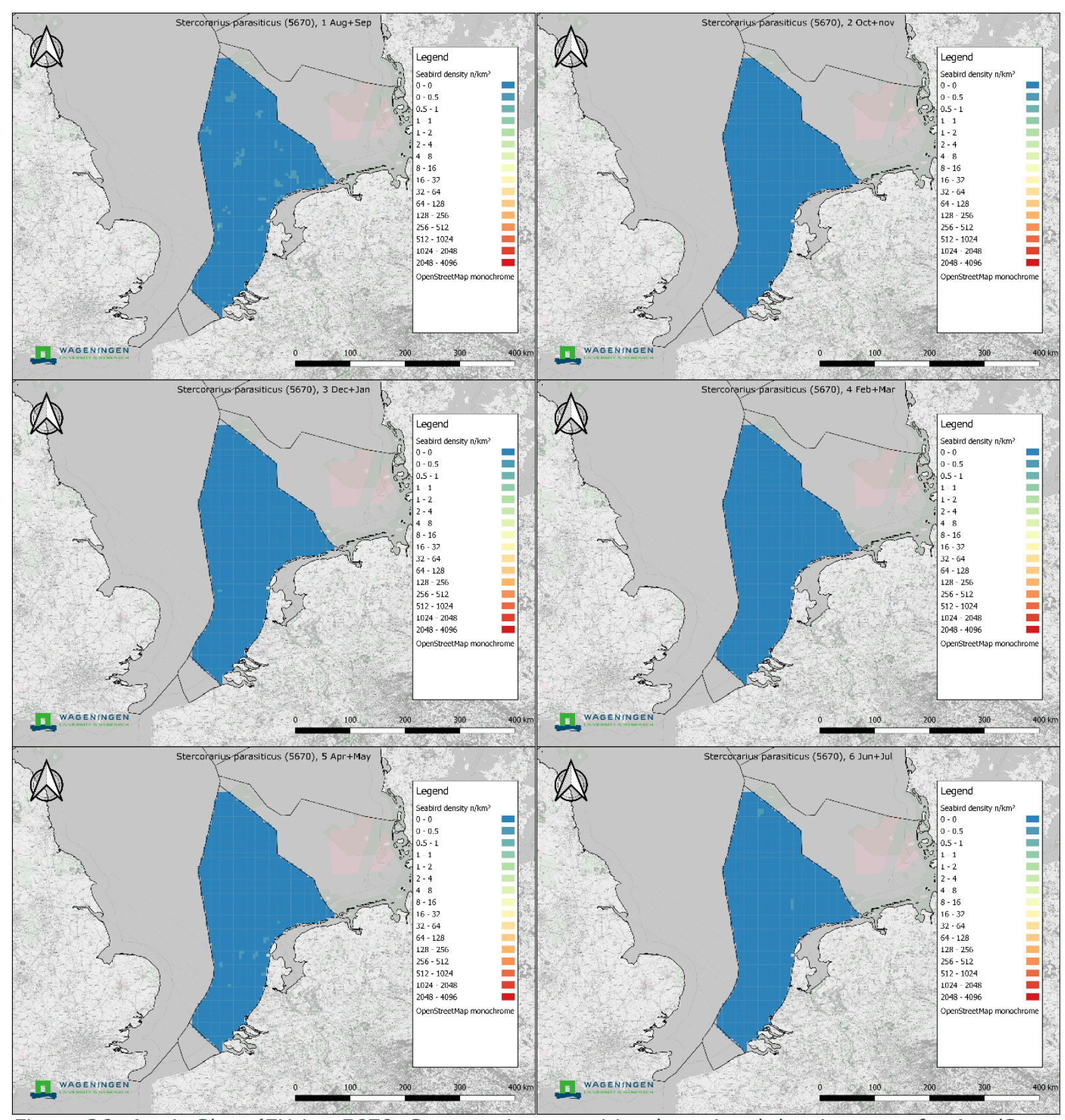

Figure 26: Arctic Skua (EUring 5670, Stercorarius parasiticus). national density maps for Aug/Sep (top left); Oct/Nov (top right), Dec/Jan (middle left), Feb/Mar (middle right), Apr/May (lower left) and Jun/Jul (lower right). 


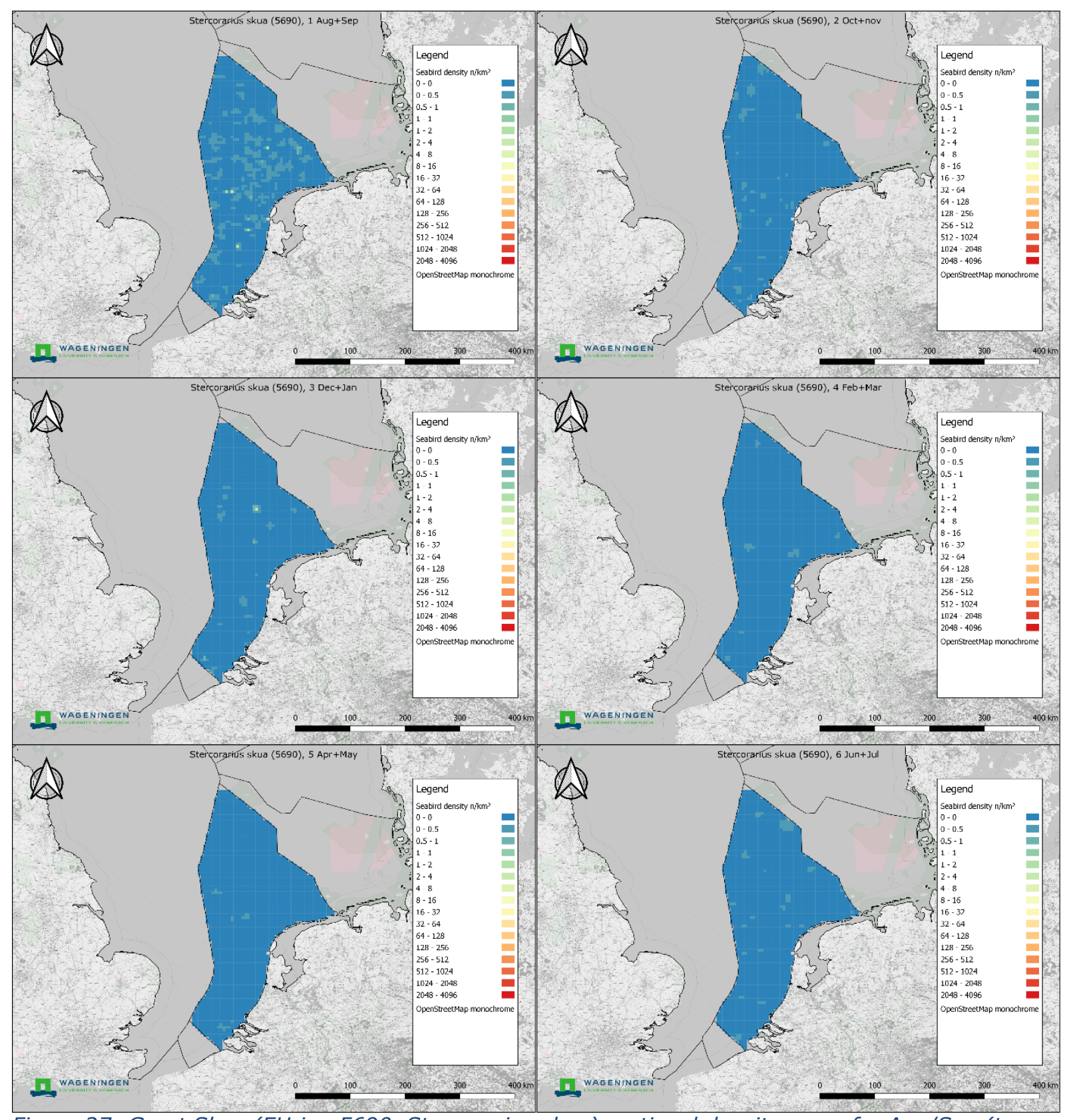

Figure 27: Great Skua (EUring 5690, Stercorarius skua). national density maps for Aug/Sep (top left); Oct/Nov (top right), Dec/Jan (middle left), Feb/Mar (middle right), Apr/May (lower left) and Jun/Jul (lower right). 


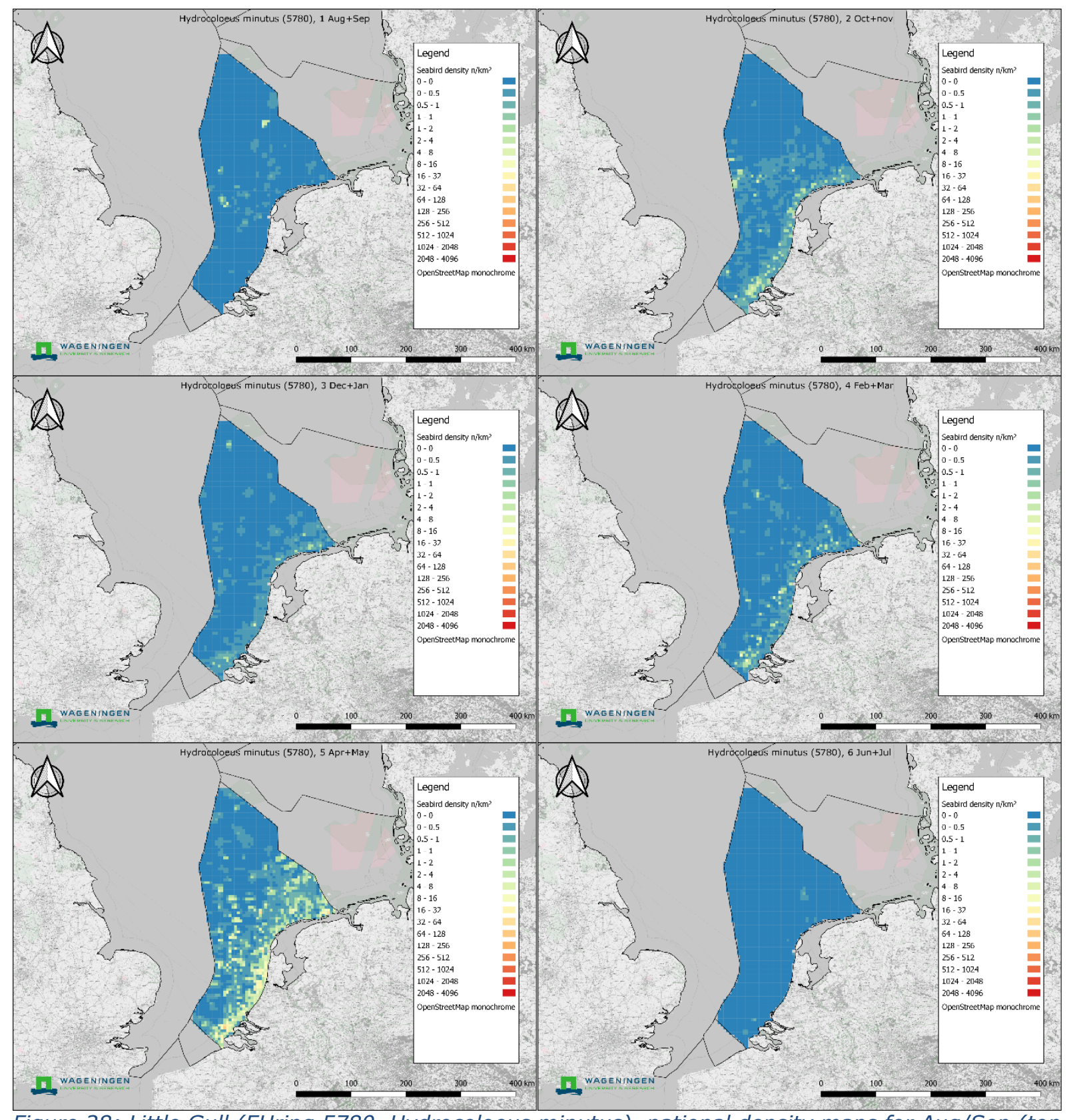

Figure 28: Little Gull (EUring 5780, Hydrocoloeus minutus). national density maps for Aug/Sep (top left); Oct/Nov (top right), Dec/Jan (middle left), Feb/Mar (middle right), Apr/May (lower left) and Jun/Jul (lower right). 


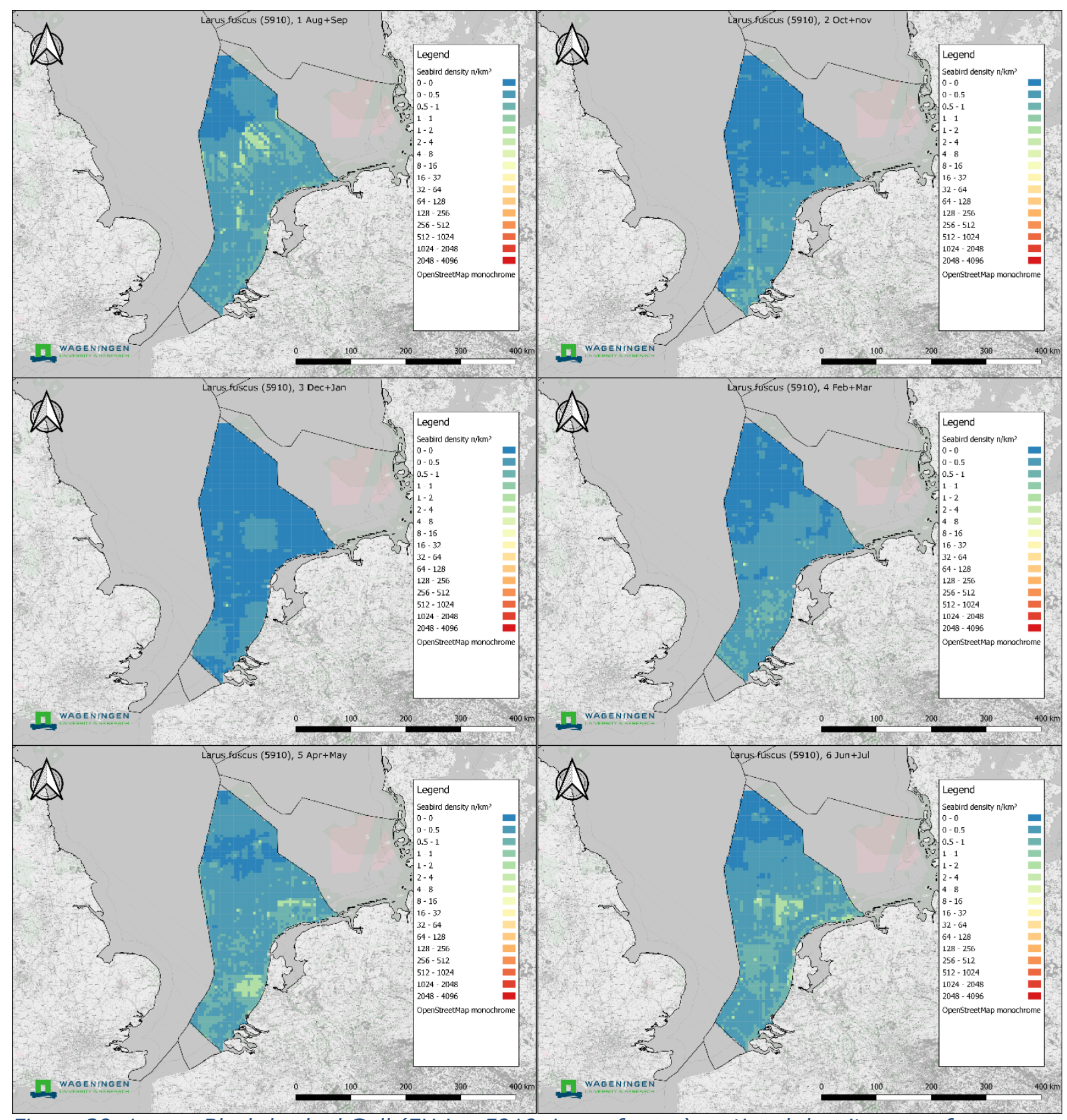

Figure 29: Lesser Black-backed Gull (EUring 5910, Larus fuscus). national density maps for Aug/Sep (top left); Oct/Nov (top right), Dec/Jan (middle left), Feb/Mar (middle right), Apr/May (lower left) and Jun/Jul (lower right). 


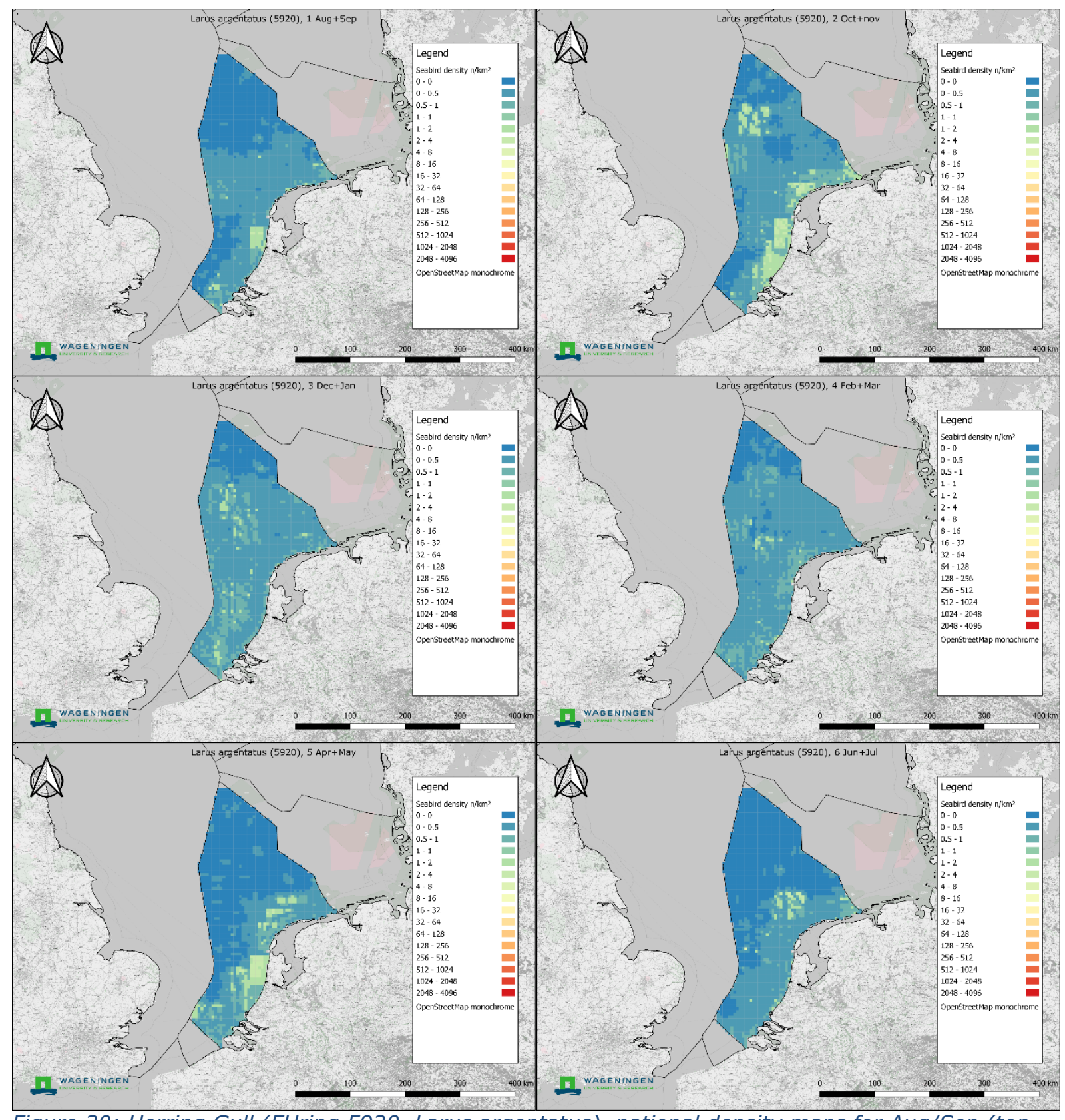

Figure 30: Herring Gull (EUring 5920, Larus argentatus). national density maps for Aug/Sep (top left); Oct/Nov (top right), Dec/Jan (middle left), Feb/Mar (middle right), Apr/May (lower left) and Jun/Jul (lower right). 


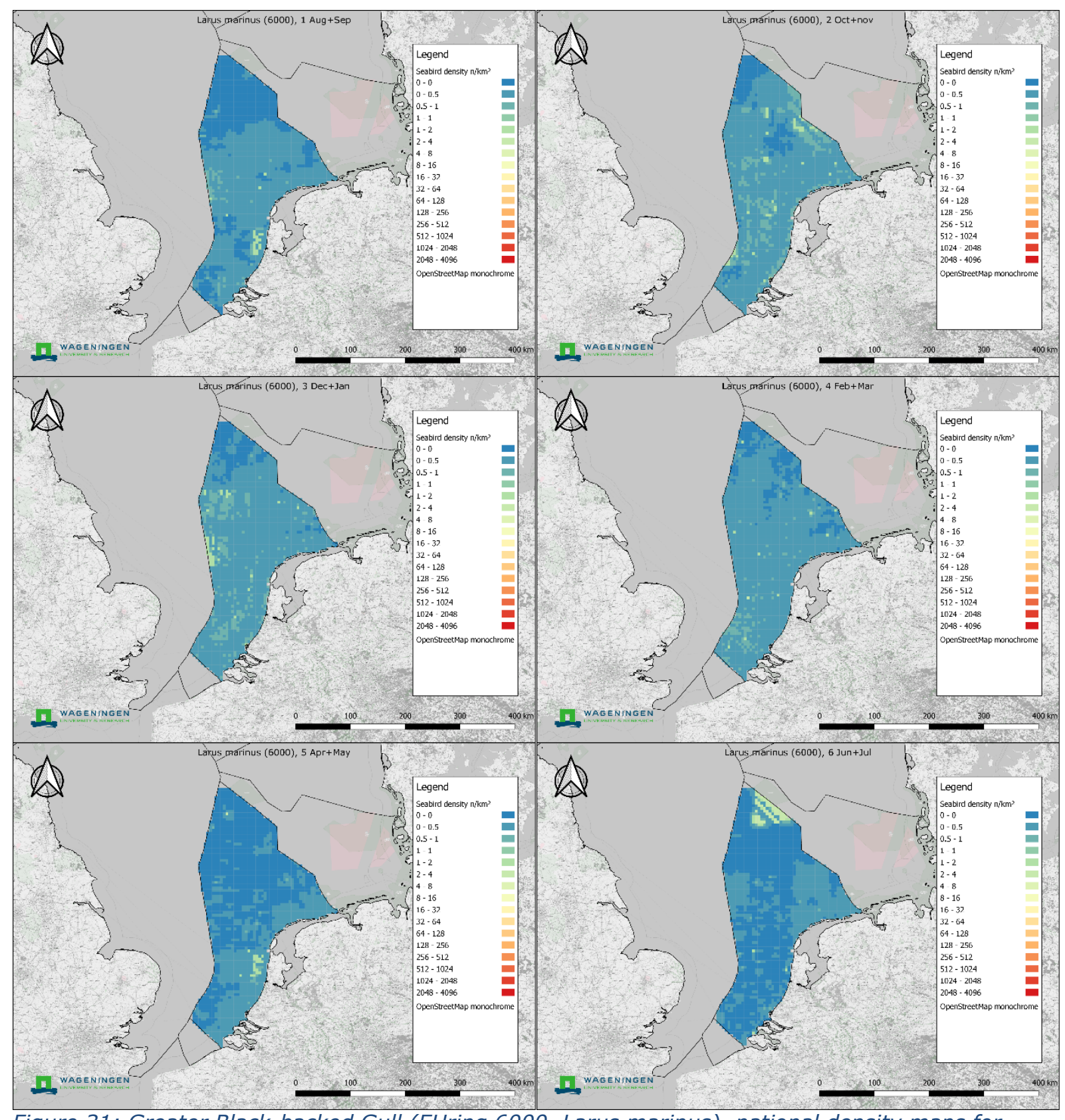

Figure 31: Greater Black-backed Gull (EUring 6000, Larus marinus). national density maps for Aug/Sep (top left); Oct/Nov (top right), Dec/Jan (middle left), Feb/Mar (middle right), Apr/May (lower left) and Jun/Jul (lower right). 


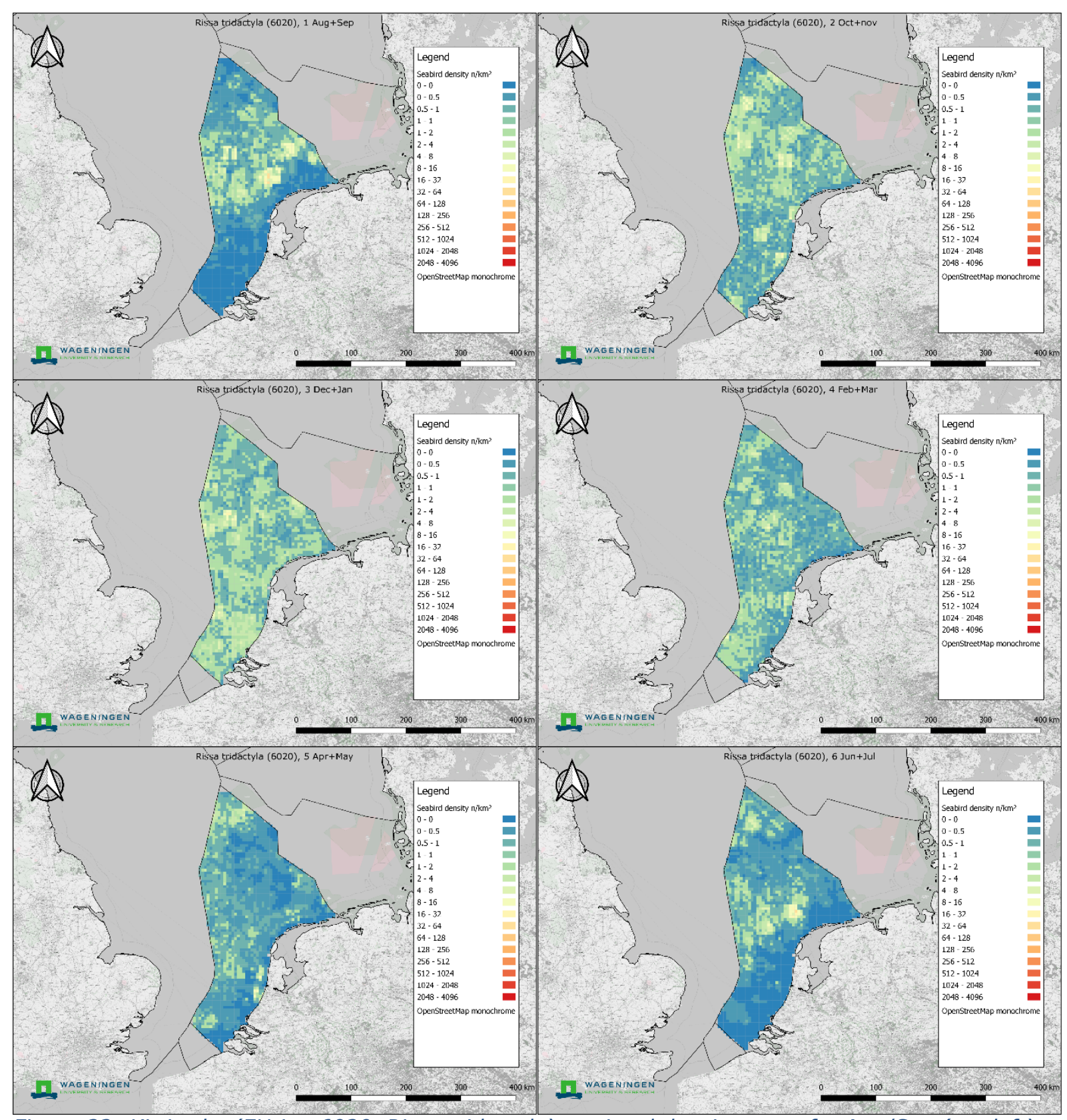

Figure 32: Kittiwake (EUring 6020, Rissa tridactyla). national density maps for Aug/Sep (top left); Oct/Nov (top right), Dec/Jan (middle left), Feb/Mar (middle right), Apr/May (lower left) and Jun/Jul (lower right). 


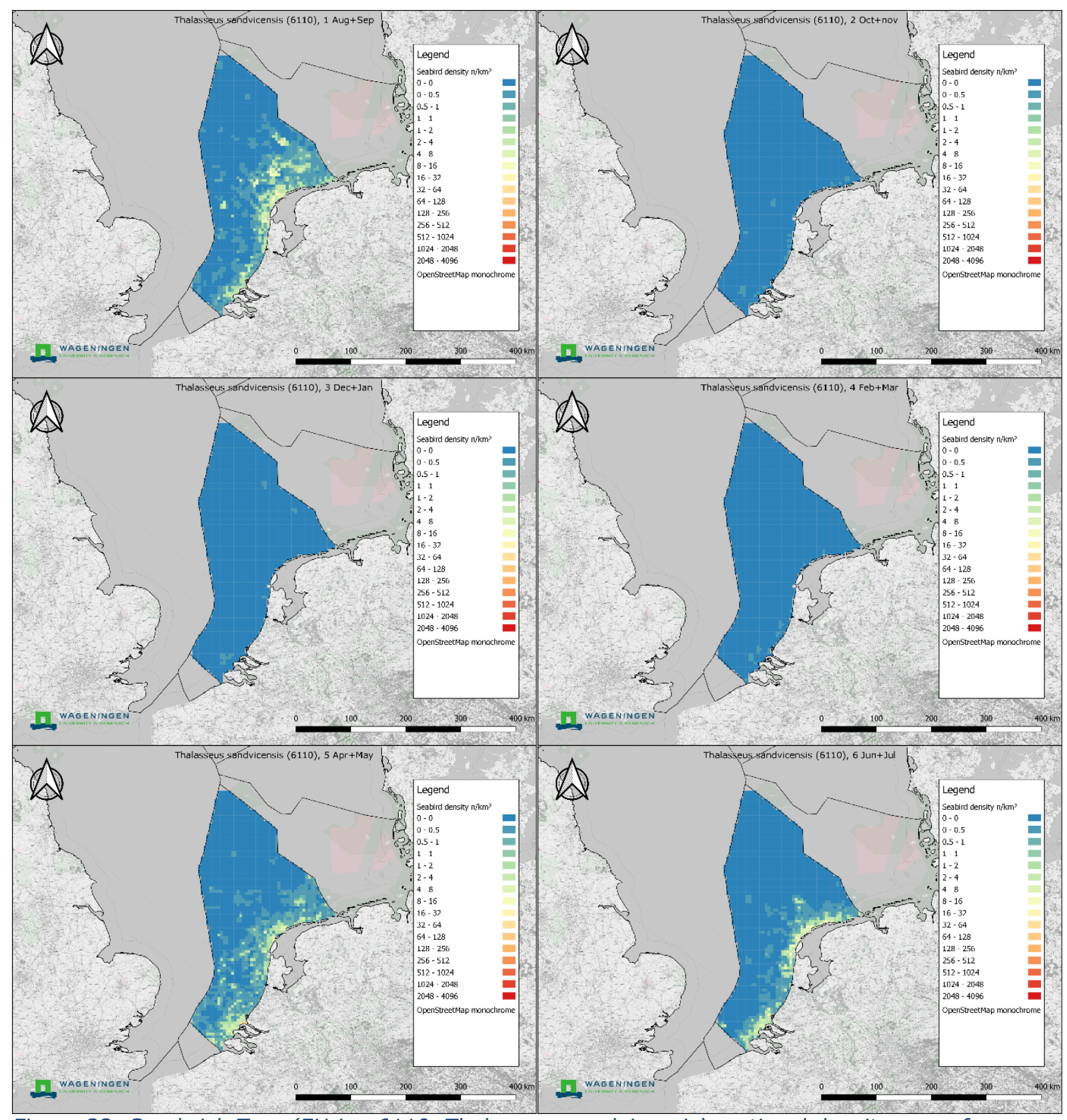

Figure 33: Sandwich Tern (EUring 6110, Thalasseus sandvicensis). national density maps for Aug/Sep (top left); Oct/Nov (top right), Dec/Jan (middle left), Feb/Mar (middle right), Apr/May (lower left) and Jun/Jul (lower right). 


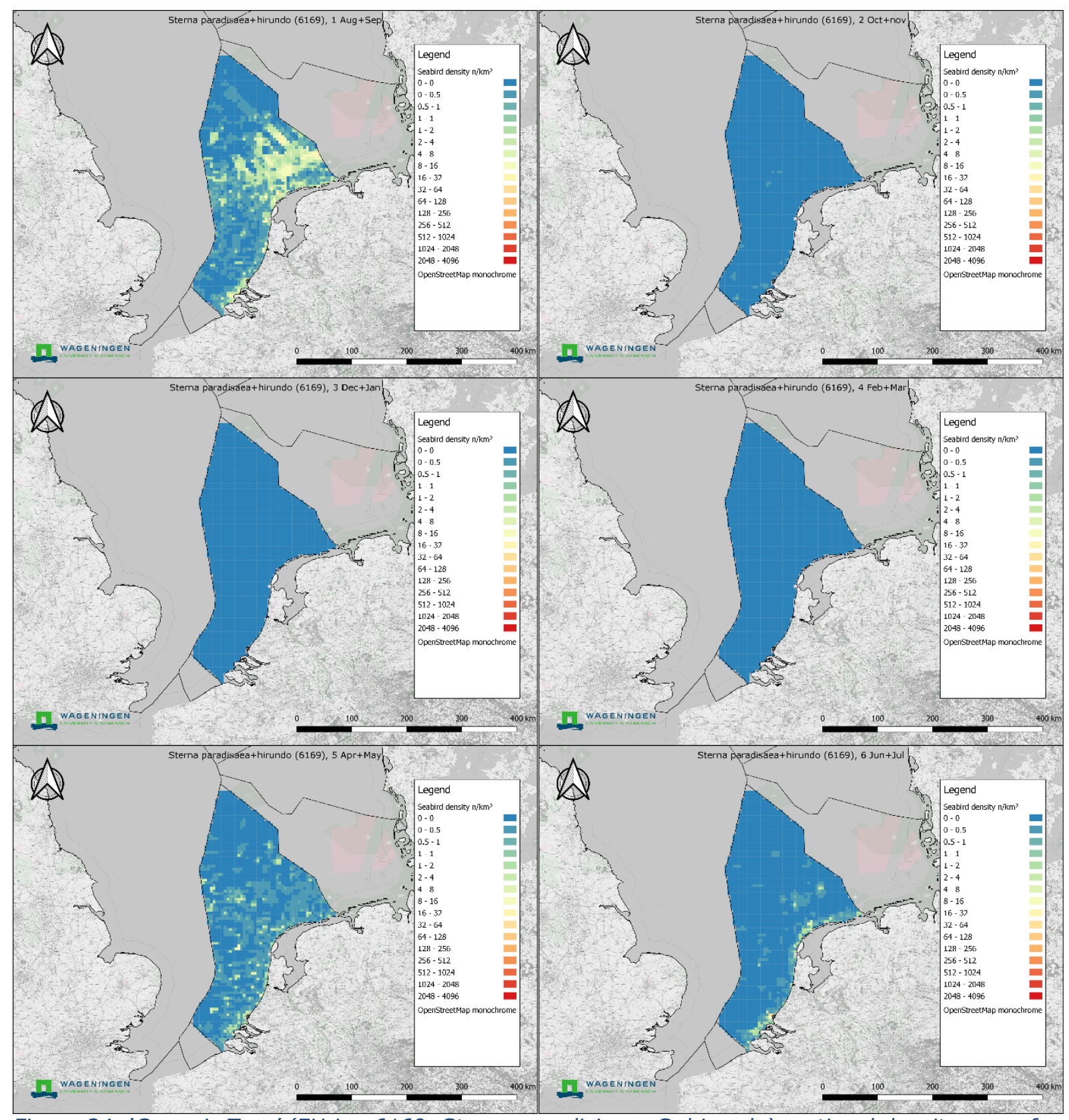

Figure 34: 'Commic Tern' (EUring 6169, Sterna paradisiae + S. hirundo). national density maps for Aug/Sep (top left); Oct/Nov (top right), Dec/Jan (middle left), Feb/Mar (middle right), Apr/May (lower left) and Jun/Jul (lower right). 


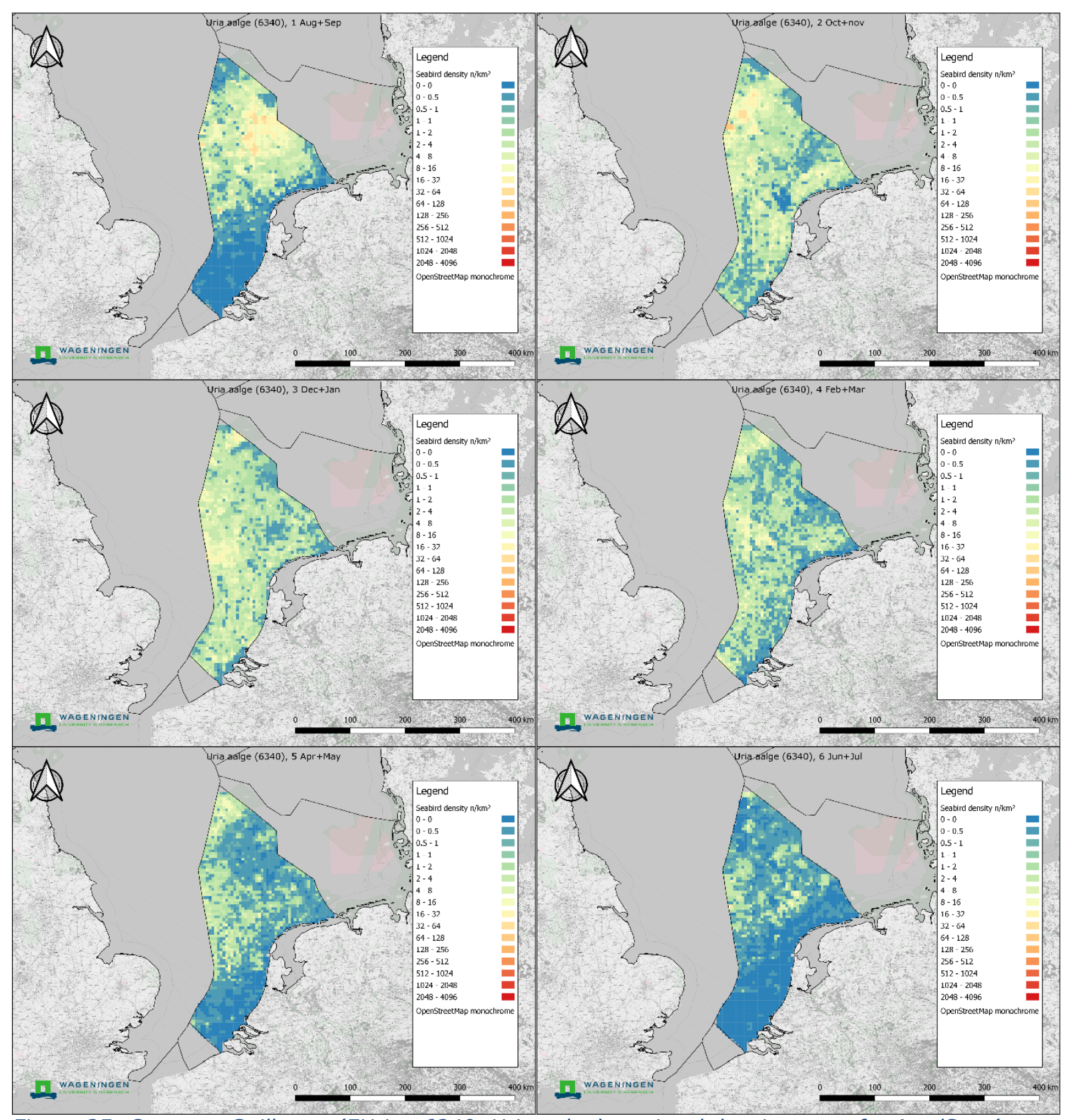

Figure 35: Common Guillemot (EUring 6340, Uria aalge). national density maps for Aug/Sep (top left); Oct/Nov (top right), Dec/Jan (middle left), Feb/Mar (middle right), Apr/May (lower left) and Jun/Jul (lower right). 


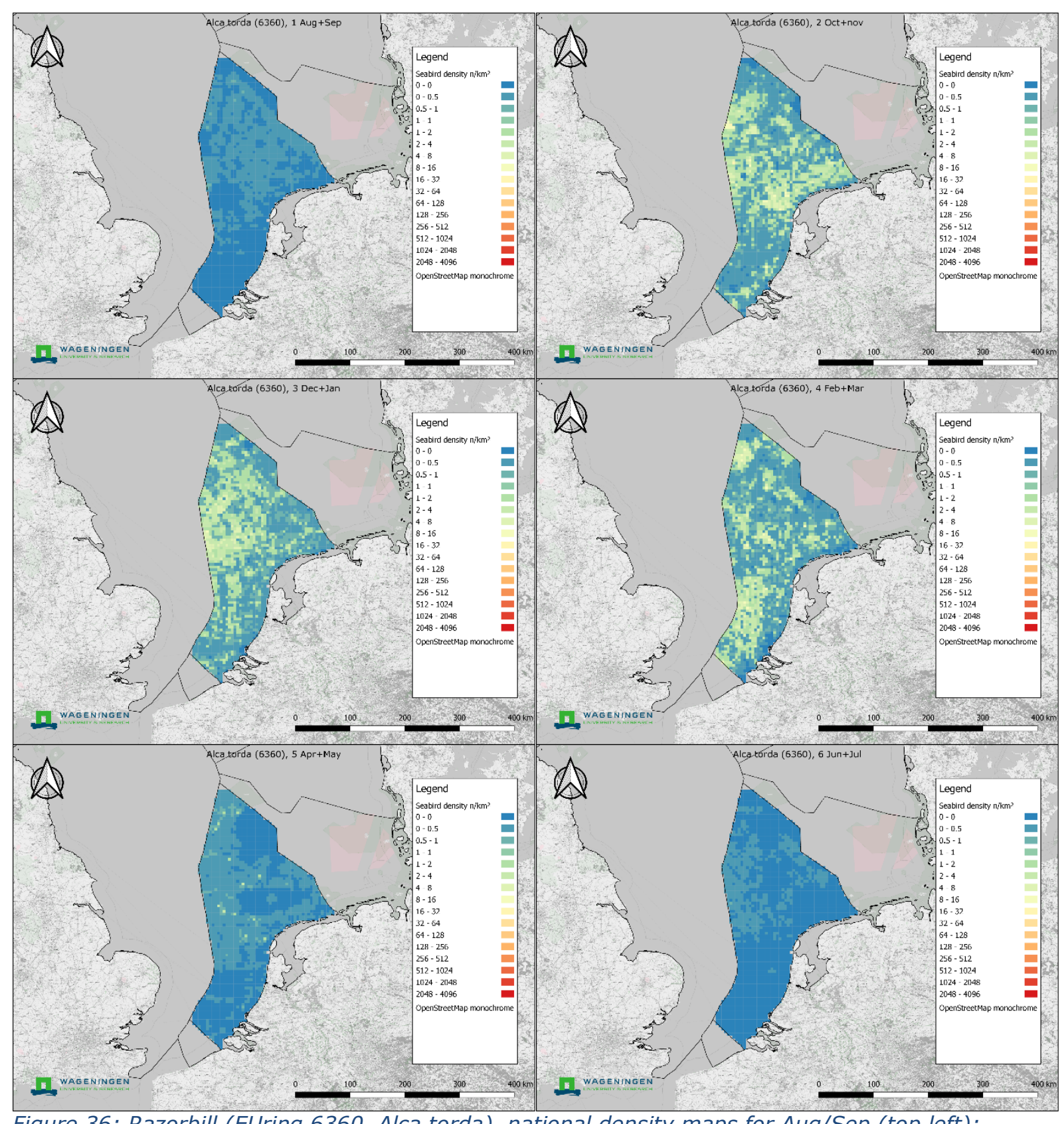

Figure 36: Razorbill (EUring 6360, Alca torda). national density maps for Aug/Sep (top left); Oct/Nov (top right), Dec/Jan (middle left), Feb/Mar (middle right), Apr/May (lower left) and Jun/Jul (lower right). 


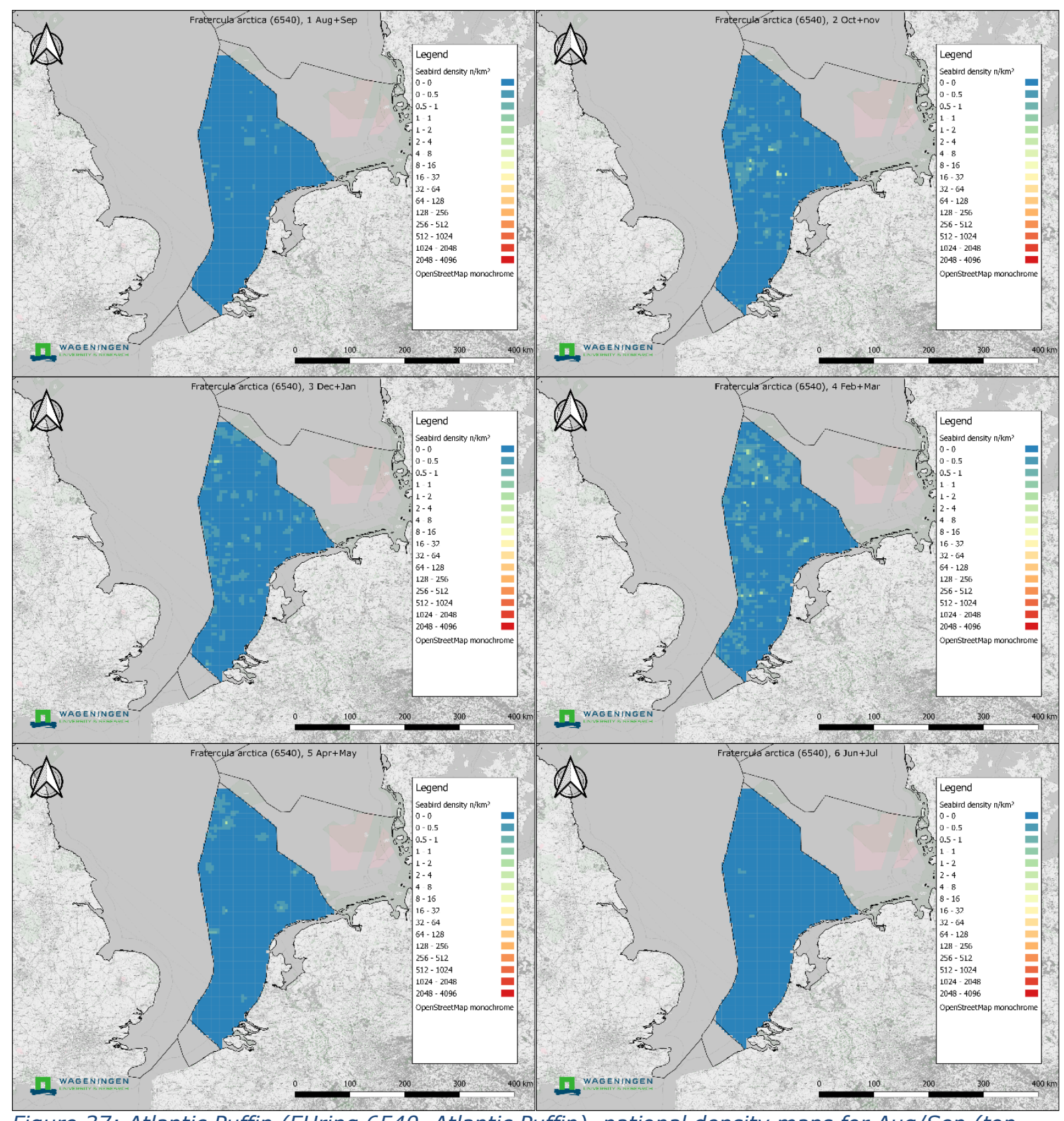

Figure 37: Atlantic Puffin (EUring 6540, Atlantic Puffin). national density maps for Aug/Sep (top left); Oct/Nov (top right), Dec/Jan (middle left), Feb/Mar (middle right), Apr/May (lower left) and Jun/Jul (lower right). 


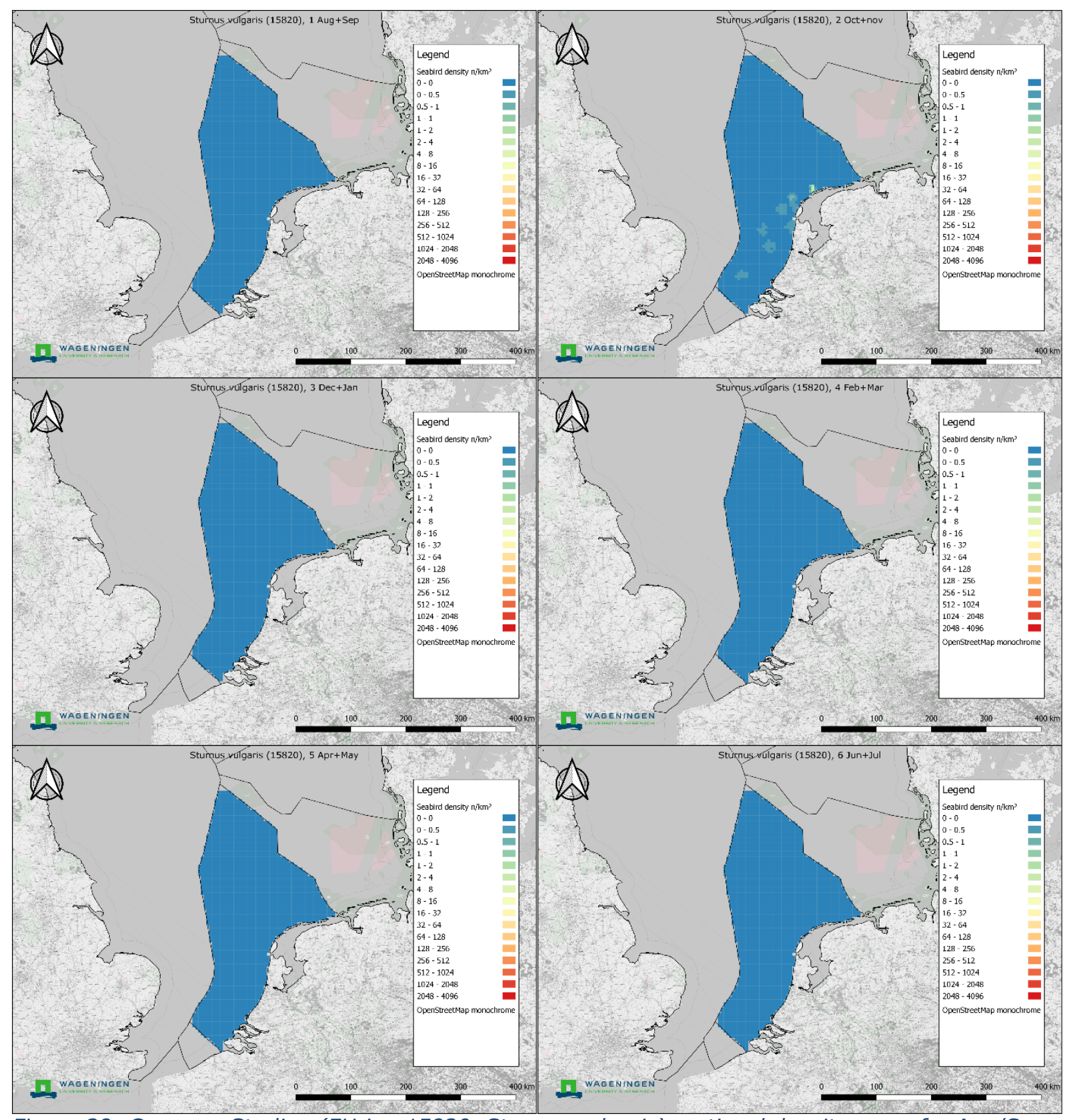

Figure 38: Common Starling (EUring 15820, Sturnus vulgaris). national density maps for Aug/Sep (top left); Oct/Nov (top right), Dec/Jan (middle left), Feb/Mar (middle right), Apr/May (lower left) and Jun/Jul (lower right). 


Fulmarus glacialis

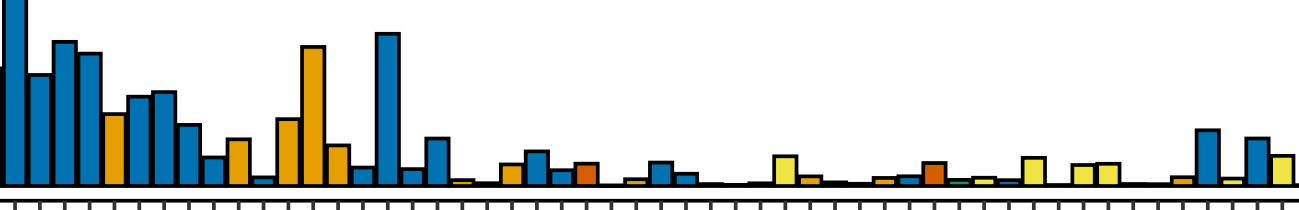

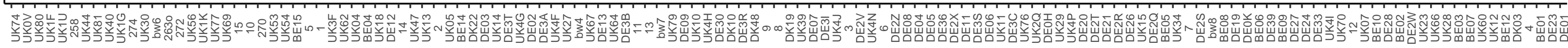

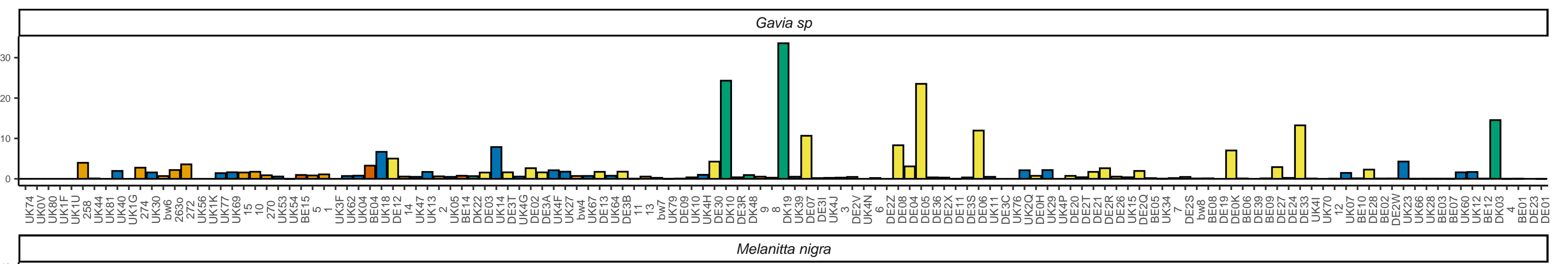

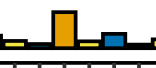

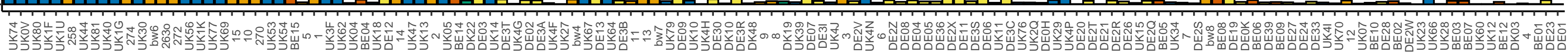
Phalacrocorax carbo

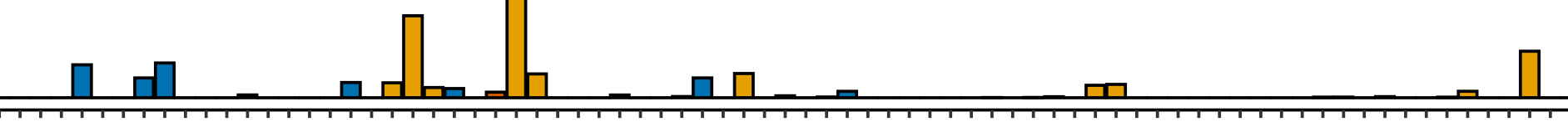

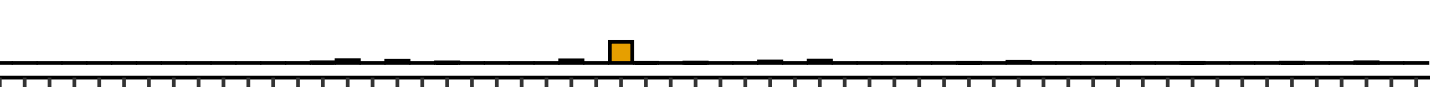

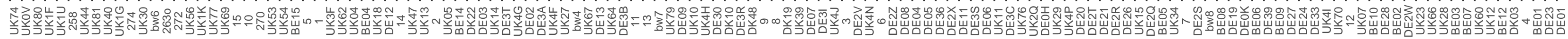
. Somoteria mollissima

\section{1,}

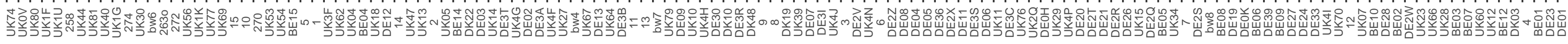
Thalasseus sandvicensis

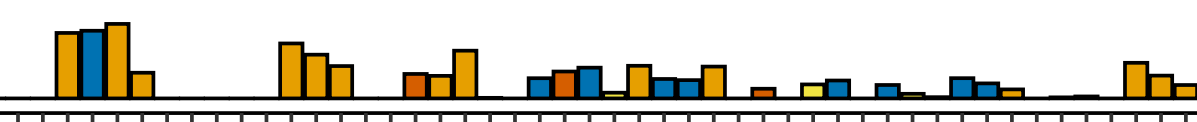

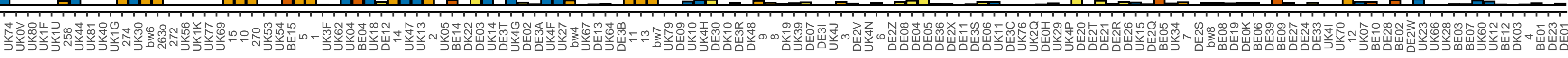
Uria aalge 


\section{Addendum: Yearly average distribution maps for 19 (sea) bird}

\section{species.}

On the following pages for each (sea) bird species a six-panel figure is presented showing from top-left to bottom-right the seasonal distribution for season (bimonth) 1-Aug/Sep; 2-Oct/Not; 3-Dec/Jan; 4Feb/Mar; 5-Apr/May and 6-Jun/Jul.

The first set is for the International maps for the study area as it overlaps with the EEZs of the following countries: Belgium, United Kingdom, Norway, Denmark, Germany and the Netherlands (Fig 1 thru Fig 18), The second set is for the National Maps, coinciding with the Dutch EEZ (aka NCP for Nederlands Continentaal Plat) (Fig 19 thru Fig 38).

In both cases the species are presented in order of increasing EUring-code as per the table below:

\begin{tabular}{r|lll} 
EURING & SCIENTIFIC NAME & NL NAME & EN NAME \\
\hline $\mathbf{5 9}$ & Gavia sp & Duiker spec. & Diver sp \\
$\mathbf{2 2 0}$ & Fulmarus glacialis & Noordse Stormvogel & Northern Fulmar \\
$\mathbf{7 1 0}$ & Morus bassanus & Jan-van-Gent & Gannet \\
$\mathbf{7 2 0}$ & Phalacrocorax carbo & Aalscholver & Cormorant \\
$\mathbf{2 0 6 0}$ & Somateria mollissima & Eidereend & Eider duck \\
$\mathbf{2 1 3 0}$ & Melanitta nigra & Zw. Zeeëend & Common Scoter \\
$\mathbf{5 6 7 0}$ & Stercorarius parasiticus & Kleine Jager & Arctic Skua \\
$\mathbf{5 6 9 0}$ & Stercorarius skua & Grote Jager & Great Skua \\
$\mathbf{5 7 8 0}$ & Hydrocoloeus minutus & Dwergmeeuw & Little Gull \\
$\mathbf{5 9 1 0}$ & Larus fuscus & Kleine Mantelmeeuw & Lesser black-backed Gull \\
$\mathbf{5 9 2 0}$ & Larus argentatus & Zilvermeeuw & Herring Gull \\
$\mathbf{6 0 0 0}$ & Larus marinus & Grote Mantelmeeuw & Great Black-backed Gull \\
$\mathbf{6 0 2 0}$ & Rissa tridactyla & Drieeteenmeeuw & Kittiwake \\
$\mathbf{6 1 1 0}$ & Thalasseus sandvicensis & Grote Stern & Sandwich Tern \\
$\mathbf{6 1 6 9}$ & Sterna paradisaea+hirundo & "Noordse Dief" & "Commic Tern" \\
$\mathbf{6 3 4 0}$ & Uria aalge & Zeekoet & Common Guillemot \\
$\mathbf{6 3 6 0}$ & Alca torda & Alk & Razorbill \\
$\mathbf{6 5 4 0}$ & Fratercula arctica & Papegaaiduiker & Atlantic Puffin \\
$\mathbf{1 5 8 2 0}$ & Sturnus vulgaris & Spreeuw & Common Starling
\end{tabular}




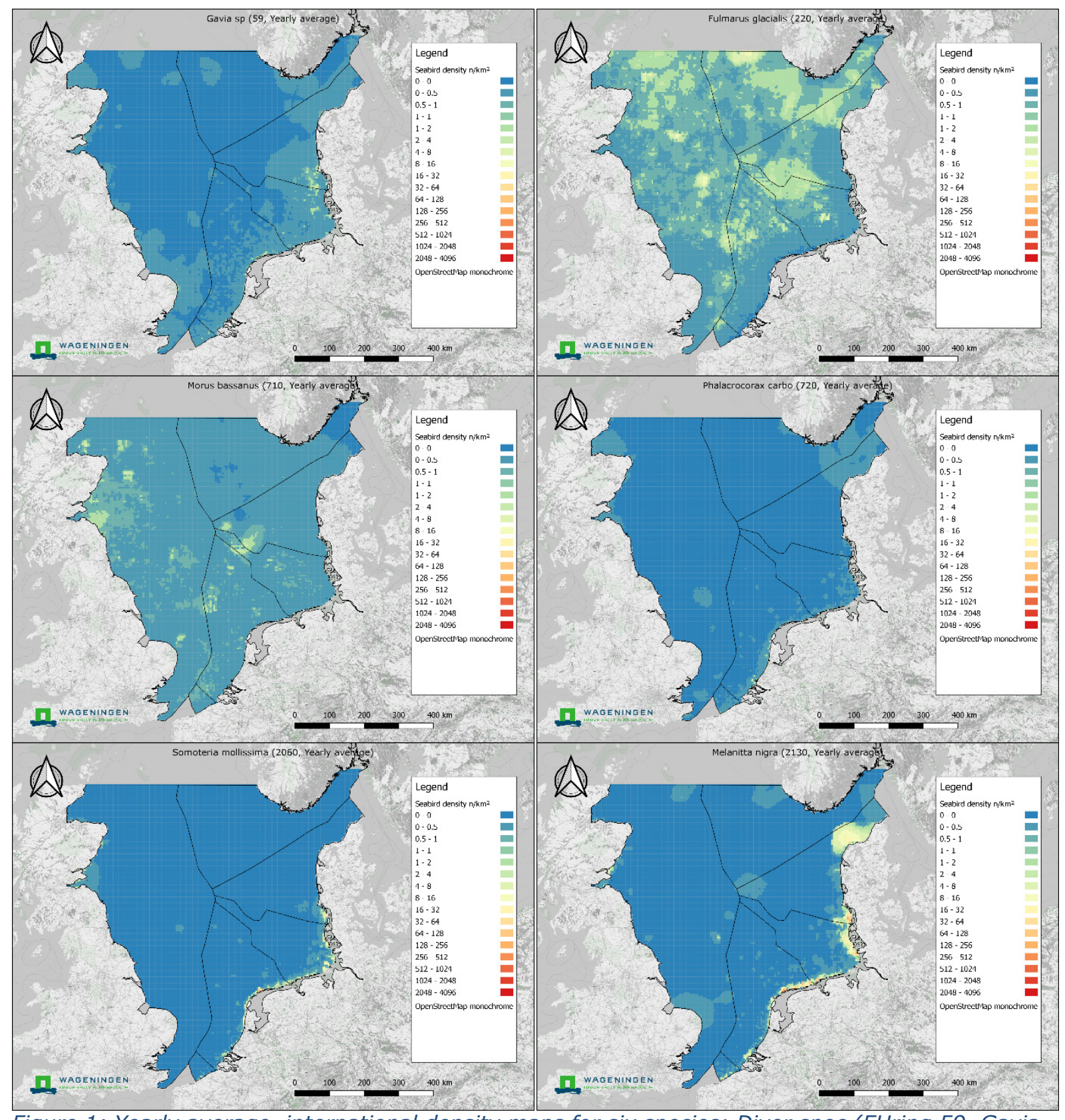

Figure 1: Yearly average, international density maps for six species: Diver spec (EUring 59, Gavia spec) (top left); Northern Fulmar (EUring 220, Fulmarus glacialis) (top right), Gannet (EUring 710, Morus bassanus) (middle left), Cormorant (EUring 720), Phalacrocorax carbo) (middle right), Eider duck (Euring 2060, Somateria mollissima) (lower left) and Common Scoter (EUring 2130, Melanitta nigra) (lower right). 


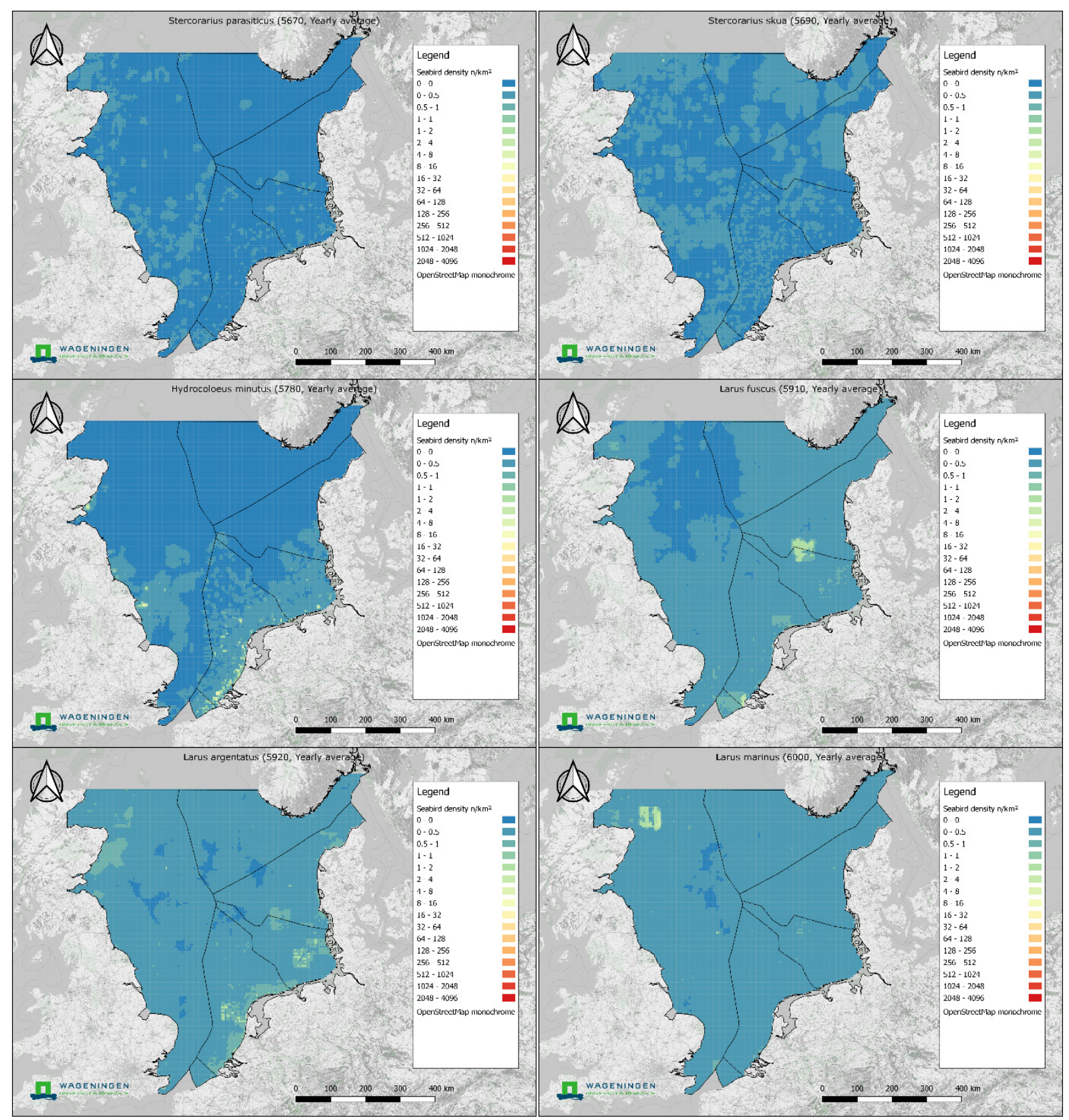

Figure 2: Yearly average, internationial density maps for six species: Arctic Skua (EUring 5670 Stercorarius parasiticus) (top left); Great Skua (EUring 5690, Stercorarius skua) (top right), Little Gull (EUring 5780, Hydrocoloeus minutus) (middle left), Lesser Black-back Gull (EUring 5910, Larus fuscus) (middle right), Herring Gull (Euring 5920, Larus argentatus) (lower left) and Greater Black-backed Gull (EUring 6000, Larus marinus) (lower right). 


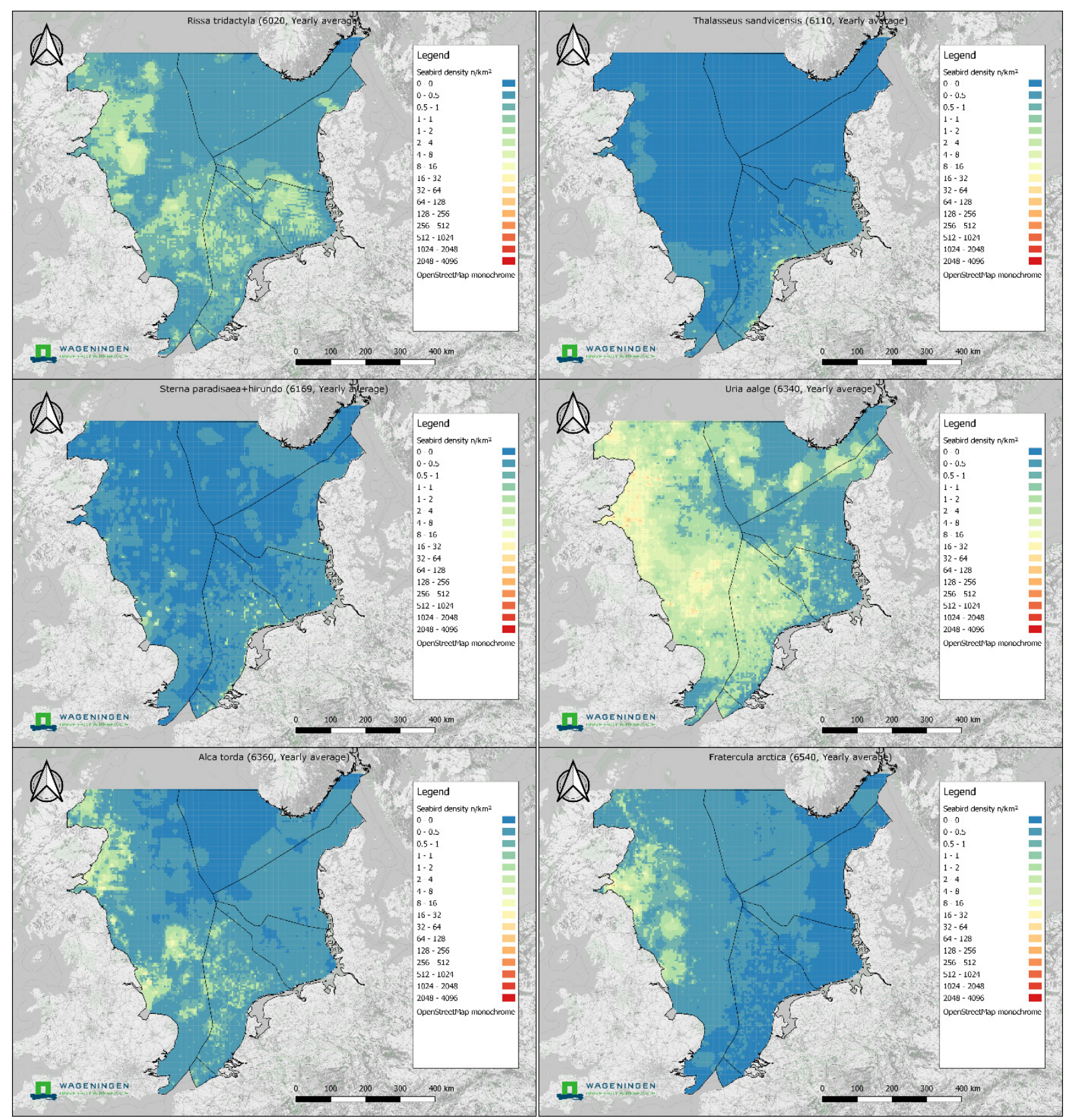

Figure 3: Yearly average, international density maps for six species: Kittiwake (EUring 6020, Rissa tridactyla) (top left); Sandwich Tern (EUring 6110, Thalasseus sandvicensis) (top right), 'Commic Tern' (EUring 6169, Sterna paradiseae + S. hirundao) (middle left), Common Guillemot (EUring 6340, Uria aalge) (middle right), Razorbill (Euring 6360, Alca torda) (lower left) and Atlantic Puffin (EUring 6540, Fratercula arctica) (lower right). 


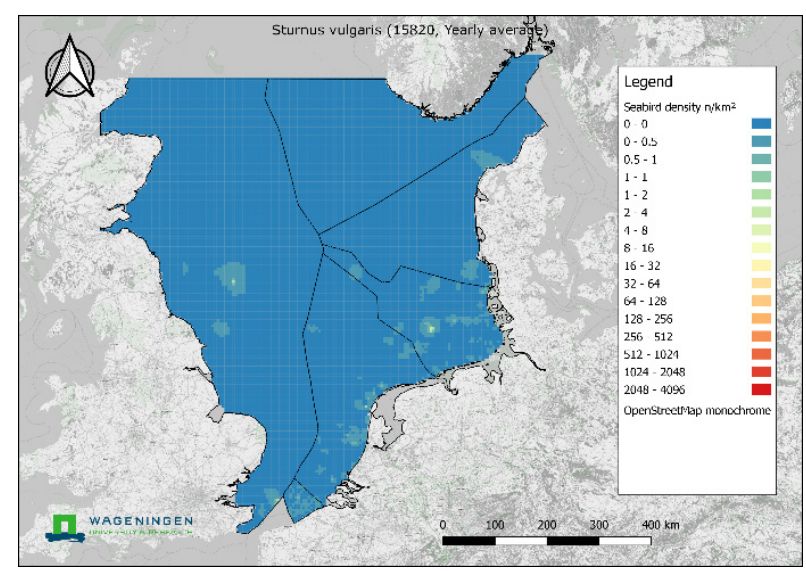

Figure 4: Yearly average, international density map for one species: Common Starling (EUring 15820, Sturnus vulgaris) (top left). 


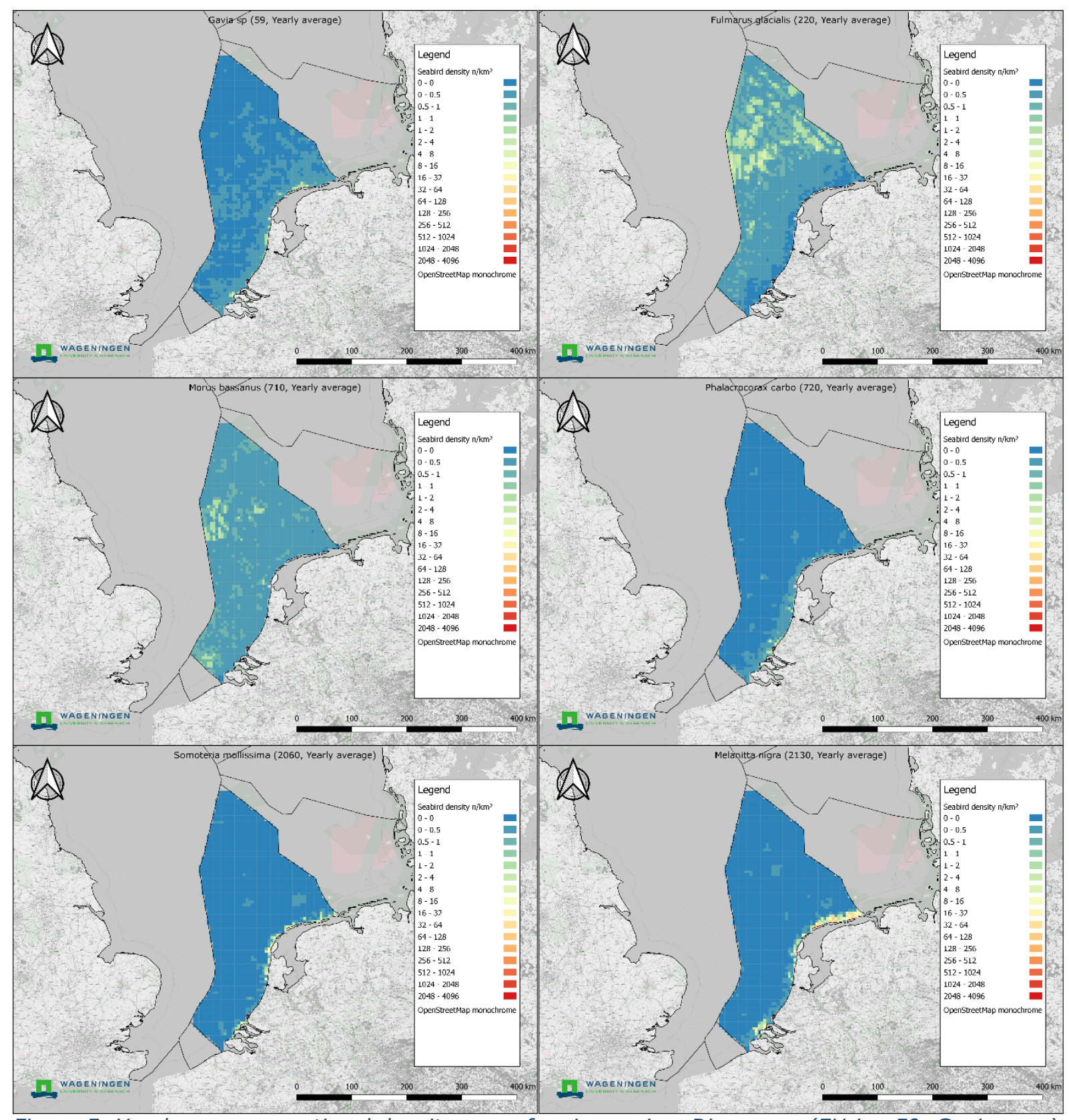

Figure 5: Yearly average, national density maps for six species: Diver spec (EUring 59, Gavia spec) (top left); Northern Fulmar (EUring 220, Fulmarus glacialis) (top right), Gannet (EUring 710, Morus bassanus) (middle left), Cormorant (EUring 720), Phalacrocorax carbo) (middle right), Eider duck (Euring 2060, Somateria mollissima) (lower left) and Common Scoter (EUring 2130, Melanitta nigra) (lower right). 


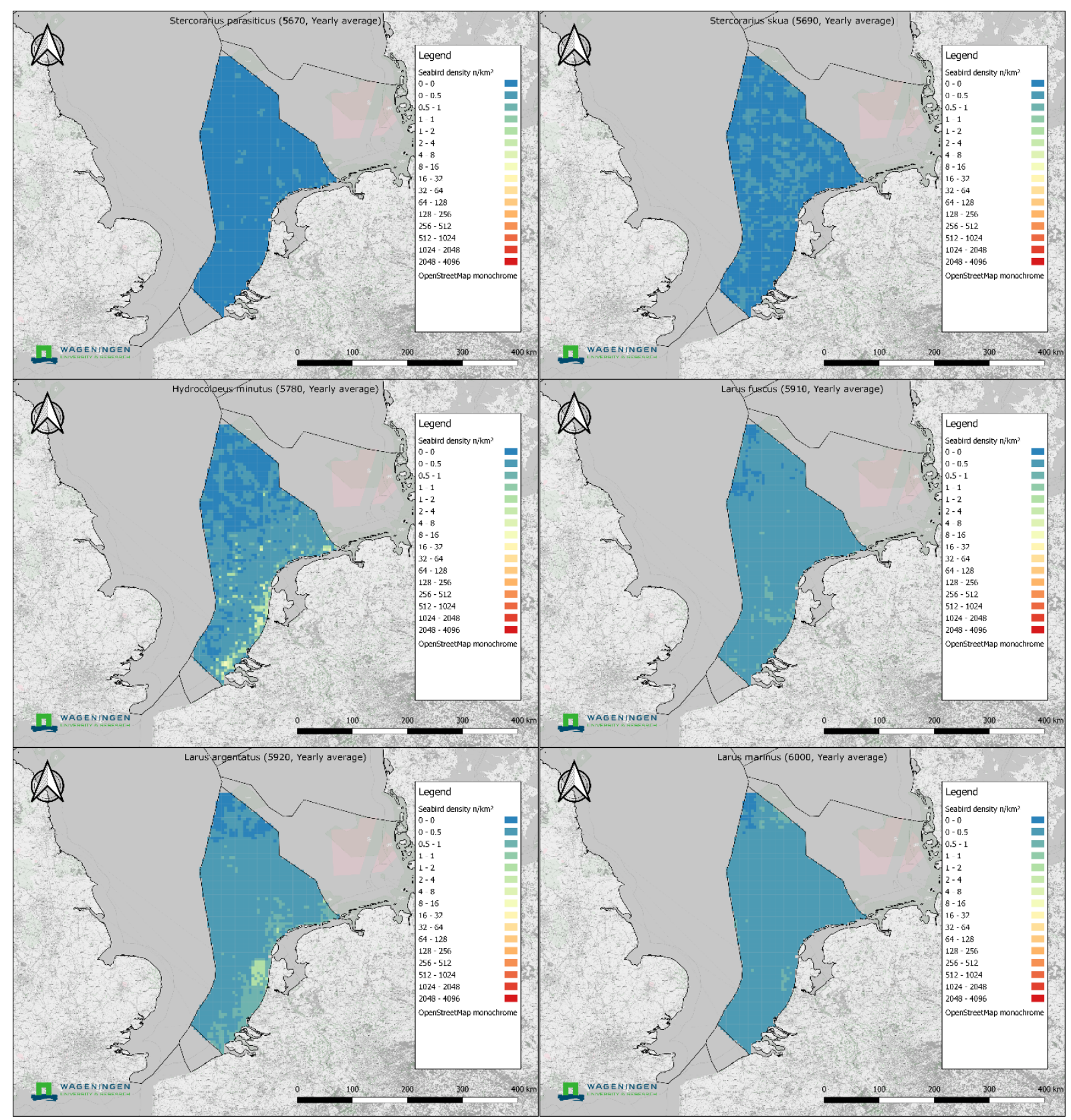

Figure 6: Yearly average, nationial density maps for six species: Arctic Skua (EUring 5670

Stercorarius parasiticus) (top left); Great Skua (EUring 5690, Stercorarius skua) (top right), Little Gull (EUring 5780, Hydrocoloeus minutus) (middle left), Lesser Black-back Gull (EUring 5910,

Larus fuscus) (middle right), Herring Gull (Euring 5920, Larus argentatus) (lower left) and Greater Black-backed Gull (EUring 6000, Larus marinus) (lower right). 


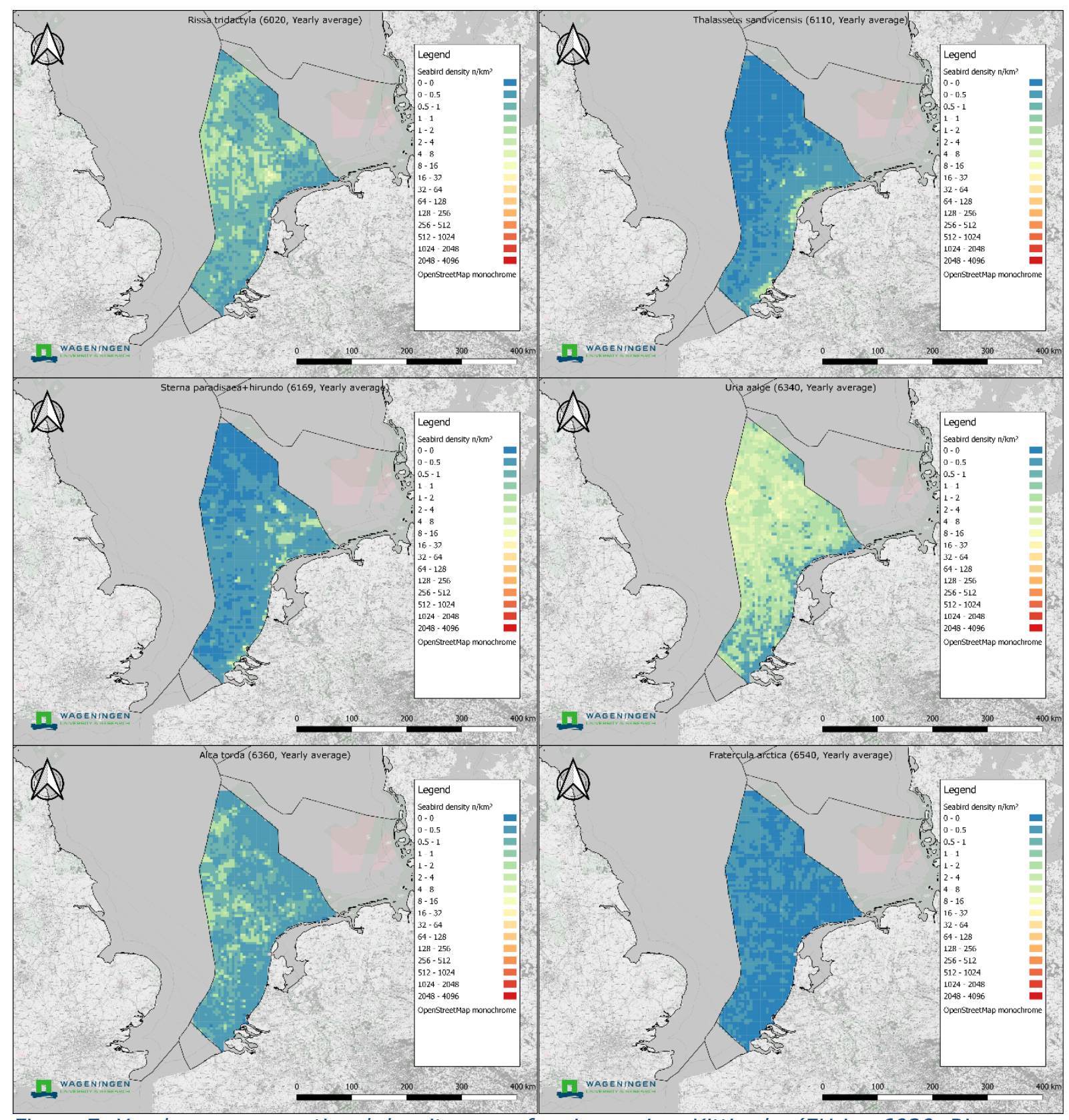

Figure 7: Yearly average, national density maps for six species: Kittiwake (EUring 6020, Rissa tridactyla) (top left); Sandwich Tern (EUring 6110, Thalasseus sandvicensis) (top right), 'Commic Tern' (EUring 6169, Sterna paradiseae + S. hirundao) (middle left), Common Guillemot (EUring 6340, Uria aalge) (middle right), Razorbill (Euring 6360, Alca torda) (lower left) and Atlantic Puffin (EUring 6540, Fratercula arctica) (lower right). 


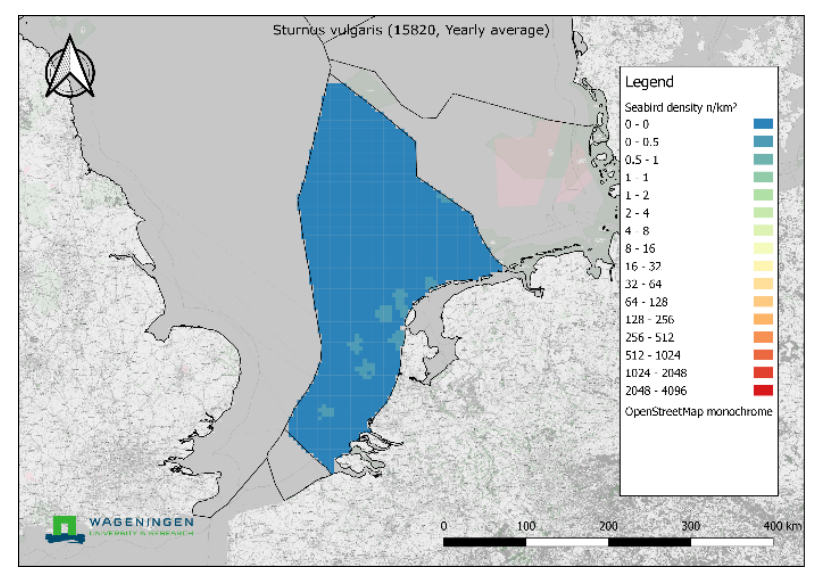

Figure 8: Yearly average, national density map for one species: Common Starling (EUring 15820, Sturnus vulgaris) (top left). 